VILNIAUS GEDIMINO TECHNIKOS UNIVERSITETAS

Michail BERBA

\title{
PASYVIỤJU ŽEMOJO DAŽNIO VIRPESIŲ IZOLIAVIMO SISTEMŲ TYRIMAS
}

\section{DAKTARO DISERTACIJA}

TECHNOLOGIJOS MOKSLAI, MECHANIKOS INŽINERIJA (09T) 
Disertacija rengta 2009-2012 metais Vilniaus Gedimino technikos universitete

\section{Mokslinis vadovas}

doc. dr. Mindaugas JUREVIČIUS (Vilniaus Gedimino technikos universitetas, technologijos mokslai, mechanikos inžinerija - 09T).

VGTU leidyklos TECHNIKA 2060-M mokslo literatūros knyga http://leidykla.vgtu.lt

ISBN 978-609-457-358-3

(C) VGTU leidykla TECHNIKA, 2012

(C) Michail Berba, 2012

info@standa.lt 
VILNIUS GEDIMINAS TECHNICAL UNIVERSITY

Michail BERBA

\section{RESEARCH OF PASSIVE \\ LOW-FREQUENCY VIBRATION ISOLATION SYSTEMS}

DOCTORAL DISSERTATION

TECHNOLOGICAL SCIENCES,

MECHANICAL ENGINEERING (09T)

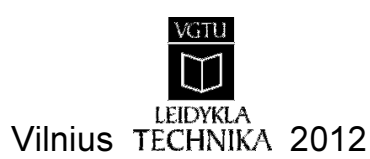


Doctoral dissertation was prepared at Vilnius Gediminas Technical University in 2009-2012.

\section{Scientific Supervisor}

Assoc Prof Dr Mindaugas JUREVIČIUS (Vilnius Gediminas Technical University, Technological Sciences, Mechanical Engineering - 09T). 


\section{Reziumè}

Disertacijoje nagrinejjamas naujai sukurtų mechaninių pasyviujų žemojo $(0,7-50 \mathrm{~Hz})$ dažnio virpesių izoliavimo sistemų dinaminių charakteristikų nustatymas. Pateikiami teoriniai ir eksperimentiniai tyrimai.

Pagrindinis disertacijos tikslas - sukurti mechaninių pasyviujjų žemojo dažnio virpesių izoliavimo sistemų dinaminiu parametrų nustatymo metodiką ir kvazinulinio standžio virpesių izoliavimo sistema, ištirti dinamines jų charakteristikas ir naudojimo galimybes. Tyrimų objektas - žemojo dažnio pasyviosios virpesių izoliavimo mechaninès sistemos ir jų dinaminių charakteristikų nustatymas.

Siekiant igyvendinti tyrimų tikslą, išspręsti šie uždaviniai: 1) atlikta mokslinès literatūros apie pasyviujų ir aktyviujų virpesių izoliavimo sistemų tipus, konstrukcijas, veikimo principus analizė; 2) išanalizuoti ir pagrįsti mechaninių pasyviujų virpesių izoliavimo sistemų dinaminių charakteristikų nustatymo metodai; 3) sukurtas kvazinulinio standžio virpesių izoliavimo metodas ir sistema, pagrịsta spyruoklių standžio įnulinimu; 4) atliktas optinių stalų su pneumatiniais izoliatoriais ir kvazinulinio standžio virpesiu izoliavimo sistemos eksperimentinis dinaminių charakteristikų įvertinimas; 5) atliktas virpesių matavimo neapibrèžties ir gautų rezultatų patikimumo ịvertinimas.

Disertaciją sudaro įvadas, keturi skyriai, rezultatų apibendrinimas, naudotos literatūros ir autoriaus publikacijų disertacijos tema sąrašai, trys priedai.

Ivadiniame skyriuje aptariama tiriamoji problema, darbo aktualumas, aprašomas tyrimų objektas, formuluojamas darbo tikslas ir uždaviniai, aprašoma tyrimų metodika, darbo mokslinis naujumas, darbo rezultatų praktinè reikšmé, ginamieji teiginiai. Ivado pabaigoje pristatomos autoriaus paskelbtos publikacijos ir pranešimai konferencijose disertacijos tema ir disertacijos struktūra.

Pirmajame skyriuje analizuojami virpesių izoliavimo sistemų tipai, pasyviųjų, pusiau aktyviųų ir aktyviųų virpesių izoliavimo sistemų pranašumai ir trūkumai.

Antrajame skyriuje pateikta naujo tipo virpesių izoliavimo sistemų analizė ir dinaminiai tyrimai.

Trečiajame skyriuje pateikti optinių stalų ir platformos dinaminių charakteristikų eksperimentiniai tyrimai.

Ketvirtajame skyriuje pateikti kvazinulinio standžio ir sudètinių sistemų eksperimentiniai tyrimai bei virpesių matavimo rezultatų neapibrèžties tyrimai.

Disertacijos tema skaityti du pranešimai Lietuvos ir užsienio konferencijose, du moksliniai straipsniai įtraukti $\dot{i}$ ISI Web of Science sąrašą, du publikuoti respublikinių ir tarptautinių konferencijų straipsnių rinkiniuose. Užpatentuotas vienas išradimas. 


\section{Abstract}

In dissertation discuss about new created dynamic characteristics establishment of low-frequency $(0,7-50 \mathrm{~Hz})$ vibrations isolation system. Presented theoretical and experimental investigations.

Main goal of dissertation - is creation of dynamic parameters establishment methods for low-frequency vibration isolation systems and stiff quasi-zero vibrations isolation system, also investigate their dynamical characteristics and usage possibilities. Investigation object - low-frequency vibrations isolation mechanical systems and their dynamic characteristics establishment.

Wish to realize investigation goal, were solved those tasks: 1) In scientifically literature investigates types of passive and active vibration isolation systems, constructions, work principals and analyze; 2) Analyzed and theoretically introduced mechanical conceptions of dynamic characteristics establishment methods of the vibration isolation systems; 3) Created stiff quasi-zero vibration isolation method and system based on zeroing of spring stiffness; 4) Done experimental dynamic characteristics evaluations of optics tables with pneumatic isolation and stiff quasi-zero vibration isolation systems; 5) Done vibration measurement unscertainty and given results reliability evaluation.

Dissertation contents introduction, three parts, general conclusion of the results, used literature and list of author's themes published dissertations, three attachments.

In introduction part discuss about investigation problems, work actuality, described investigation object, formulated work goal and tasks, described investigation methods, work study novelties, practical meaning of the work results, defended reports. At the end of the introduction introduced author's placed publications and reports of the dissertation themes during conferences, also structure of the dissertation.

In the first part analyzed types of vibration isolation systems, advantages and disadvantages of passive, half active and active vibration isolation systems.

In the second part introduced new type of the vibration isolation system analyze and dynamic investigations.

In the third part introduced dynamic experimental characteristic investigation of the vibration isolation systems.

In the four part introduced dynamic characteristic kvasizero stiffnes of a complex vibration isolation system and research of an uncertainty of vibration measurements.

Dissertation theme be read 2 times in Lithuanian and also in foreign conferences, printed 2 times and placed into list of ISI Web of Science; two - in information of republic and international conferences. Patented 1 invention. 


\section{Turinys}

IVADAS

Problemos formulavimas......................................................................... 1

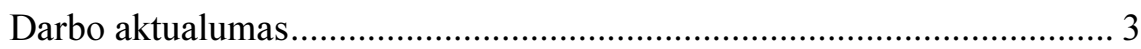

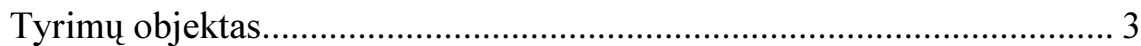

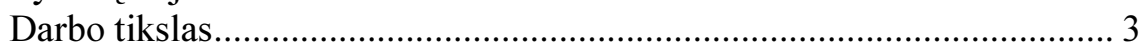

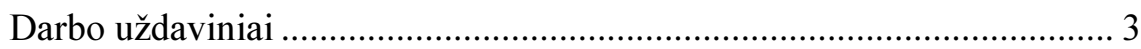

Tyrimų metodika ................................................................................... 4

Darbo mokslinis naujumas ....................................................................... 4

Darbo rezultatų praktinè reikšmè .......................................................... 5

Ginamieji teiginiai............................................................................ 5

Darbo rezultatu aprobavimas............................................................. 5

Disertacijos struktūra.............................................................................. 6

1. VIRPESIUU IZOLIAVIMO SISTEMU TOBULINIMO RAIDOS

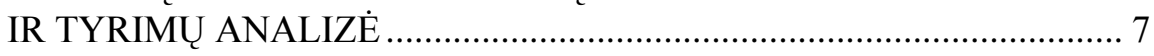

1.1. Virpesių izoliavimo sistemų tipai...................................................... 7

1.2. Pasyviosios virpesių izoliavimo sistemos ........................................ 12

1.3. Pusiau aktyvios virpesiu izoliavimo sistemos .................................... 19

1.4. Aktyviosios virpesių izoliavimo sistemos ......................................... 23

1.5. Neigiamo standžio pasyviosios virpesiu izoliavimo sistemos........... 27

1.6. Kvazinulinio standžio pasyvioji virpesių izoliavimo sistema ............ 32

1.7. Pirmojo skyriaus išvados ir disertacijos uždavinių formulavimas ... 39 


\section{2. ŽEMOJO DAŽNIO VIRPESIŲ IZOLIAVIMO SISTEMU}

DINAMINIAI TYRIMAI

2.1. Virpančios platformos (pagrindo) dinaminis pagrindimas............... 41

2.2. Optinio stalo ant virpančios platformos dinaminiai tyrimai............. 51

2.3. Kvazinulinio standžio virpesių izoliavimo sistemos naujumas

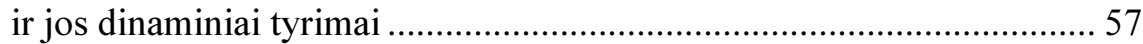

2.4. Sudètinès virpesių izoliavimo sistemos dinaminiai tyrimai ............. 65

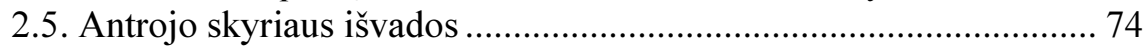

3. OPTINIŲ STALŲ IR PLATFORMOS DINAMINIŲ CHARAKTERISTIKU EKSPERIMENTINIAI TYRIMAI

3.1. Optinių stalų su pneumatiniais virpesių izoliatoriais eksperimentiniai tyrimai. .75

3.2. Stalo optinès plokštès ir platformos dinaminių charakteristiku eksperimentinio tyrimo ir skaičiavimo pavyzdžiai. 83

3.3. Optinių stalų izoliacinių atramų dinaminių charakteristikų tyrimai ir rezultatai..... 88

3.4. Trečiojo skyriaus išvados .......................................................... 96

4. MECHANINIŲ VIRPESIŲ IZOLIAVIMO SISTEMŲ EKSPERIMENTINIAI TYRIMAI.

4.1. Kvazinulinio (neigiamo) standžio virpesių izoliavimo sistemos tyrimas

4.2. Sudètinès virpesių izoliavimo sistemos dinaminių charakteristikų eksperimentiniai tyrimai 102

4.3. Virpesių matavimo rezultatų neapibrezžties tyrimai. 106

4.4. Ketvirtojo skyriaus išvados 113

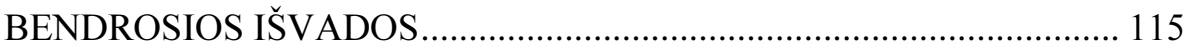

LITERATŪRA IR ŠALTINIAI ......................................................... 117

AUTORIAUS MOKSLINIŲ PUBLIKACIJŲ DISERTACIJOS TEMA SĄRAŠAS.

PRIEDAI

A priedas. Kvazinulinio standžio virpesių izoliavimo sistemos virpesių matavimų rezultatai

B priedas. Patentas LT 5883 „Mechaninè kvazinulinio standžio vibroizoliacinè sistema“" 125

C priedas. Sudètinès sistemos virpesių matavimų rezultatai. 


\section{Contents}

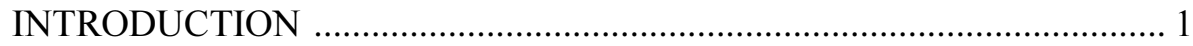

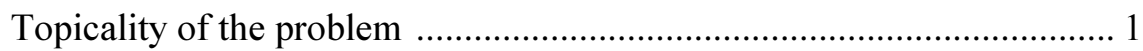

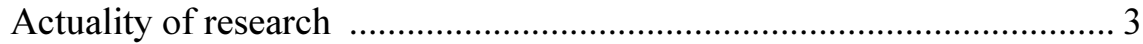

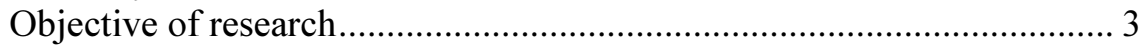

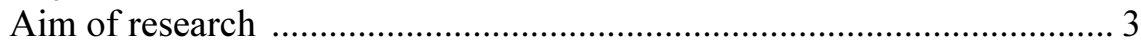

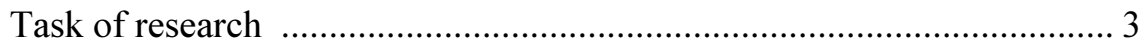

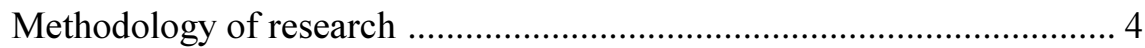

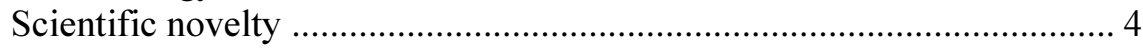

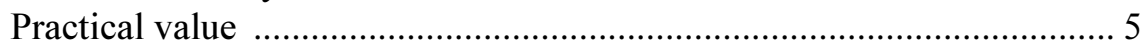

Defended propositions .................................................................... 5

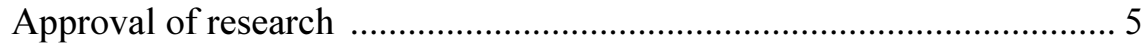

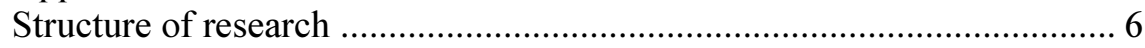

1. DEVELOPMENT EVOLUTION AND RESEARCH ANALYSIS OF VIBRATION ISOLIATION SYSTEMS ......................... 7

1.1. Types of vibration isolation systems .............................................. 7

1.2. Passive systems of vibration isolation.......................................... 12

1.3. Semi active vibration isolation systems ........................................ 19

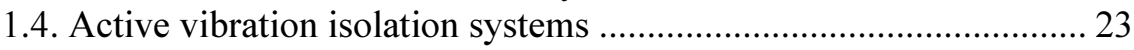

1.5. Vibration isolation systems of negative stiffness ............................ 27

1.6. Vibration isolation systems of kvasizero stiffness ........................... 32

1.7. Conclusions of the first chapter and formulation of dissertation tasks 
2.1. Dynamical background of vibrating platform (basis)

2.2. Dynamical research of optical table on vibrating platform .............. 51

2.3. Novelty and research of dynamics of a vibration isolation system of kvasizero stiffness.

2.4. Dynamical research of a complex vibration isolation system .......... 65

2.5. Conclusions of the second chapter ................................................ 74

3. EXPERIMENTAL RESEARCH OF DYNAMIC

CHARACTERISTICS OF OPTICAL TABLE AND PLATFORM ........ 75

3.1. Experimental research of optical tables with pneumatic isolators of vibration.

3.2. Examples of experimental research and calculation of dynamical characteristics of optical table isolation supports

3.3. Research and results of vibration transferability of

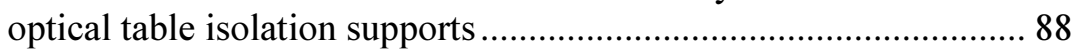

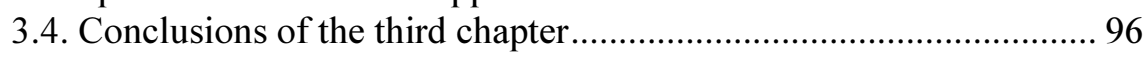

4. EXPERIMENTAL RESEARCH OF MECHANICAL VIBRATION ISOLATION SYSTEM

4.1. Research of kvasizero stiffnes vibration izolation systems

4.2. Experimental research of dynamic characteristics of a complex vibration isolation system 102

4.3. Research of an uncertainty of vibration measurements. 106

4.4. Conclusions of the four chapter. 113

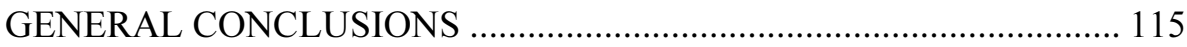

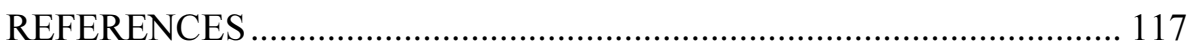

AUTHOR'S PUBLICATIONS ON A DISSERTATION SUBJECT ........ 123

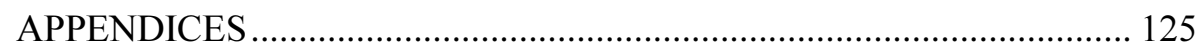

Appendix A. Measurement results of vibration izoliation

system of kvasizero stiffness

Appendix B. Patent LT 5883 "Mechanical system of vibration isolation of kvasizero stiffness". 144

Appendix C. Measurement results of complex vibration isolation system 157 


\section{lvadas}

\section{Problemos formulavimas}

Daugelis metrologinių priemonių yra jautrios mechaniniams žemojo dažnio virpesiams ir akustiniam triukšmui. Šie virpesiai gali kilti tiek iš pastato išorès, tiek iš vidaus, t. y. nuo pravažiuojančių mašinu̧, vejjo, šildymo, vẻdinimo ir oro kondicionavimo įrangos bei kitų laboratoriniu irenginių veikimo. Žinoma (Cessaro 1994; Hensley et al. 1999), kad pirminis mikroseisminis dažnis siekia $0,07 \mathrm{~Hz}$, o antrinio mikroseisminio svyravimo dažnis sudaro $0,14 \mathrm{~Hz}$ ir gali turèti didesnę amplitudę. Pastatai paprastai virpa esant dažniams nuo $0,1 \mathrm{iki} 1 \mathrm{~Hz}$, o tipiniai grindų dažniai yra nuo 10 iki $50 \mathrm{~Hz}$ vertikaliai ir nuo 1 iki $20 \mathrm{~Hz}$ horizontaliai, todèl jautrios matavimo įrangos darbo kokybei užtikrinti žemujų dažnių virpesių izoliavimas reikalingas ir aktualus. Yra daugybė žinomų techninių sprendimų, padedančių sumažinti ir redukuoti virpesių perduodamumą iš vienų mašinos dalių kitoms. Bendrai jie i̇vardijami kaip virpesių izoliatoriai (dempferiai) arba pakabų mechanizmai, pavyzdžiui, i̇vairūs amortizatoriai, tampriosios pagalvès, ivairiausios mechaninès spyruokless, pneumatiniai ir hidrauliniai įtaisai, ịvairiausios jų kombinacijos. Virpesių izoliavimo poreikis dideja, nes precizinès svarstyklès, optiniai mikroskopai ir kita jautri įranga, esanti palydovuose, orbitinėse stotyse, orbitiniuose teleskopuose (Eric 1996; Richman 1998), turi būti izoliuota nuo virpesių, kad galètų tinkamai veikti. Virpančios nanoskalès sukelia daug 
problemų, kai dirbama didesniais greičiais. Šiuo metu yra keli žemojo dažnio virpesių izoliavimo metodai - aktyvieji ir pasyvieji, kiekvienas iš jų turi savo pranašumų ir trūkumų. Pasyviosios virpesių izoliavimo sistemos sukuria mažiau šilumos nei aktyviosios, o tai svarbu, kai dirbama su priemonèmis, jautriomis šilumai. Be to, pasyviosios sistemos yra kur kas pigesnès ir patikimesnès nei aktyviosios, jas naudojant nereikia specialių priemonių slopinimui arba standžiui reguliuoti. Šiuo metu pasyviosios virpesių izoliavimo sistemos, tokios kaip optiniai stalai su pneumatiniais virpesių izoliatoriais lazerių centruose, plačiai naudojamos žemojo dažnio (4-5 Hz) virpesiams izoliuoti. Optinio stalo tipiniai virpesių intervalas $-2-7 \mathrm{~Hz}$, nes tai savasis dažnis, kuriame oro stalas rezonuoja (Hensly et al. 1999). Tačiau ypač žemiems (nuo 0,7 Hz) dažniams reikia geresnių izoliatoriu, siekiant geresnio rezultato dirbant su zondiniais mikroskopais ir interferometrais. Sukurti kvazinulinio (neigiamo) standžio izoliatoriai rezonuoja nuo $0,5 \mathrm{~Hz}$. Šis dažnis beveik neturi energijos, nes dideli virpesiai būtų labai neiprasti esant $0,5 \mathrm{~Hz}$ dažniui (McMahon 2009). Optiniai stalai ir aktyviosios sistemos ne itin gerai veikia, kai patenka i vakuuma, ypač aukštoje arba žemoje temperatūroje ir radiacineje aplinkoje. Tokia aplinka pasitaiko atliekant specifinius tyrimus su puslaidininkiais. Kvazinulinio (neigiamo) standžio sistemos gali dirbti vakuume, aukštose ir žemose temperatūrose bei veikiant radiacijai. Kvazinulinio (neigiamo) standžio sistemos yra kompaktiškos ir lengvai perkeliamos iš vietos i vieta. Kartais tenka naudoti optinius stalus su kvazinulinio (neigiamo) standžio sistemomis, nes tai leidžia sušvelninti nedidelius svorio pokyčius ir didelius poslinkius. Be to, kvazinulinio (neigiamo) standžio sistemos tinka lazerių virpesiams izoliuoti, nes lazerio pagrindas - interferometras, kuris yra itin jautrus prietaisas ir gali išskirti nanometrų skalès judesius. Jie paprastai turi labai ilgus mechaninius kreipiklius, kurie daro juos dar jautresnius virpesiams. Kad sudètinga moderni elipsometrinè technika pasiektų aukštą kokybę, turi būti mažas triukšmas, tada galima aptikti kraštinius judesius. Tinkamai izoliuotas interferometras leis pasiekti didžiausią galimą gebą. Taigi kvazinulinio (neigiamo) standžio $0,5 \mathrm{~Hz}$ virpesių izoliavimo sistemos suteikia tinkamą izoliacija, kitos sistemos tiesiog to negali, o aktyviosios virpesių izoliavimo sistemos turi ribotą dinamini diapazoną ir negali tinkamai funkcionuoti, kai virpesių amplitudès yra didelès, be to, reikalauja papildomo maitinimo ir specialios priežiūros.

Virpesių izoliavimo problemos plačiai tyrinèjamos daugelio pasaulio šalių mokslininkų: JAV (M. E. Ruzicka, T. Sashida, D. Karnop, S. Sommerfeldt, C. M. Harris), Europoje (H. Boudaoud, E. Luzzato), Rusijoje (K. V. Bolotin N. N. Frolov, I. I. Blechman, A. N. Zotov). Pastaruoju laiku pasirodè gana daug šiai tematikai skirtų Pietų Korejos, Japonijos, Kinijos mokslininkų darbų. Lietuvoje šioje srityje daug nuveike K. Ragulskis, R. Bansevičius, A. Jakštas.

Darbe pagrindinis dèmesys skirtas nustatyti mechaninès koncepcijos pasyvių virpesių izoliavimo sistemų gebejjimą izoliuoti žemujjų $(0,7-50 \mathrm{~Hz})$ dažnių 
virpesius. Nors atliekami tyrimai taikomi specifiniams virpesių izoliavimo sistemų dinaminių charakteristikų nustatymo uždaviniams spręsti, jų rezultatai gali būti naudojami naujos kartos, kokybiškai naujų savybių virpesių izoliavimo sistemoms kurti.

\section{Darbo aktualumas}

Optiniai stalai su pneumatiniais virpesių izoliatoriais tinka lazerių centrams, tačiau, siekiant geresnio rezultato dirbant su zondiniais mikroskopais ir interferometrais, reikia naujos kartos virpesių izoliavimo sistemų, kurios leistų virpesiams jautriai irangai, tokiai kaip zondinis mikroskopas, mikroskverbiklio testeris, profilio matuoklis ir skenuojantis elektroninis mikroskopas, veikti šiurkščiomis sąlygomis ir smarkių virpesių aplinkoje, ko negalima būtų pasiekti naudojantis geriausių charakteristikų optiniais stalais ar kitomis aktyviosiomis virpesių izoliavimo sistemomis. Todèl reikalingi nauji izoliavimo būdai ir sistemos, pagristos mechanikos principais, aukšto ergonomiškumo lygio, gerokai kompaktiškesnès nei optiniai stalai ir paprastesnès negu aktyviosios virpesių izoliavimo sistemos, kurias būtu galima daug lengviau perkelti iš vietos i vietą. Tai užtikrintų laiku atliekamo virpesių izoliavimo kokybę, leistų naudotis ten, kur to reikia darbo vietose, ant stalų arba grindų, vakuuminèse kamerose, aukštose arba žemose temperatūrose, radiacinejje aplinkoje.

\section{Tyrimų objektas}

Tyrimų objektas - mechaninès pasyviosios žemojo dažnio virpesių izoliavimo sistemos.

\section{Darbo tikslas}

Ištirti mechanines pasyviąsias žemojo dažnio virpesių izoliavimo sistemas ir suformuluoti tokių sistemų tyrimo metodiką.

\section{Darbo uždaviniai}

Darbo tikslui pasiekti reikia spręsti šiuos uždavinius: 
1. Atlikti mokslinès literatūros apžvalgą apie virpesių izoliavimo tipus, sistemas, jų tyrimus ir analizę.

2. Išanalizuoti ir pagristi mechaninių žemojo dažnio virpesių izoliavimo sistemų dinamini efektyvumą.

3. Pasiūlyti optinių stalų ir pneumatinių virpesių izoliatorių eksperimentinių tyrimų metodiką.

4. Atlikti kvazinulinio (neigiamo) standžio virpesių izoliavimo sistemų dinaminių charakteristikų eksperimentinius tyrimus.

5. Atlikti sudètinių virpesių izoliavimo sistemų dinamikos eksperimentinius tyrimus ir įvertinti gautų rezultatų neapibrèžti.

\section{Tyrimų metodika}

Rengiant darbą atlikti teoriniai ir eksperimentiniai tyrimai taikant skaitmeninès analizès principus, atliekant lyginamuosius virpesių izoliavimo sistemų matavimus ir taikant matematinę statistinę analizę gautų rezultatų patikimumui įvertinti.

\section{Darbo mokslinis naujumas}

Rengiant disertaciją buvo gauti šie mechanikos inžinerijos mokslui nauji rezultatai:

1. Atlikta žemojo dažnio virpesių izoliavimo sistemų analizė taikant lyginamuosius jų efektyvumo vertinimo metodus. Gautos mechaninių pasyviujuc žemo dažnio virpesių izoliavimo sistemų dinaminès charakteristikos (perduodamumas) leidžia ịvertinti virpesių izoliavimo efektyvumą. Nustatyta, kad tokios sistemos gali izoliuoti virpesius $0,7-50 \mathrm{~Hz}$ dažnių ruože.

2. Pasiūlyti optinių stalų ir pneumatinių virpesių izoliatorių eksperimentiniai tyrimo metodai, leidžiantys projektuoti ir tobulinti tokias sistemas tais atvejais, kai jų dinaminès charakteristikos yra nežinomos, o kitus metodus taikyti sunku. Pateikti eksperimentinio tyrimo rezultatai rodo, kad optinès plokštès ir platforma iki $80 \mathrm{~Hz}$ yra absoliučiai standūs kūnai.

3. Pasiūlyti kvazinulinio standžio virpesių izoliavimo metodai leidžia spręsti žemojo $(0,7-50 \mathrm{~Hz})$ dažnio virpesių izoliavimą veikiant harmoniniam, impulsiniam ir baltajam triukšmui. 


\section{Darbo rezultatų praktinè reikšmè}

Taikant parengtą mechaninę pasyviają žemojo dažnio virpesių izoliavimo sistemą yra gerokai supaprastinamas virpesių izoliavimo procesas, jis tampa pigesnis, užima mažiau laiko ir darbo sąnaudų, palyginti su kitais šiuo metu taikomais virpesių izoliavimo būdais.

\section{Ginamieji teiginiai}

1. Naujas kvazinulinio standžio virpesių izoliavimo metodas, pagrịstas mechanikos principais ir masès išlyginimu.

2. Sukurta eksperimentinio tyrimo metodika leidžia įvertinti virpesių izoliavimo sistemų dinamines charakteristikas ir jų skaitines vertes.

3. Sukurto naujo kvazinulinio standžio virpesių izoliavimo metodo praktinio taikymo galimybių pagrindimas, remiantis atliktų eksperimentų virpesių matavimų rezultatų analize.

\section{Darbo rezultatu aprobavimas}

Disertacijos tema išspausdinti du moksliniai straipsniai žurnaluose, itrauktuose i ISI Web of Science duomenų bazę (Kilikevičius, Jurevičius, Berba 2010; Jurevičius, Kilikevičius, Berba 2011); vienas - respublikinès konferencijos straipsniu rinkinyje (Berba 2011); vienas - tarptautinio simpoziumo straipsniu rinkinyje (Berba, Jurevičius 2012). Užpatentuotas vienas išradimas (Berba et al. 2012).

Disertacijoje atliktų tyrimų rezultatai buvo paskelbti dviejose mokslinèse konferencijose Lietuvoje ir užsienyje:

- Tarptautineje mokslineje konferencijoje: The $7^{\text {th }}$ international Symposium KOD 2012 „Machine and industrial design in mechanical engineering“ 2012 m., Vengrija.

- Respublikinèje mokslinèje studentų, magistrantų, doktorantu, jaunujų mokslininkų konferencijoje „Mechanika, medžiagų inžinerija, pramonės inžinerija ir vadyba. Fizika ir fizine kompiuterija“ 2010 m., Vilnius. 


\section{Disertacijos struktūra}

Disertaciją sudaro ivvadas, keturi skyriai ir bendrosios išvados, trys priedai.

Darbo apimtis - 126 puslapiai be priedų, tekste panaudota 113 formulių, 67 paveikslai ir 9 lentelès. Rašant disertaciją naudotasi 141 literatūros šaltiniu. 


\section{1}

\section{Virpesiu izoliavimo sistemu tobulinimo raidos ir tyrimu analizé}

Skyriuje nagrinejami virpesių izoliavimo sistemų tipai, virpesių izoliavimo metodai ir sistemos, jų tobulinimo būdai, neigimo ir kvazinulinio standžio virpesių izoliavimo sistemų specifika, teigiami ir neigiami aspektai. Remiantis literatūros šaltiniais pateikta virpesių izoliavimo sistemų analizè ir tyrimai. Šio skyriaus medžiaga paskelbta autoriaus publikacijoje (Berba 2012).

\subsection{Virpesių izoliavimo sistemų tipai}

Kuriant žemojo dažnio virpesių izoliavimo sistemas, šiuo metu daug dèmesio skiriama aktyviosioms ir pasyviosioms virpesių izoliavimo sistemoms (Snyder 1997). Triukšmo ir virpesių kontrolę gerai aprašè Bies, Hansen (1996) ir Haris (1987). Virpesių izoliavimo sistemos gali būti pasyviosios, pusiau aktyvios ir aktyviosios (1.1 pav.). Iki $1990 \mathrm{~m}$. daugiausia buvo naudojamos tik pasyviosios sistemos (Mead 1999). 


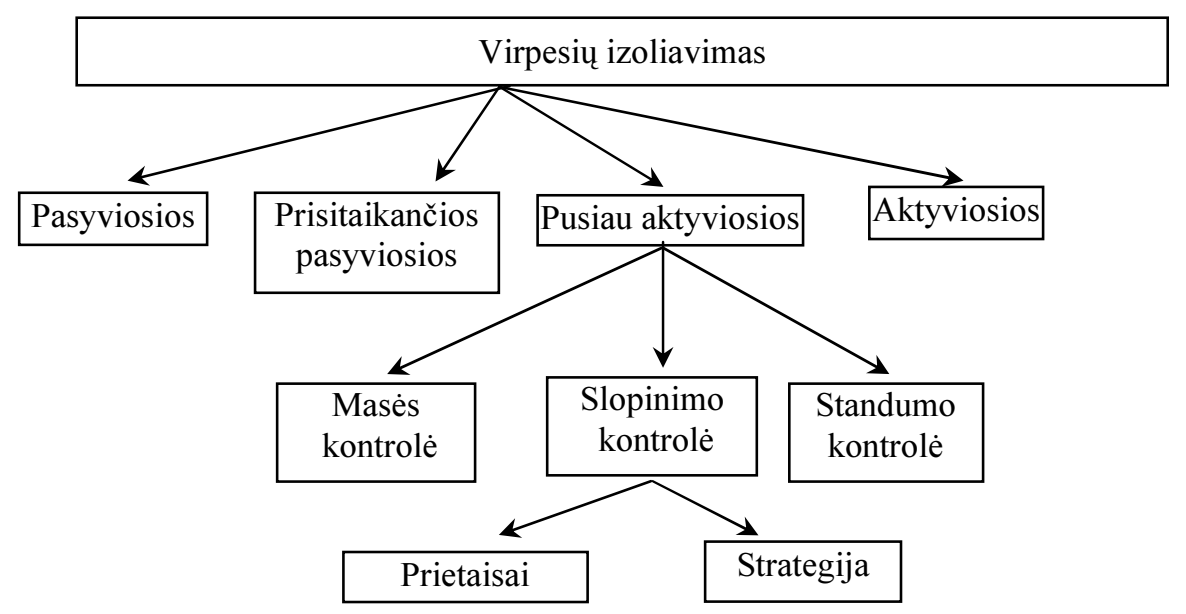

1.1 pav. Virpesių izoliavimo sistemų tipai (Bernhard 1992; Vijayan 2009)

Fig. 1.1. Overview of vibration isoliation methods in the literature (Bernhard 1992; Vijayan 2009)

Iprastinès pasyviosios (optiniai stalai) virpesių izoliavimo sistemos dažnai naudojamos aukštiesiems ir žemiesiems (4-5 Hz) dažniams izoliuoti ir virpesių rezonanso kontrolei, kai reikalingas aukšto lygio virpesių izoliavimas (Kornopp 1973; Snyder 1997; Bies 1996; Fuller 1996; Soong 1990; Rao 1995; White 1982). Šis kompromisas būdingas pasyviosioms virpesių izoliavimo sistemoms, tačiau pasyviosios sistemos turi eksploatacinių apribojimų (Snyder 1997; Fuller 1996). Kai kurie autoriai (Franchek 1995; Bernhard 1992) teigia, kad aktyviosios sistemos kai kuriais atvejais gali suteikti geresnę virpesių izoliaciją. Tais atvejais, kai reikalaujama geresnių izoliavimo rezultatų, kurių negali suteikti pasyviosios sistemos, kuriamos aktyviosios virpesių izoliavimo sistemos. Kai kuriais atvejais aktyviosios virpesių izoliavimo sistemos parode geresnes izoliavimo charakteristikas nei pasyviosios (Vijayan 2009). Tačiau taip pat žinoma, kad aktyviosios sistemos yra brangesnès, sudètingesnès ir mažiau patikimos nei pasyviosios. Pagrindinis aktyviujų sistemų naudojimo apribojimas tas, kad virpesiams izoliuoti reikalingas išorinis maitinimas. Todel aktyviosios sistemos naudojimas gali būti apribotas tik tais atvejais, kai labai padidèja išlaidos, sudètingumas ir mase. Todèl, siekiant sumažinti išlaidas ir pagerinti izoliavimo charakteristikas, buvo sukurta naujo tipo neigiamo ir kvazinulinio standžio pasyviosios sistemos (McMahon 2009; Zotov 2005; Berba, 2012). Vieno laisvės laipsnio tipinių virpesių izoliavimo sistemų schemos parodytos 1.2 pav. Tokios sistemos turi izoliuoti pagrindu perduodamus įvairaus pobūdžio virpesius. 


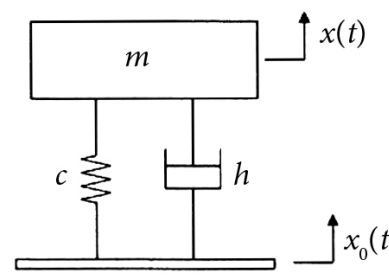

a

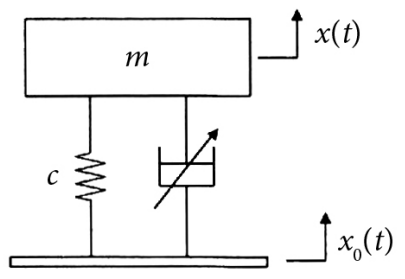

$\mathrm{b}$

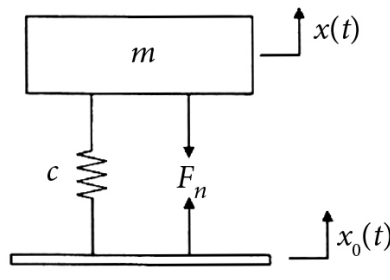

$\mathrm{c}$

1.2 pav. Tipinès virpesių izoliavimo schemos: a - pasyvioji sistema; b - pusiau aktyvi; c - aktyvioji sistema (Harris 1987; Liu 2005)

Fig. 1.2 Schematic of vibration isoliation system with different type of dampers: $\mathrm{a}$ - conventional passive damper; $\mathrm{b}$ - semi-active damper; $\mathrm{c}$ - active device (Harris 1987; Liu 2005)

Pasyvioji sistema turi iš anksto nustatytas savybes, kurios negali būti koreguojamos, kol sistema veikia. Virpesių perduodamumas priklauso nuo žadinimo dažnio. 1.3 pav. pavaizduotas pasyviajai sistemai būdinga paredava $T$ esant skirtingoms slopinimo $\xi$ eikšmėms (Vijayan 2009). Kai $T \leq 1$, virpesių izoliavimas užtikrinamas.

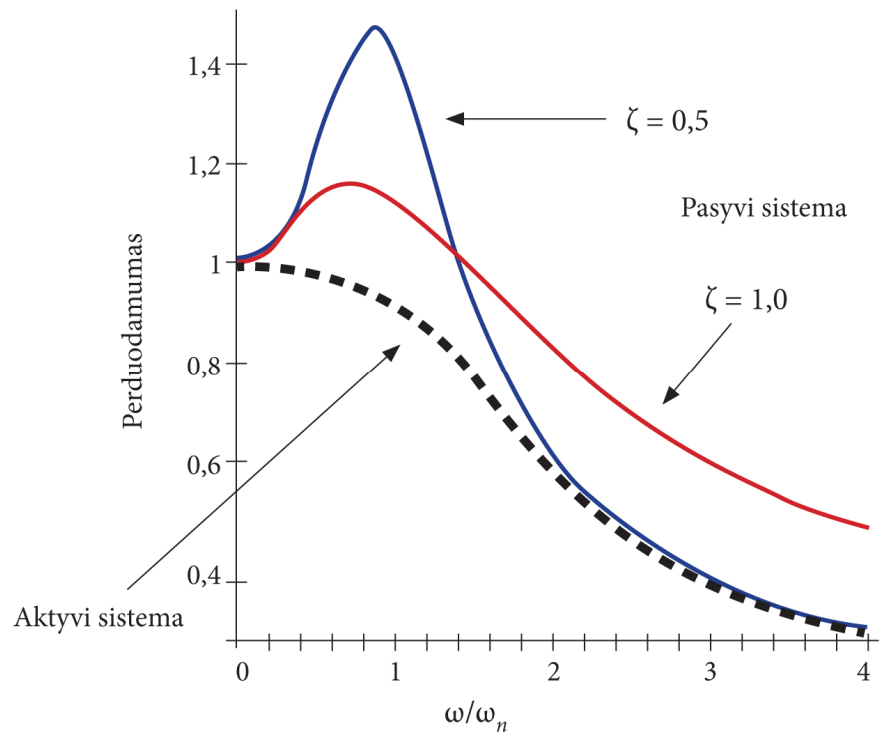

1.3 pav. Virpesių perduodamumas pasyviosiose (ištisinè linija) ir aktyviosiose sistemose (punktyrinè linija) (Vijayan 2009)

Fig. 1.3 A vibration transmissibility of passive system (solid lines) and an active system (dashed line) (Vijayan 2009) 
Pasyvi sistema yra veiksminga tik esant žadinimams, kurių dažnis daug didesnis nei jos nuosavas dažnis. Vis dèlto praktikoje išorinis žadinimas gali turèti dažni, kintamą laike, ar gali sudaryti dažnių spektrą. Tokiu atveju virpesių izoliavimo sistemos veiksmingumas sumažèja, kai žadinimo dažnis artimas savajam sistemos dažniui. Nustatant sistemos slopinimo parametrus, kai reikia suderinti skirtingų dažnių izoliaciją ir apibendrinti sistemos efektyvumą, galutinis rezultatas gali būti nepatenkinamas.

Kitą vertus, aktyvi virpesių izoliavimo sistema išorinę energiją tiesiogiai išsklaido sistemoje naudojant vykdiklius, jutiklius ir valdiklius. Vykdikliai turi pajègti suteikti norimas jègas ar poslinkius sistemoje, jutikliai naudojami judesiui aptikti sistemoje (pagreičio, greičio ar santykinio poslinkio), valdikliai norint apskaičiuoti reikalingas išorines jègas ar poslinkius ir nusiųsti reikiamus signalus vykdikliams.

Iš įvairių konfigūracijų aktyviụjų virpesių izoliavimo sistemų pats populiariausias tipas - inercinio grižtamojo ryšio sistemos, kuriose perduodamumas, artimas savajam dažniui, yra sumažintas, išlaikant aukštojo dažnio efektyvumą. Perduodamumas tipinėse aktyviosiose sistemose parodyta punktyrine linija 1.3 paveiksle (Vijayan 2009).

Pusiau aktyvi sistema sieja pasyviosios ir aktyviosios sistemų savybes. Panašiai kaip ir aktyviosios sistemos, ji naudoja vykdiklius, pritaikytus jègoms ir poslinkiams. Vis dèlto jègos ir poslinkiai negali būti panaudoti pasirinktinai, bet jie yra sistemos judesio funkcijos. Kitaip tariant, vykdikliai pusiau aktyviose sistemose laikomi pasyviaisiais elementais, kurių savybès (slopinimo santykis ir standis) gali būti keičiamos taip, kad valdymas gali būti igyvendintas nenaudojant išorinès jègos sistemoje, išskyrus mažą jègos kiekį, reikalingą vykdiklio savybėms pakeisti. Jutikliai naudojami kaip ir aktyviosiose sistemose judesiams aptikti, valdikliai nulemia norimas vykdikliu savybes.

Pusiau aktyvios sistemos skirstomos $i$ tris grupes: kintamojo standumo, kintamojo slopinimo (1.4 pav.) ir kintamosios masès. Kadangi masė negali būti pakeista per trumpą laika, daugeliu atvejų taikomos tik dvi pirmosios grupès (Karnopp 1974).

Pirmos grupès sistemose standumas koreguojamas nustatant ne rezonansinę būklę (Liu 2005). Antros grupès pusiau aktyvios sistemos eksploatuojamos pagal pusiau aktyvią slopinimo kontrolès strategija, siekiant pasyviai sukurti slopinimo jègą (Choi 2001; Liu 2005).

Slopinimas, susijęs su masès inercija, buvo pavadintas skyhook (1.5 pav.) pusiau aktyvia sistema (Mead 1999; Ahmodin 2009). 


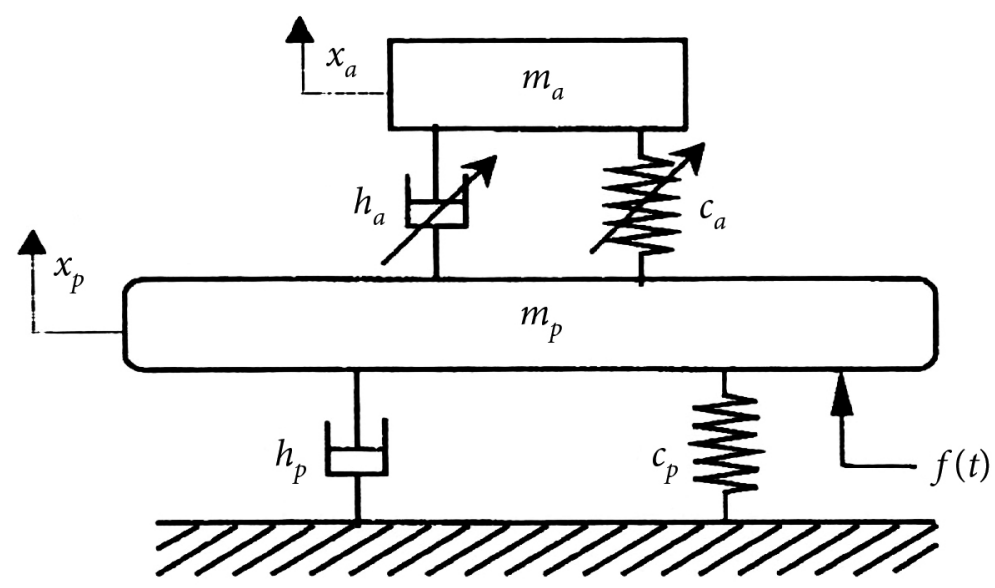

1.4 pav. Pusiau aktyvi sistema ant pasyviosios virpesių izoliavimo sistemos (Jalili 2002)

Fig 1.4. Semi-active absorber to passive system (Jalili 2002)
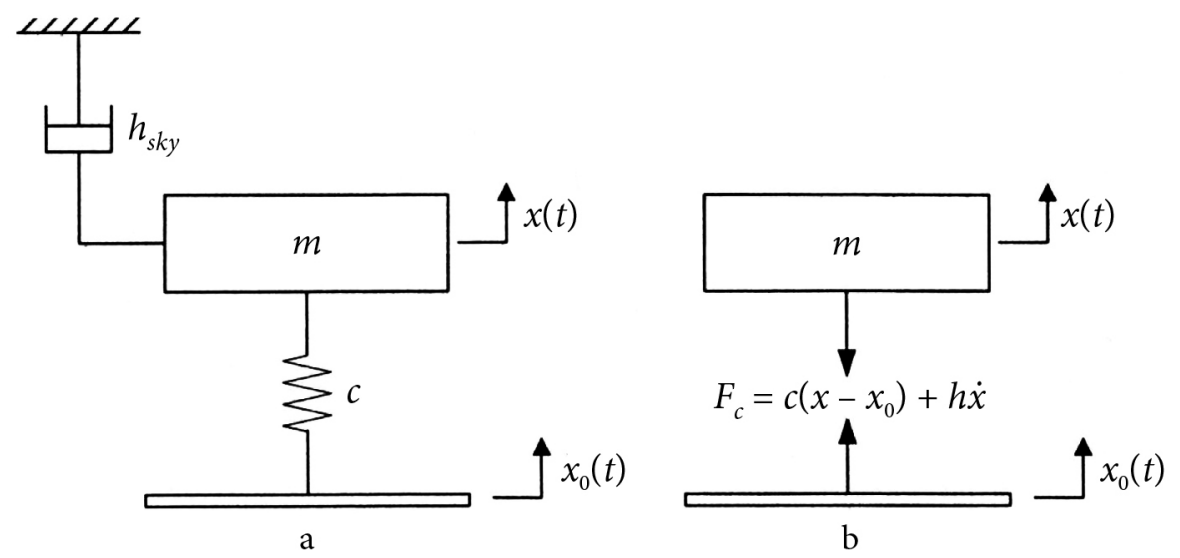

1.5 pav. Skyhook pusiau aktyvi sistema (a) ir aktyvi sistema (b) (Mead 1999)

Fig. 1.5. Skyhook system and its active equivalent (a) schematic with a skyhook damper; (b) active system (Mead 1999)

Lyginant aprašytas sistemas su skirtingais slopinimo koeficientais vieno laisvès laipsnio sistemai, kai pagrindas turi kinematini žadinima, judejjimo lygti su ịprastu klampiu slopinimu ir kintamuoju slopinimo koeficientu galima užrašyti taip:

$$
m \tilde{x}(t)+h(t)\left(\dot{x}(t)-\dot{x}_{0}(t)\right)+c\left(x(t)-x_{0}(t)\right)=0 .
$$


čia $h(t)$ sistemos slopinimo koeficientas, kuris gali kisti laike. Skirtingu tipu slopintuvų slopinimo koeficientas apibrèžiamas ivvairiai (Lui 2005).

Standartinems ir skyhook pasyviosioms sistemoms analitinis lygties sprendimas gaunamas iš judejjimo lygties (1.1). Tačiau pusiau aktyvių sistemų analitinis sprendimas neimanomas, kai sistemos slopinimo koeficientas kinta laike.

\subsection{Pasyviosios virpesių izoliavimo sistemos}

Klasikinès sistemos. Yra dviejų tipų pasyviosios virpesių izoliavimo sistemos: tai pamato izoliacija ir naudojamų priemonių izoliacija. Viena plačiausiai igyvendinamų ir pritaikytų seisminès apsaugos sistemų yra pamatų izoliacija. Seisminiu pamatu izoliacija (Skinner et al. 1993; Naeim, Kelly 1999) yra technologija, kuri sumažina žemès drebejjimo poveiki atskiriant pastatą ir jo turini nuo potencialiai pavojingo grunto, ypač kai dažnių intervalas turi didelị poveikị pastatui. Pamatų izoliacijos veiksmingumo, veikiant įvairių tipų seisminiam žadinimui, tyrimas paskatino teoriškai ir eksperimentiškai analizuoti bei tirti pamatų izoliaciją (Yang et al. 1996; Makris 1997; Johnson 1999; Spencer et al. 1999; Symans, Kelly 1999; Yoshida et al. 1999). Pamatų izoliacija, papildyta aktyviais ar išmaniais itaisais, duoda daug geresnių rezultatų (1.6 pav.).

Precizinėms matavimo ir tyrimo priemonėms naudoti pamatų izoliaciją yra brangu ir ne visuomet tai galima padaryti. Todèl dažniausiai naudojamos sistemos, susidorojančios su pagrindo virpesiais, pagrịstos pasyviaja virpesių triukšmo kontrole. Šios sistemos sumažina virpesius ir triukšmą tiesiog išsklaidydamos energiją kaip šilumą (Enrico 2003). Tokią sistemą sudaro spyruoklè (tamprusis elementas) ir energijos slopintuvas. Taip pat gali būti naudojami elastometrai, skysčiai arba neigiamo standumo elementai. Spyruoklès priešinasi virpesiu poslinkiui itempdamos priešingas jègas, proporcingas jų poslinkiui. Slopintuvas sudarytas iš stūmoklio, judančio per klampų skysti, arba laidininko, judančio magnetiniame lauke, kuris išskaido kinetinę energiją ir išskaido ją kaip šilumą. Vis dèlto spyruokle turi savajị rezonansini dažni, kuris priklauso nuo jos standžio, ir jeigu virpesių dažnis priarteja prie savojo sistemos dažnio, spyruoklè tampa stiprintuvu. Tokia nesudètinga sistema nelabai gerai veikia esant virpesiams, žemesniems nei $10 \mathrm{~Hz}$ (Conola 2009). Taigi ju slopinimo lygis yra gana prastas. Tačiau jos yra pigios ir paprastos, todèl plačiai naudojamos (Enrico 2003). Pasyvioji sistema turi iš anksto nustatytas savybes, kurios negali būti koreguojamos, kol sistema veikia (Vijayn 2009). 


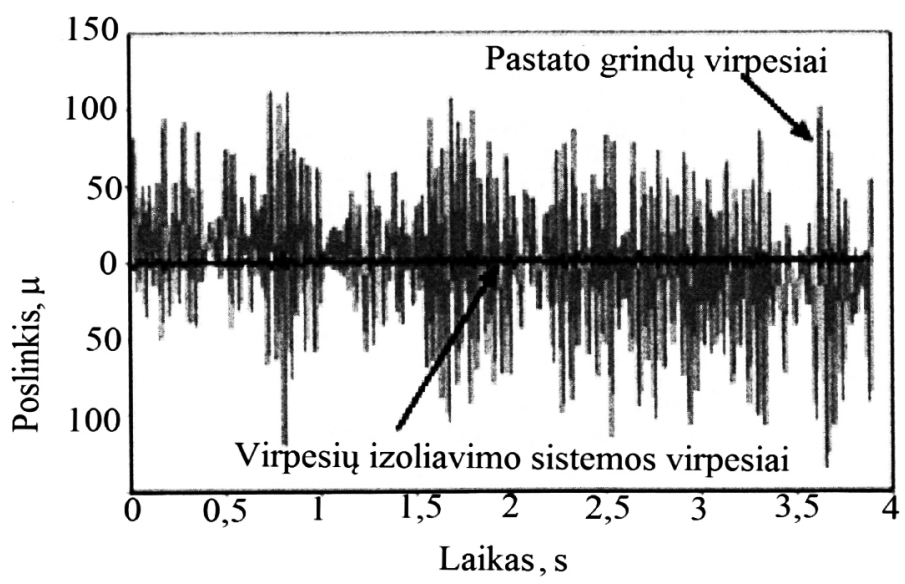

1.6 pav. Grindų virpesių izoliacija (Shaidani 2008)

Fig. 1.6. Typical Building Vibration (Shaidani 2008)

Paprasčiausios klasikinès pasyvios virpesių izoliavimo sistemos parodytos 1.7 paveiksle (Oueslati 1994). Tokios sistemos diferencialinè judejjimo lygtis:

$$
m \ddot{x}+h\left(\dot{x}-\dot{x}_{0}\right)+c\left(x-x_{0}\right)=0,
$$

čia $m$ - masé; $h$-slopinimo koeficientas; $c$-spyruoklès standis; $x$ - masès judèjimo amplitude; $x_{0}$ - pagrindo judejjimo amplitudè.
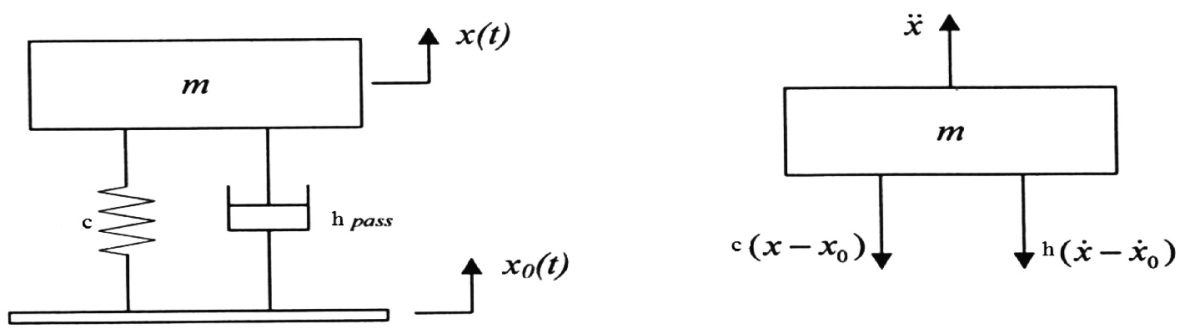

1.7 pav. Pasyviosios virpesių slopinimo sistemos schemos (Ouesalati 1994)

Fig. 1.7. Schematic of System with a conventional passive damper (Ouesalati 1994)

Ivertinant slopinimo koeficientą $\xi=h / 2 m \omega_{0} r$ savaji dažni $\omega_{0}=\sqrt{c / m}$ lygtis (1.2) igauna toki pavidalą:

$$
\ddot{x}+2 \xi \omega_{0} \dot{x} \omega_{0}^{2} x=2 \xi \omega_{0} \dot{x}_{0}+\omega_{0}^{2} x_{0} .
$$


Tokios sistemos absoliutusis perduodamumo koeficientas (Rao 1995):

$$
T_{\ddot{x}}=\frac{\ddot{x}}{\ddot{x}_{0}}=\frac{\sqrt{1+\left(2 \zeta \frac{\omega}{\omega_{0}}\right)^{2}}}{\sqrt{\left[1-\left(\frac{\omega}{\omega_{0}}\right)^{2}\right]^{2}+\left[2 \zeta \frac{\omega}{\omega_{0}}\right]^{2}}} .
$$

Santykinis perduodamumas yra:

$$
T_{x-x_{0}}=\left|\frac{X-X_{0}}{X_{0}}\right|=\frac{\left(\frac{\omega}{\omega_{0}}\right)^{2}}{\sqrt{\left[1-\left(\frac{\omega}{\omega_{0}}\right)^{2}\right]^{2}+\left[2 \zeta \frac{\omega}{\omega_{0}}\right]^{2}}} .
$$

Pagreičio ir santykinio poslinkio perduodamumas parodytas 1.7 paveiksle, a, b. 1.7 pav., a, matome, kad žadinimo dažnis $\omega>\sqrt{2} \omega_{0}$ ideja arti rezonanso ir beveik vienodas esant žemajam $\omega>0,3 \omega_{0}$ dažniui. Todèl reikia atsakingai parinkti spyruoklès standi.

Rezonansinès amplitudès kontrolè vykdoma slopinimu. Didinant slopinimą sumažeja rezonansinè reakcija, bet tai didina perduodamumą izoliacijos diapazone $\omega / \omega_{0} \geq \sqrt{2}$ Jei be slopinimo, tai perduodamumo rezonansas būtų begalinis. Aukštojo dažnio perduodamumas šiuo atveju asimptotinis krintamas $40 \mathrm{~dB} /$ dekadai, suteikiantis daugiau izoliacijos. Tai sudaro seniai žinomas kompromisas tarp geresnès rezonanso kontrolès ir prastos virpesių izoliacijos esant aukštajam dažniui dèl fiksuotų slopinimų. Iš tiriamų santykinių poslinkių perduodamumo kreiviu (1.7 pav., b) galima matyti, kad aukščiausia slopinimo verte gaunama visame santykinio poslinkio perduodamumo dažnyje esant žemiausiai vertei.

Skyhook pasyvusis slopinimas. Judejjimo lygti sistemai su skyhook slopinimu (1.9 pav.) galima užrašyti taip (Karnopp 1974; Liu 2005):

$$
m \ddot{x}+h_{s k y} \ddot{x}+c\left(x-x_{0}\right)=0,
$$

čia $h_{s k y}-s k y h o o k$ slopintuvo slopinimo koeficientas. 


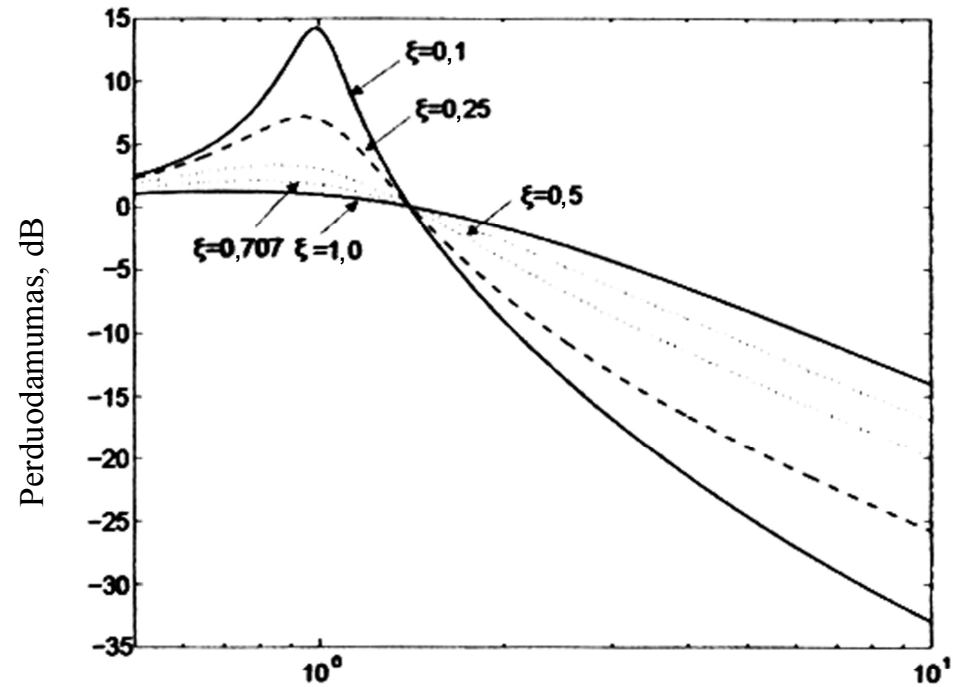

Dažnių santykis, $\omega / \omega_{0}$

a

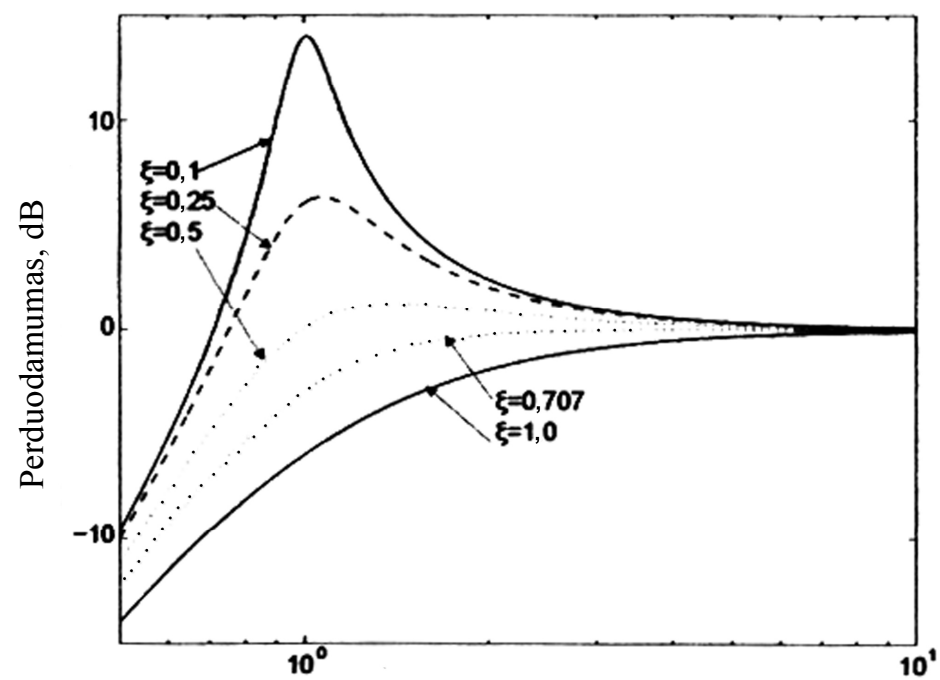

Dažnių santykis, $\omega / \omega_{0}$

b

1.8 pav. Iprastinès pasyvios sistemos perduodamumas: a - absoliutinè; b - santykinè (Liu 2005)

Fig. 1.8. Transmissibility of a conventional passive system: a - absoliute transmissibility; b - relative transmissibility (Liu 2005) 
Iš anksčiau pateiktos lygties išvedama masės judejjimo lygtis:

$$
\ddot{x}+2 \zeta \omega_{n}^{2}\left(x-x_{0}\right)=0
$$

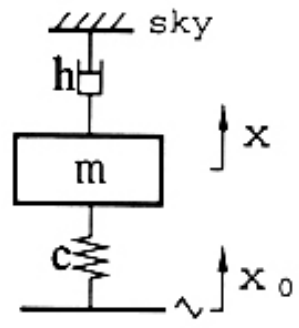

a

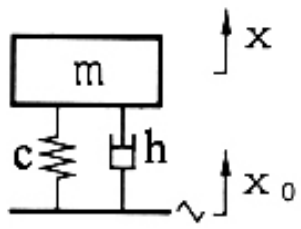

$\mathrm{b}$

1.9. pav. Skyhook konfigūracija: a - klasikinė; b - pasyvi (Karnopp 1974; Liu 2005)

Fig. 1.9. Skyhook system (a); passive sistem (b) (Karnopp 1974; Liu 2005)

Sistemos perduodamumas su skyhook slopintuvu gaunama taip:

$$
T_{\dot{x}}=\frac{1}{\sqrt{\left[1-\left(\frac{\omega}{\omega_{0}}\right)^{2}\right]^{2}+\left[2 \xi \frac{\omega}{\omega_{0}}\right]^{2}}}
$$

Santykinis perduodamumas:

$$
T_{x-x_{0}}=\frac{\sqrt{\left(\frac{\omega}{\omega_{0}}\right)^{4}+\left(2 \xi \frac{\omega}{\omega_{0}}\right)^{2}}}{\sqrt{\left[1-\left(\frac{\omega}{\omega_{0}}\right)^{2}\right]^{2}+\left(2 \xi \frac{\omega}{\omega_{0}}\right)^{2}}}
$$

Šie perduodamumo koeficientai parodyti 1.10 pav., a, b. Matome, kad yra kompromisinè rezonanso kontrolè ir izoliacija. 


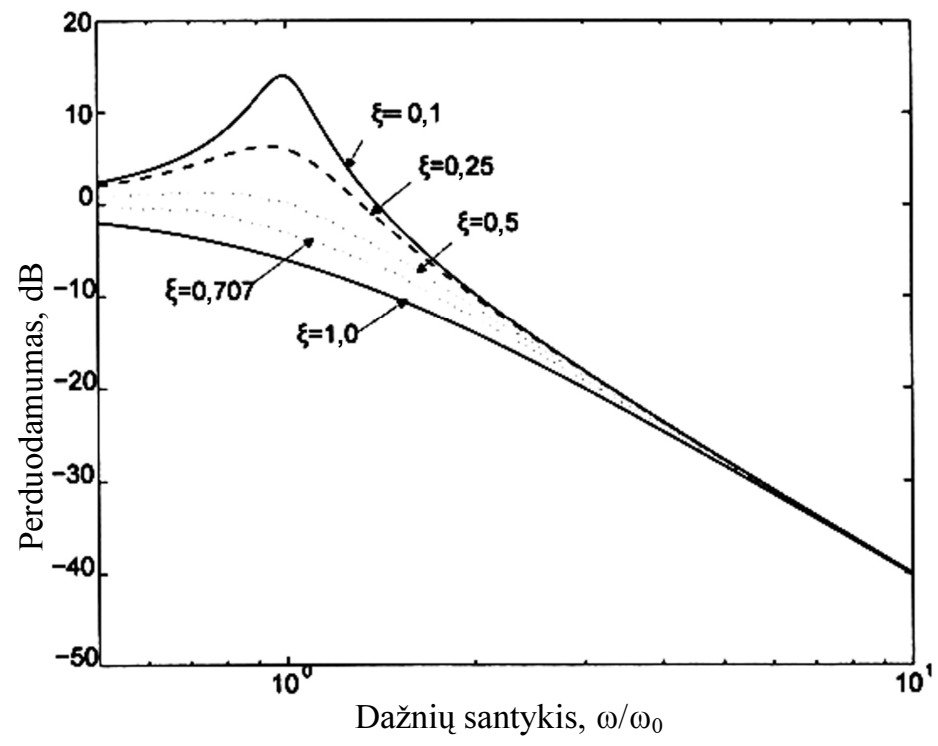

a

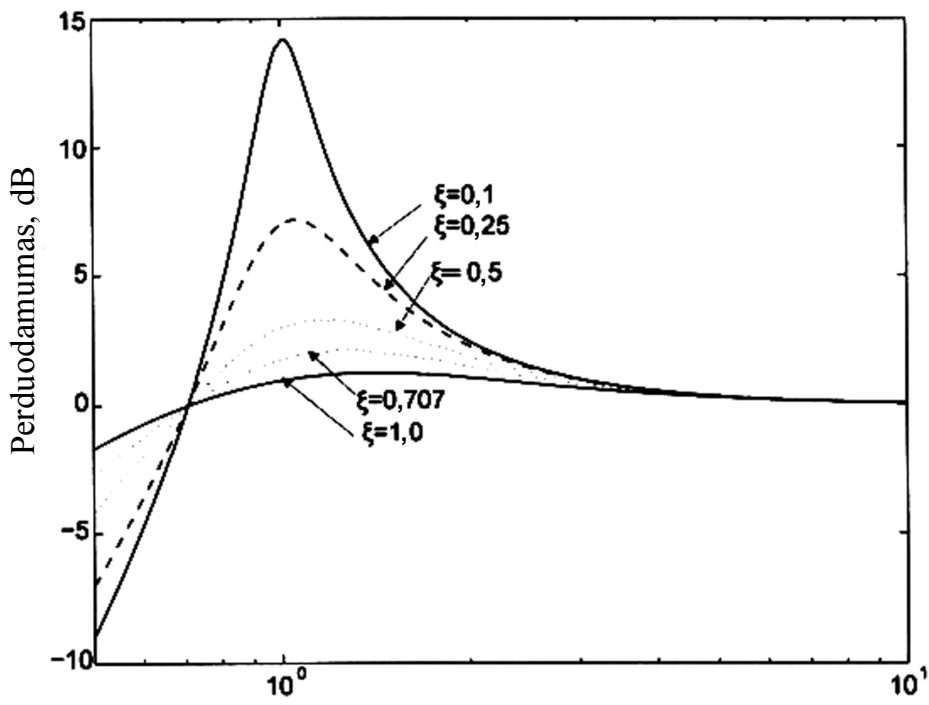

Dažnių santykis, $\omega / \omega_{0}$

b

1.10 pav. Skyhook sistemos perduodamumas: a - absoliuti; b - reliatyvi (Liu 2005)

Fig. 1.10. Transmissibility of a skyhook system: a - absoliute transmissibility; b - relative transmissibility (Liu 2005) 
Eksperimentiniai pasyviujų izoliavimo sistemų perduodamumo rezultatai rodo, kad esant žemiesiems dažniams $(2-4 \mathrm{~Hz})$ perduodamumas yra didelis. Tokios sistemos blogai slopina žemujų dažnių virpesius (Conolly 2009).

Optiniai stalai. Tai pasyviosios virpesių izoliavimo sistemos sudarytos iš korinès konstrukcijos optinès plokštès ir pneumatinių virpesių izoliatorių. Svarbiausios optinio stalo charakteristikos yra optinès plokštés slankis, pneumatinių virpesių izoliatorių perduodamumas ir stalo rezonansinis dažnis. Optinès plokštès korinès konstrukcijos fragmentas ir slankio kreivè parodyta 1.11 pav. a, b (Fundamentals of vibration... 2009).

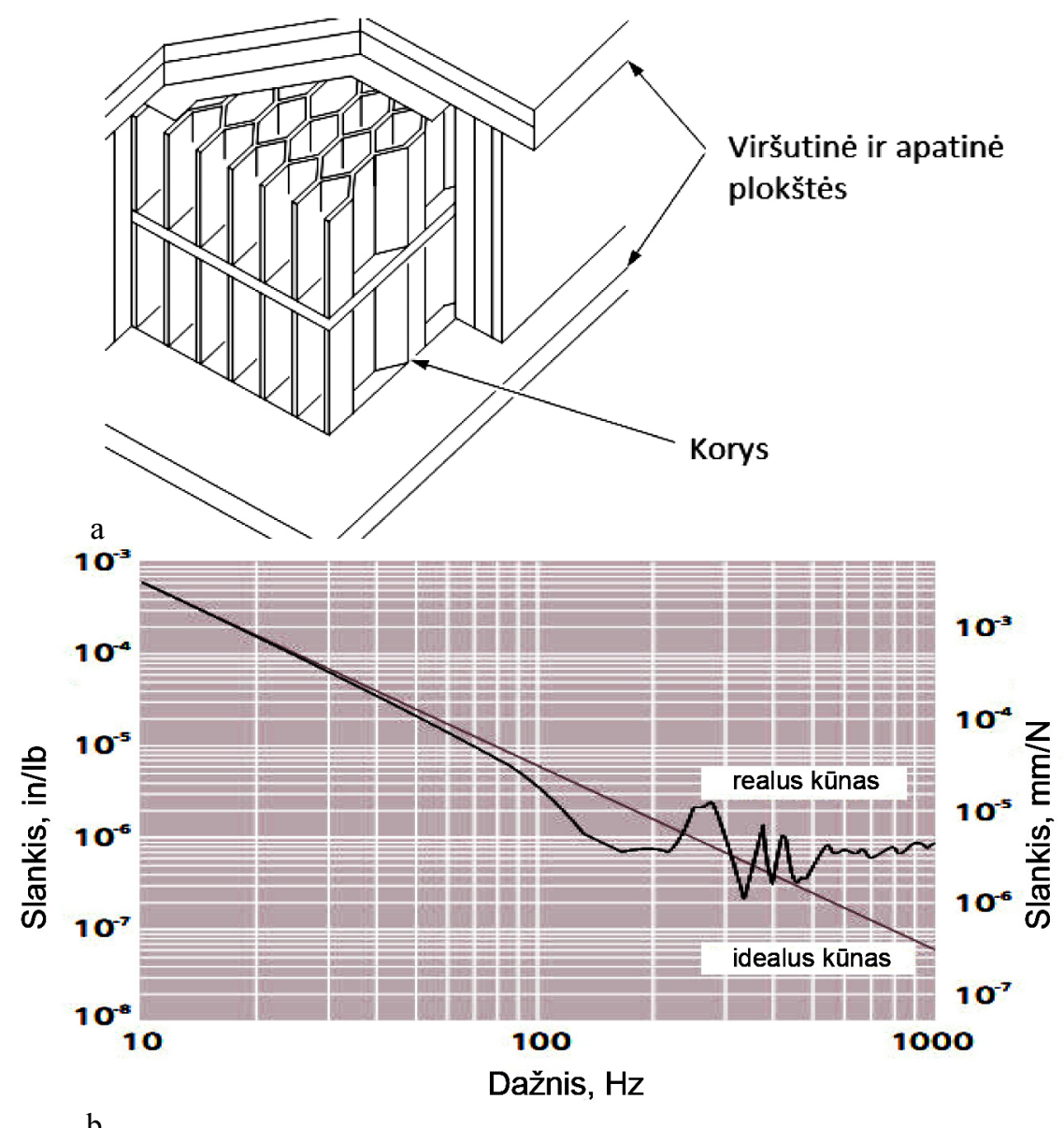

1.11 pav. Korinès konstrukcijos fragmentas (a) ir slankio kreivè (b)

(Fundamentals of vibration... 2009)

Fig. 1.11. Construction of a honoycomb panel (a) and a typical compliance curve (b)

(Fundamentals of vibration... 2009) 
Pneumatinio izoliatoriaus schema ir optinio stalo perduodamumo charakteristika parodyta 1.12 pav., a, b (Thorlabs 2012).

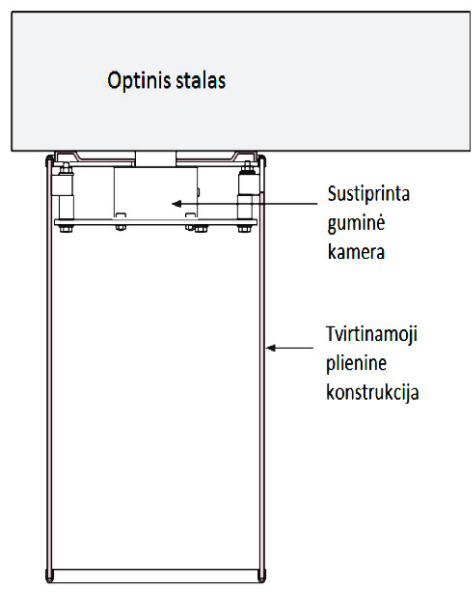

$\mathrm{a}$

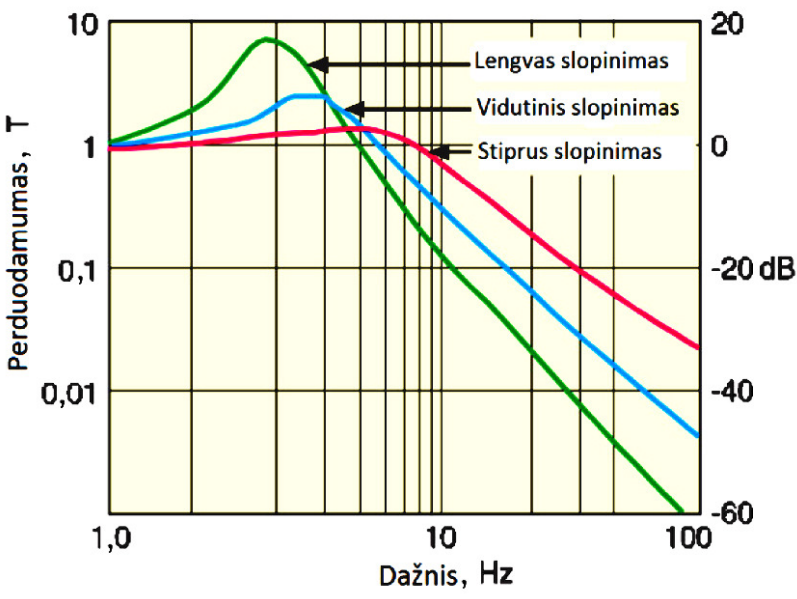

$\mathrm{b}$

1.12 pav. Pneumatinio izoliatoriaus schema (a) ir optinio stalo perduodamumas (b) (Thorlabs 2012)

Fig. 1.12. Air spring isolator (a) and transmissibility optical tabale (b) (Thorlab 2012)

Matome, kad atitinkamai sukonstravus optinę plokštę ir pneumatines atramas, naudojant naujas medžiagas ir šiuolaikines technologijas, galima gauti reikiamus slopinimus (1.12 pav., b) ir atitinkamus rezonansinius dažnius. Todèl tokių pasyviujų virpesių izoliavimo sistemų, naudojant naujas medžiagas, tobulinimas yra aktualus ir reikalingas.

\subsection{Pusiau aktyvios virpesių izoliavimo sistemos}

Nuo pat 1970 m., kai buvo sukurtos pirmosios pusiau aktyvios sistemos, jos buvo pradètos naudoti daugelyje inžinerijos sričiuc, ir kuo toliau, tuo daugiau jos naudojamos. Taip yra todèl, kad šių sistemu gebejjimas pasiekti puikias eksploatacines savybes yra didesnis negu klasikinių pasyviujų sistemų (Karnopp 1973; Krasnicki 1980). Pusiau aktyvios sistemos plačiai taikomos automobilių virpesiams izoliuoti, smūginiuose slopintuvuose, įvairių konstrukcijų virpesiams izoliuoti. Pirmine pusiau aktyvios sistemos strategija buvo siekiama sukurti slopinima, susijusi su masès inercija (skyhook sistemos), aprašyta kai kuriuose šaltiniuose (Crosly 1973; Karnopp 1974; Krasnicki 1980; Pan 1999, 2000). 
Tokia kontrolès strategija buvo pavadinta skyhook - pusiau aktyvia kontrole. Kai kurios pusiau aktyvių sistemų schemos parodytos 1.11 pav., a, b (Liu 2005).
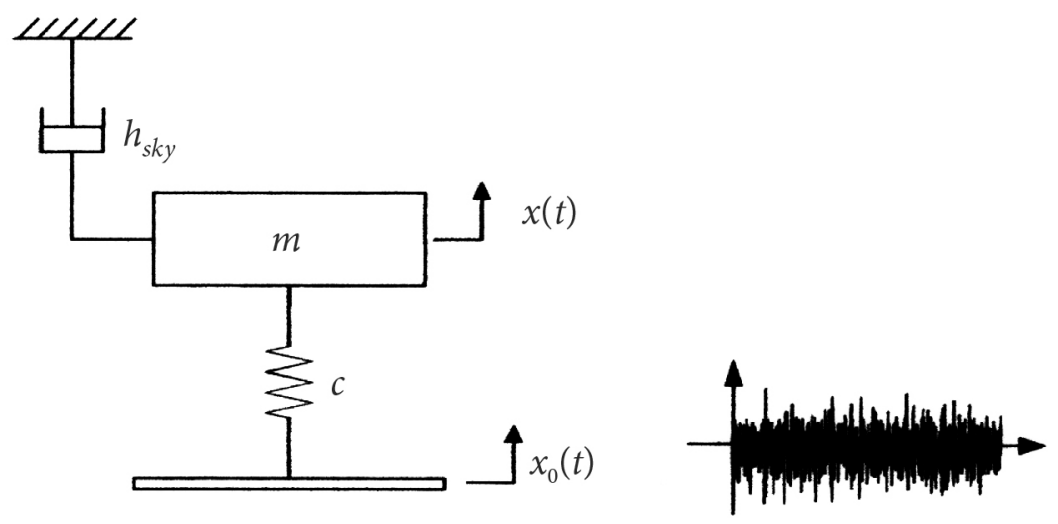

a

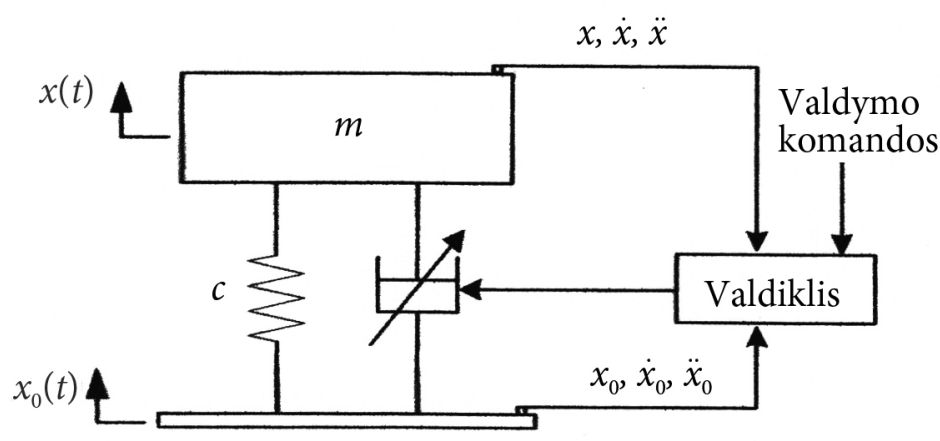

$\mathrm{b}$

1.13 pav. Pusiau aktyvios virpesių izoliavimo sistemos: a - skyhook strategija; b - slopinimo reguliavimo strategija (Pan 2000; Liu 2005)

Fig. 1.13. Semi-active systems: $a$ - skyhook; $b$ - semi-active damper (Pan 2000; Liu 2005)

Autorius (Karnopp 1974) studijavo pusiau aktyvias sistemas, kompiuteriu modeliuodamos harmoninius ir atsitiktinius žadinimus. Kompiuterinis modeliavimas buvo grindžiamas prielaida, kad pusiau aktyvų slopinimą veikianti jèga visada yra tolygi, nors praktikoje tai retai pasitaiko. Eksperimentiniais tyrimais Liu (2005) gavo perduodamumo reikšmes, atsižvelgdamas i dažni ir slopinimo koeficientą. Kartais tokios skyhook strategijos (Krasnicki 1980) siūlomos vadinti ,jungimas-išjungimas“ sistemomis (1.12 pav.). Tokios sistemos prisiima arba nulini slopinima, arba tik pastoviujų pasyviujų slopintuvų vertas. 
Ijungtos ir išjungtos skyhook sistemos schema parodyta 1.12 pav. su modifikuota perduodamumo lygtimi (Liu 2005; Chai 2001).

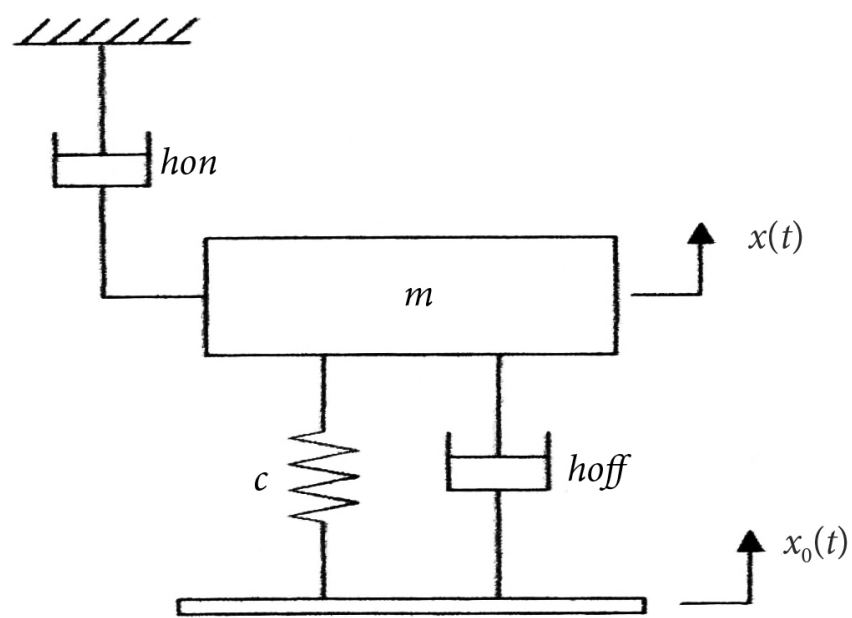

1.14 pav. Ljungta ir išjungta sistemos (Chai 2001)

Fig. 1.14. On-off system (Chai 2001)

Modifikuota perduodamumo lygtis:

$$
\mid H\left(\omega \mid=\left[\frac{1+\left[2 \xi_{\text {off }} \frac{\omega}{\omega_{n}}\right]^{2}}{\left[1-\left(\frac{\omega}{\omega_{n}}\right)^{2}\right]^{2}+\left[2\left(\xi_{\text {on }}+\xi_{\text {off }}\right)\left(\frac{\omega}{\omega_{0}}\right)\right]^{2}}\right]^{1 / 2} .\right.
$$

Jų perduodamumas atsižvelgiant ị dažnị ir slopinimą parodyta 1.13 pav.

Be to, šios sistemos nuo ankstesniujų skyhook sistemų skiriasi tuo, kad čia jègos slopinimas yra proporcingas santykiniam greičiui virš spyruoklių ir bespyruoklei masei, o ne absoliučiam masės greičiui virš spyruoklių. 


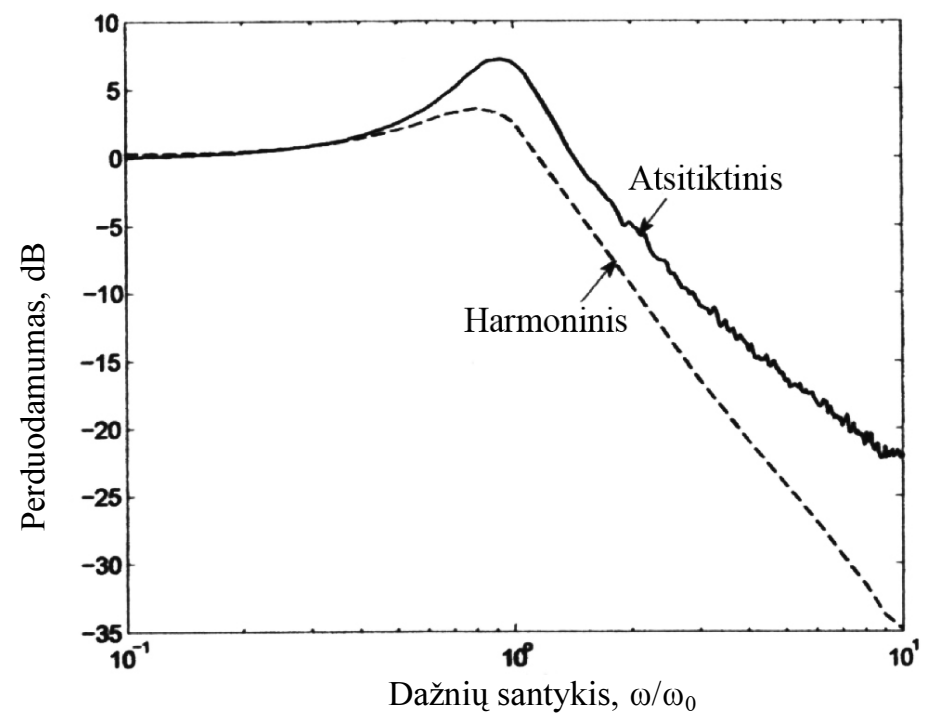

1.15 pav. RMS perduodamumas esant harmoniniam ir atsitiktiniam žadinimui (Liu 2005)

Fig. 1.15. RMS transmissibility to harmonic and disturbances for white acceleration input spectrum (Liu 2005)

Tokiu sistemų taikymo galimybès tiriamos transporto priemoniu pakabu sistemose. Ankstesniuose tyrimuose daugiausia buvo naudojamas skaitmeninis modeliavimas. Tačiau jis neleidžia fiziškai patikrinti visų gautų rezultatų. Egzistuoja tyrimu gausa su pusiau aktyviais slopintuvais virpesių kontrolei, tokių kaip transporto priemonių stabdymo arba pastato struktūros kontrolei, tačiau santykinai mažai mokslinių tyrimų, kur demesys buvo skiriamas žemo dažnio virpesių izoliavimui (Karnopp 1995; Alandy 1987). Nors naudojama vis daugiau sudètingu grižtamojo ryšio kontrolès strategijų, tikètina, kad naujai sukurtos neigiamo ir kvazinulinio standžio pasyvios virpesių izoliavimo sistemos dẻl savo labai aukšto izoliacijos efektyvumo leidžia virpesiams jautriai irangai, tokiai kaip zondinis mikroskopas, mikroskverbiklio testeris, profilio matuoklis ir skenuojantis elektroninis mikroskopas, veikti atšiauriausiomis sąlygomis ir smarkių virpesių aplinkoje kaip pavyzdžiui vakuume, aukštoje ir žemoje temperatūroje, veikiant radiacijai (Jim MacMahan 2011; Ferry 2007). Tokia aplinka pasitaiko, kai atliekami specifiniai tyrimai, pavyzdžiui šaldymo kameroje atliekami puslaidininkių tyrimai. 


\subsection{Aktyviosios virpesių izoliavimo sistemos}

Aktyvioji sistema būtų nebūtina, jei būtų galima gauti pasyviają sistemą su labai žemu savuoju dažniu, artejančiu prie nulio. Tačiau tokiai žemojo savojo dažnio sistemai bus būtinas toks žemas standumas, kad sistema negalès jo ilgiau išlaikyti. Todèl aktyvioji sistema tampa būtina virpesių izoliacijai vertikaliaja kryptimi. Žemojo dažnio virpesių izoliacija horizontaliaja kryptimi gali būti pasiekiama lengviau, turint žemą horizontalų standumą (Vijayan 2009).

Kadangi daugelis pasyviujų sistemų yra efektyvios ir pakankamos aukštujų dažnių virpesių izoliacijai, aktyviujų sistemų poreikis aukštujų dažnių virpesių izoliacijai yra mažesnis negu jų poreikis žemujų dažnių virpesių izoliacijai (Vijayan 2009). Be to, aktyvaus tipo virpesių izoliacinèms sistemoms reikia našių virpesių jutiklių, todèl jos yra apie dešimt kartų brangesnès nei pasyviojo tipo virpesių izoliacinès sistemos (Mizuno 2003).

Vieno laisvess laipsnio aktyviają virpesių izoliavimo sistemą (Sun 2007; Vijayan 2009), parodytą 1.14 pav., sudaro spyruoklè su standumo koeficientu $C$, slopintuvas su klampos koeficientu $H$, mase $M$ ir vykdiklis su kontrolès jèga $f_{a}$, sukeliantis žadinimo jèga $f_{s}$ ir sutelktos masès $M$ poslinkiu $x$.

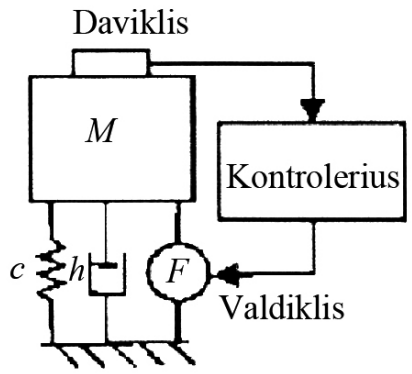

a)

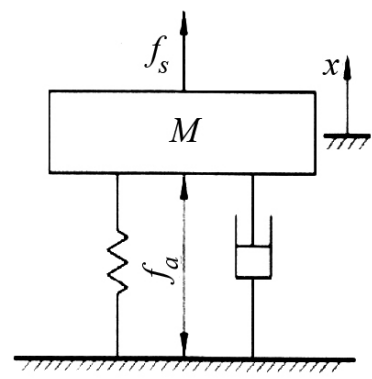

b)

1.16 pav. Aktyvioji virpesių izoliavimo sistema (a) ir jos dinaminis modelis (b) (Sun 2007)

Fig. 1.16. Active vibration isoliation system (a) and dynamics model (b) (Sun 2007)

$$
A_{f_{a}}=(C+j \omega H) A_{x}
$$

o pasyviosios sistemos:

$$
A_{x}^{\text {Pasyvi }}=\frac{1}{M \omega^{2}-\mathrm{C}-j \omega H} A_{f_{s}}
$$


čia $A_{f s}$ - žadinimo jègos $f_{s}$ sudètinè amplitudè; $A_{x}$ - poslinkio $x$ amplitudè.

Aktyviosios ir pasyviosios izoliacinių sistemų poslinkio amplitudès koeficientas yra toks: $\ddot{x}$

$$
a=\left|\frac{A_{x}}{A_{x}^{\text {Pasyvi }}}\right|=\left|\frac{M \omega^{2}-\mathrm{C}-j \omega H}{M \omega^{2}}\right|=\left|\frac{\left(\frac{\omega}{\omega_{0}}\right)^{2}-1-2 \xi \frac{\omega}{\omega_{0}} j}{\left(\frac{\omega}{\omega_{0}}\right)^{2}}\right|==\frac{\sqrt{\left(1-\Omega^{2}\right)^{2}+4 \xi^{2} \Omega^{2}}}{\Omega^{2}} .
$$

Čia $\omega_{0}=\sqrt{C / M}$ sistemos savasis dažnis, $\xi=H /(2 \sqrt{C M})$ izoliacinès sistemos slopinimo koeficientas ir $\Omega=\omega / \omega_{0}$ ra bematis žadinimo dažnis.

1.16 pav. pavaizduotos amplitudès $a$ poslinkio koeficientų kreivès esant ịvairiems dažniams ir ịvairiems slopinimo koeficientams. Esant mažesniems slopinimo koeficientams, aktyvioji izoliacinè sistema turi mažesnę poslinkio amplitudę nei pasyvioji sistema. Tačiau yra kritinis žadinimo dažnis, kuriam esant koeficientas yra didesnis už vieneta, ir amplitudès poslinkio koeficientas didejja sparčiai su mažejančiu dažniu. Todèl aktyvi izoliacija veiksmingai nesumažins masès virpesių ypač esant žemajam dažniui. Kadangi pasyvioji izoliacijos sistema suteikia gerą virpesių izoliacija, esant aukštojo dažnio virpesiams, aktyvioji izoliacijos sistema paprastai naudojama siekiant pagerinti virpesių izoliacija, esant žemiesiems dažniams. Todèl aktyviosios izoliacijos sistemos konstrukcijos tuo pačiu metu turi atitikti ir virpesių mažinimą, ir masès poslinkius.

Šalia tipinių aktyviujų virpesių izoliavimo sistemų yra sukurtos modifikuotos sistemos, siekiant išspręsti trūkumus, kuriuos sukelia didelis grižtamasis ryšys (Sun 2007).

Šiose sistemose vykdyklis yra nuosekliai sujungtas su minkštesnèmis spyruoklėmis ar mažesniu slopintuvu, kuris yra lygiagretus su spyruokle, kuri suteikia statini standumą ar kitoki slopinimą. Šiose sistemose vykdiklis pakeičia tik vieną ekvivalentišką standumą ir slopintuvą. Modifikuota aktyvioji virpesių izoliavimo sistema parodyta 1.16 pav. Yra du galimi valdiklio išdèstymo būdai - su spyruokle ir slopintuvu, kurie suteikia tas pačias dinamines charakteristikas. Palyginkime modifikuotą aktyviają virpesių izoliavimo sistemą su iprasta aktyviaja virpesių izoliavimo sistema.

Tokiai sistemai (1.16 pav.) dinaminè lygtis gali būti užrašyta taip:

$$
\begin{gathered}
M \ddot{x}+\mathrm{H} \dot{x}+\mathrm{Cx}=f_{a}+f_{s}, \\
f_{a}=h_{1} \dot{x}_{1}+c_{1} x_{1} .
\end{gathered}
$$




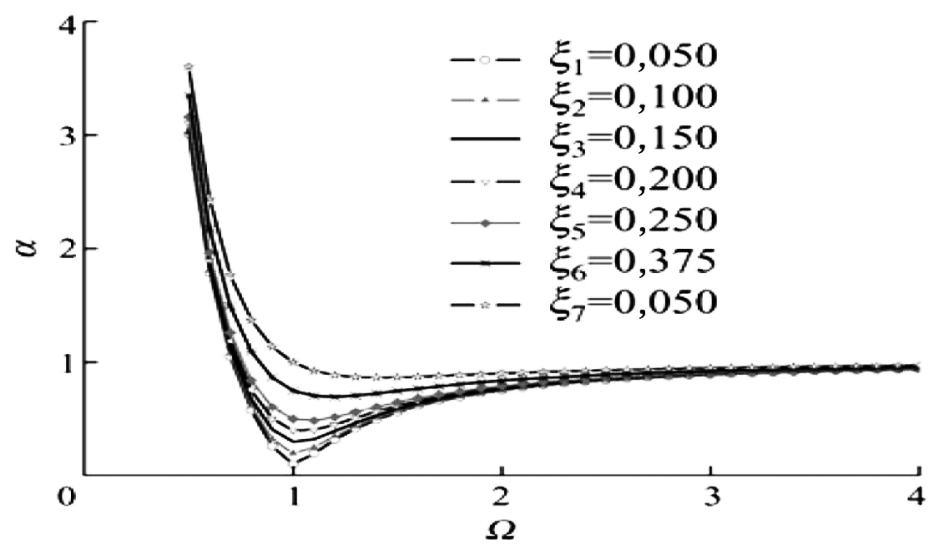

1.17 pav. Amplitudès poslinkiai, esant įvairioms dažnių ir slopinimo reikšmèms (Sun 2007)

Fig 1.17. Displacement amplitude ratios for various damping ratios (Sun 2007)

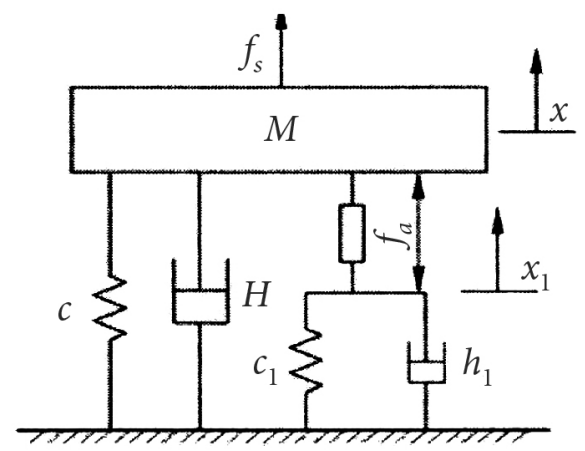

1.18 pav. Modifikuota aktyvioji virpesių izoliavimo sistema (Sun 2007)

Fig. 1.18. Modifed active isolation system (Sun 2007)

Greitis ir grižtamojo ryšio poslinkis lemia valdymo jèga, kuri yra:

$$
f_{a}=g_{v}\left(x-x_{1}\right)+g_{d}\left(x-x_{1}\right)
$$

čia $g_{v}-$ grižtamojo ryšio greitis; $g_{d}-$ grižtamojo ryšio poslinkis.

Matematinès analizès metodais nagrinėdamas modifikuotą aktyviają virpesių izoliavimo sistemą (1.16 pav.) Sun (2007) grižtamo ryšio poslinki ir greiti ivertina taip: 


$$
g_{d}=\frac{C c_{1}}{C-c_{1}}, \quad g_{v}=\frac{H h_{1}}{H-\mathrm{h}_{1}} .
$$

Apibrèždamas dviejų koeficientų parametrus $\beta=\frac{c_{1}}{C}$ ir $\gamma=h_{1} / H$, grị̌žtamojo ryšio parametrus jis užrašo taip:

$$
g_{d}=\frac{\beta}{1-\beta} C, g_{v}=\frac{\gamma}{1-\gamma} H .
$$

Modifikuotos aktyviosios virpesių izoliavimo sistemos palyginimas su tipine aktyviaja virpesių izoliavimo sistema pateiktas 1.1 lentelèje. Objektai dviejose sistemose turi tokią pačią poslinkio amplitudę ir abi sistemos turi identišką valdymo jèga. Tol, kol $\beta$ ir $\gamma$ yra didesni negu nulis ir mažesni negu 0,5 , poslinkio ir greičio grižtamojo ryšio kitimas (padidejimas) gali būti sumažintas iki norimos vertes pakoregavus $\beta$ ir $\gamma$. Tačiau grižtamojo ryšio kitimo santykis pateiktai sistemai ir tipinei aktyvių virpesių izoliavimo sistemai yra atvirkštinis dydis valdiklio eigos koeficientui. Taigi, grižtamojo ryšio kitimo mažinimas didina valdiklio eigą. Didelę valdiklio eigą sunku sukurti, taigi pateikta sistema privalo išspręsti problemas tarp grižtamojo ryšio kitimo ir valdiklio eigos. Todèl siūloma sistema negali sumažinti objekto poslinkio ir valdymo jègos, o grižtamojo ryšio kitimo apribojimas nèra visiškai išspręstas. Kadangi abi valdymo jègos ir vykdiklio eiga yra poslinkio funkcijos, todèl svarbu tobulinti aktyviąsias virpesių izoliavimo sistemas, siekiant sumažinti poslinkị.

Aktyviosios virpesių izoliavimo sistemos (1.15 pav.) yra tinkamesnès žemiesiems dažniams izoliuoti (Spanos et al. 1993; Nelson et al. 1991; Anderson et al. 1997; Jun et al. 1997; Ming-Chang Shih et al. 2008; Romallo et al. 2000), lyginant su klasikinemis pasyviosiomis virpesių izoliavimo sistemomis (1.6 pav.). Siūloma (Hehsley et al. 1999) naudoti aktyviąsias virpesių izoliavimo sistemas su rezonansiniu dažniu $0,033 \mathrm{~Hz}$ kartu su pasyviosiomis sistemomis, tokios sudètinès sistemos sumažina žalingą virpesių poveiki esant $0,1-100 \mathrm{~Hz}$.

1.17 pav. grafiškai pavaizduotas pasyviujų ir aktyviųu virpesių izoliavimo sistemu perduodamumas. Šioje diagramoje dažnis buvo nustatytas ties $5 \mathrm{~Hz}$, kuris dažnai pasitaiko pastatu virpesiuose. Dèl šios priežasties likusi amplitudè pasyviosios izoliacinès sistemos paviršiuje yra aukštesnè nei amplitudė ant pastato grindų. Aktyvioji sistema mažina grindų virpesius per visą dažnių diapazoną (Stobener 2009) (1.18 pav.). 
1.1 lentelè. Modifikuotos aktyviosios virpesių izoliavimo sistemos palyginimas su tipine aktyviaja virpesių izoliavimo sistema

Table 1.1. Comparison of an active modified vibration isolation system with a typical active vibration isolation system

\begin{tabular}{|l|c|c|}
\hline & Tipinè sistema & Modifikuota sistema \\
\hline $\begin{array}{l}\text { Izoliuojamo objekto } \\
\text { kompleksinè poslinkio } \\
\text { amplitude } A_{x}\end{array}$ & $-\frac{1}{M \omega^{2}} A_{f_{s}}$ & $-\frac{1}{M \omega^{2}} A_{f_{s}}$ \\
\hline $\begin{array}{l}\text { Valdymo jègos komplek- } \\
\text { sinè amplitudè } A_{f_{a}}\end{array}$ & $(C+j \omega H) A_{x}$ & $(C+j \omega H) A_{x}$ \\
\hline $\begin{array}{l}\text { Grižtamojo ryšio poslin- } \\
\text { kio padidèjimas }\end{array}$ & $C$ & $-\frac{\beta}{1-\beta} C$ \\
\hline $\begin{array}{l}\text { Grižtamojo ryšio greičio } \\
\text { padidejjimas }\end{array}$ & $H$ & $-\frac{\gamma}{1-\gamma} C$ \\
\hline Vykdiklio eiga & $\left|A_{x}\right|$ & $-\frac{\beta}{1-\beta}\left|A_{x}\right|$ \\
\hline
\end{tabular}

Aktyviosios sistemos atveju virpesiai gesta $0,3 \mathrm{~s}$, o pasyvioji sistema virpa beveik 2 s (Stobener 2009). Nepaisant aktyviuju virpesių izoliavimo sistemų spartaus vystymosi ir gautų žemujų dažnių virpesių izoliavimo gerų rezultatų, pastaruoju metu kuriamos naujo tipo visiškai mechaninès koncepcijos pasyviosios žemojo dažnio virpesių izoliavimo sistemos, kurios yra kompaktiškos, lengvai perkeliamos iš vietos i vieta, galinčios dirbti vakuume, aukštose ir žemose temperatūrose bei veikiant radiacijai, o aktyviosios virpesių izoliavimo sistemos to negali. Taigi pasyviosios ir aktyviosios virpesių izoliavimo sistemos turi savo nišą pramoneje ir tyrimo laboratorijose.

\subsection{Neigiamo standžio pasyviosios virpesių izoliavimo sistemos}

Jau beveik 40 metu pneumatiniai virpesių izoliatoriai daugiausia naudojami pramonejje, akademinès bendruomenès lazerių centruose ir mikroinžinerijos irenginiuose. Precizinis virpesių izoliavimo poveikis vis dideja mikroelektronikos gamyboje, pramoniniuose lazeriu ir optinèse sistemose bei atliekant biologinius tyrimus. Vadinamosios pasyviosios sistemos sulauke rimto iššūkio iš naujųjų neigiamo ir kvazinulinio standžio virpesių izoliavimo sistemų. Tokio tipo sistemu kūrimas ir tyrimai vyksta dèl didelio poreikio pramoneje ir mokslinèse 
laboratorijose, nes šių sistemu gebejjimas efektyviai izoliuoti virpesius įvairiomis ir net pačiomis sunkiausiomis sąlygomis yra labai didelis (Berba 2012; Jim McMahon 2011; Ferry 2007; Platus 1999).

Aktyviosios virpesių izoliavimo sistemos sudetingomis aplinkos sąlygomis negali užtikrinti tinkamo izoliavimo.

Neigiamo standžio izoliatoriai naudoja visiškai mechaninę koncepciją žemojo dažnio virpesių izoliacijai. Vertikaliosios eigos izoliaciją užtikrina standi spyruoklè, kuri kartu su neigiamo standžio mechanizmu atlaiko svorio spaudimą (1.19 pav., a).

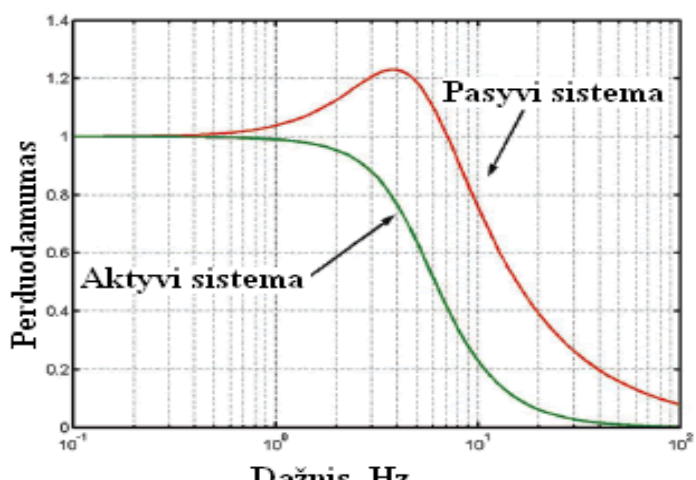

Dažnis, $\mathrm{Hz}$

1.19 pav. Pasyviujų ir aktyviujų virpesių izoliavimo sistemų teorinis perduodamumas (Stobener 2009)

Fig. 1.19. Theoretical transmissibility of passive and active vibration isolation systems (Stobener 2009)

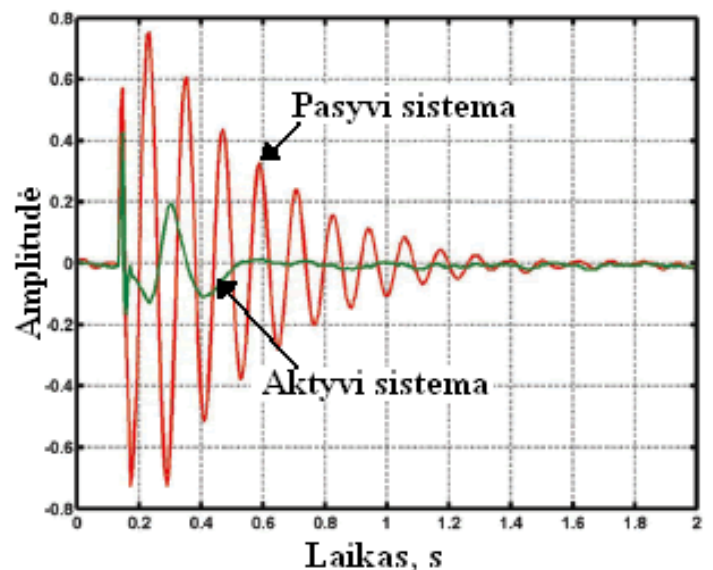

1.20 pav. Pasyviosios ir aktyviosios sistemų virpesių gesimo laikas po poveikio

(Stobener 2009)

Fig. 1.20. Time of vibration decaying of passive and active systems after an impact

(Stobener 2009) 

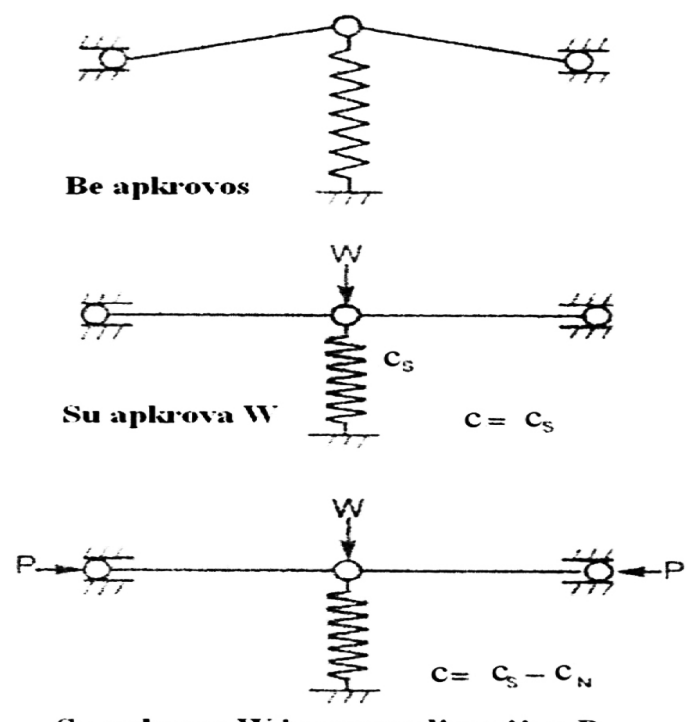

Su apkrova $\mathbf{~}$ ir suspaudimo jèga $P$

a
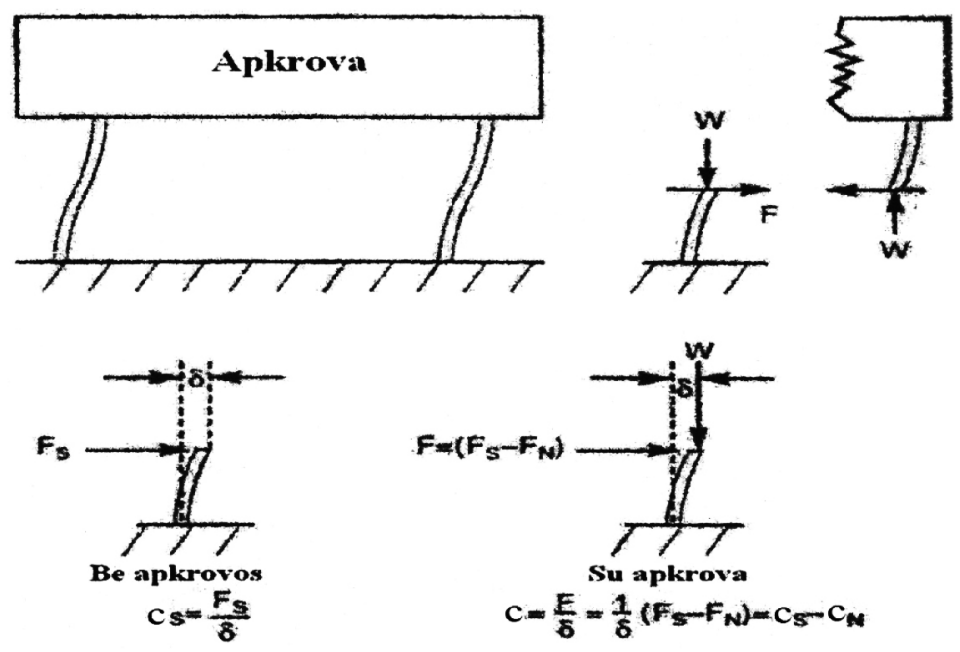

b

1.21 pav. Neigiamo standžio mechanizmas, kuris sumažina pasyviosios sistemos savaji dažnị: a - vertikaliujų virpesių izoliavimo principas; b - horizontaliujų virpesių

$$
\text { izoliavimas (Platus 1993, 1999) }
$$

Fig. 1.21. Mechanism of a negative stiffness which decreases the self frequency of the passive system: $a$ - principal of isolation of vertical vibrations; $b$ - isolation of horizontal vibrations (Platus 1993, 1999) 
Neigiamo standžio izoliatoriai naudoja vieną sistemą, kad izoliuotų naudingąsias apkrovas nuo vertikalaus judejjimo, ir kitą kad apsaugotu irangą nuo horizontaliujų poslinkių. Abi sistemos naudoja neigiamo standumo mechanizmą, kad išlaikytų bendrą standuma, taigi ir žemą rezonansini dažnį. Mechanizmai šiek tiek skiriasi kiekviena judejjimo kryptimi (McMahon 2009).

Vertikaliaja kryptimi standi spyruoklè palaiko naudingosios apkrovos svori (1.19 pav., a). Standžios sistemos turi rezonansinius dažnius ir yra linkusios perduoti daugiau virpesių i apkrova, todèl neigiamo standžio mechanizmai, statmeni spyruoklių ašims, sumažina visą standị (McMahon 2009).

Rezultatas - kompaktiškas pasyvus izoliatorius, gebantis slopinti labai žemus vertikaliuosius ir horizontaliuosius savuosius dažnius ir aukštus vidinius konstrukcinius dažnius. Izoliatoriai (sureguliuoti esant $1 / 2 \mathrm{~Hz}$ ) pasiekia $93 \%$ izoliacijos efektyvuma, kai dažnis yra 2 Hz; 99 \%, kai dažnis yra 6 Hz; 99,7 \%, kai dažnis yra $10 \mathrm{~Hz}$ (McMahon 2009).

1.20 pav. pateiktos neigiamo standžio ir optinio stalo virpesių izoliavimo sistemų tipinès perduodamumo kreivès (Platus 2007).

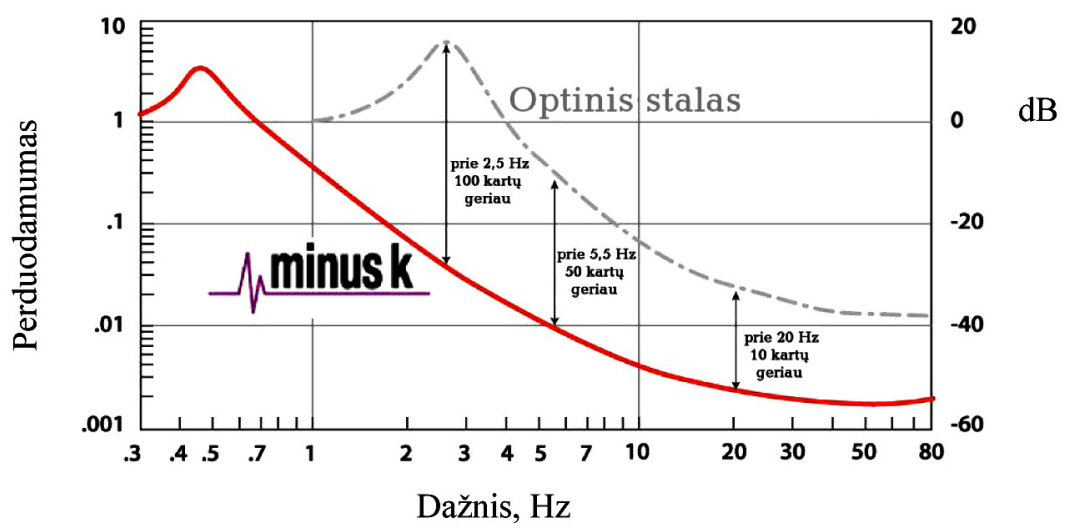

1.22 pav. Neigiamo standžio virpesių izoliavimo sistemos tipinės perduodamumo kreivejs, palyginti su aukščiausių charakteristikų optinio stalo perduodamumu (Platus 2007; McMahon 2011)

Fig. 1.22. Typical transmissibility curves of vibration isolation system of the negative stiffness compared with the transmissibility of an optical tabale of the highest characteristics (Platus 2007; McMahon 2011)

Pasyvieji žemojo dažnio virpesių izoliatoriai yra šiek tiek jautrūs nedideliam svorio pokyčiui ir dideliems poslinkiams. Ši problema sušvelninama, kai neigiamo standžio sistema dedama ant optinio stalo be pneumatinių virpesių izoliatorių (JMcMahon 2009). 
Zondiniai mikroskopai turi specialius virpesių izoliavimo reikalavimus, kurie yra unikalūs metrologijos pasaulyje. Jie yra jautrūs ir vertikaliesiems virpesiais, ir horizontaliesiems, kad būtų pasiektas mažiausias įmanomas poveikis nuo grindų angstremų lygiu. Šiuo metu naudojamos neigiamo standžio virpesių izoliavimo sistemos (1.22 pav.), kurios teikia didesnį izoliavimo efektyvumą negu kitos sistemos ir šiam efektui pasiekti nereikia jokių papildomų priemonių.

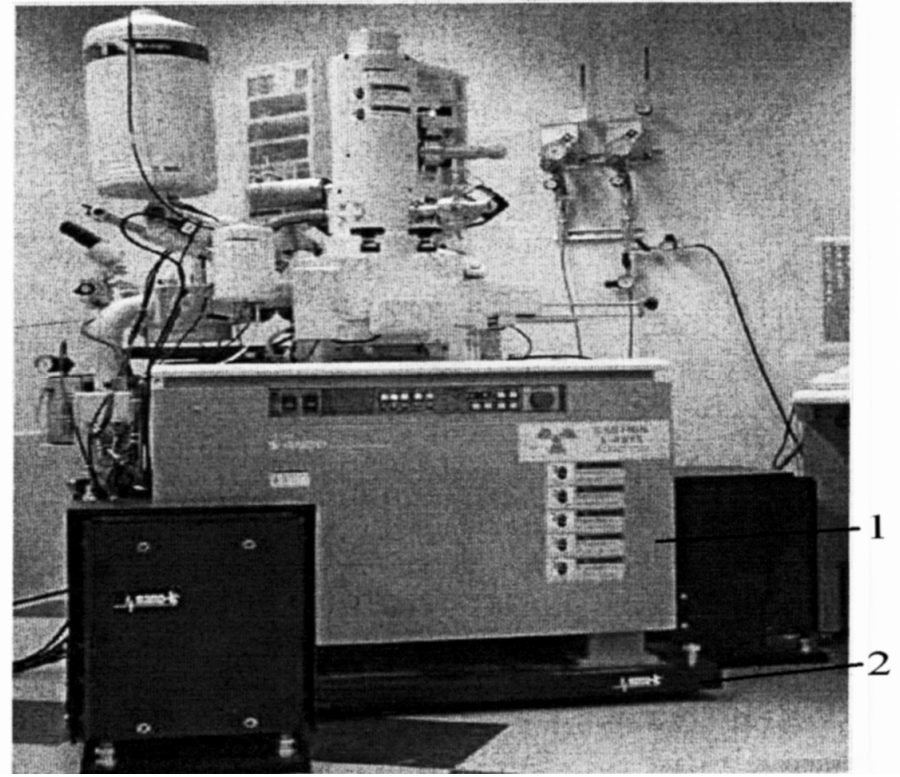

a

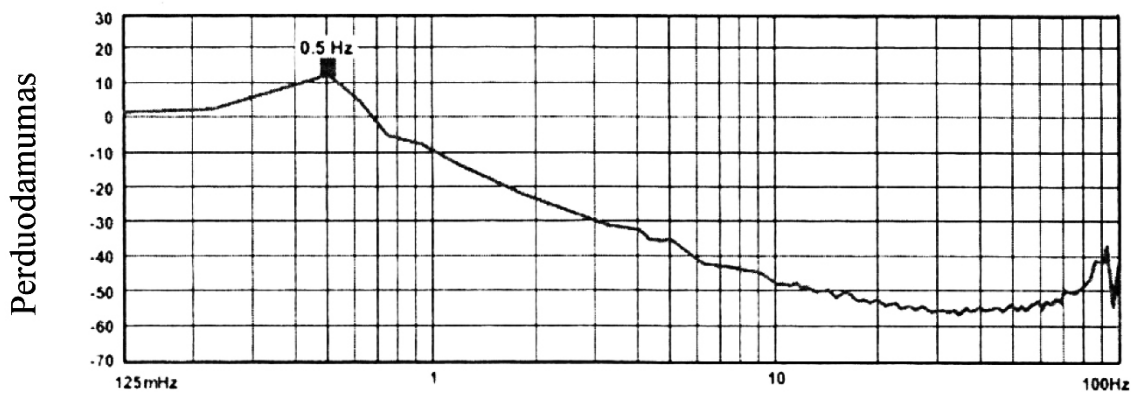

Dažnis, $\mathrm{Hz}$

b

1.23 pav. Elektroninis mikroskopas 1 (a), pastatytas ant neigiamo standžio virpesių izoliavimo sistemos 2, ir jos perduodamumo kreivè (b) (McMahon 2009)

Fig. 1.23. Electronical microscope 1 (a) set on the vibration isolation system of negative stiffness 2 and curve of its transmissibility (b) (Jim McMahon 2009) 
1.24 pav. parodytas spektrinès galios tankis auginant kristalus gama spindulių spektrometru, kai naudojama neigiamo standžio sistema ir kai nenaudojama (McMahon 2011).

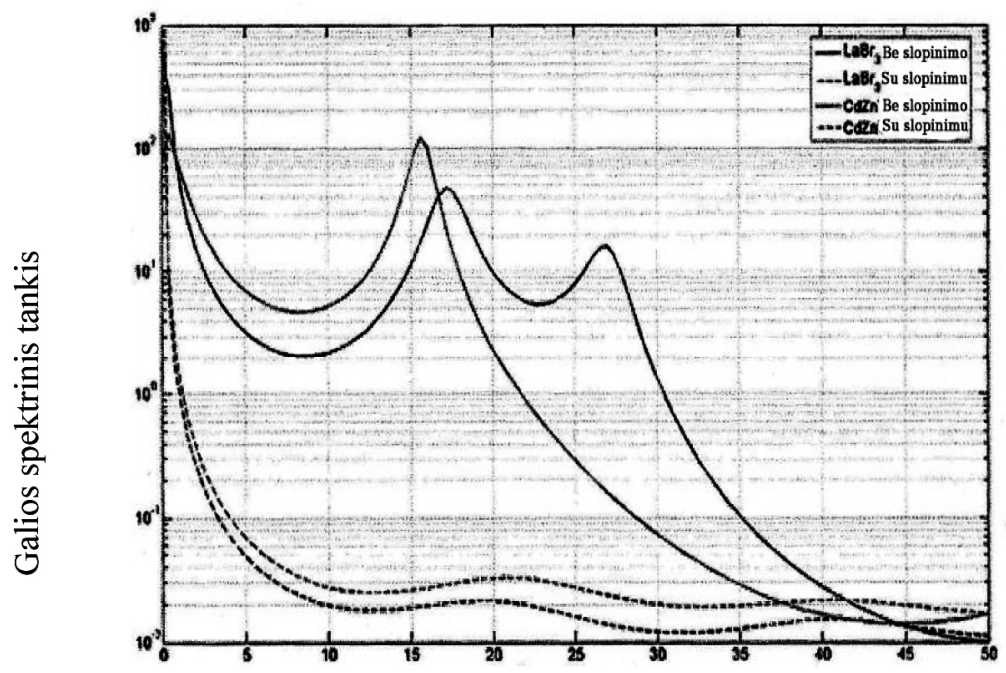

Dažnis, $\mathrm{Hz}$

1.24 pav. Spektrines galios tankis: ištisinès linijos - be virpesių izoliavimo; punktyrinès - su virpesių izoliavimu (McMahon 2011)

Fig. 1.24. Dencity of spectral power: solid lines - without isolation of vibrations; dashed lines - with isolation of vibrations (Jim McMahon 2011)

Visos metalinès neigiamo standžio sistemos ir konstrukcijos gali būti konfigūruojamos taip, kad atlaikytų aukštą vakuumą ir kitas šiurkščias aplinkas, tokias kaip aukštą ir žemą temperatūrą bei radiaciją. Pavyzdžiui, neigiamo standžio izoliatoriai gali būti naudojami tiesiai vakuuminèje kameroje. Toks naudojimo būdas suteikia ir kitų pranašumų, pavyzdžiui, daug mažesnis naudingasis svoris, kompaktiškesne sistema, ir pašalina problemas, susijusias su vakuumo kameros naudojimu.

\subsection{Kvazinulinio standžio pasyvioji virpesių izoliavimo sistema}

Daugelis žinomų specialių virpesių izoliavimo sistemų pasižymi tuo, kad mažindamos žemujų dažnių sistemos virpesių rezonansus jos nepakankamai užtikrina tai, esant aukštesniems virpesių dažniams. 
Toks mechaninès virpesių izoliavimo sistemos trūkumas būdingas aprašytai tarptautinèje patentinejje paraiškoje PCT/US/90/04608, paskelbtoje kaip W091/02921 „Schwingungsisoliations system“. Joje pateikiama mechaninè virpesių izoliavimo sistema pritaikoma virpesiams slopinti, kai mažas nestabilumas vyrauja ašine kryptimi, o tai bendruoju atveju yra objekto išdèstymo platformos apkrovos kryptis, t. y. vertikali kryptis. Tas yra pasakytina apie bet kurią kitą skersinę minètajai krypti, kuri yra horizontali kryptis. Aprašomoje virpesių izoliavimo sistemoje panaudota izoliatorių (slopintuvu) kombinacija, kurioje ašine kryptimi išdèstyti izoliatoriai (slopintuvai) vienas su kitu taip susiję, kad pasiruošę slopinti įvairiakrypčius virpesius. Slopintuvai taip įrengti ir išdèstyti, kad arba ašinių, arba skersinių bet kokios krypties virpesių komponentų sukeltus poslinkius slopina. Taip veikdami slopintuvai užtikrina visų krypčių virpesių slopinimą. Šiame aprašyme ašiniai slopintuvai vadinami vertikaliais, o skersiniai - horizontaliais, o pati koncepcija - naujoviška. Su tuo galima sutikti, nes, peržvelgus ankstesnius analogus, tokios kokybès virpesių izoliavimo sistemos nepavyko aptikti, o ir vèlesni išradimai patvirtina koncepcijos naudojimo efektyvuma, praktinę jos reikšmę.

Kartu reikia pažymèti, kad teorinis jų pagrindimas anksčiausiai buvo paskelbtas profesoriaus P. M. Alabuževo dar $1967 \mathrm{~m}$. Tai, kas praktikoje pagal aprašytą tarptautinèje paraiškoje WO94/13999 virpesių izoliavimo sistemą vadinama neigiamu standžiu - negatyve stiffness, profesorius P. M. Alabuževas, numatydamas tamprių sistemų naudojimą dinaminių objektų virpesiams izoliuoti, ivardijo kaip kvazinulini standị. Tai grindžiama vẻlesniuose rusų mokslininkų darbuose (Zotov 2005). Kvazinulinio standžio sąvoka grindžiama tuo, kad įveržtoje tampriojoje sistemoje grąžinančios i pradinę padèti jègos priklausomybė nuo poslinkio yra sinusoidiška (1.26 pav.) ir tam tikroje mažoje atkarpoje - tiesinè (1.26 pav.), o pačios atkarpos dydis dar priklauso nuo itemptų ir grąžinančių tampriujuc elementų išdèstymo kampų (1.25 pav.). Parenkant pagal tai atitinkamą masę ši statinejje padetyje apsaugoma nuo virpesių masé gali būti palaikoma spyruoklių su kvazinuliniu standžiu.

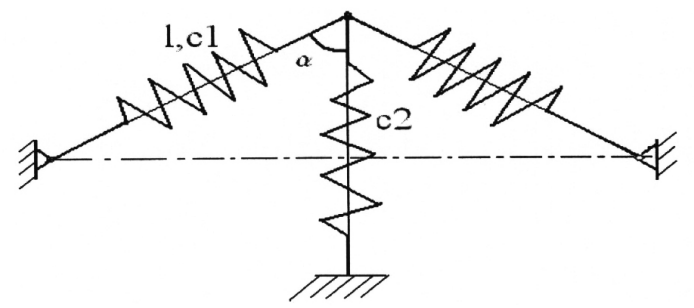

1.25 pav. Virpesiu izoliavimo sistema: $c_{1}, c_{2}$ - spyruokliu standis; $\alpha$ - kampas tarp spyruokliu; $l$ - ilgis (Zotov 2005)

Fig. 1.25. System of vibration isolation: $c_{1}, c_{2}-$ stiffness of springs; $\alpha$ - angle between the springs; $l$-length (Zotov 2005) 


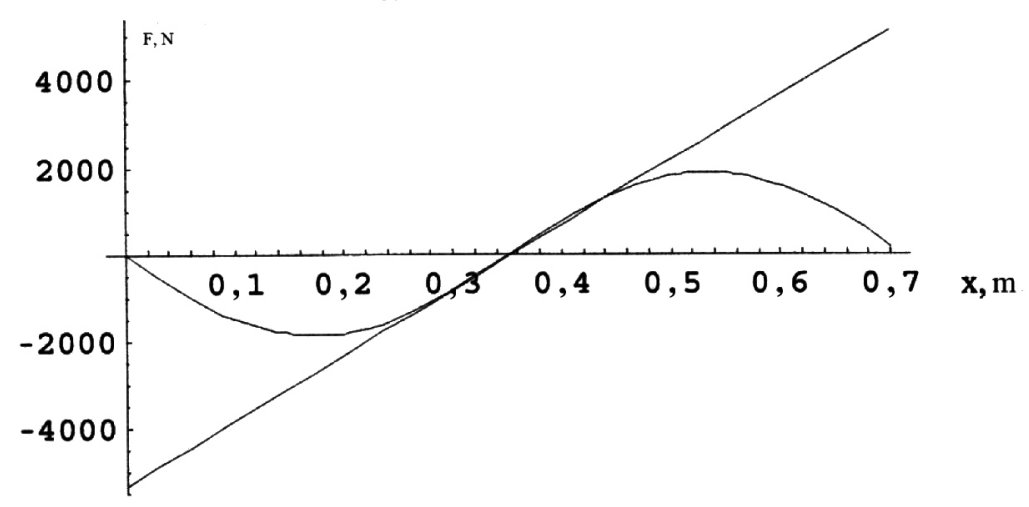

1.26 pav. Jègos priklausomybè nuo poslinkio (Zotov 2005)

Fig. 1.26. Dependence of force on displacement (Zotov 2005)

Tarptautineje paraiškoje WO94/13999 aprašyta nepriklausoma nuo apkrovos i objektą išdèstymo pagal apskritimą virpesių izoliacinès pakabos sistema apima daugeli mišrių (bendrai veikiančių) virpesių izoliatorių, spyruokliuojančiai palaikančių ir izoliuojančių nuo virpesių objektą ant darbinio naudojimo platformos. Kiekvienas mišrus izoliatorius, sudarytas iš vertikalaus poslinkio izoliatoriaus, tuo pat metu yra dinamiškai susijęs su horizontalaus poslinkio izoliatoriumi, o vertikalaus judesio amortizatorius turi atraminę spyruoklę, kuri koncentriška ìvorei ir per ją susieta su pagrindo platforma. Vienas atraminès spyruoklès irenginio galas naudojamas pozityviam irenginio standžiui ašine kryptimi ir apkrovai nuimti, kurią sukuria darbinio naudojimo platforma, taip pat yra numatytas pakabos izoliatorius, nuimantis darbinès platformos apkrovą ir suteikiantis neigiamą standi ašine kryptimi. Atraminès spyruoklès įrenginys, veikdamas su minètu pakabos izoliatoriumi, sukelia mažą vertikalų sistemos standi.

Neigiamo standžio mechanizmas, itaisytas įvorès viduje, veikia priešingai pozityvaus standžio mechanizmui. Horizontalaus poslinkio amortizatorius sudarytas iš trijų lanksčių virbų, susijusių su vertikalaus poslinkio izoliatoriumi.

Artimiausias pateikiamam išradimui techninis sprendimas aprašytas patente US 5833204. Objekto, irengto ant darbinio naudojimo platformos, virpesius sukeliančias vertikalias ir horizontalias virpesių komponentes slopina mišrių (bendrai veikiančių) virpesių izoliatorių sistema.

Vertikalaus poslinkio amortizatorius susideda iš pozityvaus standžio mechanizmo, turinčio atraminès spyruoklès pavidalą, ir išdèstyto įrenginio centre, kurios vienas galas susietas su centre sumontuoto strypo atraminiu paviršiumi, o kitas galas veikia įrenginio viduje sudètingai išdèstytą svertų sistemą, sudarytą iš horizontalių ir pasvirai vertikalių standžiujjų strypų, kurie poslinkio metu defor- 
muoja vienas kitą. Strypai turi savybę ne tik atsverti ašinę spyruoklès jègą, bet ir redukuoti radialinius objekto virpesius, dèl to išorinis įrenginio korpusas susiejamas su darbine platforma. Jai stabilumo suteikia korpusas, standžiai suveržtas horizontaliai. Radialiniai objekto illinkiai blokuojami svertų deformaciją atitinkančia jègu atstojamaja, kuri redukuoja jègos komponentus, sužadinančius tiek vertikaliuosius, tiek horizontaliuosius virpesius. Pagrindinis aprašytos sistemos trūkumas tas, kad taip atsirandančiu jègų pusiausvyrai užtikrinti kiekvieno iš svertu jègu petys turi būti didelis, o vertikaliai pasvirusių strypu posvyrio kampas mažas. Be to, darbingumui užtikrinti reikalingų svertų deformacijos reguliuojamos sudètingai ir ilgai. Apibendrinant darytina išvada, kad radialiniai objekto nuokrypiai redukuojami proporcingai išilginiam nuokrypio dydžiu. Kadangi šio išradimo tikslas - redukuoti radialinius nuokrypius, reikia tiksliai išcentruoti objekto masę. Tai pagrindinis aprašyto patento trūkumas.

Patentas grindžiamas tuo, kad įveržtoje tampriojoje sistemoje grą̌inančios i pradinę padèti jègos priklausomybè nuo persislinkimo yra sinusoidiška (1.26 pav.). Kaip žinoma, sin $0^{\circ}=0$. Pateikiamoje mechaninejje virpesių izoliacineje sistemoje, iveržtoje vertikaliomis ir horizontaliomis spyruoklemis, kai iveržtumą palaiko vertikalių ir horizontalių svertų sistema, grąžinančių i pradinę padèti jègų atstojamoji kaip tik ir susideda iš artimų $0^{\circ}$ vertikaliam ir horizontaliam pokrypiams svertų deformacijų. Tai labai mažame persislinkimų diapazone užtikrina kvazinulini sistemos standị. Be abejo, tas persislinkimų diapazonas susijęs ir su objekto mase, per objekto padèklą veikiančia atramines spyruokles. Skirtingoms masèms jos turi būti apskaičiuojamos atskirai. Jègų pusiausvyrą lemiantys vertikalūs standūs svertai yra keturi ir išdèstyti vienodu atstumu nuo centrinio strypo ašies. Dèl to galima tame keturkampyje įrengti objektą ant padèklo nutolusioje nuo centro vietoje, ne tik sutapdinant masių centrą su centrinio strypo ašimi. Galinti dèl to atsirasti padèklo horizontaluji pokrypi redukuoja speciali padèklo pakaba (1.27 pav.).

1.27 paveiksle pavaizduotos virpesių izoliavimo sistemos konstrukcijos pagrindas yra bazinè plokštė 19, ant kurios tvirtinami atraminiai stovai, viršutinis 39 ir apatinis 20 , turintys atramines reguliuojamąsias kojeles 28 . Tokių atramu sistemoje gali būti trys ar keturios, atsižvelgiant ị konkretaus įrenginio pajègumą. Bazinès plokštès 19 centre išsidèstęs centrinès atraminès spyruoklès 26 reguliavimo mechanizmas, susidedantis iš sliekračio tvirtinimo įvorès 24 su sriegine kolonėle, kuri laisvai pasisuka bazinès plokštès 19 skylèje. Prie ịvorès 24 pritvirtintas centrinès atraminès spyruoklès mechanizmo sliekratis 23 ir centriné srieginè ịvore 25 , turintys apsaugą nuo prasukimo vienas kito atžvilgiu. 


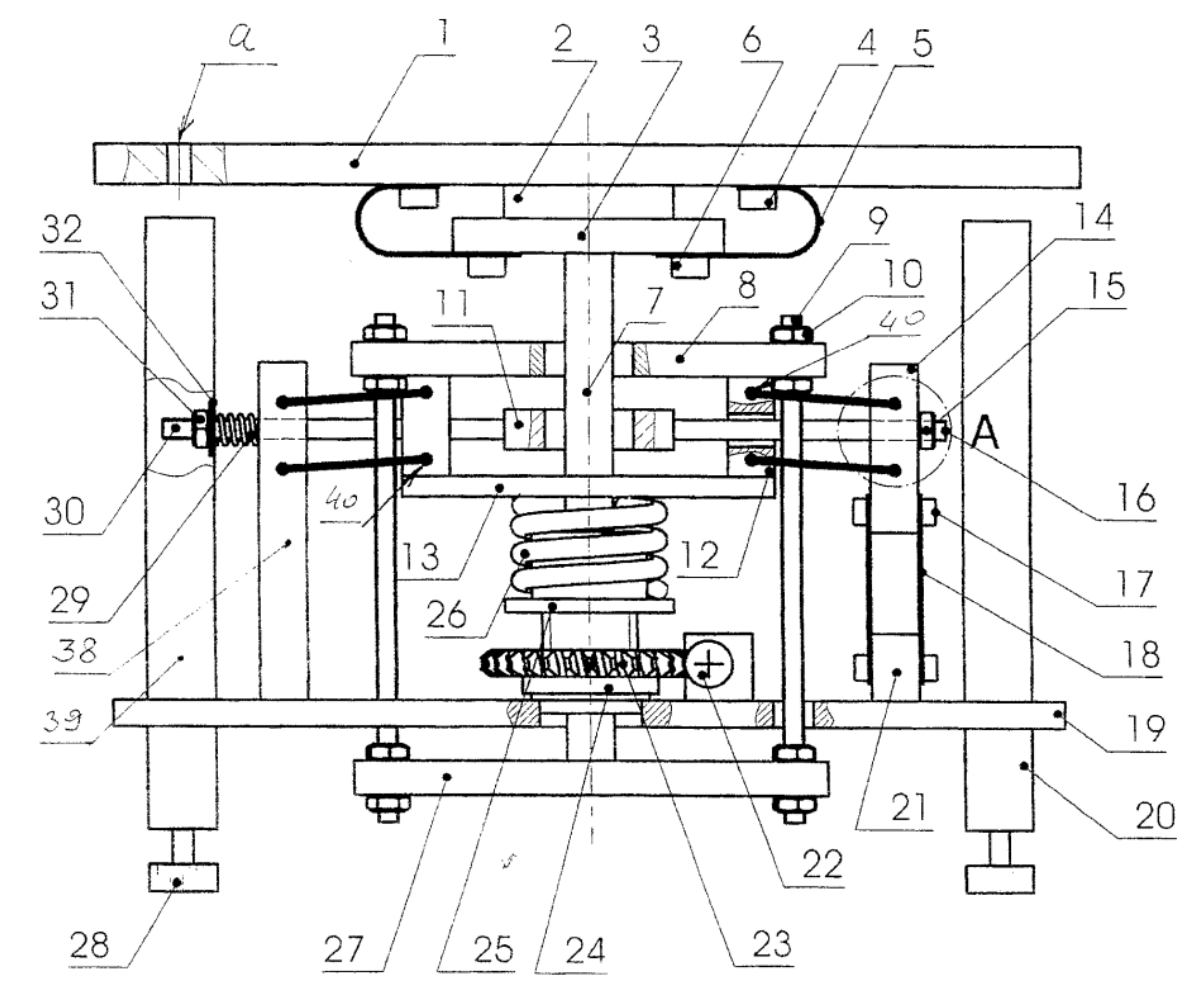

$\mathrm{a}$

$\mathrm{b}$

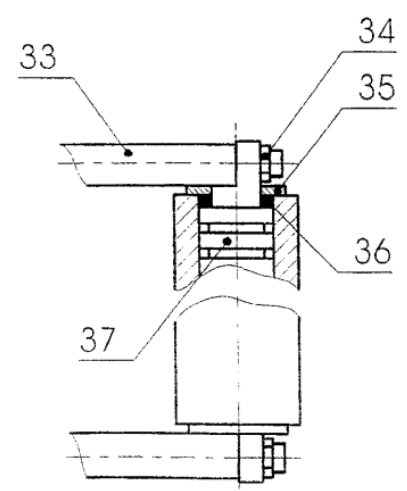

1.27 pav. Naujos konstrukcijos kvazinulinio standžio virpesių izoliavimo sistema (a) ir pjūvis (b): 1 - objekto padèklas; 2 - pokrypio virpesių izoliatorius; 3 - viršutinè atraminè plokštė; 4 - tvirtinimo fiksatorius; 5 - pokrypio slopintuvas; 6 - tvirtinimo fiksatorius; 7 - centrinis strypas; 8 - viršutine slopinimo bloko plokštė; 9 standus pakabos strypas; 10 - veržlè; 11 - centrinè îveržimo sraigto dalis; 12 - horizontalaus slopinimo sistemos korpusas; 15 - iveržimo sraigto paslankus slopintuvų korpusas; 16 - srieginis įveržimo sraigto galas; 17 plokščių spyruoklių tvirtinimo plokštelè; 18 - paslankaus slopintuvų bloko plokščios spyruoklès; 19 - bazinè plokštė; 20 - apatinis atraminis stovas; 21 - plokščiu spyruoklių tvirtinimo korpusas; 22 - sliekas su atraminès spyruoklès mechanizmo korpusu; 23 - atraminès spyruoklès mechanizmo sliekratis; 24 - sliekračio tvirtinimo ịvorè su sriegine kolonėle; 25 - atraminè srieginè įvorè; 26 - centrinè atraminè spyruoklè; 27 apatinè slopinimo bloko plokštė; 28 - atraminè reguliuojama kojelè; 29 - horizontali slopinimo bloko spyruoklè; 30 - îveržimo sraigtas; 31 - horizontalios spyruoklès regu- 
liavimo veržlè; 32 - poveržlè; 33 - horizontalūs slopinimo bloko strypai; 34 - horizontalaus strypo tvirtinimo veržlè; 35 - poveržlè; 36 - tarpinè; 37 - hidraulinio slopintuvo ašis su grioveliais, užpildytais silikoniniu skysčiu; 38 - nejudamas slopintuvų korpusas; 39 - viršutinis atraminis stovas; 40 - ašis; a - padèklo tvirtinimo transportuoti skylè (Berba 2012)

Fig. 1.27. New design of the vibration isolation system of quasi-zero stiffness (a) and a layer (b): 1- cushion of the object; 2 - isolator of inclination vibrations; 3 - upper support plate; 4 - locking pin; 5 - damper of inclination; 6 - locking pin; 7-central rod; 8 - upper plate of a damper block; 9 - stiff rod of the hanger; 10 - nut; 11- central part of an adjuster; 12 - body of a system of horizontal damping system; 15 - mobile body of dampers of an adjuster; 16 - threaded end of an adjuster; 17 - fixing plate of plane springs; 18 - plane plates of a movable damping block; 19 - basic plate; 20 - lower supporting stand; 21 - fixing plate of plane springs; 22 - worm with the body of supporting spring mechanism; 23 - worm wheel of mechanism of the supporting spring; 24 bushing of worm wheel fixing with a threaded column; 25 - supporting screw bushing; 26 - central supporting spring; 27 - horizontal spring of of a damper block; 28 - adjustable supporting leg; 29 - horizontal spring of damping block; 30 - adjuster; 31 - adjusting nut of horizontal spring; 32- washer; 33 - horizontal rods of a damping block; 34 fixing nut of a horizontal rod; 35 - washer; 36 - silencer; 37 - axis of hydraulic damper with the groves filled with silicon fluid; 38 - non movable body of dampers; 39 - upper supporting stand; 40 - axis; a- hole of pallet fixing for transportation (Berba 2012)

Sliekratis 23 sukabintas su slieku 22, sumontuotu korpuse, standžiai sujungtu su bazine plyta 19. I ivvorę 25 remiasi atraminè spyruokle 26. I spyruoklę 26 remiasi slopinimo blokas, sudarytas iš detalių 8,12 (du vienetai) ir 13 . Ant viršutinès slopinimo bloko plokštès 8 veržlèmis 10 pritvirtinti keturi standūs pakabos strypai 9, prie kurių apatinių galų veržlèmis 10 pritvirtinta apatinè slopinimo bloko plokšte 27 . Jos centre prie plokštès 27 standžiai pritvirtintas centrinis strypas 7, kuris laisvai pralenda per ịvorès 24 skylę. Skylès skersmuo užtikrina galimą strypo pokrypi. Ant viršutinio centrinio strypo galo standžiai pritvirtinta viršutinė atraminè plokštė 3, kuri su objekto padèklu 1 jungiasi per pokrypio virpesių izoliatorių 2 ir du-keturis pokrypio slopintuvus 5 , pritvirtintus prie objekto padèklo 1 ir plokštès 3 atitinkamai tvirtinimo fiksatoriais 4 ir 6 . Ant bazinès plokštumos 19 taip pat yra pritvirtinti slopinimo bloko korpusai 38 ir 14 . Korpusas 38 nejudamas ir standžiai sutvirtintas su bazine plokšte 19, o korpusas 14 prie plokštès 19 pritvirtintas plokščiomis spyruoklèmis 18, kurios iš vienos pusės pritvirtintos prie korpuso 14, o iš kitos - prie spyruoklių 18 tvirtinimo korpuso 21, standžiai sujungto su bazine plokšte 19. Spyruoklès 18 pritvirtintos plokštelemis 17. Korpusas 38 ir paslankus korpusas 14 tarp savęs glaudžiai sujungti îveržimo sraigtu 30, kuris savo srieginiu galu 16 veržlèmis 15 fiksuotas prie paslankaus korpuso 14. Ant priešingo sraigto 30 galo uždèta horizontali spyruoklè 29, per poveržlę 32 pritvirtinta veržle 31 . 
Iveržimo sraigtas 30 susideda iš trijų daliu, iš kuriu kraštinès sraigto 30 viduryje sujungtos centrine dalimi 11 . Kraštinès sraigto 30 dalys laisvai pereina per detalę 12, o per centrinès sraigto 30 dalies skylę su atsarga pralenda centrinis strypas 17. Objekto padèkle priešais atraminius stovus 39 yra skylès $a$, reikalingos padèklui tvirtinti prie stovu 39 transportavimo atveju. Nejudamame korpuse 38 ir paslankiame korpuse 14 numatytos horizontalios skylès, i kurias gali būti idèti hidrauliniai slopintuvai, turintys griovelių, užpildytų silikoninių skysčiu (1.27 pav.).

Hidraulinių slopintuvų ašys 37 su galimybe laisvai prasisukti savo skylėse galuose užsandarintos tarpikliais 36 ir užfiksuotos poveržlèmis 35. Ant slopintuvų ašių galų veržlèmis 34 standžiai užfiksuoti horizontalūs slopinimo bloko strypai 33. Iš viso šių strypu yra 8. Iš kitos pusès strypai 33 standžiai sujungti su ašimis 40.

Virpesių izoliacinè kvazinulinio standžio sistema veikia taip. Sukant sliekrati 23 îvore 25 persistumia ịvorès 24 sriegine kolonèle ir suspaudžia atraminę spyruoklę 26, kuri kartu su objekto padèklo 1 apkrova suspaudžiama i optimalaus slopinimo padèti. Sistema sureguliuojama pagal konkrečią apkrovą, lemiamą objekto padekklo masès, numatytą tam tikram apkrovų diapazonui, kurių kiekvienam turi būti apskaičiuota savo spyruoklių 26 ir 29 pora. Paveikus apkrova padèklą 1, atraminè slopinimo bloko spyruoklè 26 susispaudžia kai kuriuo dydžiu, todèl išvedimui ị optimalų aukštị būtina perstumti spyruoklę 26. Sukant sliekrati 23 dèl slieko 22 persislenka srieginè atraminè įvore 25 ir besiremiantis i spyruoklę 26 slopinimo blokas persislenka vertikaliai ir patenka i padèti, kurioje strypai 33 artimi horizontaliai padéčiai. Paskui reguliuojamas spyruoklès 29 itempimas, kuris per ịveržimo sraigtą 30 tampriai pritraukia paslankų korpusą 14 prie nejudamo korpuso 38. Prie tam tikro spyruoklès 29 ịtempimo dydžio atsiranda sąlygos, kurioms esant atsiranda sistemos kvazinulinio standžio būsena, kuriai esant slopinimo blokas pradeda ,plaukioti“" nekuriame aukščio diapazone. Horizontalus virpesių slopinimas vyksta naudojant keturis standžius strypus 9, kurie per plokštę 27, strypą 7, plokštę 3 ir pokrypių virpesių izoliatorių 2 ir pokrypių slopintuvą 5 palaiko objekto padéklą 1 . Jie padès išdèstyti objektą ant padèklo 1 strypu 9 išsidèstymo keturkampyje tiksliai centruojant objekto masę strypo ašies atžvilgiu, išliekant sistemos darbingumui. 


\subsection{Pirmojo skyriaus išvados ir disertacijos uždavinių formulavimas}

Atlikus mokslinės literatūros analizę galima daryti šias išvadas:

1. Tobulëjant šiuolaikinei virpesių izoliavimo ir matavimų technikai, žemujų dažnių virpesių izoliacijai plačiausiai naudojamos aktyviosios ir pasyviosios virpesių izoliavimo sistemos, gebančios izoliuoti pagrindu perduodamus $0,1-100 \mathrm{~Hz}$ dažnio virpesius.

2. Mokslinèse publikacijose daug dèmesio skiriama horizontaliems ir vertikaliems virpesių izoliavimo metodams ir sistemoms, jų modeliavimui, analizei ir naujos kartos sistemų kūrimui bei taikymui, tačiau pasyviosioms mechaninès koncepcijos žemojo dažnio virpesių izoliavimo sistemų tyrimams buvo skirta mažai dèmesio.

3. Pusiau aktyvios virpesių izoliavimo sistemos dažniausiai taikomos transporto priemonių ir pastatų izoliacijai ir mažai tinka metrologinei, kosminei ir mokslinei irangai izoliuoti.

4. Metrologiniai, kosminès technikos ir mokslinio tyrimo įrenginiai yra sudètingi, brangūs, didelių ir mažų matmenų. Dèl to reikia mobiliujų virpesių izoliavimo sistemų, leidžiančių dirbti aukštoje ir žemoje temperatūroje, smarkių virpesių ir radiacineje aplinkoje, vakuume.

5. Vystantis mokslui ir techninèms galimybèms tobulèjo virpesių izoliavimo sistemos, tačiau naujos kartos metrologiniai ir tyrimo įrenginiai reikalauja aukštesnio lygio virpesių izoliavimo sistemų. Todèl kilo uždavinys - kaip būtų galima sukurti mobilius mechaninès koncepcijos įrenginius, supaprastinti konstrukciją ir izoliavimo procesą, taikant kvazinulinio standžio būdus bei metodus.

6. Kitų autorių publikacijose išanalizuoti ịvairūs virpesių izoliavimo metodai, tačiau galutinis virpesių izoliavimo rezultatas yra tas pats, tik skiriasi naudojamos priemonès, aktyvių sistemu aprašymo algoritmai, keitikliai, vykdikliai, valdikliai ir kompiuterinè technika, slopintuvų tipai, o pasyviosioms sistemoms naudojamos medžiagos, technologijos ir keliami mobilumo ir žemojo dažnio virpesių izoliavimo reikalavimai, tačiau mažai paskelbta tyrimų tų problemų sprendimų paieškai, ypač kvazinulinio ir neigiamo standžio sistemoms.

Ivertinant mokslinèje literatūroje išnagrinètus klausimus tikslinga, žinant darbo tikslą, išspręsti šiuos uždavinius:

- Išanalizuoti ir pagristi mechaninių pasyviujų žemojo dažnio virpesių izoliavimo sistemų dinamini efektyvumą. 
- Pasiūlyti žemojo $(0,7-50 \mathrm{~Hz})$ dažnio virpesių izoliavimo metodą ir sistema, pagrisstą kvazinulinio standžio principu.

- Atlikti sukurtų sistemų dinaminių charakteristikų tyrimus.

- Atlikti virpesių matavimo neapibrèžties ir gautų rezultatų patiki - mumo įvertinima. 


\section{2}

\section{Žemojo dažnio virpesiụ izoliavimo sistemu dinaminiai tyrimai}

Skyriuje nagrinejami žemojo dažnio virpesių izoliavimo sistemų dinaminiai tyrimai, kaip antai platformos dinaminis pagrindimas, optiniai stalai, kai žadinamas stalviršis ir grindys, bei kvazinulinio standžio sistemos ir sudètinès sistemos, sudarytos iš optinio stalo ir kvazinulinio (neigiamo) standžio virpesių izoliavimo sistemos, kai pagrindą veikia harmoninis, impulsinis ar atsitiktinis žadinimas. Remiantis tyrimu sukurta ir užpatentuota mechaninès koncepcijos žemojo dažnio virpesių izoliavimo sistema (Berba 2012). Tyrimo originalumą nusako naujas kvazinulinio standžio virpesiu izoliavimo metodas, pagrịstas mechanine koncepcija ir masės išlyginimu. Šio skyriaus medžiaga paskelbta autoriaus publikacijose (Jurevičius et al. 2011; Berba 2012)

\subsection{Virpančios platformos (pagrindo) dinaminis pagrindimas}

Tiriant optinių stalų su pneumatiniais virpesių izoliatoriais, gaminamų imonejje UAB „Standa“, bei kvazinulinio (neigiamo) standžio virpesių izoliavimo siste- 
mas, būtina sukurti tinkamą platformos (pagrindo) virpesių žadinimo sistemą, turinčią harmonini, impulsinį ir atsitiktinį žadinimą.

Tarkime, reikia ištirti optinio stalo ar kvazinulinio standžio virpesių izoliavimo sistemos dinamines charakteristikas, kai ją veikia pagrindo, stovinčio ant tamprių virpesių izoliavimo atramų vibratoriaus sukelti žemujų dažnių virpesiai (maždaug iki $80 \mathrm{~Hz}$ ). Apytiksliai laikome pagrindą absoliučiai standžiu kūnu.

Išrenkame apibendrintąsias Lagranžo koordinates, nustatančias pagrindo padètị virpesių metu (Augustaitis 2000; Ivanauskas 2005). Tuo tikslu pradžioje sudarome koordinačiu sistemą $O_{1}, X_{1}, Y_{1}, Z_{1}$, kietai sujungtą su pagrindu ir kartu judančia su ja virpesių metu. Šios sistemos pradžios tašką $O_{1}$ parenkame sutampančiu su pagrindo standumo centru, kuris yra keturių vienodų tampriujjų atramų tvirtinimo prie pagrindo dugno plokštumoje (2.1 pav.). Visos keturios atramų tvirtinimo vietos $A_{1}, A_{2}, A_{3}, A_{4}$ yra vienodai nutolusios nuo taško $O_{1}$ ir simetriškai išsidèsčiusios jo atžvilgiu (jų padètys apibrěžiamos atstumais $l_{1}$ ir $l_{2}$ ). Paskui sudarome kita, nejudančią koordinačių sistemą $O, X, Y, Z$, kuri pagrindo ramybès būsenoje, kai ją veikia tik svorio jèga, sutampa su sistema $O_{1}, X_{1}, Y_{1}, Z_{1}$ (tokioje padetyje sistemos $O_{1}, X_{1}, Y_{1}, Z_{1}$ ir $O, X, Y, Z$ parodytos 2.1 pav.). Tarkime, kad pagrindui virpant laiko momentu $t$ sistemos $O_{1}, X_{1}, Y_{1}, Z_{1}$ pradinis taškas $O_{1}$ nesutampa su tašku $O$ ir jo padètis nejudančioje koordinačių sistemoje $O, X, Y, Z$ apibréžiama koordinatemis $x, y, z$. Be to, laikome, kad pagrindas pasisuka mažiais kampais $\varphi_{x}, \varphi_{y}, \varphi_{z}$ apie koordinačiu ašis $X_{1}, Y_{1}, Z_{1} .310$

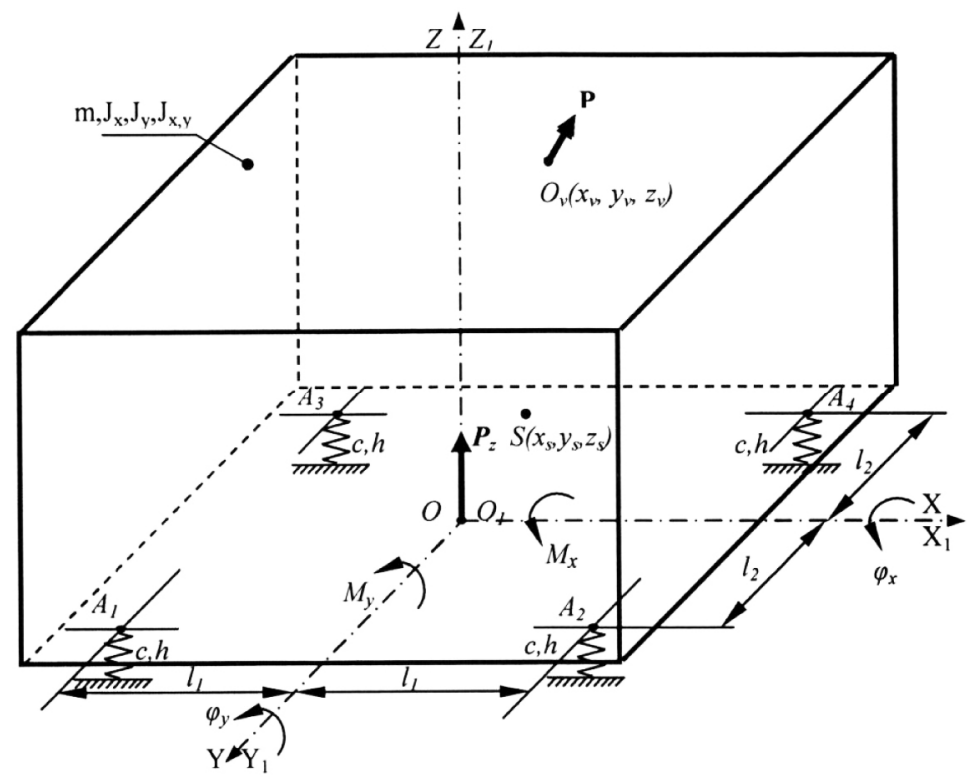

2.1 pav. Virpančios platformos (pagrindo) dinaminis modelis

Fig. 2.1. Dynamic model of a vibrating platform (base) 
Tokiu atveju pagrindo padètis virpesių metu būtų apibrèžiama šešiomis apibendrintosiomis Lagranžo koordinatėmis $x, y, z, \varphi_{x}, \varphi_{y}, \varphi_{z}$.

Tai bendras pagrindo, kai ji galima laikyti kietuoju kūnu, dinaminio modelio atvejis. Pagrindo atramos deformuojasi visų ašių atžvilgiu, bet šiuo atveju jų deformaciją nagrinèsime tiktai vertikaliaja kryptimi (jų vienodi standumo ir pasipriešinimo koeficientai $c$ ir $h$, kuriuos ir reikia parinkti).

Tada maži platformos poslinkiai virpesių metu bus apibrěžti trimis apibendrintosiomis koordinatemis: $z, \varphi_{x}, \varphi_{y}$ (slenkamujų virpesių pagal koordinates $x$ ir $y$ bei sukamujų virpesių $\varphi_{z}$ nepaisoma). Priimta (2.1 pav.), kad vibratorius sukuria harmonini žadinimą $P_{o} \sin \omega t$. Platformos masė yra $m$ (taraima, kad vibratoriaus masès itaka masei $m$ nevertinama), masių centras (svorio centras) yra taške $S$, kurio koordinatės judančioje koordinačių sistemoje pažymètos $x_{s}, y_{s}, z_{s}$. Kadangi vertinami pagrindo posūkiai $\varphi_{x}$ ir $\varphi_{y}$, reikia tureti ir jo inercijos momentus $J_{x}$ ir $J_{y}$ apie ašis $X_{1}, Y_{1}$ bei mišrų inercijos momentą $J_{x, y}$ šių ašių atžvilgiu. Platformą laikome kietuoju kūnu, todèl jos masių centro $S$ padètị ir inercijos momentus laikome pastoviais, masę $m$ taip pat laikome pastovia, t. y.

$$
\begin{gathered}
x_{s}=x_{s, 0} ; y_{s}=y_{s, 0}, \\
z_{s}=z_{s, 0} ; m=\text { const }, \\
J_{x}=J_{x, 0} ; J_{y}=J_{y, 0}, \\
J_{z}=J_{z, 0} ; J_{x, y}=J_{(x, y) 0} .
\end{gathered}
$$

Visus šiuos dydžius laikome žinomais.

Tolesnių išvedimų patogumui vibratoriaus žadinimo jègą $\boldsymbol{P}$ perkeliame $\mathrm{i}$ koordinačiu sistemos $O_{1}, X_{1}, Y_{1}, Z_{1}$ pradžią $O_{1}$, pridedami dar perkeliant atsirandančius sukimo jègų momentus $M_{x}$ ir $M_{y}$. Kadangi platformos poslinkiai pagal apibendrintąsias koordinates $x, y$ ir $\varphi_{z}$ nevertinami, perkèlus jègą $\boldsymbol{P}$ nereikia vertinti jos projekcijų i koordinačių ašis $X_{1}, Y_{1}$ bei sukamujų jègų momento apie aši $Z_{1}$. Lieka redukuotos jègos projekcija $P_{z}$, veikianti ašies $Z_{1}$ kryptimi, ir redukuoti jègų momentai (2.1 pav.):

$$
\begin{gathered}
P_{z}=P_{0} \sin \omega t \\
M_{x}=-P_{0} y_{v} \sin \omega t ; \\
M_{y}=P_{0} x_{v} \sin \omega t-P_{0} z_{v} \cos \omega t=M_{y_{0}} \sin (\omega t+\alpha) ; \\
M_{y_{0}}=P_{0} \sqrt{x_{v}^{2}+z_{v}^{2} ; \alpha=-\operatorname{arctg}\left(z_{v} / x_{v}\right)}
\end{gathered}
$$


Turedami pagal čia pateiktus duomenis sudarytą platformos dinamini modeli, pereiname prie jos virpesių lygčių sudarymo. Tai tipinè procedūra. Taikome antrojo tipo Lagranžo lygtis, kurios čia nagrinejjamu atveju bus tokios (Augustaitis 2000):

$$
\frac{d}{d t}\left(\frac{\partial T}{\partial \dot{x}_{i}}\right)-\frac{\partial T}{\partial x_{i}}+\frac{\partial \Phi}{\partial \dot{x}_{i}}+\frac{\partial \Pi}{\partial x_{i}}=F_{i} \quad(i=1,2,3),
$$

čia $T, \Pi$ - kūno kinetinè ir potencinè energijos; $\Phi$ - disipatyvinè funkcija; $x_{i}-$ $i$-toji apibendrintoji koordinate $\left(x_{1}=z, x_{2}=\varphi_{x}, x_{3}=\varphi_{y}\right), F_{i}$ - apibendrintoji jèga, veikianti pagal $i$-tają koordinatę $F_{1}=P_{z}, F_{2}=M_{x}, F_{3}=M_{y}$ ).

Norint gauti konkretų lygčių pavidala, reikia turèti dydžių $T, \Pi, \Phi, F_{i}$ analizines išraiškas.

Kinetinès energijos $T$ išraišką užrašome taip (Кожешник 1961):

$$
\begin{aligned}
& T=\frac{1}{2}\left\{m \dot{z}^{2}+J_{x} \dot{\varphi}_{x}^{2}+J_{y} \dot{\varphi}_{y}^{2}-2 J_{x, y} \dot{\varphi}_{x} \dot{\varphi}_{y}+2 m \dot{z}\left(x_{s} \dot{\varphi}_{y}-y_{s} \dot{\varphi}_{x}\right)\right\}=\frac{1}{2}\left\{m \dot{z}^{2}+\right. \\
& +\left[J_{x, 0}+J_{x, k}(t)\right] \dot{\varphi}_{x}^{2}+\left[J_{y, 0}+J_{y, k}(t)\right] \dot{\varphi}_{y}{ }^{2}-2\left[J_{(x, y) 0}+J_{(x, y) k}(t)\right] \dot{\varphi}_{x} \dot{\varphi}_{y}+ \\
& \left.+2 m \dot{z}\left[\left(x_{s, 0}+x_{s, k}(t)\right) \dot{\varphi}_{y}-\left(y_{s, 0}+y_{s, k}(t)\right) \dot{\varphi}_{x}\right]\right\}
\end{aligned}
$$

Potencinę energiją pradžioje galime parašyti tokiu pavidalu:

$$
\Pi=\frac{1}{2} c\left(\Delta_{1}^{2}+\Delta_{2}^{2}+\Delta_{3}^{2}+\Delta_{4}^{2}\right),
$$

čia $c$ - pastovus atramos vertikalaus tampriojo poslinkio standumo koeficientas (vienodas visoms atramoms); $\Delta_{j}-j$-tosios atramos tvirtinimo prie platformos vietos $A_{j}$ tamprusis poslinkis vertikaliaja kryptimi $(j=1,2,3,4)$. Išreiškiame poslinkius $\Delta_{j}$ apibendrintosiomis koordinatemis $z, \varphi_{x}, \varphi_{y}(2.1$ pav.):

$$
\begin{aligned}
& \Delta_{1} \cong z-l_{1} \varphi_{y}-l_{2} \varphi_{x} ; \quad \Delta_{2} \cong z+l_{1} \varphi_{y}-l_{2} \varphi_{x} ; \\
& \Delta_{3} \cong z-l_{1} \varphi_{y}+l_{2} \varphi_{x} ; \quad \Delta_{4} \cong z+l_{1} \varphi_{y}+l_{2} \varphi_{x} .
\end{aligned}
$$

Irašę šias $\Delta_{j}$ reikšmes i (2.5), gauname galutinę potencinès energijos išraiška:

$$
\begin{aligned}
& \Pi=\frac{1}{2} c\left[\left(z-l_{1} \varphi_{y}-l_{2} \varphi_{x}\right)^{2}+\left(z+l_{1} \varphi_{y}-l_{2} \varphi_{x}\right)^{2}+\right. \\
& \left.\left.+\left(z-l_{1} \varphi_{y}+l_{2} \varphi_{x}\right)^{2}+\left(z+l_{1} \varphi_{y}+l_{2} \varphi_{x}\right)^{2}\right)\right] .
\end{aligned}
$$


Čia konkrečiai nagrinejamajam atvejui disipatyvinès funkcijos $\Phi$ išraiška bus analogiška potencinès energijos $\Pi$ išraiškai, standumo koeficientą $c$ pakeitus pasipriešinimo koeficientu $h$, o koordinates $z, \varphi_{x}, \varphi_{y}-$ ju išvestinèmis $\dot{z}$, $\dot{\varphi}_{x}, \dot{\varphi}_{y}$ pagal laiką $t$ :

$$
\begin{aligned}
& \Phi=\frac{1}{2} h\left[\left(\dot{z}-l_{1} \dot{\varphi}_{y}-l_{2} \dot{\varphi}_{x}\right)^{2}+\left(\dot{z}+l_{1} \dot{\varphi}_{y}-l_{2} \dot{\varphi}_{x}\right)^{2}+\right. \\
& \left.\left.+\left(\dot{z}-l_{1} \dot{\varphi}_{y}+l_{2} \dot{\varphi}_{x}\right)^{2}+\left(\dot{z}+l_{1} \dot{\varphi}_{y}+l_{2} \dot{\varphi}_{x}\right)^{2}\right)\right] .
\end{aligned}
$$

Apibendrintosios jègos $F_{i}$ bus tokios (Augustaitis 2000; Ivanauskas 2005):

$$
\begin{gathered}
F_{1}=P_{z}=P_{0} \sin \omega t ; \\
F_{2}=M_{x}=-P_{0} y_{v} \sin \omega t ; \\
F_{3}=M_{y}=P_{0} x_{v} \sin \omega t-P_{0} z_{v} \cos \omega t .
\end{gathered}
$$

Randame įeinančias i (2.3) lygtis išvestines

$$
\begin{aligned}
& \frac{\partial T}{\partial \dot{z}}=m\left[\dot{z}+\left(x_{s, 0}+x_{s, k}(t)\right) \dot{\varphi}_{y}-\left(y_{s, 0}+y_{s, k}(t)\right) \dot{\varphi}_{x}\right] \\
& \frac{\partial T}{\partial \dot{\varphi}_{x}}=\left(J_{x, 0}+J_{x, k}(t)\right) \dot{\varphi}_{x}-\left(J_{(x, y) 0}+J_{(x, y) k}(t)\right) \dot{\varphi}_{y}-m \dot{z}\left(y_{s, 0}+y_{s, k}(t)\right) \\
& \frac{\partial T}{\partial \dot{\varphi}_{y}}=\left(J_{y, 0}+J_{y, k}(t)\right) \dot{\varphi}_{y}-\left(J_{(x, y) 0}+J_{(x, y) k}(t)\right) \dot{\varphi}_{x}+m \dot{z}\left(x_{s, 0}+x_{s, k}(t)\right) . \\
& \frac{d}{d t}\left(\frac{\partial T}{\partial \dot{z}}\right)=m\left(\ddot{z}+\left(x_{s, 0}+x_{s, k}(t)\right) \ddot{\varphi}_{y}+\dot{x}_{s, k}(t) \dot{\varphi}_{y}-\left(y_{s, 0}+y_{s, k}(t)\right) \ddot{\varphi}_{x}\right)- \\
& -\dot{y}_{s, k}(t) \dot{\varphi}_{x}=m\left(\ddot{z}+x_{s, 0} \ddot{\varphi}_{y}-y_{s, 0} \ddot{\varphi}_{x}\right)+h_{z} ; \\
& \frac{d}{d t}\left(\frac{\partial T}{\partial \dot{\varphi}_{x}}\right)=\left(J_{x, 0}+J_{x, k}(t)\right) \ddot{\varphi}_{x}+\dot{J}_{x, k}(t) \dot{\varphi}_{x}-\left(J_{(x, y) 0}+J_{(x, y) k}(t)\right) \ddot{\varphi}_{y}-\dot{J}_{(x, y) k}(t) \dot{\varphi}_{y}- \\
& -m\left[\left(y_{s, 0}+y_{s, k}(t)\right) \ddot{z}+\dot{y}_{s, k}(t) \dot{z}\right]=I_{x, 0} \ddot{\varphi}_{x}-I_{(x, y) 0} \ddot{\varphi}_{y}-m y_{s, 0} \ddot{z}+h_{\varphi_{x}} ; \\
& \frac{d}{d t}\left(\frac{\partial T}{\partial \dot{\varphi}_{y}}\right)=\left(J_{y, 0}+J_{y, k}(t)\right) \ddot{\varphi}_{y}+\dot{J}_{y, k}(t) \dot{\varphi}_{y}-\left(J_{(x, y) 0}+J_{(x, y) k}(t)\right) \ddot{\varphi}_{x}-\dot{J}_{(x, y) k}(t) \dot{\varphi}_{x}+ \\
& +m\left[\left(x_{s, 0}+x_{s, k}(t)\right) \ddot{z}+\dot{x}_{s, k}(t) \dot{z}\right]=I_{y, 0} \ddot{\varphi}_{y}-I_{(x, y) 0} \ddot{\varphi}_{x}+m x_{s, 0} \ddot{z}+h_{\varphi_{y}} \cdot
\end{aligned}
$$


Čia

$$
\begin{gathered}
h_{z}=m\left\{x_{s, k}(t) \ddot{\varphi}_{y}+\dot{x}_{s, k}(t) \dot{\varphi}_{y}-y_{s, k}(t) \ddot{\varphi}_{x}-\dot{y}_{s, k}(t) \dot{\varphi}_{x}\right\} \\
h_{\varphi_{x}}=J_{x, k}(t) \ddot{\varphi}_{x}+\dot{J}_{x, k}(t) \dot{\varphi}_{x}-J_{(x, y) k}(t) \ddot{\varphi}_{y}-\dot{J}_{(x, y) k}(t) \dot{\varphi}_{y}-m\left(y_{s, k}(t) \ddot{z}+\dot{y}_{s, k}(t) \dot{z}\right) \\
h_{\varphi_{y}}=J_{y, k}(t) \ddot{\varphi}_{y}+\dot{J}_{y, k}(t) \dot{\varphi}_{y}-J_{(x, y) k}(t) \ddot{\varphi}_{x}-\dot{J}_{(x, y) k}(t) \dot{\varphi}_{x}+m\left(x_{s, k}(t) \ddot{z}+\right. \\
\left.+\dot{x}_{s, k}(t) \dot{z}\right) .
\end{gathered}
$$

Aišku, kad

$$
\frac{\partial T}{\partial z}=\frac{\partial T}{\partial \varphi_{x}}=\frac{\partial T}{\partial \varphi_{y}}=0
$$

nes i kinetinę energiją apibendrintosios koordinatės $z, \varphi_{x}, \varphi_{y}$ čia nagrinejjamuoju atveju neįeina (įeina tik šių koordinačių išvestinès).

$$
\begin{gathered}
\frac{\partial \Pi}{\partial z}=c\left(z-l_{1} \varphi_{y}-l_{2} \varphi_{x}+z+l_{1} \varphi_{y}-l_{2} \varphi_{x}+z-l_{1} \varphi_{y}+l_{2} \varphi_{x}+z+l_{1} \varphi_{y}+l_{2} \varphi_{x}\right)=4 c z \\
\frac{\partial \Pi}{\partial \varphi_{x}}=c l_{2}\left(-z+l_{1} \varphi_{y}+l_{2} \varphi_{x}-z-l_{1} \varphi_{y}+l_{2} \varphi_{x}+z-l_{1} \varphi_{y}+l_{2} \varphi_{x}+z+l_{1} \varphi_{y}+l_{2} \varphi_{x}\right)=4 c l_{2}^{2} \varphi_{x} \\
\frac{\partial \Pi}{\partial \varphi_{y}}=c l_{1}\left(-z+l_{1} \varphi_{y}+l_{2} \varphi_{x}+z+l_{1} \varphi_{y}-l_{2} \varphi_{x}-z+l_{1} \varphi_{y}-l_{2} \varphi_{x}+z+l_{1} \varphi_{y}+\right. \\
\left.+l_{2} \varphi_{x}\right)=4 c l_{1}^{2} \varphi_{y} .
\end{gathered}
$$

Analogiškai

$$
\frac{\partial \Phi}{\partial \dot{z}}=4 h \dot{z} ; \frac{\partial \Phi}{\partial \dot{\varphi}_{x}}=4 h l_{2}^{2} \dot{\varphi}_{x} ; \frac{\partial \Phi}{\partial \dot{\varphi}_{y}}=4 h l_{1}^{2} \dot{\varphi}_{y} .
$$

Irašę išvestinių ir apibendrintujų jègų reikšmes i (2.11) lygtis, gauname tokias platformos virpesių diferencialines lygtis:

$$
\left\{\begin{array}{l}
m\left(\ddot{z}+x_{s, 0} \ddot{\varphi}_{y}-y_{s, 0} \ddot{\varphi}_{x}\right)+4 h \dot{z}+4 c z+h_{z}=P_{0} \sin \omega t ; \\
-m y_{s, 0} \ddot{z}+J_{x} \ddot{\varphi}_{x}-J_{(x, y) 0} \ddot{\varphi}_{y}+4 h l_{2}^{2} \dot{\varphi}_{x}+4 c l_{2}^{2} \varphi_{x}+h_{\varphi_{x}}= \\
=-P_{0} y_{v} \sin \omega t ; \\
m x_{s, 0} \ddot{z}-J_{(x, y) 0} \ddot{\varphi}_{x}+J_{y, 0} \ddot{\varphi}_{y}+4 h l_{1}^{2} \dot{\varphi}_{y}+ \\
+4 c l_{1}^{2} \varphi_{y}+h_{\varphi_{y}}=P_{0} x_{v} \sin \omega t-P_{0} z_{v} \cos \omega t .
\end{array}\right.
$$


Pažymime $\dot{z}=p z ; \ddot{z}=p^{2} z ; \dot{\varphi}_{x}=p \varphi_{x} ; \ddot{\varphi}_{x}=p^{2} \varphi_{x} ; \dot{\varphi}_{y}=p \varphi_{y} ; \ddot{\varphi}_{y}=p^{2} \varphi_{y}$, čia $p=d / d t$ - diferencijavimo operatorius. Kai ką pertvarkę gauname toki (2.15) lygčiu pavidalą:

$$
\left\{\begin{array}{l}
\left(m p^{2}+4 h p+4 c\right) z-m y_{s, 0} p^{2} \varphi_{x}+m x_{s, 0} p^{2} \varphi_{y}=P_{0} \sin \omega t-h_{z} \\
\left(J_{x, 0} p^{2}+4 h l_{2}^{2} p+4 k l_{2}^{2}\right) \varphi_{x}-J_{(x, y) 0} p^{2} \varphi_{y}-m_{s, 0} p^{2} z= \\
=-P_{0} y_{v} \sin \omega t-h_{\varphi_{x}} \\
\left(J_{y, 0} p^{2}+4 h l_{1}^{2} p+4 c l_{1}^{2}\right) \varphi_{y}-J_{(x, y) 0} p^{2} \varphi_{x}+m x_{s, 0} p^{2} z= \\
=P_{0} x_{v} \sin \omega t-P_{0} z_{v} \cos \omega t-h_{\varphi_{y}} .
\end{array}\right.
$$

Tokiu atveju

$$
\begin{aligned}
& h_{z}=m\left\{-\left(y_{s, k}(t) p^{2}+\dot{y}_{s, k}(t) p\right) \varphi_{x}+\left(x_{s, k}(t) p^{2}+\dot{x}_{s, k}(t) p\right) \varphi_{y}\right\}= \\
& =c_{1}(p, t) \varphi_{x}+c_{2}(p, t) \varphi_{y} ; \\
& h_{\varphi_{x}}=-m\left(y_{s, k}(t) p^{2}+\dot{y}_{s, k}(t) p\right) z+\left(J_{x, k}(t) p^{2}+\dot{J}_{x, k}(t) p\right) \varphi_{x}- \\
& -\left(J_{(x, y) k}(t) p^{2}-\dot{J}_{(x, y) k}(t) p\right) \varphi_{y}= \\
& =c_{1}(p, t) z+c_{3}(p, t) \varphi_{x}+c_{4}(p, t) \varphi_{y} ; \\
& h_{\varphi_{y}}=m\left(x_{s, k}(t) p^{2}+\dot{x}_{s, k}(t) p\right) z-\left(J_{(x, y) k}(t) p^{2}+\right. \\
& \left.+\dot{J}_{(x, y) k}(t) p\right) \varphi_{x}+\left(J_{y, k}(t) p^{2}+\dot{J}_{y, k}(t) p\right) \varphi_{y}= \\
& =c_{2}(p, t) z+c_{4}(p, t) \varphi_{x}+c_{5}(p, t) \varphi_{y} .
\end{aligned}
$$

Čia

$$
\begin{gathered}
c_{1}(p, t)=-m\left(y_{s, k}(t) p^{2}+\dot{y}_{s, k}(t) p\right) ; \\
c_{2}(p, t)=m\left(x_{s, k}(t) p^{2}+\dot{x}_{s, k}(t) p\right) ; \\
c_{3}(p, t)=J_{x, k}(t) p^{2}+\dot{J}_{x, k}(t) p ; \\
c_{4}(p, t)=-J_{(x, y) k}(t) p^{2}-\dot{J}_{(x, y) k}(t) p ; \\
c_{5}(p, t)=J_{y, k}(t) p^{2}+\dot{J}_{y, k}(t) p .
\end{gathered}
$$


Kaip jau minèta, dydžiai $x_{s, k}(t), y_{s, k}(t), I_{x, k}(t), I_{y, k}(t), \quad I_{(x, y) k}(t)$ ir jų išvestinès pagal laiką $t$ yra žinomos laiko funkcijos, jiems operatorius $p$ netaikomas; jis taikomas tik kintamujų $z, \varphi_{x}, \varphi_{y}$ išvestinèms pagal laiką $t$.

Ivedame (Gičian 2010; Augustaitis 2000) pažymėjimus (duotuoju atveju $n=3)$ :

$$
\begin{aligned}
& a_{1,1}(p)=m p^{2}+4 h p+4 c \\
& a_{1,2}(p)=a_{2,1}(p)=-m y_{s, 0} p^{2} \\
& a_{1,3}(p)=a_{3,1}(p)=m x_{s, 0} p^{2} \\
& a_{2,2}(p)=J_{x, 0} p^{2}+4 h l_{2}^{2} p+4 c l_{2}^{2} ; \\
& a_{2,3}(p)=a_{3,2}(p)=-I_{(x, y), 0} p^{2} \\
& a_{3,3}(p)=J_{y, 0} p^{2}+4 h l_{1}^{2} p+4 c l_{1}^{2} .
\end{aligned}
$$

Dabar vietoje (2.19) gauname tokią lygčių sistemą:

$$
\left\{\begin{array}{l}
a_{1,1}(p) z+a_{1,2}(p) \varphi_{x}+a_{1,3}(p) \varphi_{y}=F_{1}(t)-h_{z} \\
a_{2,1}(p) z+a_{2,2}(p) \varphi_{x}+a_{2,3}(p) \varphi_{y}=F_{2}(t)-h_{\varphi_{x}} \\
a_{3,1}(p) z+a_{3,2}(p) \varphi_{x}+a_{3,3}(p) \varphi_{y}=F_{3}(t)-h_{\varphi_{y}}
\end{array}\right.
$$

Gauname lygtis:

$$
\begin{aligned}
& z=\frac{1}{a_{1,1}(p)}\left[F_{1}(t)-a_{1,2}(p) \varphi_{x}-a_{1,3}(p) \varphi_{y}-h_{z}\right] ; \\
& \varphi_{x}=\frac{1}{a_{2,2}(p)}\left[F_{2}(t)-a_{2,1}(p) z-a_{2,3}(p) \varphi_{y}-h_{\varphi_{x}}\right] ; \\
& \varphi_{y}=\frac{1}{a_{3,3}(p)}\left[F_{3}(t)-a_{3,1}(p) z-a_{3,2}(p) \varphi_{x}-h_{\varphi_{y}}\right] .
\end{aligned}
$$

Skaičiuoti naudosime tik (2.21) lygti, nes tyrimams aktualūs vertikalieji platformos virpesiai, o maži posūkio kampai šiems tyrimams nèra aktualūs, be to, platformą laikème tik apytiksliai standžiu kūnu.

Skaičiavimo (Kildišas 2003) rezultatai pateikti 2.2 paveiksle. Gautas rezultatas rodo, kad nèra tikslo naudoti daugelio laisvès laipsnių sistemos matematini apraša, jeigu platforma žemuju dažnių juostoje yra absoliučiai standus kūnas (žr. 3 skyriu), tuomet platformą galima nagrinèti kaip vieno laisvès laipsnio sistemą. 
Rezultatas gaunamas analogiškas, t. y. sinusoide (2.33). Tolesniuose tyrimuose bus naudojamos tik vieno laisvès laipsnio sistemos izoliavimo efektyvumui nustatyti.

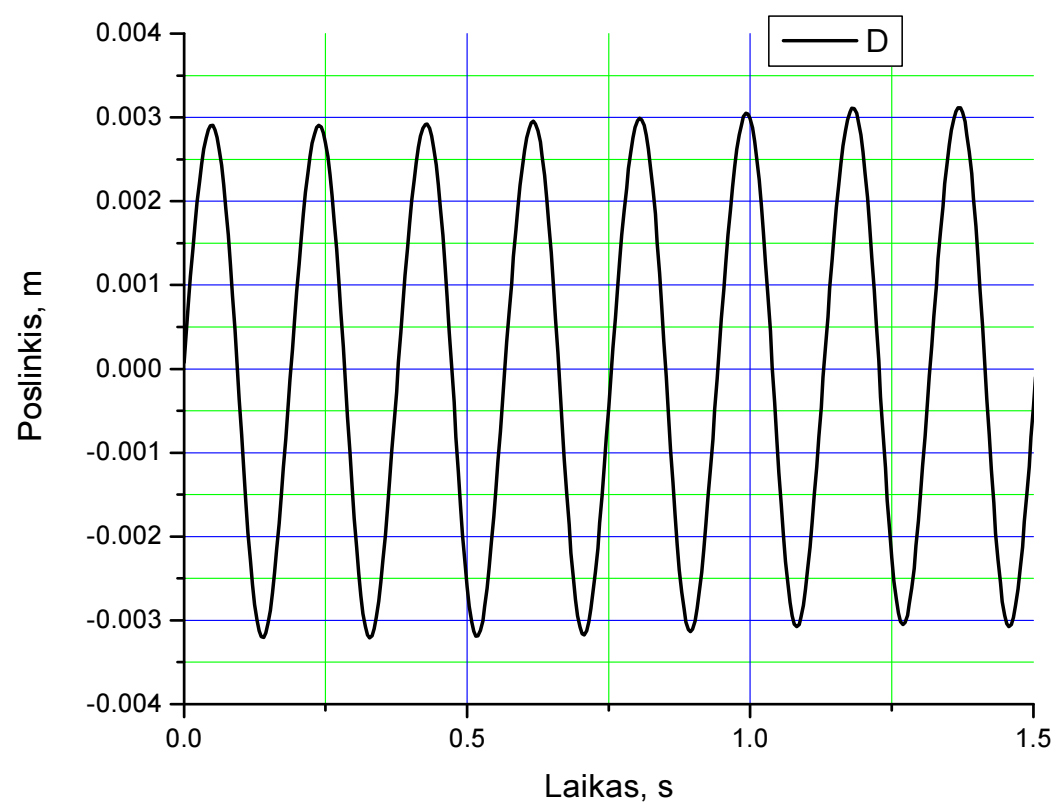

2.2 pav. Platformos harmoniniai virpesiai vertikalia kryptimi

Fig. 2.2. Harmonic vibrations of a platform in vertical direction

Analogiškai galima sumodeliuoti impulsinius ir atsitiktinius stacionarius (baltojo triukšmo) platformos virpesius. Impulsiniai virpesiai parodyti 2.3 pav., a, o tipiniai baltojo triukšmo virpesiai, kuriuos sukelia platforma (2.1 pav.) parodyti 2.3 pav. b. Jo spektras yra pastovus dydis ir lygus $S_{0}$. 


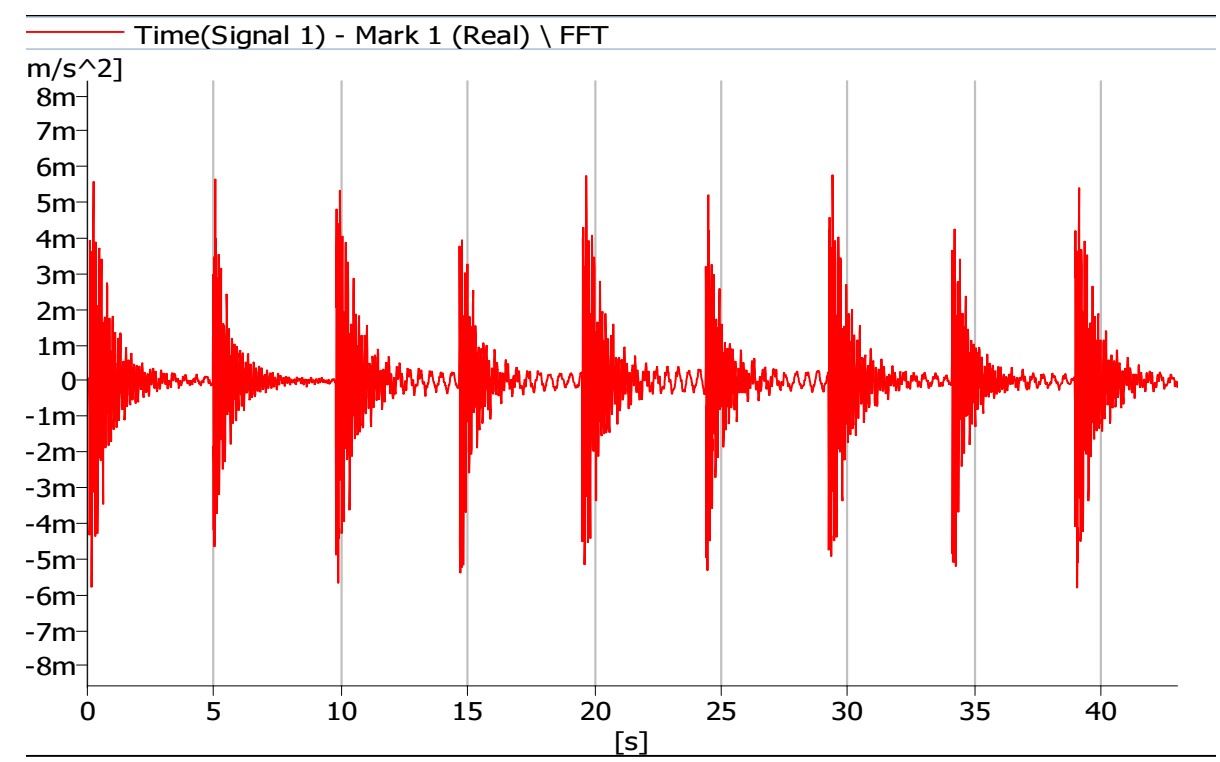

a

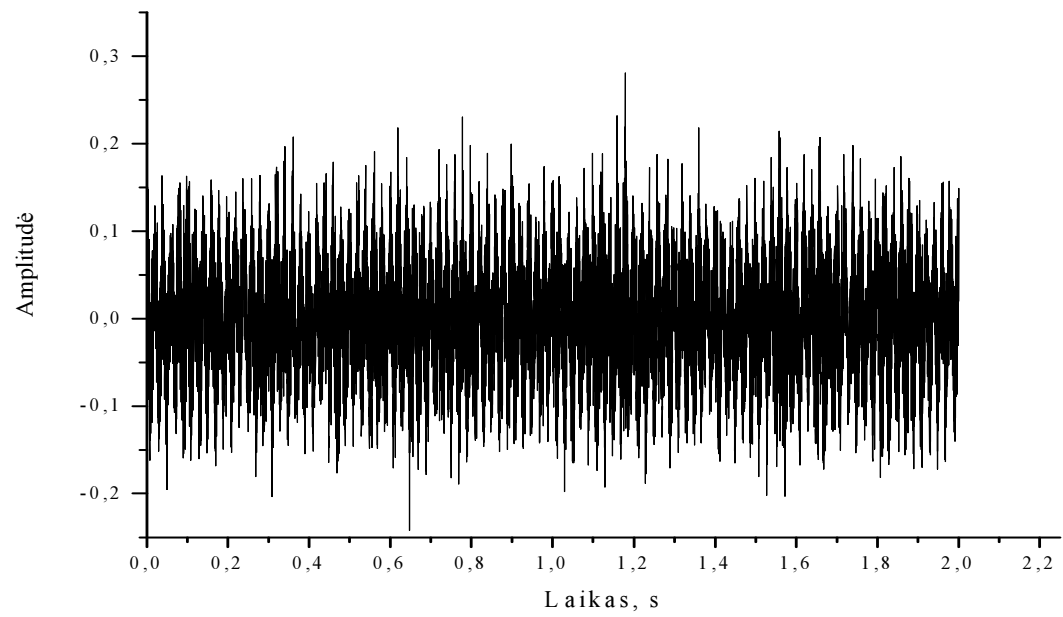

b

2.3 pav. Platformos žadinami impulsiniai (a) ir atsitiktiniai (b) stacionarūs virpesiai (baltasis triukšmas)

Fig. 2.3. Exited vibrations of a platform - impulse (a), random (b), stacionarry (white noise) 


\subsection{Optinio stalo ant virpančios platformos dinaminiai tyrimai}

Optini stalą (2.2 pav., a) su pneumatiniais virpesių izoliatoriais, padètą ant virpančios platformos, galima nagrinèti kaip šešių laisvès laipsnių sistemą arba kaip vieno laisvès laipsnio sistemą (2.2 pav., b, c), kai izoliatorių parametrai identiški ir stalviršis žemuosiuose dažniuose (iki $80 \mathrm{~Hz}$ ) yra standusis kūnas.

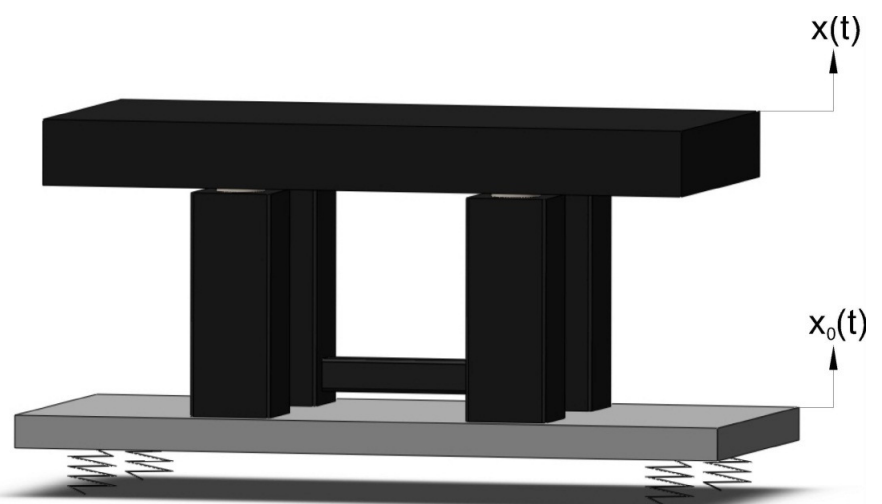

a

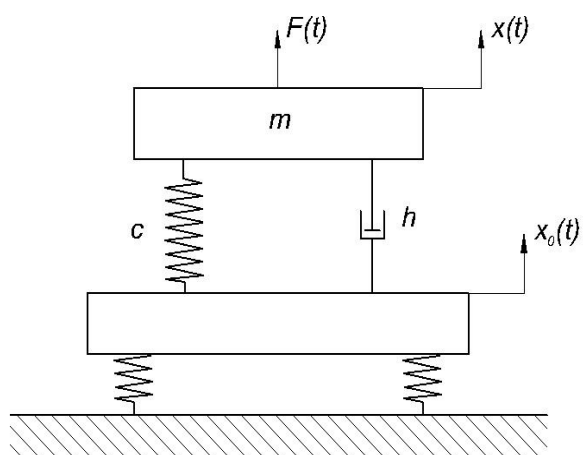

b

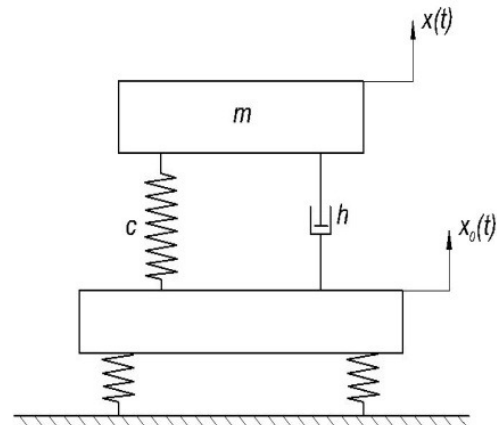

$\mathrm{c}$

2.4 pav. Optinio stalo (a) ant virpančios platformos dinaminiai modeliai: $\mathrm{b}$ - kai žadinama masè $m$ jèga $F(t)$; c - kai žadinama platforma

Fig. 2.4. Dynamic models: of an optical table on vibrating platform $(a) ; b-$ at excitation of mass $m$ by force $F(t)$; - at excitation of platform

Norėdami nustatyti stalo dinaminị slankị ir sistemos rezonansinius dažnius, masę $m$ veikiame jèga $F(t)$. Tokiu būdu šešiu laisvès laipsnių sistemos (2.4 pav., a) diferencialinè lygtis, kai žadinimo jèga veikia stalviršĭ atrodys taip: 


$$
M \ddot{x}(t)+H \dot{x}(t)+C x(t)=F(t),
$$

čia $M, H$ ir $C$ - masès, slopinimo koeficientu ir standumo koeficientų $6 \times 6 \mathrm{dy}-$ džio matricos; $F(t)$ - apibendrintų išorinių jègų stulpelinè matrica. Tuo atveju, kai platforma virpa dydžiu $X_{0}(t)=X_{0}$ expiwt, diferencialinè lygtis (2.24) turi toki pavidalą

$$
M \ddot{x}(t)+H \dot{x}(t)+C x(t)=(C+i H w) X_{0} \operatorname{expi\omega t.}
$$

Norint nustatyti stalo dinamini slankị ir sistemos rezonansinius dažnius, esant identiškiems virpesių izoliatoriams (remiantis eksperimentiniais tyrimais, pateiktais 3 skyriuje), patogu naudotis vieno laisvès laipsnio sistema (2.4 pav., b). Tokiu būdu šios sistemos (2.4 pav., b) diferencialinè lygtis (2.24) atrodys taip:

$$
m \ddot{x}(t)+h \dot{x}(t)+c x(t)=F(t) .
$$

Jeigu žadinimo jèga turi harmoninę išraišką $F(t)+F_{0}(t) \cos \omega t, x_{0}(t)=0$, tai sistemos rezonansiniai dažniai gauti iš (2.26) lygties dalinio sprendinio:

$$
X_{a^{\prime}}=F_{0} \cos (\omega t-\varphi) / \sqrt{\left(c-m \omega^{2}\right)^{2}+\omega^{2} h^{2}}
$$

čia $\varphi=\operatorname{arctg}\left[h \omega /\left(c-m \omega^{2}\right)\right]$.

Pagal poslinki, greiti ir pagreiti atitinkamai sutvarkyti atrodys taip:

$$
\begin{gathered}
\omega_{r}=\sqrt{\omega_{0}^{2}\left(1-2 \xi^{2}\right)}=\omega_{0} \sqrt{\left(1-2 \xi^{2}\right)}, \\
\omega_{r, v}=\omega_{0}, \\
\omega_{r, a}=\sqrt{w_{0}^{2}\left(\frac{1}{1-2 \xi^{2}}\right)}=\omega_{0} \sqrt{\left(\frac{1}{1-2 \xi^{2}}\right)} .
\end{gathered}
$$

Kai $\xi$ kinta nuo 0 iki 0,7 , skirtumas tarp šių rezonansinių dažnių nèra didelis. Tiriamų optinių stalų apskaičiuoti rezonansiniai dažniai svyruoja nuo 3 iki $4 \mathrm{~Hz}$. Eksperimentiškai gauti rezonansiniai dažniai pateikti 3 skyriuje.

Optinio stalo savybès apibūdinamos ne tik rezonansiniais dažniais, bet ir stalo matmenų, pastatymo ant atramų vietos, viršutinès ir apatinès stalviršio plokščių bei šoninių sienų savybių, šerdies konstrukcijos ir medžiagos, apkrovos dydžio, jos paskirstymo ir kt. Maksimalus ilinkis, veikiant statinei apkrovai, laikomas stalviršio standžio matu.

Stalo ir platformos dinamines charakteristikas geriausiai ivertina dinaminis slankis - atvirkščias dinaminiam standžiui dydis. Slankio kreivès rodo poslinkio amplitudę taške, kuri veikia vienetinè jèga kaip dažnio funkcija. 
Optinio stalo ir platformos slankio kreivès rodo stalviršio dinaminę reakciją laisvoje erdveje ir paviršiaus plokštumos iškarpymus, veikiant stalą ir platformą virpesiams. Ji nusako dažnio ruožă, kuriame optinis stalas ir platforma elgiasi kaip visiškai standus kūnas ir suteikia informaciją apie du pagrindinius parametrus, turinčius įtakos dinaminėms charakteristikoms - minimalų rezonansinį dažnị ir maksimalu rezonansini stiprinimą, kurie gali būti naudojami skaičiuojant tikraji santykini judesį tarp dviejų taškų, esančių ant struktūros paviršiaus.

Slankis išreiškiamas formule:

$$
S=\left|\frac{x}{F}\right|,
$$

čia $|x|$ - virpesių poslinkio amplitudè; $|F|$ - jègos amplitudè. Slankio matas yra $\mathrm{mm} / \mathrm{N}$.

Idealiai standaus kūno matematinio modelio išraiška tokia:

$$
M \ddot{x}=F .
$$

Kai standujj masės $M$ kūną veikia išorinè harmoninė jèga, šios lygties sprendinys yra:

$$
x=x_{0} \sin (\omega t)
$$

Čia $x_{0}=-\frac{F_{0}}{M \omega^{2}}$.

Tai reiškia, kad kūnas juda harmoniniu dèsniu ir judesio amplitude yra atvirkščiai proporcinga kampinio dažnio kvadratui. Šiame pavyzdyje slankis $s$ yra:

$$
S=\left|\frac{x_{0}}{F_{0}}\right|=\frac{1}{M \omega^{2}},
$$

t. y. idealiai standaus kūno slankis proporcingas $1 / \omega^{2}$ ir logaritminiame mastelyje vaizduojamas tiesia linija.

Nestandiems kūnams slankio kreivès rodo rezonansinius struktūros dažnius ir maksimalu stiprinima, esant rezonansui. Slankis - patikima konkrečios mechaninès sistemos charakteristika.

Dinaminis ìlinkio koeficientas DİK (Dynamic Deflection - DDC) įvertina santykinę dinaminę stalviršio charakteristiką. Šis koeficientas gali būti nustatytas iš slankio kreivès, atlikus skaičiavimus pagal formulę:

$$
\operatorname{DI} \mathrm{K}(D D C)=\sqrt{\frac{Q}{f_{0}^{3}}},
$$


čia $f_{0}$ - rezonansinis dažnis; $Q=A / B$ - stiprinimo faktorius rezonansiniame dažnyje.

Koeficientai $A$ ir $B$ randami iš eksperimentinès dinaminio slankio kreivès. Geras stalviršis apibūdinamas žemu dinaminiu įlinkio koeficientu.

Maksimalus santykinis stalviršio judesys (Maximum Relative Table Motion - MRTM) yra santykinis judejjimas tarp dviejų stalviršio taškų. Kuo didesnis ivvairių taškų judesys, tuo blogesnis stalviršio stabilumas ir mažiau tikètina, kad ant stalo paviršiaus sumontuotų komponentų justiravimas bus įmanomas. Santykinis judesys priklauso ne tik dinaminių nuo stalviršio charakteristikų, bet ir nuo izoliavimo sistemos charakteristikų ir aplinkos virpesių.

Maksimalus santykinis stalviršio judesys

$$
M R T M=C T \sqrt{\left(\frac{Q}{f_{0}^{3}} \cdot(P S D)\right)},
$$

čia $T$ - izoliatoriaus perduodamumo koeficientas; $Q$ - stiprinimo faktorius, apskaičiuotas iš slankio kreivès; $P S D$ - aplinkos virpesių intensyvumo lygio spektrinis galios tankis $(S G T)$; C - konstanta, kuri nustato pagreičio vienetus ir padidina vertę dvigubai, kad būtų ívertintas blogiausias bet kurių dviejų taškų tarpusavio judesio atvejis.

$$
C=2 g \sqrt{\frac{1}{32 \pi^{3}}}=0,623 \mathrm{~m} / \mathrm{s}^{2} .
$$

Tuo atveju kai platforma virpa (2.4 pav., c) dydžiu $x_{0}(t)=x_{0} \exp (i \omega t)$, sistemos judejjimo difirencialinè lygtis (2.25) turès toki pavidalą:

$$
m \ddot{x}(t)+h \dot{x}(t)+c x(t)=(c+i h \omega) X_{0} \exp i \omega t .
$$

Jeigu platformos virpesiai turi harmoninę išraišką $X_{0} \cos w t$, iš lygties (2.38) lengvai randame (Gurecki 1981; Benaroya 2004) sistemos perduodamumo koeficientus:

absoliutus:

$$
T_{\ddot{x}}=\frac{\ddot{x}}{\ddot{x}_{0}}=\left[\frac{1+\left(2 \xi \omega / \omega_{0}\right)^{2}}{\left(1-\omega^{2} / \omega_{0}^{2}\right)^{2}+\left(2 \xi \omega / \omega_{0}\right)^{2}}\right]^{1 / 2},
$$

santykinis: 


$$
T_{x-x_{0}}=\left|\frac{x-x_{0}}{x_{0}}\right|=\frac{\left(\frac{\omega}{\omega_{0}}\right)^{2}}{\left[1-\left(\frac{\omega}{\omega_{0}}\right)^{2}\right]^{2}+4 \xi^{2}\left(\frac{\omega}{\omega_{0}}\right)^{2}} .
$$

Pagreičio ir santykinio poslinkio perduodamumas parodytas 2.5 paveiksle, a, b. Matome, kad virpesių slopinimas prasideda nuo $5 \mathrm{~Hz}$.

Jeigu optinis stalas laboratorijoje pastatytas ant grindų, reikia ịvertinti aplinkos virpesius. Aplinkos virpesių intensyvumo lygiui apibūdinti vartojama spektrinio galios tankio SGT (Power Spectral Density - PSD) sąvoka.

Spektrinis galios tankis yra bendras terminas, vartojamas neatsižvelgiant $\mathfrak{i}$ fizikinius vyksmus. Esamas fizikinis vyksmas nurodomas atitinkamais duomenimis. Pvz., terminas pagreičio amplitudès spektrinis galios tankis arba spektrinis pagreičio amplitudès tankis vartojamas vietoj termino spektrinis galios tan$k i s$, kai apibūdinamas pagreičio amplitudès spektras. Tarptautiniame standarte (ISO 2041:2009) pateiktas toks spektrinio galios tankio apibūdinimas: „Dydžio $X_{0}(t)$ spektrinis galios tankis $S(f)$ yra dydžio dalies, einančios pro siaurajuosti filtra, kurio centrinis dažnis $f$, vidutinè kvadratinè vertè, tenkanti vienetinès juostos pločiui, kai jis artejja prie nulio, o vidurkinimo trukmè - prie begalybès“".

Spektrinis galios tankis išreiškiamas taip:

$$
S(f)=\lim _{T \rightarrow \infty}^{B \rightarrow 0} \frac{1}{B T_{v}} \int_{0}^{T} X_{0}^{2}(f, t, B) d t,
$$

čia $X_{0}^{2}(f, t, B)$ - dydžio $X_{0}(t)$, perejjusio pro siaurajuosti filtrą, kurio juostos plotis $b$, o centrinis dažnis $f$, kvadratas; $T v$ - vidurkinimo trukmè.

Pritaikant Fourier transformacija, $S(f)$ reiškiamas taip:

$$
\begin{gathered}
S(f)=\lim _{T \rightarrow \infty} \frac{2}{T_{v}}\left|F\left(f, T_{v}\right)\right|^{2} ; \\
f \geq 0 ; \\
F\left(f, T_{v}\right)=\int_{0}^{T} X_{0}(t) e^{-i 2 \pi f t} d t .
\end{gathered}
$$

Esant nusistovejusiems vyksmams, spektrinis galios tankis lygus dvigubai autokoreliacijos funkcijos Fourier transformacijai ir išreiškiamas šia formule:

$$
S(f)=2 \int_{-\infty}^{\infty} k(t) e e^{-i 2 \pi f t^{-2 \pi f t}} d t=4 \int_{0}^{\infty} k(t) \cos (2 \pi f t) d t(f \geq 0) .
$$




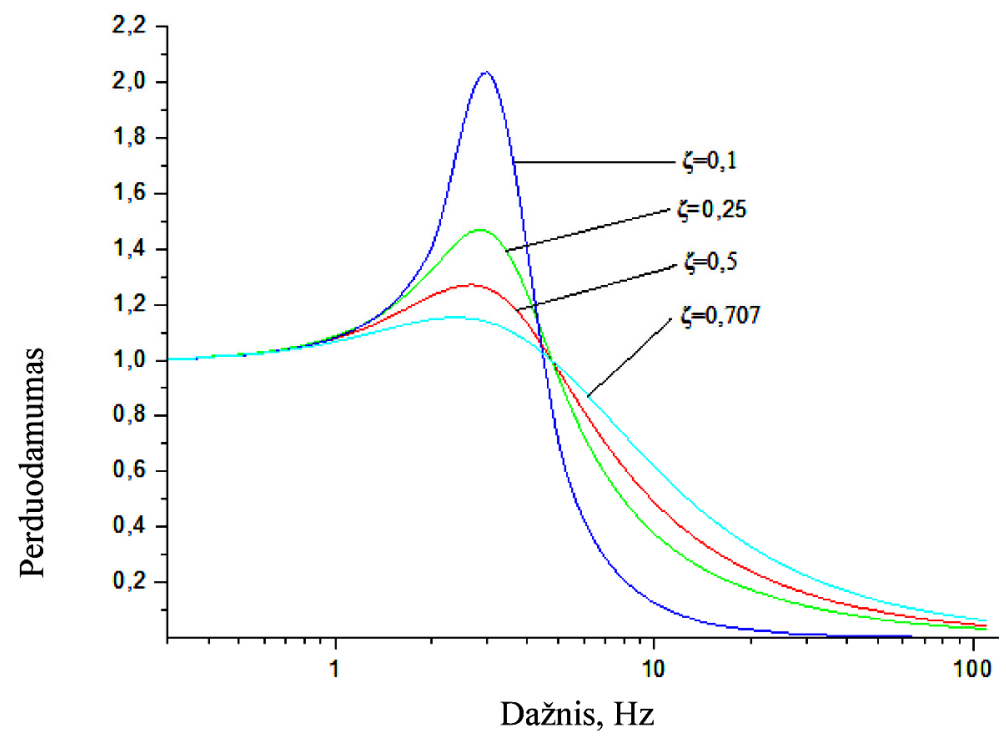

a

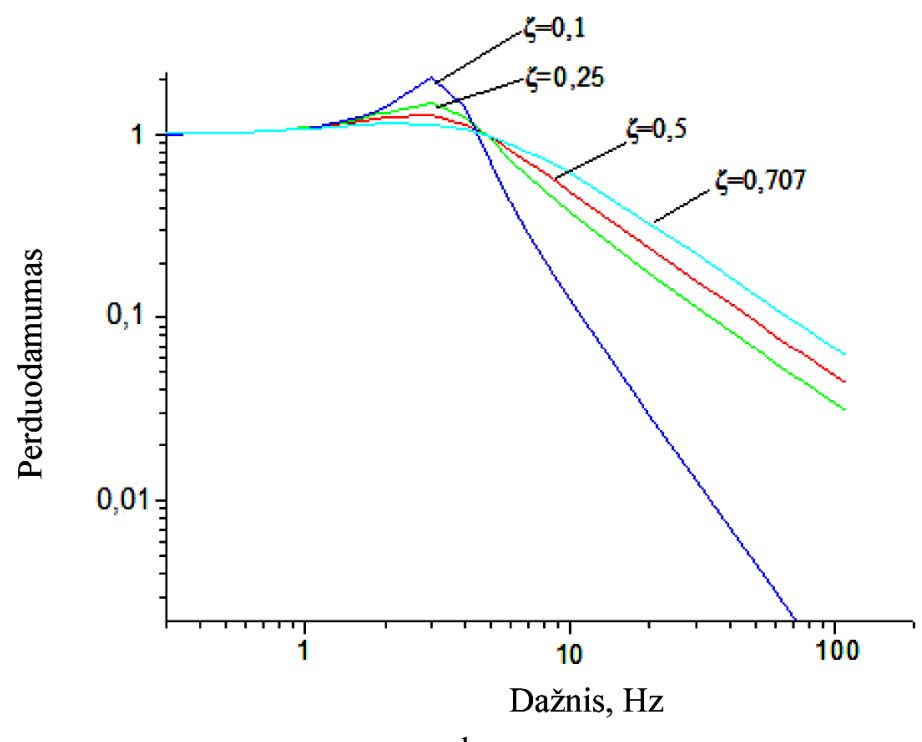

$\mathrm{b}$

2.5 pav. Optinio stalo perduodamumo kreivès: $a$ - absoliuti; $b$ - santykinè Fig. 2.5. Transmissibility curves of optical tabale: $a-$ absoliute; $b$ - relative

Spektrinis galios tankis SGT (Power Spectral Density - PSD) naudojamas aplinkos virpesių intensyvumo lygiui apibūdinti. 


\subsection{Kvazinulinio standžio virpesių izoliavimo sistemos naujumas ir jos dinaminiai tyrimai}

Sistema skirta tikslių irenginių virpesiams izoliuoti, ypač įvairiapusèms virpesių izoliacinèms pakaboms, kurių mažas standis ir stiprus sistemos rezonansinių reiškinių slopinimas.

Patentas paremtas tuo, kad iqveržtoje tamprioje sistemoje, sudarytoje horizontalių ir vertikalių tarpusavyje sąveikaujančių spyruoklių, grąžinančių i pradinę padèti, jègos priklausomybè nuo persislinkimo, sukelto išorinio poveikio, yra sinusoidiška (1.26 pav.). Pateikta mechaninè kvazinulinio standžio virpesių izoliavimo sistema sudaryta iš įveržtų vertikalių ir horizontalių spyruoklių, jų iveržtumą palaikant svertų deformacijomis, kurių pokrypiai tiek vertikalioje, tiek horizontaliojoje plokštumoje artimi $0^{\circ}$. Tai tame labai mažame perslinkimų diapazone ir užtikrina kvazinulinį sistemos (2.6 pav.) standi (Berba 2012).

Sistemos (2.6 pav.) naujumas pasireiškia tuo, kad:

1. Mechaninę kvazinulinio standžio virpesių izoliavimo sistemą sudaro viršutinio objekto padèklas, besiremiantis į tampria struktūra susietų vertikaliujų ir horizontaliujų virpesių komponentų slopintuvų visumą. Ji ịrengiama ant apatinės bazinès plokštès, kurios centre pastatomas atraminès vertikalios spyruoklès reguliavimo irenginys. Šis sureguliuotas taip, kad vienu galu spyruoklè pagal apkrovos masę per jos centre sumontuoto centrinio strypo atramini paviršių užtikrina darbingumui reikalingą vertikalų standị ir padèti. Kitu galu, tampriai sąveikaudama su horizontaliu svertu irenginiu, ji užtikrina darbingumui reikalingą kvazinulini standi, veikianti priešinga pirmajam kryptimi. Ši sistema skiriasi tuo, kad vertikaliam standžiui reguliuoti naudota sliekinè pora, kai sliekas sumontuotas standžiai ant bazinès plokštès, o sliekratis - koncentriškai ant atraminès srieginès ivorès, savo vidine skyle laisvai praleidžiančios centrinị strypa, apsaugotos nuo prasisukimo, vienu galu besiremiančios i bazinę plokštę, kitu galu - i atraminę spyruoklę. Tuo pat metu atraminis centrinio strypo paviršius yra su strypu sujungto horizontalaus slopinimo bloko viršutinès dalies apatinis paviršius, kai šis blokas sudarytas iš dviejų dalių. Apatinè dalis yra standžiai sujungta su centrinio strypo apačia, o su viršutine - keturiais standžiais strypais, vienodai nutolusiais nuo centro ir laisvai pereinančiais per bazinę plokštę, kurie yra kaip svertai dèl nedidelio horizontalaus paslankumo galimybès, kurią sudaro tam pritaikyta slopinimo bloko konstrukcija.

2. Mechaninè kvazinulinio standžio virpesių izoliavimo sistema pagal 1 punktą skiriasi tuo, kad horizontalaus slopinimo bloko viršutinė dalis yra susieta su bazine plokšte korpusais. Vienas jų yra standžiai pritvirtintas prie bazinès plokštès, o kitas, esantis pirmajam priešpriešiais, prie minètos plokštès standžiai pritvirtintas tik savo apatine dalimi. Ši yra tik plokščių spyruoklių, ją jungiančių su viršutine dalimi, tvirtinimo korpusas. Viršutinè korpuso dalis dèl to turi mažo 
slankumo galimybę. Tai savo ruožtu kelia nedidelio slopinimo bloko viršutinès dalies vertikalaus poslinkio poreiki. Tai realizuojama per artimą horizontaliems slopinimo bloko strypams jų poru galų lankstini imontavimą iš vienos pusès $\mathfrak{i}$ viršutines minètų slopinimo korpusų dalis, iš kitos - i viršutinę slopinimo bloko dali. Tarp taip sudarytų lankstų galų sumontuotas bent vienas horizontalus hidraulinis slopintuvas, o per korpusų centrus laisvai pereina bloko įveržimo sraigtas. Jis savo galus sujungiančia centrinès plokštelès skyle laisvai prasilenkia su centriniu sistemos strypu ir yra ịveržtas reguliuojamaja spyruokle.

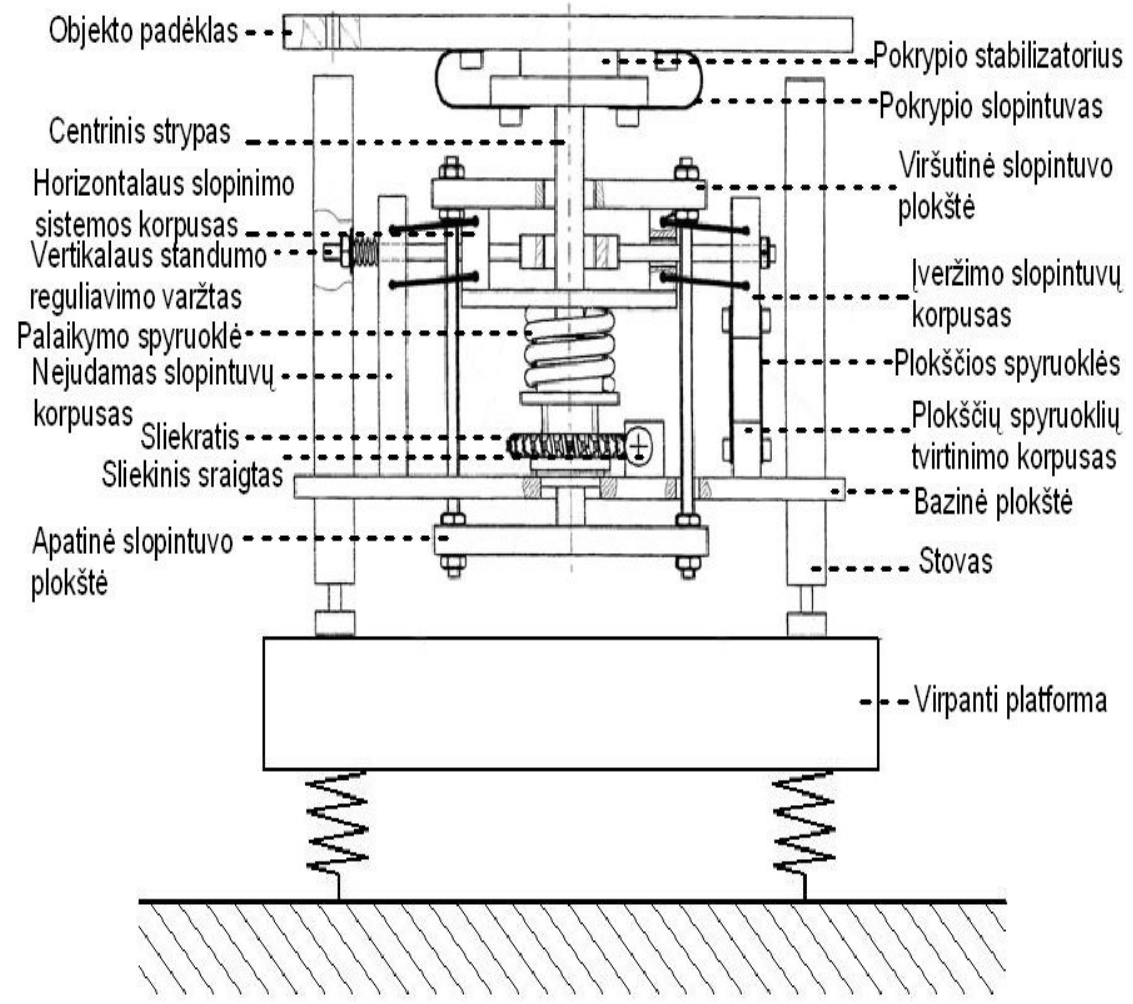

2.6 pav. Kvazinulinio standžio virpesių izoliavimo sistema ant virpančios platformos (Berba 2012)

Fig. 2.6. System of isolation of quasi-zero stiffness on a vibrating platform (Berba 2012)

3. Mechaninè kvazinulinio standžio virpesių izoliavimo sistema pagal 1 ir 2 punktus skiriasi tuo, kad turi tris ar keturias standžiai sujungtas su bazine plokšte atramas objekto padèklo svoriui atremti ir padèklo pokrypio slopinimo pakaba, tampriai susijusią su centrinio strypo viršutiniu atraminiu paviršiumi. 
4. Mechaninè kvazinulinio standžio virpesių izoliavimo sistema pagal 1 ir 2 punktus skiriasi tuo, kad hidrauliniai slopintuvai imontuoti į horizontalias skyles nejudamuose slopintuvų bloko korpusuose, susijusiuose su bazine plokšte ir turi daug griovelių, užpildytų klampiu skysčiu, o slopintuvų ašys turi laisvo prasisukimo savo skylèse galimybes. Be to, ju galai užsandarinti tarpikliais ir ant jų standžiai užfiksuoti artimi horizontaliems strypai, vienodai nutolę nuo slopinimo bloko ašies.

5. Mechaninè kvazinulinio standžio virpesių izoliavimo sistema pagal 1, 2, 3 ir 4 punktus skiriasi tuo, kad skirtingoms objekto masèms parenkamos skirtingos atraminès spyruoklès.

6. Mechaninè kvazinulinio standžio virpesių izoliavimo sistema pagal 1,2 ir 3 punktus skiriasi tuo, kad objekto padéklas per centrini strypą, apatinę slopinimo bloko plokštę ir tamprią likusią sistemos struktūrą yra pakabintas ant riboto standumo strypų.

Kvazinulinio standžio virpesių izoliavimo sistemos dinaminis modelis parodytas 2.7 pav., a, b.

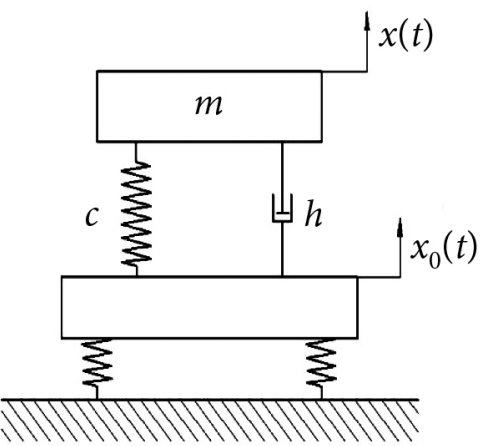

a

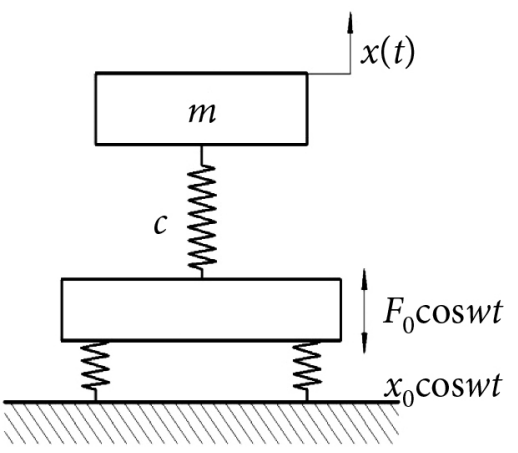

b

2.7 pav. Kvazinulinio standžio virpesių izoliavimo sistemos dinaminiai modeliai: a - su tampriai klampiu slopinimu; b - su tampriu slopinimu

Fig. 2.7. Dynamic models of a quasi-zero stiffness vibration isolation: $a$ - with elastic viscous damping; $b$ - with elastic damping

Tokios sistemos (2.7 pav., a) diferencialinè lygtis, kai platformos judèjimas harmoninis, turès toki pavidalą:

$$
m\left(\ddot{x}-\ddot{x}_{0}\right)+h\left(\dot{x}-\dot{x}_{0}\right)+c\left(x-x_{0}\right)=0 .
$$

Irašę i (2.45) lygti platformos judesio išraišką $x_{0}(t)=x_{0} \exp (i \omega t)$ gausime: 


$$
m \ddot{x}+h \dot{x}+c x=(c+i h \omega) x_{0} e^{i \omega t} .
$$

Kai platforma gauna kinematini harmonini žadinimą tokio pavidalo $x_{0} \cos w t$, tai prie nusistovejusių platformos virpesių lygties (2.45) sprendiniai yra klasikinio pobūdžio (Benaroya 2004). Tuomet esant klampiai tampriam slopinimui iš lygties (2.45) sprendinių randame absoliutaus pagreičio amplitudès perduodamumą:

$$
T_{\eta}=\frac{\sqrt{1+4 \xi^{2} \frac{\omega^{2}}{\omega_{0}^{2}}}}{\sqrt{\left(1-\frac{\omega^{2}}{\omega_{0}^{2}}\right)^{2}+4 \xi^{2} \frac{\omega^{2}}{\omega_{0}^{2}}}} .
$$

Kai sistemoje yra tik histerezinis slopinimas, tuomet perduodamumas turès toki pavidalą:

$$
T_{\eta}=\frac{\omega^{2} / \omega_{0}^{2}}{\sqrt{\left(1-\frac{\omega^{2}}{\omega_{0}^{2}}\right)^{2}+\eta^{2}}},
$$

čia $\eta$ - energijos sklaida arba energijos absorbcijos (sugerties) koeficientas.

Šiu perduodamumų grafikai parodyti 2.7 pav., a, b.

Tiriant kvazinulinio standžio virpesių izoliavimo sistema, kuri yra mechaninès koncepcijos, galima nagrinèti jos slopinimo charakteristikas kaip vidinę trinti kietajame kūne. Dinaminiai tokios sistemos modeliai parodyti 2.7 pav., $\mathrm{a}, \mathrm{b}$.

Šiame tyrime vidinès trinties hipotezėmis suprantamos tokios hipotezès, kurios sudaro galimybę spręsti tiesines diferencialines virpesių lygtis su pastoviais koeficientais elementariomis funkcijomis, jeigu tokiomis pat funkcijomis galima išreikšti žadinima, esantị dešinèje lygčių pusèje.

Šiuo metu plačiai paplitusi Foigto (Voigt 1892) hipotezè, kai vidinè trintis priklauso nuo virpesių dažnio (2.9 pav.), taip pat kai nuo jo nepriklauso (Sorokin 1976).

$$
\eta=\frac{h}{c}|\omega|
$$

Tarkime, nuosaviesiems platformos (2.7 pav., a) harmoniniams priverstiniams virpesiams vieno laisvès laipsnio sistemos diferencialinè lygtis, kai vidinè trintis nepriklauso nuo dažnio, turès tokią išraišką (Bock 1932): 


$$
m \ddot{x}+\frac{\eta}{\omega} c \dot{x}+c x=F_{0} \cos \omega t,
$$

čia $c$-sistemos standumas; $\eta$-vidinès trinties pastovus koeficientas; $m$ - masė; $F_{0}$-jègos amplitude; $\omega$-žadinimo dažnis.
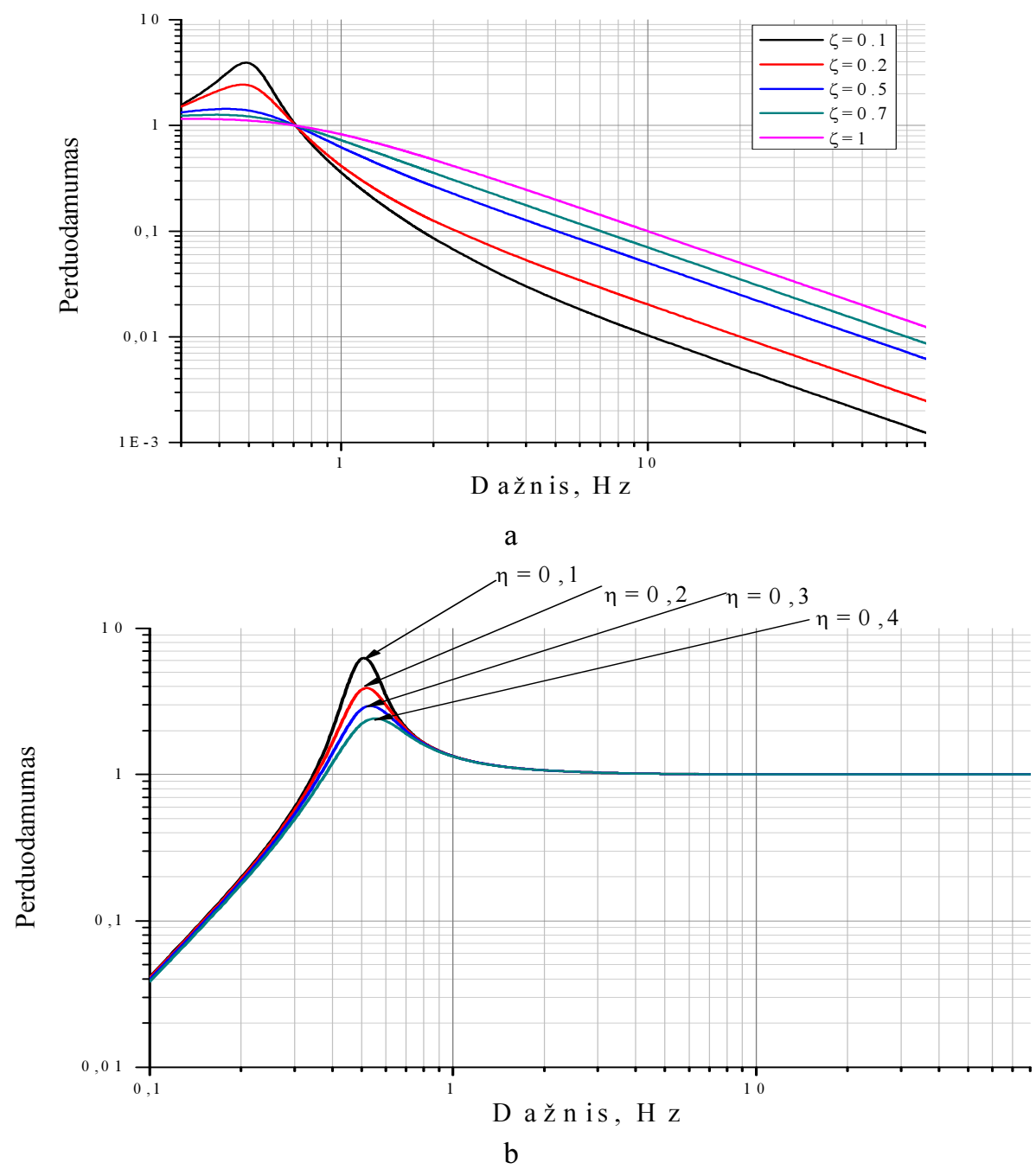

2.8 pav. Perduodamumas: a - prie klampiai tampraus slopinimo; $\mathrm{b}$ - prie histerezinio slopinimo

Fig. 2.8. Transmissibilities: $a-$ at viscous-elastic damping; $b-$ at hysteresis damping 


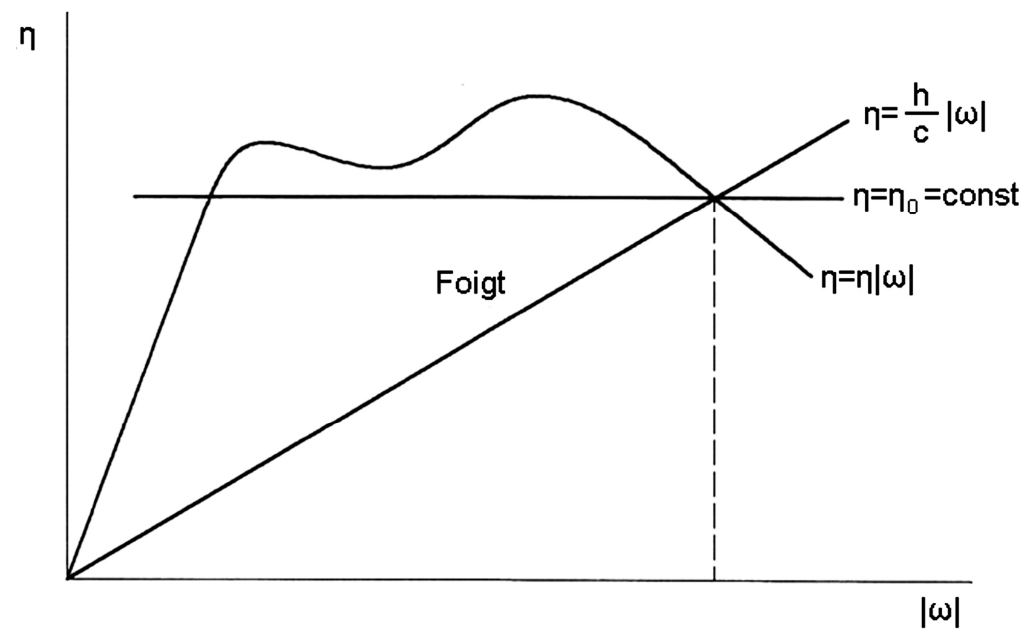

2.9 pav. Vidinès trinties priklausomybių grafikai atsižvelgiant ị virpesių dažnị (Voigt 1892; Sorokin 1976)

Fig 2.9. Graphics of internal friction dependencies, dependent on vibration frequency (Voigt 1892, Sorokin 1976)

Šios lygties sprendinys, esant nusistovèjusiems virpesiams, atrodys taip:

$$
x=\frac{x_{0}}{\sqrt{\left(1-\frac{\omega^{2}}{\omega_{0}^{2}}\right)^{2}+\eta^{2}}} \cos \left(\omega t-\varphi_{0}\right),
$$

čia $\omega_{0}=\sqrt{\frac{c}{m}} ; x_{0}=\frac{F_{0}}{c} ; \operatorname{tg} \varphi_{0}=\frac{\eta \omega_{0}^{2}}{\omega_{0}^{2}-\omega^{2}}$.

Jeigu palygintume (2.49) lygties sprendinius esant Foigto hipotezei:

$$
x=\frac{x_{0} \cos (\omega t-\varphi)}{\sqrt{\left(1-\frac{\omega^{2}}{\omega_{0}^{2}}\right)^{2}+\frac{h \omega^{2}}{c m \omega_{0}^{2}}}}
$$

čia: $\operatorname{tg} \varphi=\frac{h \omega}{m\left(\omega_{0}^{2}-\omega^{2}\right)}$.

Kai priimama Foigto hipotezè: $R=-h \dot{x}$ čia $R$ - vidinès trinties jèga.

Matome, kad lygtis (2.51) gaunama iš lygties (2.50) keičiant 


$$
h=\frac{\eta c}{m} .
$$

Iš lygties (2.52) matyti, kad pasipriešinimo koeficientas $h$ turi būti ne pastovus dydis, bet atvirkščiai proporcingas žadinimo virpesių dažniui.

Gauti rezultatai tinka tik nusistovejusiems harmoniniams virpesiams su dažniu $\omega$.

Buvo pasiūlyta (Crandall 1970) naudoti Foigto hipotezę slopinimo aprašui, laisvai priklausomam nuo virpesių dažnio, ir kitu atveju - nepriklausomam nuo dažnio. Sakykime, kad nuostolių koeficiento $\eta$ faktinè priklausomybė nuo dažnio $\omega$ laisva ir atskiru atveju $\eta(\omega)=$ const $(2.9$ pav.). Priklausomybė $\eta$ nuo $\omega$ pagal Foigto hipotezę:

$$
\eta=\frac{h}{c}|\omega|
$$

čia $c$-standumo koeficientas; $h$ - slopinimo charakteristika, gauta iš pasvirusios tiesès (2.9 pav.).

1. Jeigu nuostolių koeficientą (2.53) pakeisime jo pastovia reikšme $\eta_{0}$, nustatyta atliekant bandymus, esant saviesiems sistemos dažniams $\omega_{0}=\sqrt{\frac{c}{m}}$, tuomet

$$
\eta=\frac{h}{c} \omega_{0}=\text { const }
$$

kuri sutampa su reikšme $\eta(2.53)$, kai $|\omega|=\omega_{0}$, tai amplitudinė dažninė charakteristika $x_{0}(\omega)$, nustatyta iš lygties, atitinkamai Foigto hipotezei

$$
m \ddot{x}+h \dot{x}+c x=F_{0} \cos (\omega t+\varphi),
$$

išreiškiamas perduodamumas:

$$
T=\frac{x}{x_{0}}=\frac{1}{\sqrt{\left(1-\frac{\omega^{2}}{\omega_{0}^{2}}\right)^{2}+\eta_{0}^{2} \frac{\omega^{2}}{\omega_{0}^{2}}}},
$$

kuri gerai aproksimuos $\eta(\omega)$. Tai lengvai galima patikrinti, kai slopinimas nepriklauso nuo dažnio $\eta=$ const (2.9 pav.), kuriam perduodamumas suteiks išraišką (Sorokin 1960): 


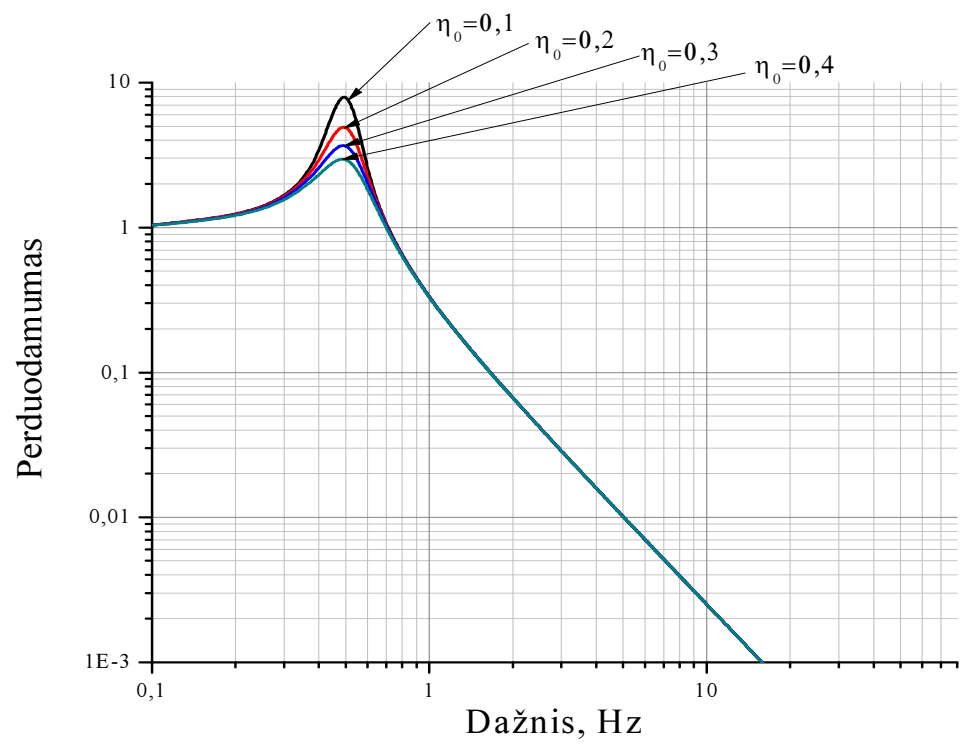

2.10 pav. Perduodamumo grafikai, kai slopinimas atitinka Foigto hipotezę

Fig. 2.10. Transmissibility graphics when damping coincides with the Foigt's hypothesis

$$
T=\frac{x}{x_{0}}=\frac{\sqrt{1+\frac{\eta^{2}}{4}}}{\left(1-\frac{\eta_{0}^{2}}{4}-\frac{\omega^{2}}{\omega_{0}^{2}}\right)^{2}+\eta_{0}^{2}}
$$

Priklausomybès (2.56) ir (2.57), esant ịprastoms reikšmėms, $\eta \leq 0,25$ praktiškai sutampa.

Jeigu platforma (2.7 pav., b) turi atsitiktinius virpesius $x_{0}(t)$, tai vidutine kvadratinè amplitudè turès tokią išraišką (Nashif et al. 1985):

$$
\bar{x}^{2}=\frac{1}{2} \int_{-\infty}^{+\infty} \frac{\left[x_{0}(\omega)\right]^{2} c^{2}\left(1+\eta^{2}\right)}{\left(c-m \omega^{2}\right)^{2} c^{2} \eta^{2}},
$$

čia $\bar{x}_{0}$ - funkcijos $x_{0}(t)$ Furjè atvaizdas arba vidutinis kvadratinis spektrinis lygis. 


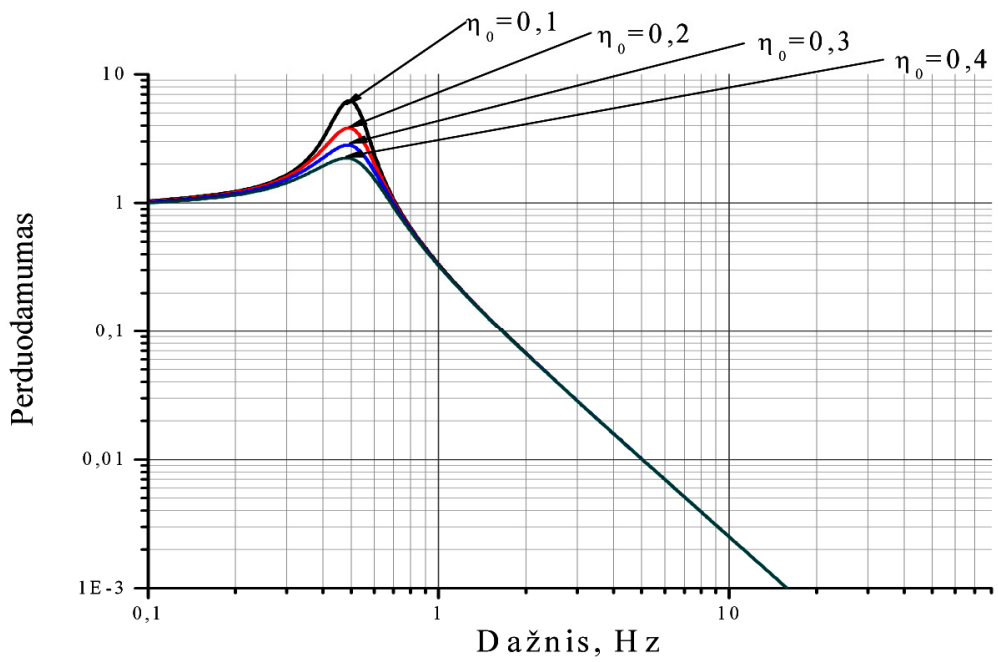

2.11 pav. Perduodamumo grafikai, kai slopinimas nepriklauso nuo dažnio

Fig. 2.11. Transmissibility graphics when damping not depends on frequency

Jeigu dydis $\left[x_{0}(\omega)\right]^{2}$ pastovus, kas būdinga baltajam triukšmui, tai atsitiktinè perduodamumo funkcija bus lygi:

$$
\frac{\bar{x}}{\bar{x}_{0}(\omega)}=\frac{\pi \sqrt{\omega_{0}}}{2 \sqrt{2 \eta}}\left(1+\sqrt{1+\eta^{2}}\right) .
$$

Tai reiškia, kad vidutinè kvadratinè reikšmè $\bar{x} / \bar{x}_{0}(\omega)$ proporcinga $\sqrt{\omega_{0} / \eta}$, kai žadinama platforma ir $\eta \leq 1$. Tokiu būdu atsitiktinę perduodamumo funkciją $\bar{x} / \bar{x}_{0}(\omega)$ galima sumažinti ne tik didinant $\eta$, bet ir mažinant rezonansini sistemos dažni, t. y. projektuojant sistema, reikia atsakingai parinkti spyruokles.

\subsection{Sudètinès virpesių izoliavimo sistemos dinaminiai tyrimai}

Kai kurie autoriai (Jalili 2002; McMahon 2012) ir laboratorijos siūlo naudoti sudètines virpesių izoliavimo sistemas. Tokioms rekomendacijoms patikrinti buvo atlikti sudètinių sistemų tyrimai. 
Sudètinès virpesių izoliavimo sistemos dinaminiai modeliai parodyti 2.12 pav., a, b.

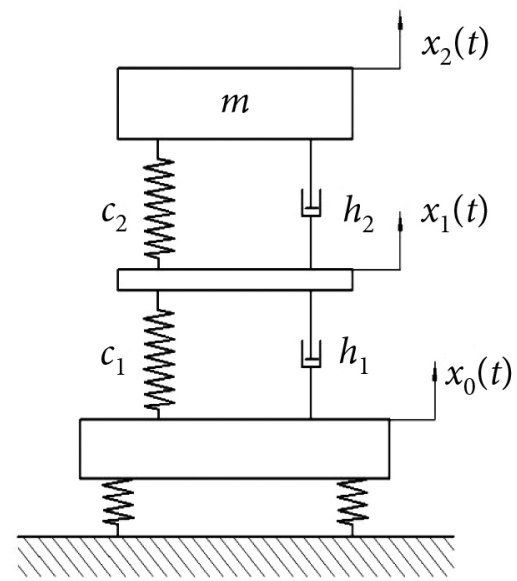

a

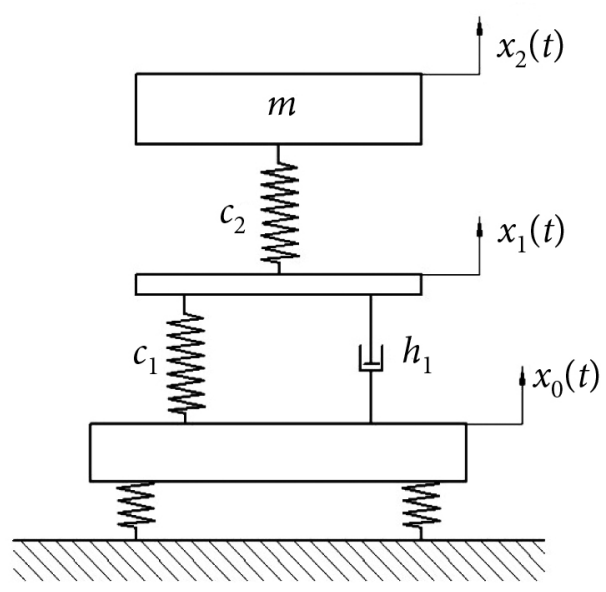

b

2.12 pav. Sudètinès virpesių izoliavimo sistemos dinaminiai modeliai: a - kai kvazinulinio standžio sistema klampiai ir tampriai slopinama; b - kai tik tampriai slopinama

Fig. 2.12. Dynamic models of a complex vibration isolation system: a - when the system of quasi-zero stiffness has viscose-elastic damping;

$\mathrm{b}$ - when only elstic damping

Sistemą sudaro virpanti platforma, optinis stalas su pneumatiniais virpesių izoliatoriais, kai optinès stalo plokštès masè nevertinama ir kvazinulinio standžio virpesiu izoliavimo sistemos su mase $m$.

Sudètinès sistemos (2.12 pav., a, b) judejjimo diferencialinè lygtis turès toki pavidalą:

$$
m \ddot{x}_{2}(t)+h_{j} \dot{x}_{2}(t)+c x_{2}(t)=\left(c+i h_{j} \omega\right) x_{0} \operatorname{expi\omega t},
$$

čia $\xi_{j}=\frac{h_{j}}{2 \sqrt{c j m}},(j=1,2) ; c=\frac{c_{1} c_{2}}{c_{1}+c_{2}}$ 
Šios sistemos perduodamumo koeficientai nustatomi iš lygties (2.60) sprendinio (Gurecki 1970, 1971). Kai platforma yra veikiama kinematinio harmoninio žadinimo $x_{0}(t)=x_{0} \sin \omega t$, absoliutus pagreičio amplitudès perduodamumas lygus:

$$
T_{\ddot{x}_{2}}=\sqrt{\frac{\left[1+4 \xi_{1}^{2}\left(\frac{\omega_{1}}{\omega_{01}}\right)^{2}\right]\left[1+4 \xi_{2}^{2}\left(\frac{\omega_{2}}{\omega_{02}}\right)^{2}\right]}{1+4 \xi_{1}^{2}\left(\frac{\omega_{1}}{\omega_{01}}\right)^{2}\left[1+4 \xi_{2}^{2}\left(\frac{\omega_{2}}{\omega_{02}}\right)^{2}+\left[\left(\frac{\omega_{1}}{\omega_{01}}\right)^{2}+\left(\frac{\omega_{2}}{\omega_{02}}\right)^{2}\right]\right]+F}}
$$

čia $F=4\left(\frac{\omega_{1}}{\omega_{01}}\right)^{2}\left(\frac{\omega_{2}}{\omega_{02}}\right)^{2}\left(\xi_{1} \frac{\omega_{2}}{\omega_{02}}+\xi_{2} \frac{\omega_{1}}{\omega_{01}}\right)^{2}-$

$$
-2\left[\left(\frac{\omega_{1}}{\omega_{01}}\right)^{2}\left(1+4 \xi_{2}^{2} \frac{\omega_{2}}{\omega_{02}}\right)+\left(\frac{\omega_{2}}{\omega_{02}}\right)^{2}\left(1+4 \xi_{1}^{2}\left(\frac{\omega_{1}}{\omega_{01}}\right)^{2}\right)\right] .
$$

Santykinis perduodamumas atitinkamai:

$$
T_{x_{2}-x_{0}}=\sqrt{\frac{\left[\left(\left(\frac{\omega_{1}}{\omega_{01}}\right)^{2}+\left(\frac{\omega_{2}}{\omega_{02}}\right)^{2}\right]^{2}+4\left(\frac{\omega_{1}}{\omega_{01}}\right)^{2}\left(\frac{\omega_{2}}{\omega_{02}}\right)^{2}\left(\xi_{1} \frac{\omega_{2}}{\omega_{02}}+\xi_{2} \frac{\omega_{1}}{\omega_{01}}\right)^{2}\right.}{1+4 \xi_{1}^{2}\left(\frac{\omega_{1}}{\omega_{01}}\right)^{2}\left[1+4 \xi_{2}^{2}\left(\frac{\omega_{2}}{\omega_{02}}\right)+\left[\left(\frac{\omega_{1}}{\omega_{01}}\right)^{2}+\left(\frac{\omega_{2}}{\omega_{02}}\right)^{2}\right]^{2}+F\right]}},
$$

čia $F=4\left(\frac{\omega_{1}}{\omega_{01}}\right)^{2}\left(\frac{\omega_{2}}{\omega_{02}}\right)^{2}\left(\xi_{1} \frac{\omega_{2}}{\omega_{02}}+\xi_{2} \frac{\omega_{1}}{\omega_{01}}\right)^{2}-$

$-2\left[\left(\frac{\omega_{1}}{\omega_{01}}\right)^{2}\left(1+4 \xi_{2}^{2} \frac{\omega_{2}}{\omega_{02}}\right)+\left(\frac{\omega_{2}}{\omega_{02}}\right)^{2}\left(1+4 \xi_{1}^{2} \frac{\omega_{1}}{\omega_{01}}\right)^{2}\right]$.

Skaičiavimo rezultatai parodyti 2.13 pav., a, b. 


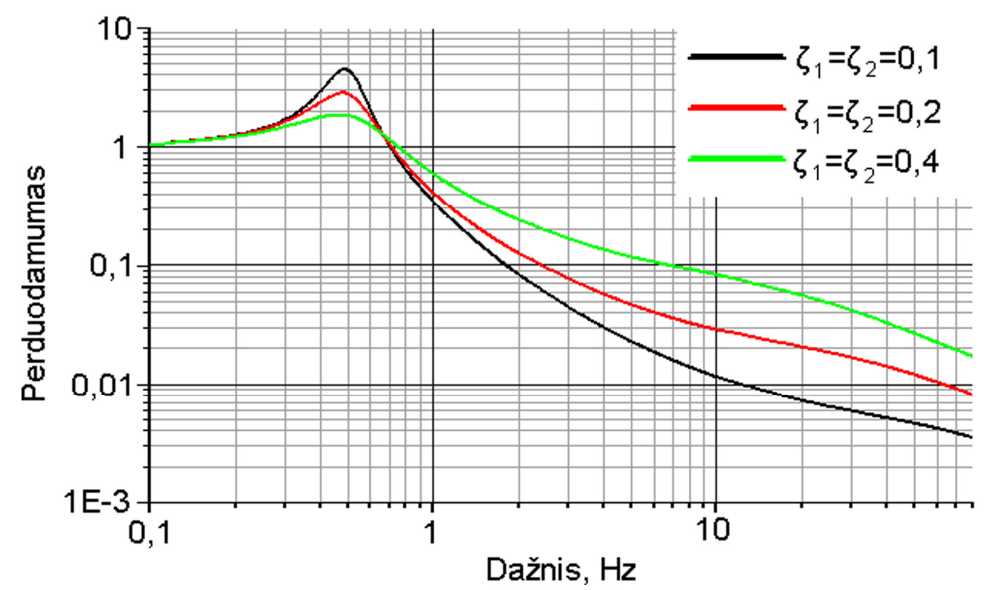

a

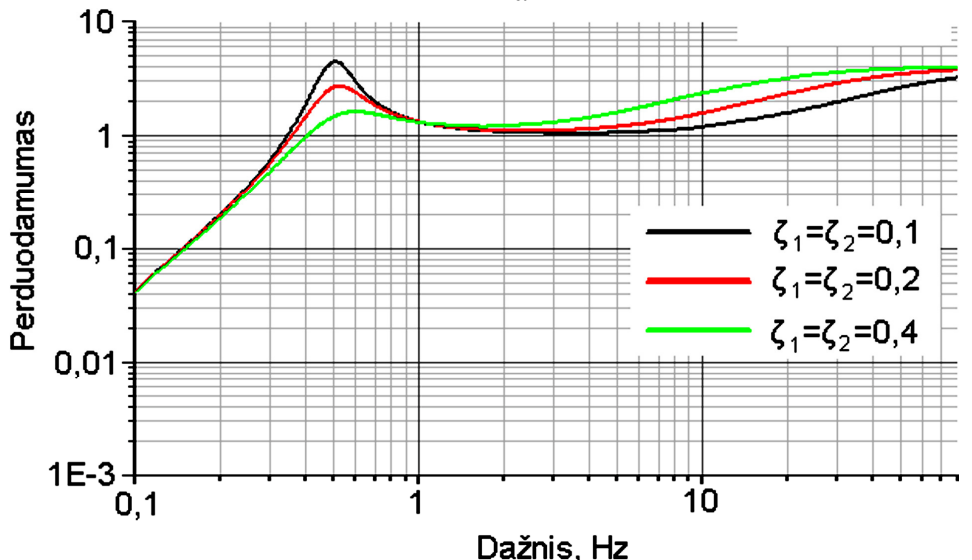

b

2.13 pav. Sudètinès virpesių izoliavimo sistemos perduodamumas:

$\mathrm{a}$ - absoliutinis; $\mathrm{b}$ - santykinis

Fig. 2.13. Transmissibilities of a complex vibration isolation system: $\mathrm{a}$ - absolute; $\mathrm{b}$ - relative

Tuo atveju, kai sudètinès virpesių izoliavimo sistemos kvazinulinio standžio mechanizmas yra tik tampriai slopinamas (2.12 pav., b), o platforma turi kinematinį harmonini žadinimą $x_{0}(t)=x_{0} \sin \omega t$, sistemos absoliutus pagreičio amplitudès perduodamumas bus lygus: 


$$
T_{\ddot{x}_{2}}=\sqrt{\frac{1+4 \xi_{1}^{2}\left(\frac{\omega_{1}}{\omega_{01}}\right)^{2}}{1+4 \xi_{1}^{2}\left(\frac{\omega_{1}}{\omega_{01}}\right)^{2}\left(1+\frac{\omega_{2}^{4}}{\omega_{02}}\right)+\left(\frac{\omega_{1}^{2}}{\omega_{01}^{2}}+\frac{\omega_{2}^{2}}{\omega_{02}^{2}}\right)^{2}-F_{1}}},
$$

čia $F_{1}=2\left[\frac{\omega_{1}^{2}}{\omega_{01}^{2}}+\frac{\omega_{2}^{2}}{\omega_{02}^{2}}\left(1+4 \xi_{1}^{2} \frac{\omega_{1}^{2}}{\omega_{01}^{2}}\right)\right]$.

Santykinis perduodamumas turès tokị pavidalą:

$$
T_{x_{2}-x_{0}}=\sqrt{\frac{\left(\frac{\omega_{1}^{2}}{\omega_{01}^{2}}+\frac{\omega_{2}^{2}}{\omega_{02}^{2}}\right)^{2}+4 \xi_{1}^{2} \frac{\omega_{1}^{2} \omega_{2}^{4}}{\omega_{01}^{2} \omega_{02}^{4}}}{1+4 \xi_{1}^{2}\left(\frac{\omega_{1}}{\omega_{01}}\right)^{2}\left(1+\frac{\omega_{2}^{4}}{\omega_{02}{ }^{4}}\right)+\left(\frac{\omega_{1}^{2}}{\omega_{01}^{2}}+\frac{\omega_{2}^{2}}{\omega_{02}^{2}}\right)^{2}-F_{1}}},
$$

čia $F_{1}=2\left[\frac{\omega_{1}^{2}}{\omega_{01}^{2}}+\frac{\omega_{2}^{2}}{\omega_{02}^{2}}\left(1+4 \xi_{1}^{2} \frac{\omega_{1}^{2}}{\omega_{01}^{2}}\right)\right]$.

Skaičiavimo rezultatai parodyti 2.14 pav., a, b.

Iš 2.13 pav., a, matome, kad esant $\omega / \omega_{0} \geq \sqrt{2}$, virpesių izoliavimo efektyvumas užtikrinamas esant bet kokiam slopinimui, o kai yra 2.13 pav., b, atvejis, virpesių izoliavimo efektyvumas užtikrinamas visame dažnių diapazone, jeigu $\xi>1 / \sqrt{ } 2$, o esant $\xi<1 / \sqrt{ } 2$, diapazone $0<\omega / \omega_{0}<1 / \sqrt{ } 2\left(1-2 \xi^{2}\right)$.

Esant fiksuotam dažniui $\omega / \omega_{0}$, efektyvumo laipsnis dideja didejant slopinimui, kai $\xi=0$, efektyvumo ruožas atitinka $0<\omega / \omega_{0}<1 / \sqrt{ } 2$. Analogiški samprotavimai tinka ir 2.14 pav., a, b.

Jeigu platforma turi kinematinị impulsinį žadinima, tai sistemos diferencialinè lygtis (2.24) bus tokia:

$$
\ddot{x}_{2}+2 n_{j} \dot{x}_{2}+\omega_{0}^{2} x_{2}=\frac{1}{m} F(t),
$$

čia $n_{j}=\frac{n_{j}}{2 m} ; \xi_{j}=\frac{h_{j}}{2 \sqrt{c j m}} ;(j=1,2) ; \omega_{0}^{2}=\frac{c}{m} ; c=\frac{c_{1} c_{2}}{c_{1}+c_{2}}$. 


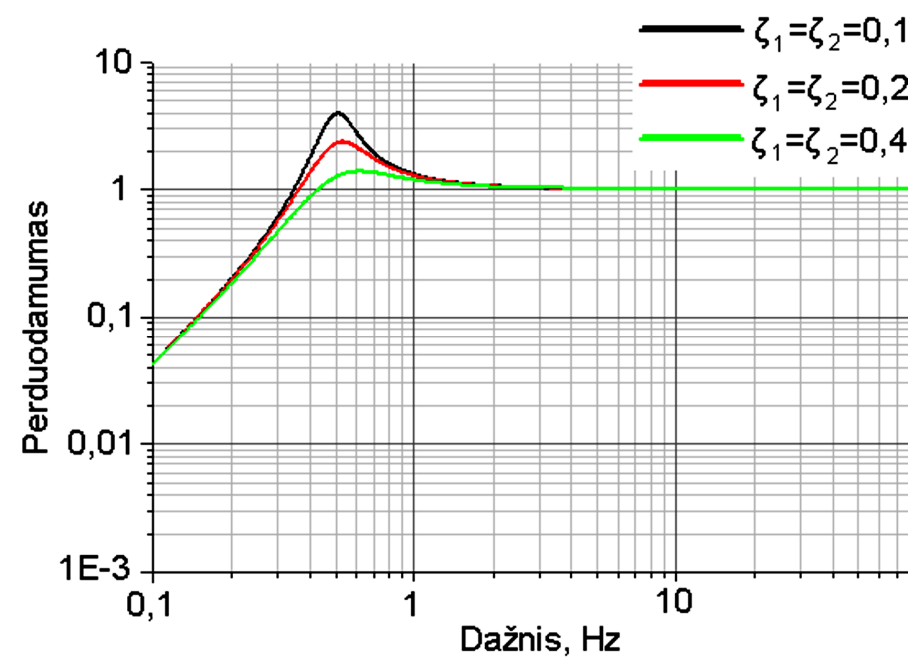

a

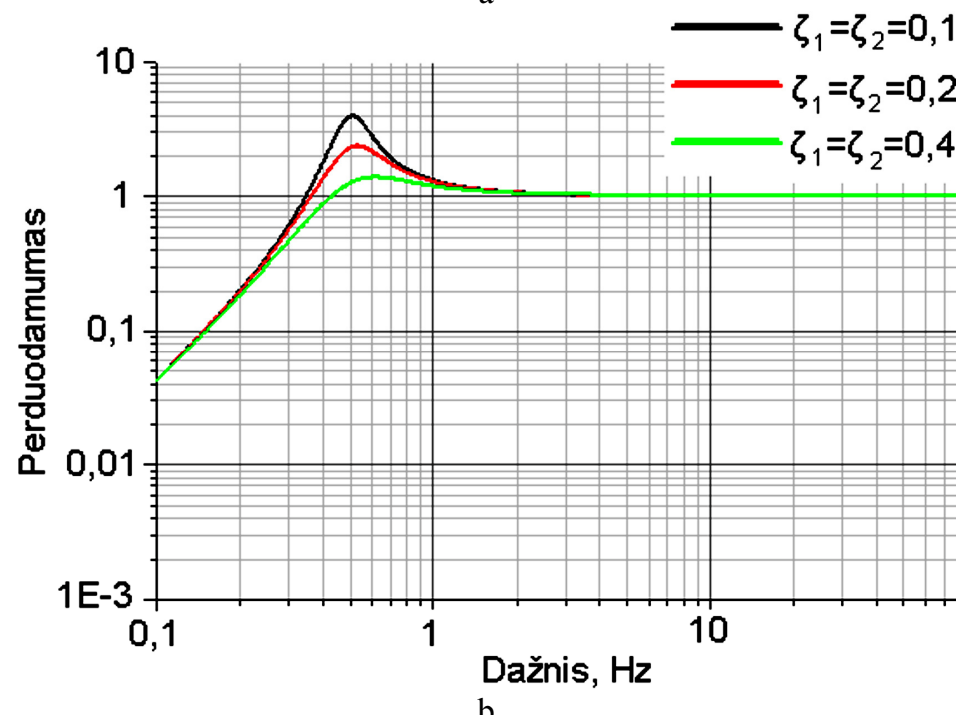

b

2.14 pav. Sistemos (2.12 pav., b) absoliutus (a) ir santykinis (b) perduodamumas

Fig. 2.14. Transmissibilities of a system (Fig. 2.12 b) absoliute (a) and relative (b)

Padinèmis sąlygomis

$$
x_{2}(0)=x_{0} ; \dot{x}_{2}(0)=\dot{x}_{0} .
$$

Kai sistemą veikia vienetinis akimirksnis impulsas $\delta(t-\tau)$ laike $t=\tau$ nulinèmis pradinèms salygomis. Tuomet lygties (2.65) sprendinys, vadinamas impulsine perejjimo funkcija $h(t, \tau)$, lygus (Čirkov 1975): 


$$
h(t, \tau)=\left\{\begin{array}{l}
0, \quad t \leq \tau \\
\frac{1}{\omega_{n_{j}}} e^{-n_{j}(t-\tau)} \sin \omega_{n_{j}}(t-\tau), \quad t>\tau
\end{array}\right\}
$$

čia $\omega_{n_{j}}=\sqrt{\omega_{0}^{2}+n_{j}^{2}}$.

Jeigu lygtyje (2.65) jègą $F(t)$ sudaro be galo maži impulsai $F(\tau) d \tau$, tai sumuodami sistemos reakciją nuo kiekvieno tokio impulso laiko réžiuose $[0, t]$ gausime dalinị lygties (2.65) sprendini, vadinamą Diuamelio integralu:

$$
x_{2} \cdot(t)=\frac{1}{m} \int_{0}^{t} h(t, \tau) F(\tau) d \tau .
$$

Naudodamiesi (2.67) išraiška galime rasti bematę funkciją $x_{2}(t) m \omega_{j}^{2} / F_{0}$, nusakančią sistemos reakciją veikiant jègai $F(t)=F_{0} f(t)$.

Skaičiavimo rezultatai vienetinei impulsinei funkcijai $f(t)=F(t) / F_{0}$ bus lygūs:

$$
\frac{x_{2}(t) m \omega_{n_{j}}^{2}}{F_{0}}=\frac{\omega_{n_{j}}^{2}}{\omega^{2}}\left[1-e^{-n_{j} t}\left(\cos \omega_{n_{j}} t+\frac{n_{j}}{\omega_{n_{j}}} \sin \omega_{n_{j}} t\right)\right] .
$$

Sakykime, sistemą veikia vienodais laikotarpiais $\tau$ vienodi smūginiai stačiakampès formos impulsai (2.15 pav.). Kai $\tau$ sutampa su svyravimų periodu $T_{n_{j}}=2 \pi / \omega_{n_{j}}$, gauname smūginị rezonansą.

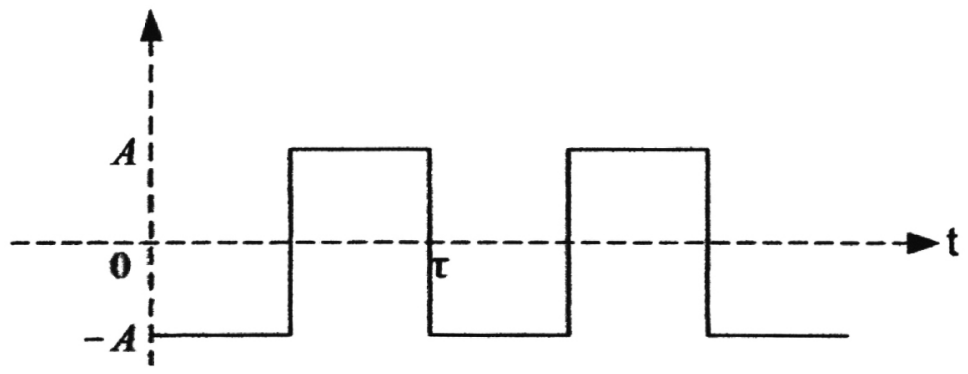

2.15 pav. Smūginiai stačiakampès formos impulsai

Fig. 2.15. Impact impulses of a staright angular form 
Šiuo atveju:

$$
\frac{x_{2} m \omega_{n_{j}}^{2}}{F}=\frac{1-\exp \left(-n n_{j} T_{n_{j}}\right)}{1-\exp \left(-n T_{n_{j}}\right)} e^{-n_{j} t_{1}} \sin \omega_{n_{j}} t, \quad t_{1}>0,
$$

Čia $t_{1}=t-(n-1) T_{n_{j}} ; n$-impulsų skaičius; $F=\lim _{\tau \rightarrow 0} F_{0} \tau-$ smūginis impulsas (Bolotin, 1978).

Maksimali reikšmè, lyginant su vienetinio impulso poveikiu padidèja $\left[1-\exp \left(-n n_{j} T_{n_{j}}\right)\right]\left[1-\exp \left(-n_{j} T_{n_{j}}\right)\right]^{-1}$ karto. Kai $n_{j}=0$, padidejjimas vyks $n$ kartų.

Tuo atveju, kai platformos virpesiai sudaro stacionarų atsitiktini procesa, vadinamą baltuoju triukšmu, sistemos diferencialinè lygtis gali būti užrašyta taip:

$$
m \ddot{X}_{2}(t)+h_{j} \dot{X}_{2}(t)=c X_{2}(t)=h_{j} \dot{X}_{0}(t)+c X_{0}(t),
$$

čia $x_{0}(t)$ - stacionarus atsitiktinis procesas.

Stacionaraus atsitiktinio proceso matematinè viltis lygi nuliui. Dispersija $D_{X_{0}}$ ir koreliacinė funkcija $k_{X_{0}}(\tau)$ išreiškiama per spektrini tankị $S_{X_{0}}(\omega)$ proceso $X_{0}(t)$.

$$
\begin{gathered}
D_{X_{0}}=\frac{1}{\pi} \int_{0}^{\infty} S_{X_{0}}(\omega) d \omega, \\
k_{X_{0}}=\frac{1}{\pi} \int_{0}^{\infty} S_{X_{0}}(\omega) \cos \omega \tau d \omega .
\end{gathered}
$$

Savo ruožtu spektrinis tankis $S_{X_{0}}(\omega)$ susietas su koreliacine funkcija $k_{X_{0}}(\tau)$ sąryšiu (Benaroya 2004)

$$
\begin{gathered}
S_{X_{0}}(\omega)=\frac{1}{\pi} \int_{0}^{\infty} k_{X_{0}}(\tau) \cos \omega \tau d \tau, \\
S_{X_{2}}(\omega)=|H(\omega)|^{2} S_{X_{0}}(\omega) .
\end{gathered}
$$

Tegul $S_{\ddot{X}_{2}}(\omega)$ - masės svyravimo pagreičio amplitudès spektrinis tankis, o $S_{X_{0}}(\omega)$ - platformos, tuomet 


$$
S_{\dot{X}_{2}}(\omega)=|H(\omega)|^{2} S_{X_{0}}
$$

Iš šios lygties gauname:

$$
|H(\omega)|^{2}=\frac{1}{\left(\omega_{0}^{2}-\omega^{2}\right)^{2}+\left(2 \varsigma \omega_{0} \omega\right)^{2}} .
$$

Skaičiavimo rezultatai parodyti 2.16 pav.

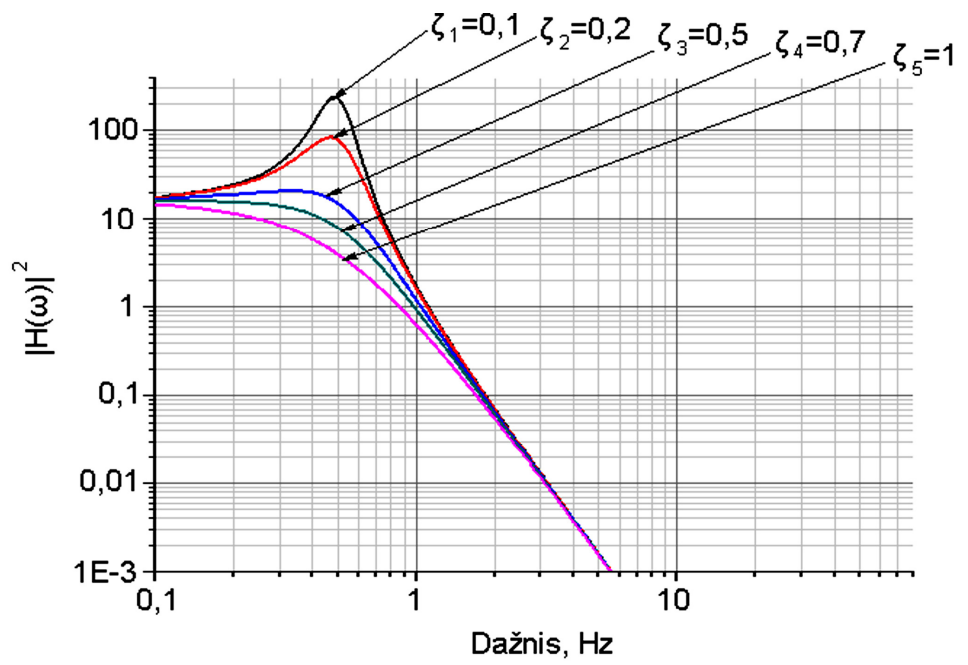

2.16 pav. Perduodamumo funkcijos modulio kvadratas

Fig. 2.16. Square of a module of a transmissibility function

Kai kuriais atvejais galima naudotis tokia išraiška:

$$
H(\omega)=\frac{D_{X_{2}}}{D_{X_{0}}} \leq 1,
$$

čia $D_{\ddot{x}_{2}}$ ir $D_{\ddot{x}_{0}}-$ virpesių pagreičių amplitudžių dispersijos.

Sistemos virpesių izoliavimo efektyvumas bus pasiektas, kai $H(\omega) \leq 1$. 


\subsection{Antrojo skyriaus išvados}

1. Analitiškai ištirtos optinių stalų dinaminès charakteristikos ir nustatyta, kad optinių stalų su pneumatiniais virpesių izoliatoriais rezonansinis dažnis svyruoja nuo 3 iki $4 \mathrm{~Hz}$, o virpesių izoliavimas prasideda nuo $5 \mathrm{~Hz}$ dažnio.

2. Mechaninès koncepcijos kvazinulinio standžio žemojo dažnio virpesių izoliavimo sistemos analitinis tyrimas parodè, kad virpesių izoliavimas prasideda nuo 0,7 Hz dažnio. Dažniui didèjant izoliavimo efektyvumas didejja. Remiantis tyrimu gautas kvazinulinio standžio virpesių izoliavimo sistemos patentas.

3. Ištirti sudètinès virpesių izoliavimo sistemos dinaminiai parametrai ir nustatyta, kad tokios sistemos gerai slopina žemojo dažnio virpesius nuo $0,8 \mathrm{~Hz}$, kai optinio stalo plokštės masė nevertinama. 


\section{Optinių staly ir platformos dinaminių charakteristiku eksperimentiniai tyrimai}

Skyriuje nagrinejjami optinių stalų ir platformos dinaminių charakteristikų eksperimentiniai tyrimai. Ištirti optinių stalų stalviršiai ir platforma bei pneumatiniai izoliatoriai, žadinant pagrindą harmoniniais, impulsiniais ir atsitiktiniais virpesiais. Skyriaus originalumą nusako korinès konstrukcijos plokščiu, platformos ir virpesių izoliavimo atramų eksperimentinių tyrimų ir dinaminių parametrų nustatymo metodika. Šio skyriaus medžiaga paskelbta autoriaus publikacijoje (Berba 2012)

\subsection{Optinių stalų su pneumatiniais virpesių izoliatoriais eksperimentiniai tyrimai}

Optinio stalo su pneumatiniais virpesių izoliatoriais tyrimo stendas parodytas 3.1 paveiksle. 


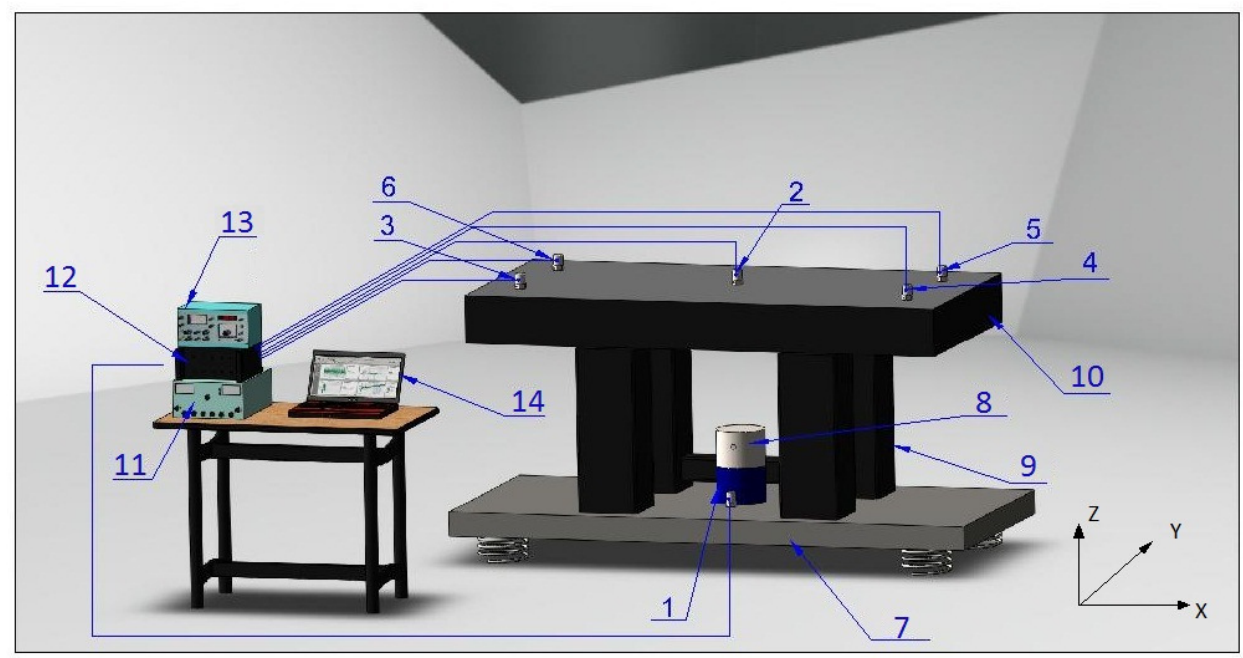

3.1 pav. Optinio stalo dinaminių charakteristikų tyrimo schema: 1, 2, 3, 4, 5, 6 - virpesių jutikliai; 7 - platforma (pagrindas); 8 - vibratorius; 9 - virpesių izoliavimo atramos; 10 optinis stalas su bandomosiomis virpesių izoliacinėmis atramomis; 11 - impulsinis generatorius; 12 - stiprintuvas; 13 - generatorius; 14 - kompiuteris su analizatoriumi. Virpesių žadinimo kryptys: Z - vertikali; Y - horizontali skersine; X - horizontali išilginè

Fig. 3.1. Sceme of research of dymanic characteristics of an optical tabale: 1, 2, 3, 4, 5, 6 - vibration transducers; 7 - paltform (base); 8 - vibrator; 9 - supports of vibration isolation; 10 - optical tabale with experimental of vibration isolation; 11 - impulse generator; 12 - amplifier; 13 - generator; 14 - computer with analyser. Directions of vibration excitation: $\mathrm{Z}$ - vertical; $\mathrm{Y}$ - horizontal transverse; $\mathrm{X}$ - horizontal longitudinal

Tyrimo objektai, matavimo priemonès ir iranga. Tiriamojo optinio stalo viršutine ir apatinè stalviršio plokštumos yra pagamintos iš šaltai valcuoto feromagnetinio plieno lakštų kuriuos jungia lengva, iš korozijai atsparaus plieno suformuota korine konstrukcija, suteikianti stalui išskirtinių standumo savybių. Optinis stalas paprastai montuojamas ant specialių virpesius izoliuojančių atramų. Šių optinio stalo konstrukcijų atsparumas statiniu ir dinaminiu jègų poveikiui ne tik vertikalia, bet ir horizontalia kryptimi laikomi labai svarbiais kokybę apibūdinančiais veiksniais.

Idealizuota optinių stalų „seisminio“ montavimo sistema - standus stalas, sumontuotas ant masyvaus pamato arba ant virpesius slopinančiu atramų. Pasaulinejje praktikoje naudojamos ivvairių konstrukcijų virpesių izoliavimo atramos su pneumatiniais amortizatoriais. Šios atramos turi užtikrinti stalo stabilumą vertikalia ir horizontalia kryptimis. Horizontalių aplinkos virpesių poveikis ypač ryškus, kai laboratorijos įrengiamos viršutiniuose pastatų aukštuose. 
Dinaminių ir statinių jègu poveikiui atsparių objektų gamybai dažnai naudojamos lengvos korinès konstrukcijos. Korio savybes lemia narvelių dydis, sienelių storis, medžiaga, iš kurios jie pagaminti ir kt. Korinèms konstrukcijoms būdingos savybès - lengvumas ir atsparumas gniuždymui bei lenkimui. Šios savybès ypač svarbios, kai reikalaujama optimalaus masès ir standumo charakteristikų santykio. Kaip tik dèl to korinès konstrukcijos naudojamos lèktuvų, sraigtasparnių ir pan. irenginių gamyboje.

Šio tipo konstrukcijos plačiai naudojamos optiniams laboratoriniams stalams. Koriniai stalai turi gerų virpesių slopinimo savybių, jie yra kur kas lengvesni nei masyvūs, iš granito pagaminti stalai. Daugeliu atvejų pasirenkamas ne atsparus mechaninèms apkrovoms sunkus granitinis stalas, bet lengva koriné konstrukcija.

Svarbiausias izoliacinių atramų kokybès kriterijus - mechaninių virpesių perduodamumas iš pagrindo per atramas $\mathfrak{i}$ stalvirši charakteristikos. Šioms charakteristikoms nustatyti taikomi ịvairūs eksperimentiniai metodai. Konkretus metodas parenkamas atsižvelgiant $\mathfrak{i}$ daugeli veiksnių, tarp kurių vienas svarbesniujų yra dominuojančių dažnių diapazonas.

Tyrimams naudota virpesių ir kitu dinaminių charakteristikų matavimo bei analizès aparatūra: firmos „Brüel\&Kjaer“ smūginis plaktukas 8202 su jègos matavimo keitliu 8200, stiprintuvas 2626 ir kilnojamoji matavimo rezultatu apdorojimo įranga „Machine Diagnostics Toolbox Type 9727“ su kompiuteriu DEEL, virpesiu jutikliai 8341, 8306 su virpesių matuokliu 2511 ir kt.

Pneumatinių virpesių izoliatorių dinaminių parametrų tyrimams naudota ir išbandyta virpesių sužadinimo platforma su vibratoriumi bei kita speciali tyrimų iranga, taip pat sukurta nauja lengvai perderinama virpesių sužadinimo platforma, leidžianti sužadinti bandomojo objekto virpesius $1-50 \mathrm{~Hz}$ dažnių juostoje bet kuria iš trijų krypčių - vertikalia, horizontalia skersine ar horizontalia išilgine kryptimi.

Matavimų ir tyrimų metodikos. Tyrimo tikslas - parengti ir aprobuoti pneumatinių virpesių izoliatorių bei korinès konstrukcijos optinių stalų dinaminių charakteristikų nustatymo metodikas, atlikti tyrimus, ivvertinus pripažintų pasaulyje firmų „NEWPORT“, „TMC“, „MELLES GRIOT“ ir kitu gamintojų patirti bei prototipus.

Kiekvienas kietasis kūnas, veikiamas išorinių statinių ar dinaminių jẻgų, deformuojasi. Šie reiškiniai ypač svarbūs optiniams stalams, ant kuriu stalviršio darbinès plokštumos pastatomi ar pritvirtinami îvairūs optiniai elementai ir atliekami preciziniai matavimai. Stalai turi neprarasti svarbiausių mechaninių savybių - formos stabilumo, stalviršio plokštumo ir kitų parametrų ne tik dèl statinių apkrovų. Labai dažnai nepageidautinus reiškinius sukelia dinaminès jègos. Intensyviausiai išoriniu jègų ar kitų veiksnių sukeliamų virpesių itaka pasireiškia kiekvienai konstrukcijai būdinguose rezonansiniuose dažniuose. Žalingi veikian- 
čių mašinų (staklių, transporto priemonių ir kitų mechanizmų) sukeliami virpesiai per pamatus ir komunikacijas perduodami net ir toliau esantiems objektams. Svarbu taip suprojektuoti gamini, kad šių vertikalia ir horizontalia kryptimi veikiančių jègu itaka būtų minimali, o rezonansinè zona būtų kuo toliau nuo dažniausiai pasitaikančių ir charakteringiausių darbo metu virpesių. Virpesių izoliavimo sistema turi filtruoti grindu (pamato) virpesius dar nepasiekus stalo paviršiaus. Optinių stalų atsparumas virpesių poveikiui pasaulineje praktikoje laikomas bene svarbiausiu techniniu parametru.

Korinès konstrukcijos stalo optinès plokštès dinaminiu charakteristiku tyrimo metodika. Korinès konstrukcijos optinių plokščiu buvo tiriamos šios dinaminès charakteristikos:

- virpesių pagreičio laiko charakteristika;

- dinaminis slankis (10-1000) Hz dažnių juostoje (Compliance);

- nustatomi pirmieji rezonansiniai dažniai;

- skaičiuojamas dinaminis ilinkio koeficientas DIL (Dynamic Deflection Coefficient - DDQ);

- skaičiuojamas maksimalus reliatyvusis plokštès judejjimas (Maximum Relative Tabletop Motion - MRTM).

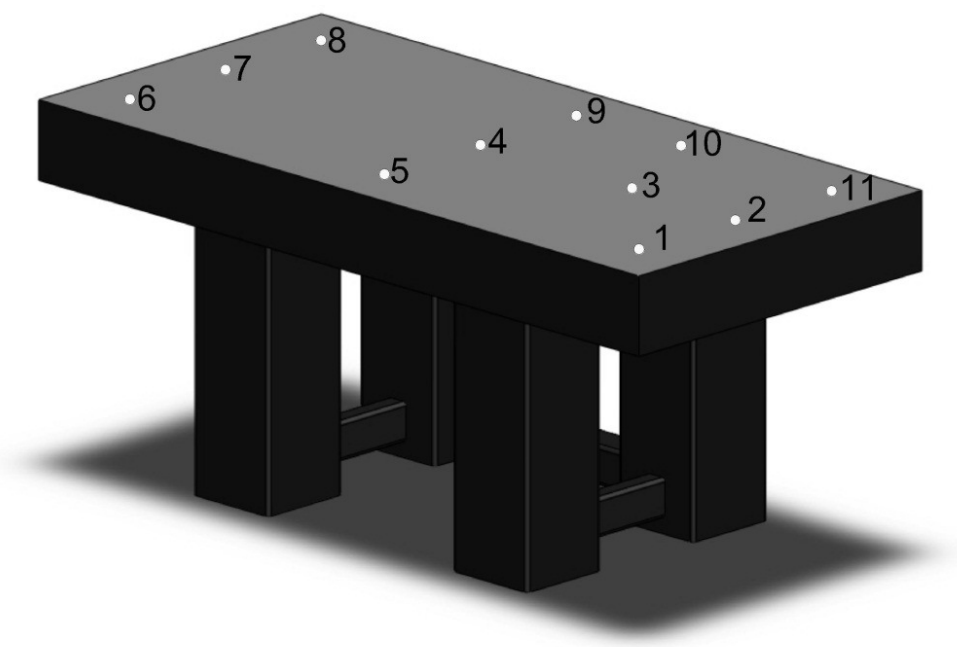

3.2 pav. Korinės konstrukcijos optinè plokštė su pažymètais matavimo taškais

Fig. 3.2. Optical plate of comb design with marked measuring points

Stalviršis padalijamas i sektorius, kuriuose pažymimi matavimo taškai (3.2 pav.). Iš praktikos žinoma, kad mazginiuose taškuose virpesių amplitudès yra minimalios arba tie taškai visiškai nevirpa. Gretimuose taškuose galimi kiti 
procesai. Tyrimo tikslas - nustatyti blogiausius stalviršio taškus ir juose atlikti matavimus.

Ivertinus tyrimų rezultatus ir minètų firmų rekomendacijas buvo įsitikinta, kad didžiausios virpesių amplitudès ir daugiausiai rezonansinių dažnių yra prie stalo kampų. Pasirinktos matavimo vietos apie $150 \mathrm{~mm}$ nuo stalo kampų. Matavimo vietas pasirenkant arčiau kampo, pastebèti nestabilūs rezultatai kartojant matavimus.

Dinaminio slankio priklausomybę nuo dažnio galima nustatyti keletu būdų. Vienas jų - veikti stalą pasirinktame paviršiaus taške pastovios amplitudès harmonine kintamo dažnio jèga ir matuoti stalo paviršiaus virpesius. Šis būdas sunkiai igyvendinamas dèl techninių priežasčių.

Kitas būdas - smūgiu sužadinti stalo virpesius (delta funkcija) ir matuoti virpesių atsaką.

Korinès konstrukcijos optinių plokščių dinaminio slankio priklausomybè nuo dažnio buvo nustatoma sužadinant virpesius smūginiu būdu. I kiekvieną pažymètą stalviršio tašką (3.2 pav.) suduodama po 10 smūgių specialiu plaktuku 8202 su jègos matavimo keitliu 8200, stiprintuvu 2626 (3.3 pav.). Greta smūgio vietos pritvirtinamas virpesiu jutiklis. Bandomojo objekto reakcija į smūgi reikiamame dažnių ruože fiksuojama kilnojamaja matavimo rezultatų apdorojimo iranga "Machine Diagnostics Toolbox Type 9727" su kompiuteriu DEEL.

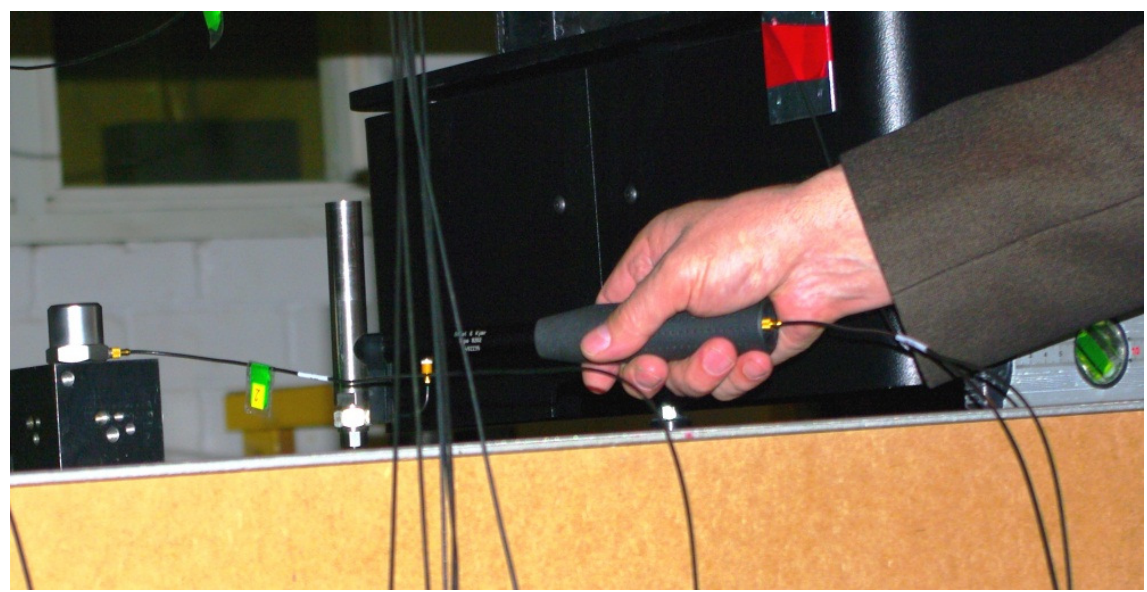

3.3 pav. Korinės konstrukcijos optinės plokštės dinaminių charakteristikų nustatymas pažymètuose taškuose

Fig. 3.3. Definition of dynamic characteristics of an optical plate of comb design at marked points

Visų dešimties matavimų rezultatai suvidurkinami. Gaunama optinės plokštès stalviršio slankio kreivè ir virpesiu pagreičio laiko charakteristika. Korinès 
konstrukcijos optinès plokštės virpesių pagreičio laiko charakteristikos pavyzdys pateiktas 3.5 pav., o dinaminio slankio kreivès pavyzdys - 3.6 pav.

Iki $80 \mathrm{~Hz}$ stalą galima laikyti idealiai standžių kūnu, kai slankis mažèja atvirkščiai proporcingai dažnio kvadratui $(\omega=2 \pi f)$. Šią išraišką atspindi tiesè (3.6 pav.), pagal ją skaičiuojamas stiprinimo faktorius $Q$. Esant dažniams, didesniems nei $80 \mathrm{~Hz}$, slankio kreivè pradeda nukrypti nuo idealiai standaus kūno tiesès. Stalas nebegali būti laikomas idealiai standžiu kūnu, nes, veikiamas virpesiu, jis pradeda deformuotis. Pirmasis rezonansinis dažnis yra lygus $199 \mathrm{~Hz}$.

Virpesiu izoliatoriu efektyvumo ivvertinimas. Izoliatoriumi (3.1 pav.) laikoma atrama 9, dažniausiai paslanki, kurios funkcija - sumažinti smūgio ir/arba grindų virpesių itaką konkrečiam objektui, nagrinejjamu atveju - optinès plokštės stalviršiui 10 ir prie jo pritvirtintiems preciziniams elementams. Slopintuvas sumažina aplinkos virpesius tam tikrame dažnių ruože, sugerdamas ir išsklaidydamas energiją.

Virpesių izoliatoriu charakteristikų nustatymas atliekamas tiriamajai sistemai suteikiant harmonini žadinimą ir palaikant pastovų poslinkị. Virpančios platformos sukūrimas ir tinkamų ypač žemų dažnių virpesių parametrų matavimo priemonių parinkimas, pritaikymas bei įdiegimas parodè, kad tai nėra lengvai išsprendžiama problema. Suprojektuoti ir išbandyti keli virpesių tyrimų įrangos variantai. Tyrimų stendo virpančios platformos pagrindui panaudotas UAB „Standa“ korinès konstrukcijos optinio stalo ruošinys.

Sukurtas ir išbandytas platformos virpesių žadinimo su reguliuojamojo standžio pneumatinemis atramomis eksperimentinis pavyzdys su elektromagnetiniu vibratoriumi. Konstrukcijoje numatyta, kad tyrimus būtų galima atlikti ne tik tyrimu laboratorijoje, bet ir kitose (produkcijos gamybos ar eksploatacijos) vietose. Tyrimų įranga leidžia nustatyti pneumatinių virpesių izoliatorių dinaminius parametrus:

- virpesių perduodamumo vertikalia ir horizontalia kryptimi charakteristikas (1-50) Hz dažnių ruože;

- rezonansinius dažnius (vertikalia ir horizontalia kryptimi);

- slopinimo efektyvumą minètame dažnių ruože.

Virpesių izoliatoriai efektyvūs tik tam tikrame dažnių ruože. Informacijos šaltiniuose (firmos „NEWPORT“, „MELLES GRIOT“ ir „TMCRG“ 2002) pateikiama, kad esant $10 \mathrm{~Hz}$ dauguma pneumatinių izoliatorių filtruoja daugiau nei $90 \%$ grindų virpesių.

Perduodamumo charakteristika (Vibration Response) ir perduodamumo (Transmissibility) kreivè apibūdina virpesių izoliatoriaus mechaninio filtravimo savybes.

Perduodamumo funkcija - santykinis matas, pateikiamas kaip virpesių amplitudžių izoliatoriaus viršutiniame taške ir ant grindų (pamato) santykis. Izoliato- 
rių perduodamumo koeficientas $T$ (TMCRG 2002) yra virpesių (virpesių poslinkio amplitudès) dalis, perduodama iš aplinkos stalviršiui:

$$
T=\frac{X_{s t}}{X_{g r}},
$$

čia $X_{s t}$ - naudingosios apkrovos poslinkio amplitude; $X_{g r}$ - grindų (pamato) virpesių poslinkio amplitudè.

Optinių stalų su amortizuojančiomis atramomis (slopintuvais) sistemos stalviršio judesio ir grindų (pamato) reakcijos santykio dažninė funkcija yra pagrindine izoliatorių charakteristika, vadinama izoliatoriaus perduodamumu (Transmissibility). Neretai ji išreiškiama decibelais $(\mathrm{dB})$ :

$$
T=20 \log _{10}\left[\frac{X_{s t}}{X_{s t}}\right] .
$$

Izoliatoriaus perduodamumas smarkiai krinta esant dažniams, viršijantiems izoliatoriaus rezonansą. Paprastai dominantys dažniai yra daugiau nei $10 \mathrm{~Hz}$, kur perduodami virpesiai privers stalvirši išlinkti ar illinkti. Praktikoje izoliavimo sistemos perduodamumo funkcijos matavimas gali būti iškraipomas kitų triukšmo šaltinių veikiančių naudingają apkrovą (pvz., akustiniai triukšmai). Tai viena priežasčiuc, dèl kurios išmatuotos perduodamumo funkcijos gali neteisingai pavaizduoti sistemos charakteristikas žemuosiuose virpesių lygiuose.

Virpesiu izoliavimo atramu dinaminiu charakteristiku tyrimo metodika. Virpesių izoliavimo atramų dinaminems charakteristikoms tirti buvo suprojektuota ir išbandyta speciali virpesių kinematinio žadinimo platforma. Joje panaudota atitinkamų matmenų platforma ir virpesių žadinimo vibratorius. Vertikaliųjų virpesių žadinimo platformos schema pateikta 3.1 pav. Vibratorius veikia ant pneumatinių atramų esančią platformą ir suteikia jai harmonini judesị. Virpesių dažnis keičiamas keičiant vibratoriaus generatoriaus dažni ruože nuo $1 \mathrm{~Hz}$ iki 50 Hz. Tokia kinematinè schema gana tiksliai užtikrina virpesių žadinimą vertikalia kryptimi. Virpesių amplitudè skersine kryptimi ir vertikaliujų virpesių platformos plokštès paviršiuje amplitudès netolygumas dažnių ruože nuo $1 \mathrm{~Hz}$ iki $50 \mathrm{~Hz}$ neviršija kelių procentų nuo vertikaliujų virpesių amplitudès.

Virpesių izoliavimo atramų dinaminių charakteristikų matavimo ir analizès schema pateikta 3.1 pav. Tyrimo metu ant virpančios platformos plokštès 7 pritvirtinamas virpesiu jutiklis 1. Antrasis virpesiu jutiklis 2 tvirtinamas ant bandomosios optinès plokštės 10, pastatytos ant tiriamujų virpesiu izoliavimo atramų ir sudarančios naudingosios apkrovos dalį. Keitikliai tvirtinami virpesių žadinimo kryptimi apatinès ir viršutinės plokštės centre. Matuoti naudojamas firmos „Bruel\&Kjaer“ analizatorius PULSE 3560C su virpesių jutikliais 751- 
100. Tyrimai buvo atliekami be papildomos apkrovos arba su papildoma $100 \mathrm{~kg}$, $250 \mathrm{~kg}$ ir $500 \mathrm{~kg}$ tolygiai paskirstyta apkrova (3.7 pav.).

3.2 pav. pateikta virpesių kinematinio žadinimo platformos suderintos horizontalios krypties virpesiams žadinti schema. Kadangi šiuo atveju jèga veikia žemiau sistemos masès centro, atsiranda sukimo momentas, todèl žadinami ir slenkamieji horizontalūs ir sukamieji (mūsų atveju parazitiniai) virpesiai. Sukamiesiems virpesiams pašalinti platforma (pagrindas) 2 pastatoma ne tik ant amortizuojančių pneumatinių atramų, bet ir ant specialių standžių riedejjimo atramų, stabilizuojančių virpančios platformos plokštės 2 padèti vertikalia kryptimi, tačiau netrukdančiu horizontaliam plokštès judesiui. Žadinant horizontalia kryptimi, pneumatinès kameros atlieka spyruoklių funkciją tik horizontalia kryptimi.

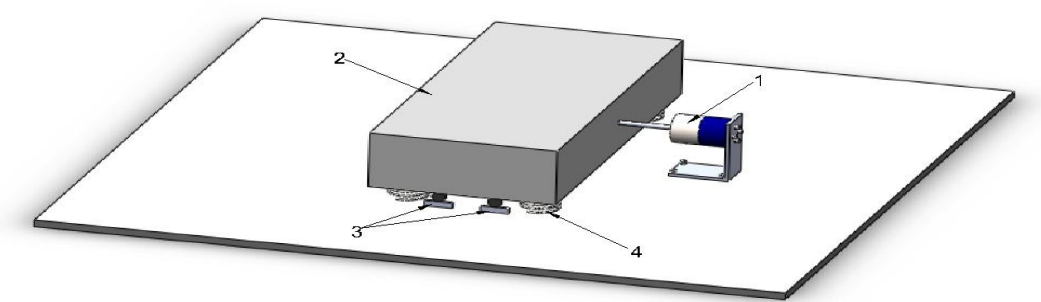

3.4 pav. Horizontaliujų skersinių virpesių kinematinio sužadinimo schema:

1 - vibratorius; 2 - virpanti platforma; 3 - riedejjimo atramos; 4 - pneumatinès atramos

Fig. 3.4. Scheme of kinematic excitation of horizontal transverse vibrations: 1 - vibrator;

2 - vibrating platform; rolling supports; 4 - pneumatic supports

Virpesių žadinimo vibratoriaus antgalis i̇remtas i platformą fiksuotame taške, harmoninis judesys perduodamas virpančiai platformai 2, ant kurios montuojamas bandomasis objektas. Šis virpesiu sužadinimo stendas nesunkiai perderinamas ir pritaikomas horizontalios išilginès krypties virpesiams žadinti - tuo atveju virpesių žadinimo ịrenginys perkeliamas ir pastatomas taip, kad vibratorius suteiktų platformai išilginị horizontalios krypties judesį (kita kryptimi pasukamos ir riedejjimo atramos).

Perduodamumo koeficientas $T$ nustatomas tokiu būdu. Žadinamos platformos virpesiai ir išmatuojama platformos virpesių amplitudè $x_{g r}$ bei virpesių izoliavimo atramų apkrovos (viršutinio stalo) virpesių amplitudè $x_{s t}$. Perduodamumo koeficientas skaičiuojamas pagal (3.1) formulę.

Matavimai kartojami pakeičiant žadinimo dažnị ir tokiu būdu gaunama perduodamumo koeficiento priklausomybè nuo dažnio visame mus dominančiame dažnių ruože (nuo $1 \mathrm{~Hz}$ iki $50 \mathrm{~Hz}$ ). 


\subsection{Stalo optinès plokštès ir platformos dinaminių charakteristiku eksperimentinio tyrimo ir skaičiavimo pavyzdžiai}

Korinès konstrukcijos optinès plokštès dinaminès charakteristikos nustatomos pagal metodika, aprašytą 3.1 skyriuje. Vykdant tyrimus buvo išbandytos dvi plokštės: korinès konstrukcijos optiné plokšte ir platforma, kuri taip pat buvo naudojama kaip pagrindas išbandant virpesių izoliavimo atramas. Matavimai buvo atlikti vienuolikoje taškų, kaip parodyta 3.2 pav. Tyrimo metu nustatytos virpesių pagreičio laiko charakteristikos ir dinaminio slankio (Compliance) priklausomybė nuo $10 \mathrm{~Hz} 1000 \mathrm{~Hz}$ dažnių ruože. Iš dinaminio slankio grafikų buvo skaičiuoti dažnio šie dydžiai:

- slankio stiprinimo faktorius $Q$ rezonansiniame dažnyje;

- dinaminis ilinkio koeficientas $D D C$;

- maksimalus reliatyvusis stalviršio judesys MRTM.

Skaičiuojant priimtos tipinès perduodamumo koeficiento $T$ ir aplinkos virpesių intensyvumo lygi apibūdinančio spektrinio galios tankio $P S D$ vertès, t. y. $T=0,01$ ir $P S D=10^{-9}$.

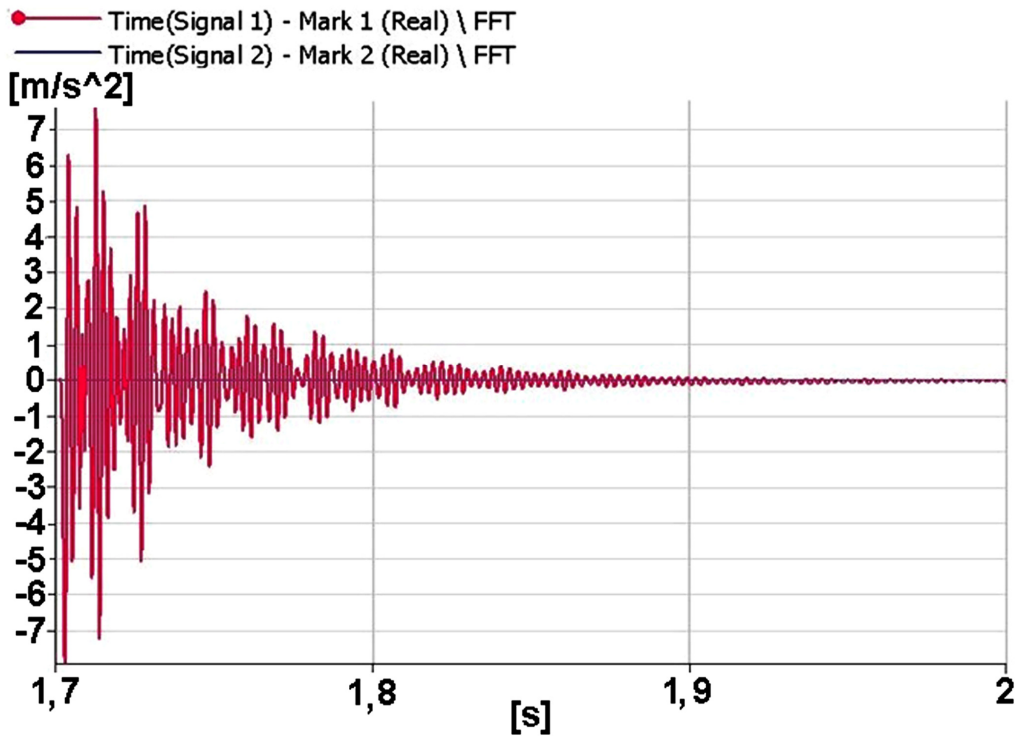

3.5 pav. Korinės konstrukcijos optinės plokštės virpesiu pagreičio amplitudès kitimo laike charakteristika 1 taške

Fig. 3.5. Characteristic of vibration acceleration amplitudes of an optical plate of the comb design in point 1 
Korinės konstrukcijos optinės plokštės virpesių pagreičio laiko charakteristikos pavyzdys pateiktas 3.5 pav. Iš kreivès galima daryti išvadą, kad beveik visos dedamosios greitai gesta, tačiau yra dvi virpesių dedamosios, kurios gesta palyginti lètai ir jų plakimasis aiškiai matomas.

Plakimosi periodas - apie $50 \mathrm{~ms}$, t. y. šių dedamujų dažnių skirtumas sudaro apie $20 \mathrm{~Hz}$. Śią išvadą patvirtina dinaminio slankio kreiveje (3.6 pav.) matomi du palyginti aukšti rezonansiniai pikai esant $199 \mathrm{~Hz}$ ir $220 \mathrm{~Hz}$ dažniams.

[mMIn]

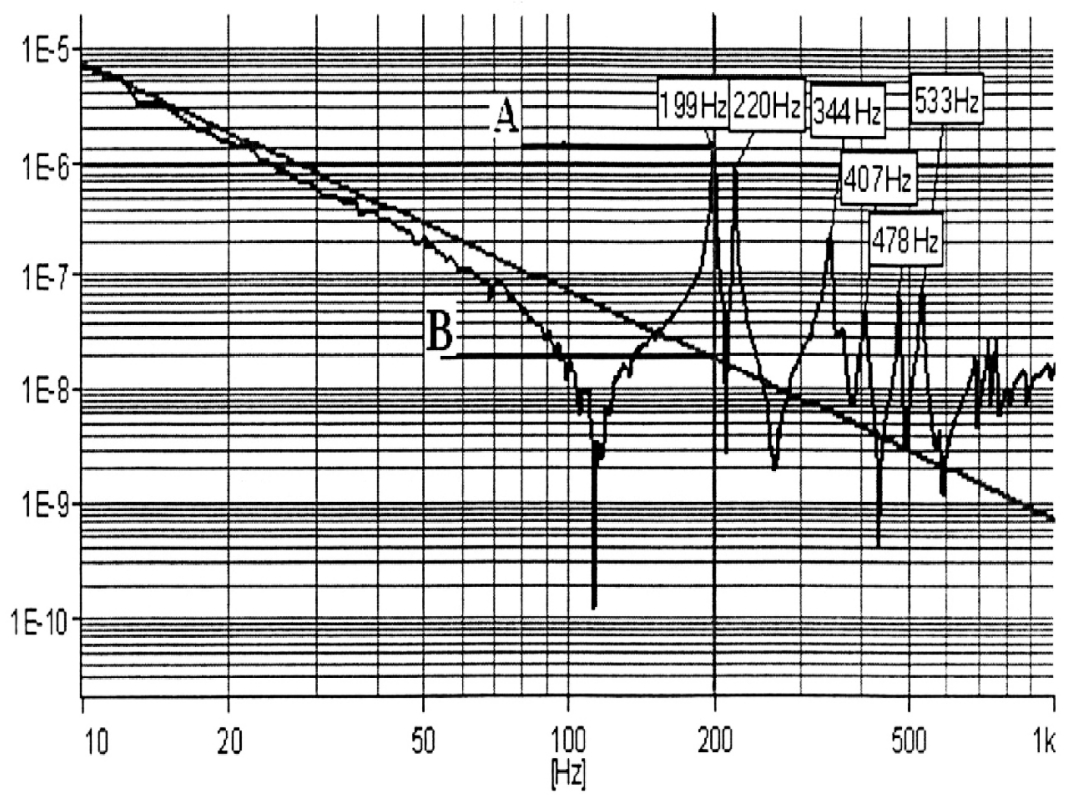

3.6 pav. Korinės konstrukcijos optinès plokštės dinaminio slankio kreivè ir rezonansiniai dažniai 1 taške

Fig. 3.6. Curve of dynamic displacement and resonance frequencies of an optical plate of the comb design in point 1

Pateikiame dinaminio illinkio koeficiento ir maksimalus reliatyviojo plokštès judesio (Maximum relative tabletop motion - MRTM) skaičiavimo pagal,„Newport“ ir „Melles Griot“" metodikas pavyzdžius.

Stalo 1 taško slankio stiprinimo faktorius $Q$ rezonansiniame dažnyje $f_{n}$ skaičiuojamas nubrèžus prie slankio kreivès (3.6 pav.) idealiai standaus kūno charakteristika, t. y. tiesę. Pradedant nuo žemiausiojo dažnio, slankio kreivè svyra žemyn be trūkių tol, kol optinis stalas yra standus ir joks santykinis judesys paviršiuje nepastebimas. Pirmojo rezonanso $(199 \mathrm{~Hz})$ zonoje skaičiuojamas santykis 


$$
Q=A / B,
$$

čia $A=1,24 ; B=0,0173 ; Q=71,7$.

Pagal formulę (3.7) paskaičiuojamas dinaminis ịlinkio koeficientas DİK $(D D C)$;

$$
D I K(D D C) \sqrt{Q / f_{n}^{3}}=0,00302=3,02-10^{-3} .
$$

Atvirkštinis dinaminiam įlinkio koeficientui dydis $\mathrm{DDC}^{-1}=331$. Maksimalus santykinis stalviršio 1 taško judesys skaičiuojamas pagal (2.36) formulę, čia $\mathrm{C}=0,623 \mathrm{~m} / \mathrm{s}^{2} ; P S D=10^{-9} \mathrm{~g}^{2} / \mathrm{Hz}$ (aplinkoje šalia kelio eismo); $T=0,01-$ izoliatoriaus perduodamumo charakteristika, imta pagal Melles Griot Super Damp ${ }^{\mathrm{TM}}$ kokybiškus izoliatorius.

Maksimalus santykinis stalviršio judesys pagal (2.36):

$$
M R T M=0,623 \cdot 0,01 \cdot \sqrt{\frac{71,68}{199^{3}} \cdot 10^{-9}}=0,59 \cdot 10^{-9} \mathrm{~m} .
$$

Tokia dimensija paaiškinama tuo, kad santykinis stalviršio taško judesys matuojamas veikiant $1 \mathrm{~m} / \mathrm{s}^{2}$ pagreičiui. Tiriamojo stalo 1 taške skaičiuoto maksimalaus reliatyviojo judesio $(M R T M)$ reikšmè yra $0,59 \mathrm{~nm}$.

3.1 lentelè. Optinès plokštės dinaminiai parametrai ịvairiuose matavimo taškuose

Table 3.1. Dynamic parameters of an optical plate in variable measurement points

\begin{tabular}{|l|l|l|l|l|}
\hline Matavimo taškas & \multicolumn{1}{|c|}{ Dažnis, $\mathbf{H z}$} & \multicolumn{1}{c|}{$\boldsymbol{Q}$} & \multicolumn{1}{c|}{ DDC } & \multicolumn{1}{c|}{ MRTM } \\
\hline 1 & 199 & 71,7 & 0,00302 & $0,59 \cdot 10^{-9}$ \\
\hline 11 & 199 & 72,2 & 0,00303 & $0,60 \cdot 10^{-9}$ \\
\hline 2 & 220 & 131,3 & 0,00351 & $0,69 \cdot 10^{-9}$ \\
\hline 3 & 370 & 23,5 & 0,00068 & $0,13 \cdot 10^{-9}$ \\
\hline 4 & 220 & 117,0 & 0,00331 & $0,65 \cdot 10^{-9}$ \\
\hline 5 & 220 & 114,3 & 0,00328 & $0,64 \cdot 10^{-9}$ \\
\hline 6 & 199 & 66,7 & 0,00291 & $0,57 \cdot 10^{-9}$ \\
\hline 7 & 220 & 85,0 & 0,00283 & $0,56 \cdot 10^{-9}$ \\
\hline 8 & 199 & 61,9 & 0,00280 & $0,55 \cdot 10^{-9}$ \\
\hline 9 & 220 & 106,3 & 0,00316 & $0,62 \cdot 10^{-9}$ \\
\hline 10 & 199 & 47,5 & 0,00246 & $0,48 \cdot 10^{-9}$ \\
\hline
\end{tabular}


Korinės konstrukcijos optinės plokštès tyrimų rezultatai pateikti 3.1 lentelèje. Matome, kad plokštès slankio stiprinimo faktorius $Q$ daugelyje matavimo tašku yra palyginti didelis (50-130), t. y. slopinimas yra mažas. Dinaminis įlinkio koeficientas $D D C$ blogiausiuose taškuose prie plokštès kampų ir centre yra 0,003-0,0033, o maksimalus reliatyvusis stalviršio judesys MRTM yra 0,5$0,7 \mathrm{~nm}$. Pirmieji penki rezonansiniai dažniai pateikti 3.3 lenteleje.

Platformos tyrimų rezultatai yra pateikti 3.2 lenteleje, o dinaminio slankio priklausomybès nuo dažnio grafikai -3.7 pav. Pirmieji penki rezonansiniai dažniai pateikti 3.3 lentelejje. Optinès plokštès ir platformos dinaminių parametrų vertès yra labai artimos.
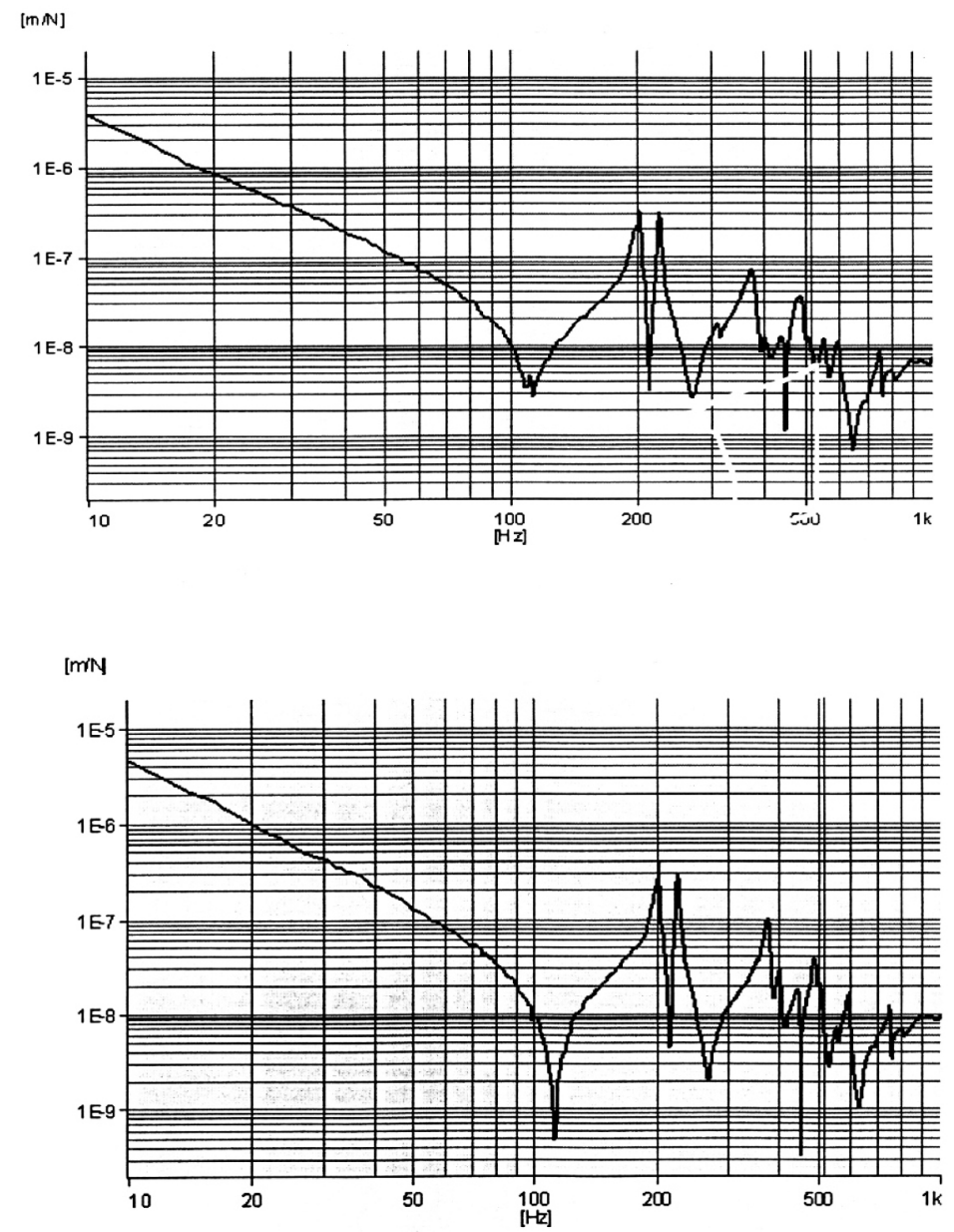

3.7 pav. Platformos slankio kreivès ir rezonansiniai dažniai

Fig. 3.7. Displacement curves and resonance frequencies of a platform 
Matome (3.7 pav.), kad platforma iki $80 \mathrm{~Hz}$ dažnio yra absoliučiai standus kūnas.

3.2 lentelè. Platformos dinaminiai parametrai įvairiuose matavimo taškuose

Table 3.2. Dynamic parameters of a platform at various measurement points

\begin{tabular}{|c|c|c|c|c|}
\hline Matavimo taškas & Dažnis, Hz & $\boldsymbol{Q}$ & DDC & MRTM \\
\hline 1 & 202 & 36,5 & 0,00210 & $0,41 \cdot 10^{-9}$ \\
\hline 11 & 202 & 30,8 & 0,00193 & $0,38 \cdot 10^{-9}$ \\
\hline 2 & 225 & 63,6 & 0,00236 & $0,47 \cdot 10^{-9}$ \\
\hline 3 & 488 & 43,8 & 0.00061 & $0,12 \cdot 10^{-9}$ \\
\hline 4 & 225 & 6,3 & 0,00074 & $0,17 \cdot 10^{-9}$ \\
\hline 5 & 225 & 50,9 & 0,00211 & $0,42 \cdot 10^{-9}$ \\
\hline 6 & 202 & 37,9 & 0,00214 & $0,42 \cdot 10^{-9}$ \\
\hline 7 & 225 & 76,0 & 0,00258 & $0,51 \cdot 10^{-9}$ \\
\hline 8 & 202 & 31,3 & 0,00195 & $0,38 \cdot 10^{-9}$ \\
\hline 9 & 225 & 58,0 & 0,00226 & $0,44 \cdot 10^{-9}$ \\
\hline 10 & 202 & 28,3 & 0,00185 & $0,36 \cdot 10^{-9}$ \\
\hline
\end{tabular}

3.3 lentelè. Optinės plokštės ir platformos rezonansiniai dažniai

Table 3.3. Resonance frequencies of an optical plate and platform

\begin{tabular}{|l|c|c|c|c|c|}
\hline \multirow{2}{*}{ Tyrimo objektas } & \multicolumn{5}{|c|}{ Rezonansiniai dažniai, Hz } \\
\cline { 2 - 6 } & 1 & 2 & 3 & 4 & 5 \\
\hline Optinè plokšte & 199 & 220 & 344 & 407 & 478 \\
\hline Platforma & 202 & 225 & 374 & 444 & 488 \\
\hline
\end{tabular}

Išanalizuota žinomų pasaulyje firmų „TMC“, „Melles Griot“, „Newport“ ir kitu gamintojų patirtis atliekant precizinių sistemų tyrimus ir bandymus, atlikta rezultatų lyginamoji analizè. 
Pateikiame firmos „Newport“ RPR ir RT serijos optinių stalu $(1200 \times 2400 \times 305 \mathrm{~mm})$ bei „Melles Griot" firmos optinio stalo Stable Top ${ }^{\mathrm{TM}}$ (matmenys $1200 \times 2400$, storis nuo 210 iki $310 \mathrm{~mm}$ ) dinamines charakteristikas:

Maksimalus dinaminis ilinkio koeficientas $(D D C)$ :

RPR serijos optiniam stalui

RT serijos optiniam stalui

Stable Top ${ }^{\mathrm{TM}} 250$ optiniam stalui

$$
\begin{aligned}
& <2,0 \cdot 10^{-3} \\
& <2,8 \cdot 10^{-3}
\end{aligned}
$$

Maksimalus reliatyvusis plokštès judejimas (MRTM):

RPR serijos optiniam stalui*

RT serijos optiniam stalui*

$$
\begin{aligned}
& <3,0 \cdot 10^{-7} \\
& <4,6 \cdot 10^{-7}
\end{aligned}
$$

Stable Top ${ }^{\mathrm{TM}} 250$ optiniam stalui $<0,18 \mathrm{~nm}$

Matome, kad firmoje UAB „Standa“ gaminami optiniai stalai atitinka geriausių pasaulyje gamintojų parametrus.

\subsection{Optinių stalų izoliacinių atramų dinaminių charakteristiku tyrimai ir rezultatai}

Tyrimo stendo schema parodyta 3.8 paveiksle.

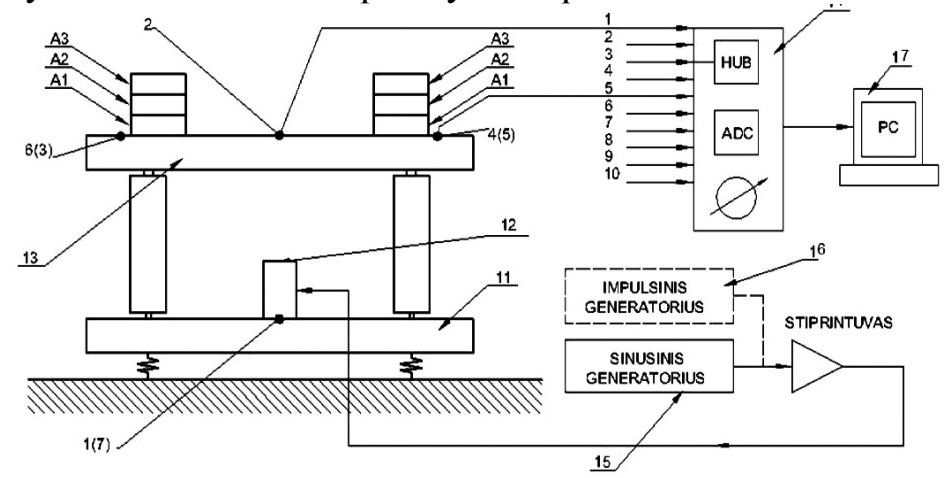

3.8 pav. Optinio stalo izoliacinių atramų dinaminiu charakteristikų tyrimo schema: 1-10 - virpesiu jutikliai; 11 - platforma (pagrindas); 12 - vibratorius; 13 - optinis stalas su bandomosiomis virpesių izoliacinemis atramomis; 14 - analizatorius 3660-D; 15 - sinusinis generatorius; 16 - impulsinis generatorius; 17 - kompiuteris; A1-A3 optinio stalo apkrovos. Virpesių žadinimo kryptys: $\mathrm{Z}$ - vertikali; Y - horizontali skersinè;, $X$ - horizontali išilginè

Fig. 3.8. Research scheme of dynamic characteristics of isolation supports of an optical tabale: 1-10 - vibration transducers; 11 - platform; 12 - vibrator; 13 - optical tabale with an experimental vibration isolation supports; 14 - analysator 3660-D; 15 - sinusoidal generator; 16 - impulse generator; 17 - computer; A1-A3 - loads of an optical table. Directions of vibration excitation: $\mathrm{Z}$ - vertical, $\mathrm{Y}$ - horizontal transverse; $\mathrm{X}$ - horizontal longitudinal 
Optinio stalo (3.1 ir 3.8 pav.) virpesių izoliavimo atramų tyrimo rezultatai, kai buvo žadinama harmoniniais virpesiais, impulsiniais ir baltuoju triukšmu, tipiniai slopinimai parodyti 3.9 pav., a, b, c, d, e, f, o perduodamumo kreivè -3.10 pav.

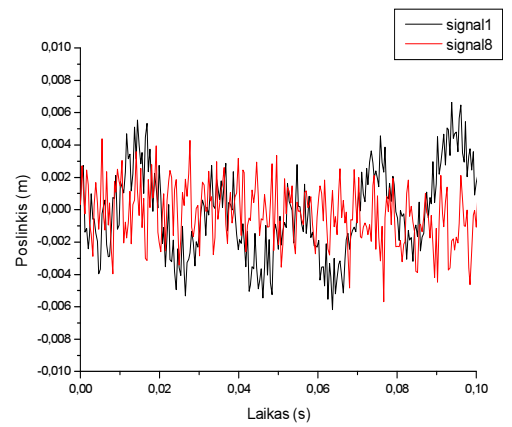

a

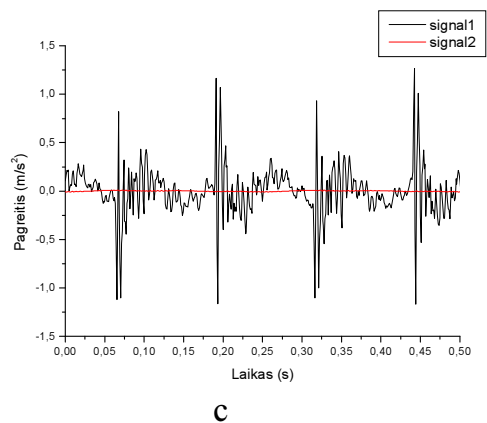

C

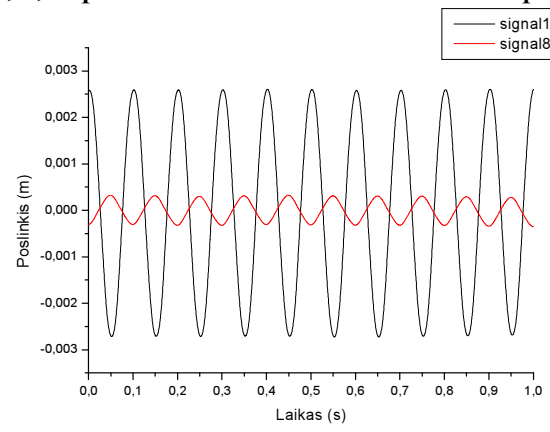

b

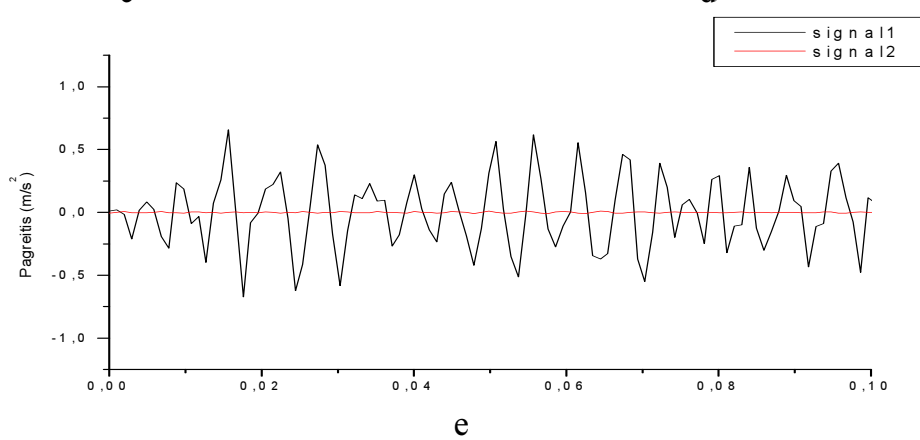

3.9 pav. Virpesių izoliavimo atramų slopinimo charakteristikos (juodas signalas - platformos, raudonas - optinio stalo): $\mathrm{a}-2 \mathrm{~Hz}$ harmoninis žadinimo dažnis; $\mathrm{b}-10 \mathrm{~Hz}$ harmoninis žadinimo dažnis; $\mathrm{c}-4 \mathrm{~Hz}$ impulsinis žadinimas; $d-10 \mathrm{~Hz}$ impulsinis žadinimas; e - žadinimas baltuoju triukšmu

Fig. 3.9. Damping characteristics of vibration isolation supports (black signal - of platform, red - of optical table): $\mathrm{a}-2 \mathrm{~Hz}$ harmonic excitation frequency; $\mathrm{b}-10 \mathrm{~Hz}$ harmonic excitation frequency; c $-4 \mathrm{~Hz}$ impulse excitation; $\mathrm{d}-10 \mathrm{hz}$ impulse excitation; e excitation by white noise 
Kai yra harmoninis žadinimas esant $2 \mathrm{~Hz}$, virpesiai nėra izoliuojami, izoliavimas prasideda nuo $4 \mathrm{~Hz}$. Taigi dažniams iki $4 \mathrm{~Hz}$ optiniai stalai nèra efektyvūs.

Optinio stalo izoliacinių atramų perduodamumas buvo tiriamas pagal 3.1 skyriuje aprašytą metodiką vertikalia, horizontalia skersine ir horizontalia išilgine kryptimis. Toliau pateikiami svarbiausi virpesių izoliavimo atramų tyrimų rezultatai $1-50 \mathrm{~Hz}$ dažnių ruože, apkrovus skirtingų dydžių apkrovomis (perduodamumo priklausomybès nuo dažnio kreivès $T_{v}, T_{s}, T_{i}$, atitinkami rezonansiniai dažniai $f_{v r}, \mathrm{f}_{1 \mathrm{sr}}, f_{2 s r}, f_{\text {lir }}, f_{2 i r}$ ir perduodamumo koeficientų vertés esant rezonansiniams $5 \mathrm{~Hz}$ ir $10 \mathrm{~Hz}$ dažniams).

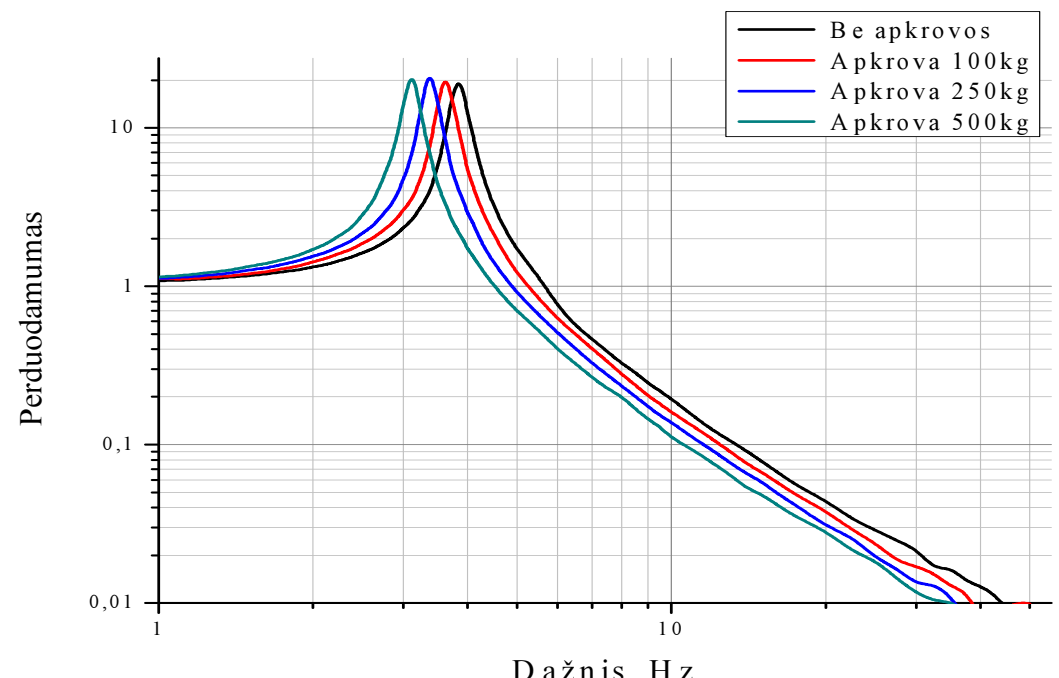

3.10 pav. Virpesių izoliavimo atramų perduodamumo vertikalia kryptimi $T_{z}$ priklausomybė nuo dažnio ir apkrovos

Fig. 3.10. Dependence of transmissibility of vibration isolation supports in vertical direction $\mathrm{T}_{\mathrm{z}}$ on frequency and load

Perduodamumo vertikalia kryptimi grafikuose matomas vienas palyginti mažai nuslopintas rezonansas. Tai rodo, kad virpesių izoliavimo atramos kartu su apkrova sudaro elementarią vienos masès virpamają sistemą. Rezonanso dažnis mažèja didinant virpesių izoliavimo atramų apkrovą. Dažniui didejjant aukščiau rezonanso, perduodamumas tolygiai mažeja ir dažniuose nuo $50 \mathrm{~Hz}$ yra mažiau kaip 0,01 .

Tiriant horizontalia kryptimi nustatyta, kad šia kryptimi virpesių izoliavimo atramos kartu su apkrova yra sudètinga sistema, turinti keletą rezonansų. Tai paaiškinama tuo, kad žadinimas veikia ne per sistemos masès centrą, o žemiau. 
Dèl to atsiranda sukimo momentas ir sužadinami ne tik išilginiai apkrovos virpesiai, bet ir sukamieji. Be to, virpesiu izoliavimo atramų korpusas horizontalia kryptimi yra nedidelio standumo (kiekvienos kojos šis standumas yra skirtingas) ir rezonuoja dažnių ruože $20-50 \mathrm{~Hz}$. Tai savo ruožtu pablogina perduodamumo charakteristiką.

3.4 lentelè. Virpesių izoliavimo atramų savujų (rezonansinių) dažnių $f_{v r}$ (Natural Frequency) ir perduodamumo koeficiento vertikalia kryptimi priklausomybè nuo apkrovos, esant $5 \mathrm{~Hz}$ ir $10 \mathrm{~Hz}$ rezonanso dažniams

Table 3.4. Dependence of self (resonance) frequencies $f_{v r}$ and transmissibility coefficient of vibration isolation supports in vertical direction on load at resonance, $5 \mathrm{~Hz}$ and $10 \mathrm{~Hz}$ frequency

\begin{tabular}{|c|c|c|c|c|}
\hline \multirow{2}{*}{$\begin{array}{l}\text { Rezonansinis } \\
\text { dažnis }\end{array}$} & \multicolumn{3}{|c|}{ Perdodadumo koeficientas $T_{v}$ dažniuose } & \multirow{2}{*}{$\begin{array}{c}\text { Papildoma } \\
\text { apkrova }\end{array}$} \\
\hline & rezonanso & $5 \mathrm{~Hz}$ & $10 \mathrm{~Hz}$ & \\
\hline$f_{v r}, \mathrm{~Hz}$ & $T_{v r}$ & $T_{v 5 \mathrm{~Hz}}$ & $T_{v 10 \mathrm{~Hz}}$ & $\mathrm{~kg}$ \\
\hline 3,875 & 21,1 & 1,70 & 0,19 & Be apkrovos \\
\hline 3,625 & 22,7 & 1,20 & 0,16 & $100 \mathrm{~kg}$ \\
\hline 3,375 & 24,9 & 0,91 & 0,14 & $250 \mathrm{~kg}$ \\
\hline 3,125 & 25,2 & 0,70 & 0,11 & $500 \mathrm{~kg}$ \\
\hline
\end{tabular}

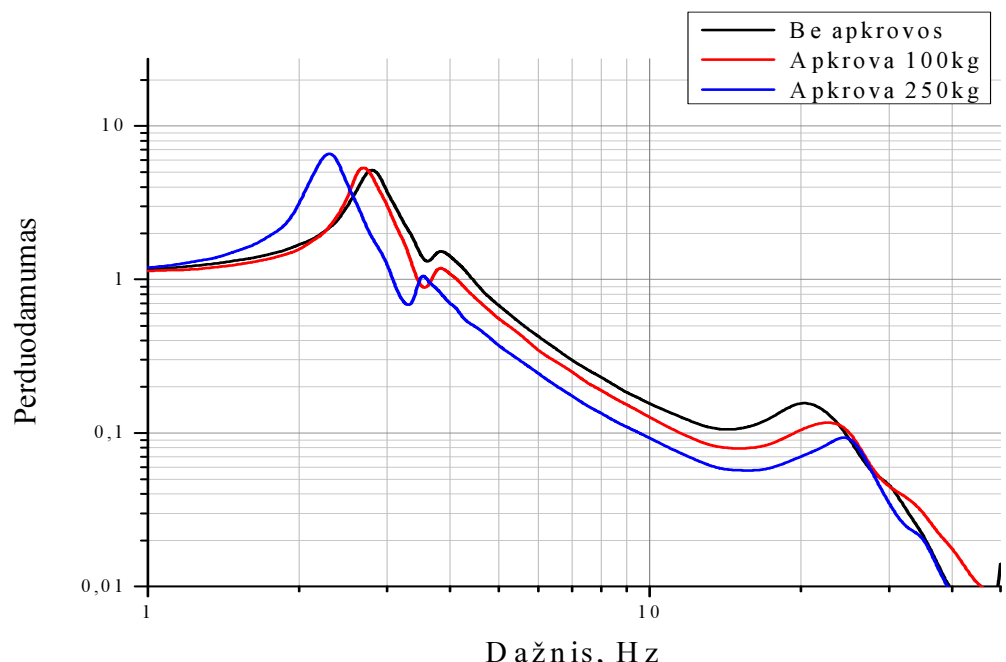

3.11 pav. Virpesių izoliacinių atramų perduodamumo horizontalia išilgine kryptimi $T_{i}$ priklausomybė nuo dažnio ir apkrovos

Fig. 3.11. Dependence of transmissibility of vibration isolation supports in horizontal direction $T_{i}$ on frequency and load 
3.11 pav. pateikta virpesių izoliavimo atramų perduodamumo horizontalia išilgine kryptimi $T_{i}$ priklausomybe nuo dažnio ir apkrovos. Grafike matomas pirmasis $(2-3 \mathrm{~Hz})$ ruože yra slenkamujų svyravimų rezonansas. Antrasis rezonansas $(3,5-4 \mathrm{~Hz})$ yra sukamuju (apie apkrovos masės centra) svyravimų rezonansas. Tikètina, kad perduodamumo kreivès nemonotoniškumas aukščiau $20 \mathrm{~Hz}$ yra dèl atramų korpusų rezonansų.

3.5 lentelè. Virpesių izoliacinių atramų savujų (rezonansinių) dažnių $f_{\text {ir }}$ (Natural Frequency) ir perduodamumo koeficiento horizontalia išilgine kryptimi priklausomybè nuo apkrovos esant $5 \mathrm{~Hz}$ ir $10 \mathrm{~Hz}$ rezonanso dažniams

Table 3.5. Dependence of self (resonance) frequencies $f_{i r}$ and transmissibility coefficient of vibration isolation supports in horizontal longitudinal direction on load at resonance, $5 \mathrm{~Hz}$ and $10 \mathrm{~Hz}$ frequency

\begin{tabular}{|c|c|c|c|c|c|c|}
\hline \multicolumn{2}{|c|}{ Rezonansiniai dažniai } & \multicolumn{4}{|c|}{$\begin{array}{c}\text { Perduodamumo koeficientas esant } \boldsymbol{T}_{\boldsymbol{i}} \\
\text { dažniams }\end{array}$} \\
\cline { 1 - 4 } pirmasis & antrasis & \multicolumn{2}{|c|}{ rezonanso } & $\mathbf{5 ~ H z}$ & $\mathbf{1 0 ~ H z}$ & $\begin{array}{c}\text { Papkoma } \\
\text { apkova }\end{array}$ \\
\hline$f_{i 1 r}, \mathrm{~Hz}$ & $f_{i 2 r}, \mathrm{~Hz}$ & $T_{i 1 r}$ & $T_{i 2 r}$ & $T_{i 5 \mathrm{~Hz}}$ & $T_{i 10 \mathrm{~Hz}}$ & $\mathrm{~kg}$ \\
\hline 2,750 & 3,875 & 5,34 & 1,54 & 0,68 & 0,15 & Be apkrovos \\
\hline 2,625 & 3,875 & 5,48 & 1,19 & 0,55 & 0,13 & $100 \mathrm{~kg}$ \\
\hline 2,250 & 3,500 & 7,24 & 1,16 & 0,37 & 0,093 & $250 \mathrm{~kg}$ \\
\hline
\end{tabular}

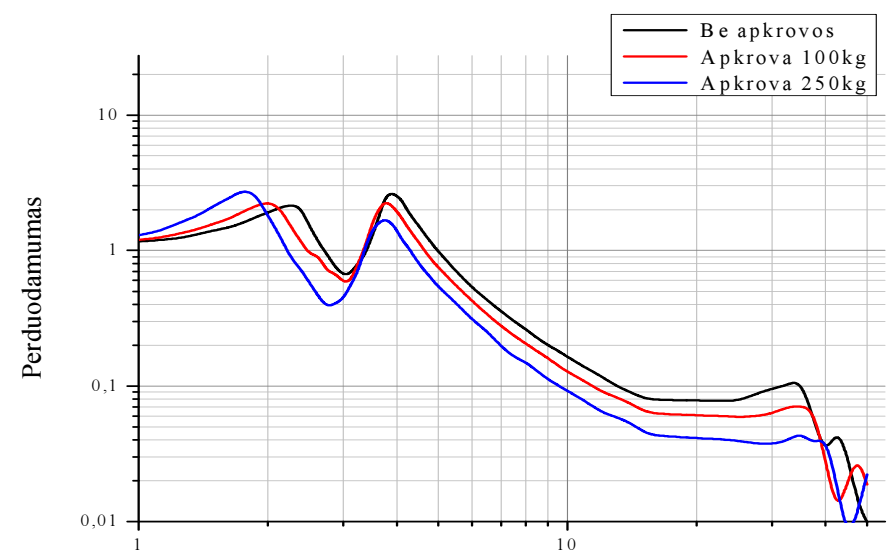

$\mathrm{D}$ ažn is, $\mathrm{Hz}$

3.12 pav. Virpesių izoliacinių atramų perduodamumo horizontalia skersine kryptimi $T_{s}$ priklausomybè nuo dažnio ir apkrovos

Fig. 3.12. Dependence of transmissibility of vibration isolation supports in horizontal traverse direction $T_{s}$ on frequency and load 
3.12 pav. pateikta virpesių izoliacinių atramų perduodamumo horizontalia skersine kryptimi $T_{s}$ priklausomybè nuo dažnio ir apkrovos. Šiuo atveju antrasis sukamujų virpesių rezonansas yra kur kas ryškesnis nei horizontalaus išilginio žadinimo atveju. Taip pat labai aiškiai matomi rezonansai $25-50 \mathrm{~Hz}$ dažnių ruože.

3.6 lentelè. Virpesių izoliacinių atramų savujų (rezonansinių) dažnių $f_{s r}$ (Natural Frequency) ir perduodamumo koeficiento horizontalia skersine kryptimi priklausomybè nuo apkrovos esant $5 \mathrm{~Hz}$ ir $10 \mathrm{~Hz}$ rezonanso dažniams

Table 3.6. Dependence of self (resonance) frequencies $f_{s r}$ and transmissibility coefficient of vibration isolation supports in horizontal traverse direction on load at resonance, $5 \mathrm{~Hz}$ and $10 \mathrm{~Hz}$ frequency

\begin{tabular}{|c|c|c|c|c|c|c|}
\hline \multicolumn{2}{|c|}{ Rezonansiniai dažniai } & \multicolumn{4}{|c|}{ Perduodamumo koeficientas esant $\boldsymbol{T}_{\boldsymbol{s}}$ daž- } & \multirow{2}{*}{$\begin{array}{c}\text { Papildoma } \\
\text { niams }\end{array}$} \\
\cline { 1 - 5 } pirmasis & antrasis & \multicolumn{2}{|c|}{ rezonanso } & $5 \mathrm{~Hz}$ & $10 \mathrm{~Hz}$ & apkova \\
\hline$f_{s 1 r}, \mathrm{~Hz}$ & $f_{s 2 r,} \mathrm{~Hz}$ & $T_{s 1 r}$ & $T_{s 2 r}$ & $T_{s 5 \mathrm{~Hz}}$ & $T_{s 10 \mathrm{~Hz}}$ & $\mathrm{~kg}$ \\
\hline 2,250 & 3,875 & 2,17 & 2,66 & 0,98 & 0,16 & Be apkrovos \\
\hline 2,000 & 3,750 & 2,28 & 2,30 & 0,75 & 0,13 & $100 \mathrm{~kg}$ \\
\hline 1,750 & 3,750 & 2,80 & 1,71 & 0,54 & 0,092 & $250 \mathrm{~kg}$ \\
\hline
\end{tabular}

Laboratorinių optinių stalų dinamika. Optiniai stalai su matavimo priemonemis ir femtosekundiniu lazeriu parodyti 3.13 pav.

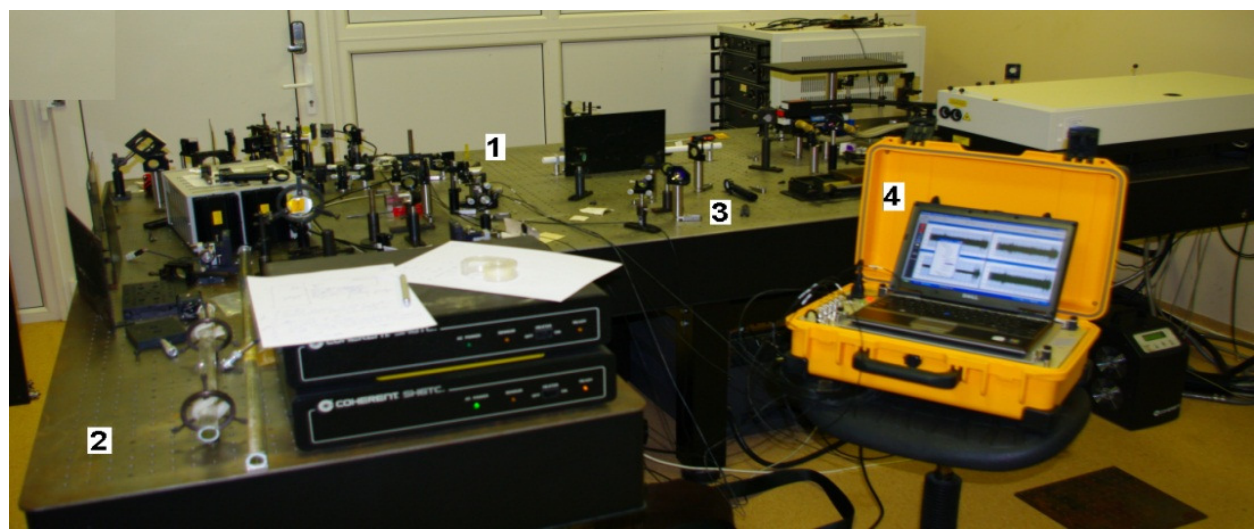

3.13 pav. Matavimo priemonių išsidėstymas ant dviejų optinių tarpusavyje sujungtų stalų

Fig. 3.13. Location of measurement means on two optical tables, which are interconnected 
Ant stalo 3 (3.13 pav.) buvo pritvirtinta orientavimo kaladèle, ant kurios trimis kryptimis išdėstyti trys akcelerometrai (3.14 pav. pažymètas 1). 3.13 pav. akcelerometrų tvirtinimo vieta pažymèta 1 . Ant stalo 2 (3.13 pav.) pritvirtinta kita orientavimo kaladèlè, ant kurios dviem kryptimis išdèstyti du akcelerometrai (3.14 pav. pažymètas 2). 3.13 pav. parodyta kilnojamoji matavimo rezultatu apdorojimo iranga 4 „Machine Diagnostics Toolbox Type $9727^{\prime}$ su kompiuteriu DELL.
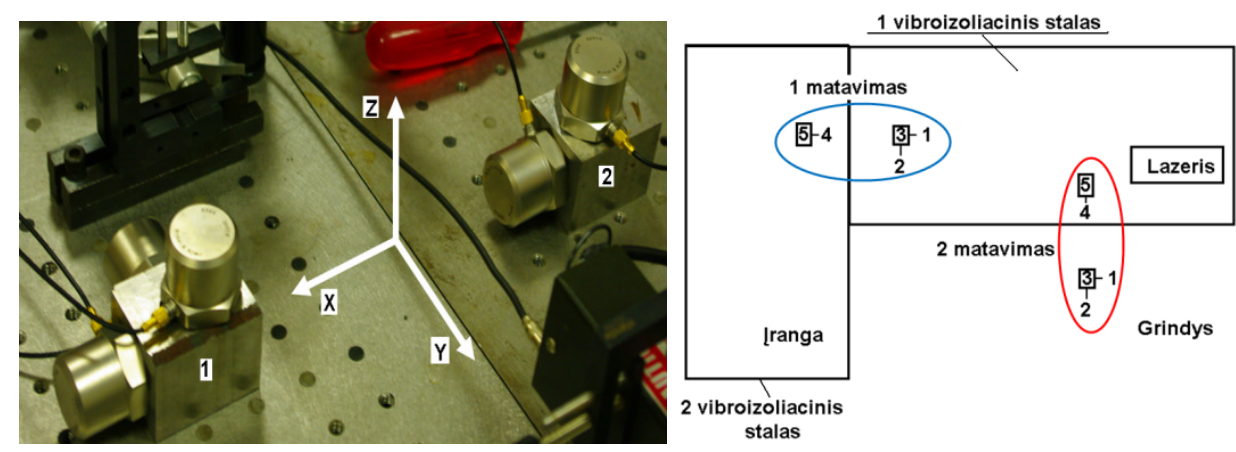

3.14 pav. Akcelerometrų 8344 išsidèstymas ant optinių stalų

Fig. 3.14. Location of accelerometers 8344 on optical tables

3.14 pav. pavaizduota virpesiu matavimo stendo schema, kurioje pavaizduotas dviejų matavimų vieta ir keitlių išsidèstymas.

Matavimai buvo atliekami, kai visi įrenginiai buvo išjungti, jjungtas vandens siurblys, ventiliatorius, maitinimo blokas, oro pūtimo sistema, kompiuteris. Buvo matuojami pagreitis ir poslinkis. Vienu metu matuot 5 taškuose. Matavimo rezultatai buvo apdorojami programiniu paketu „Pulse“. Žymejjimų grafikuose reikšmès: $m=10^{-3}, u=10^{-6}, n=10^{-9}$.

Toliau pateikti penkių taškų (3.15 pav. 1, 2, 3 grindų taškai ir 4, 5 optinio stalo taškai) pagreičio ir poslinkio amplitudžių virpesių ir spektrinio tankio grafikai. 


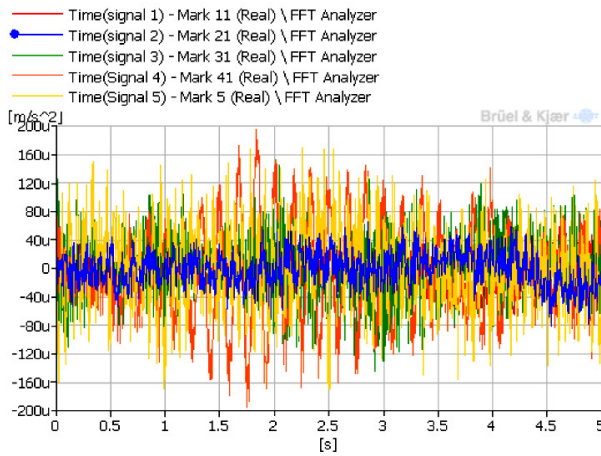

a)

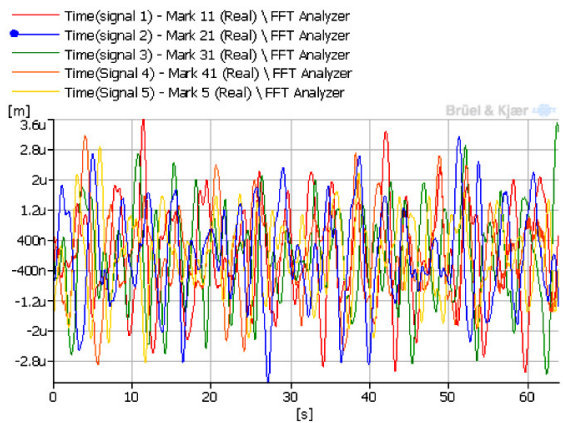

c)

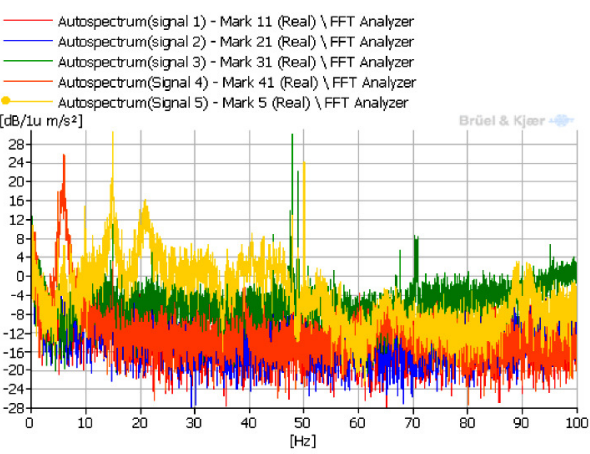

b)

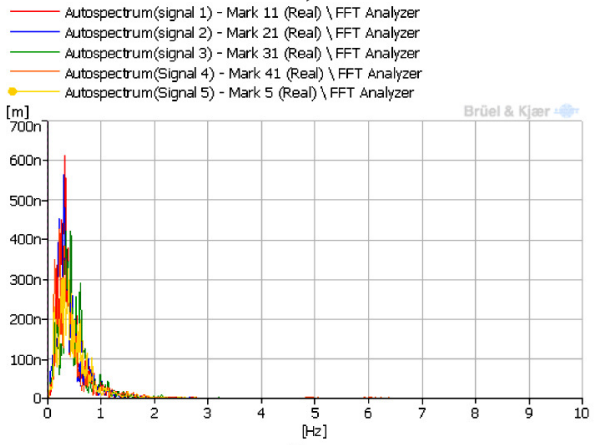

d)

3.15 pav. Pagreičio amplitudžių laikiniai grafikai (a), spektrinio tankio grafikai (b), poslinkio amplitudžių grafikai (c) ir spektrinio tankio grafikai (d)

Fig. 3.15. Time graphics of acceleration amplitudes (a) and graphics of spectral density (b) and graphics of displacement amplitudes (c) and graphics of spectral density (d)

Iš pateiktu grafikų matyti, kad laboratorijos irenginių ir aplinkos sukeliami virpesiai yra atsitiktinio pobūdžio, kuriu poslinkio amplitudes išilgine, skersine ir vertikalia kryptimis svyruoja nuo $2,4 \mu \mathrm{m}$ iki 3,2 $\mu \mathrm{m}$, pagreičio amplitudes atitinkamai nuo $50 \mu \mathrm{m} / \mathrm{s}^{2}$ iki $100 \mu \mathrm{m} / \mathrm{s}^{2}$. Poslinkio spektrinio tankio amplitudès $0,5 \mathrm{~Hz}$ dažnyje siekia $0,42 \mu \mathrm{m}$. Pagreičiu spektrinis tankis rodo, kad visame dažnių ruože amplitudes siekia $-20 \mathrm{~dB}$ ir tik nuo 5 iki $50 \mathrm{~Hz}$ pagreičio amplitudès vertikalia kryptimi svyruoja nuo 4 iki $25 \mathrm{~dB}$. Taigi esant tokio žemo dažnio virpesiams, optiniai stalai filtruoja tik aukštesnio dažnio pagreičių amplitudes, o žemujų dažnių virpesiams izoliuoti reikalingos naujos kartos sistemos. 


\subsection{Trečiojo skyriaus išvados}

1. Pasiūlyta ir aprobuota korinès konstrukcijos plokščių dinaminių parametrų nustatymo metodika.

2. Pasiūlyta ir aprobuota virpesių izoliavimo atramų tyrimų ir dinaminių parametrų nustatymo metodika.

3. Suprojektuota ir išbandyta speciali virpesių sužadinimo bandymų iranga, leidžianti nustatyti tiriamujų objektų dinamines charakteristikas visomis trimis kryptimis.

4. Nustatyti šie korinès konstrukcijos optinių plokščių dinaminiai parametrai:

- virpesių pagreičio laiko charakteristika;

- dinaminis slankis 10-1000 Hz dažnių ruože (Compliance);

- pirmieji rezonansiniai dažniai;

- dinaminis įlinkio koeficientas DİK (Dynamic Deflection Coefficient);

- maksimalus reliatyvusis plokštès judejimas (Maximum Relative Tabletop Motion).

5. Nustatyti šie pneumatinių virpesių izoliatorių dinaminiai parametrai:

- virpesiu perduodamumo vertikalia, horizontalia skersine ir horizontalia išilgine kryptimi charakteristikos (L50) Hz dažnių juostoje;

- rezonansinis dažnis (vertikalia, horizontalia skersine ir horizontalia išilgine kryptimi);

- slopinimo efektyvumas esant $5 \mathrm{~Hz}$ ir $10 \mathrm{~Hz}$ dažniams. 


\section{4}

\section{Mechaninių virpesių izoliavimo sistemų eksperimentiniai tyrimai}

Skyriuje nagrinejama autoriaus sukurtu originalių mechaninės koncepcijos pasyviujų žemojo dažnio virpesių izoliavimo sistemų dinaminių charakteristikų eksperimentiniai tyrimai ir pateiktai izoliavimo rezultatai. Ištirtos sudètinès virpesių izoliavimo sistemos dinaminès charakteristikos ir parodyta jos ribotos virpesiu izoliavimo galimybès. Nustatyta absoliučių virpesių matavimo rezultatų neapibrèžtis. Šio skyriaus medžiaga paskelbta autoriaus publikacijose (Kilikevičius et al. 2010; Jurevičius et al. 2011; Berba 2012)

\subsection{Kvazinulinio (neigiamo) standžio virpesių izoliavimo sistemos tyrimas}

Kvazinulinio standžio virpesių izoliavimo sistemos eksperimentinis stendas parodytas 4.1 pav. Tyrimo metodika analogiška optinių stalų tyrimo metodikai aprašytai 3 skyriuje su naudojamomis tyrimo priemonemis. 


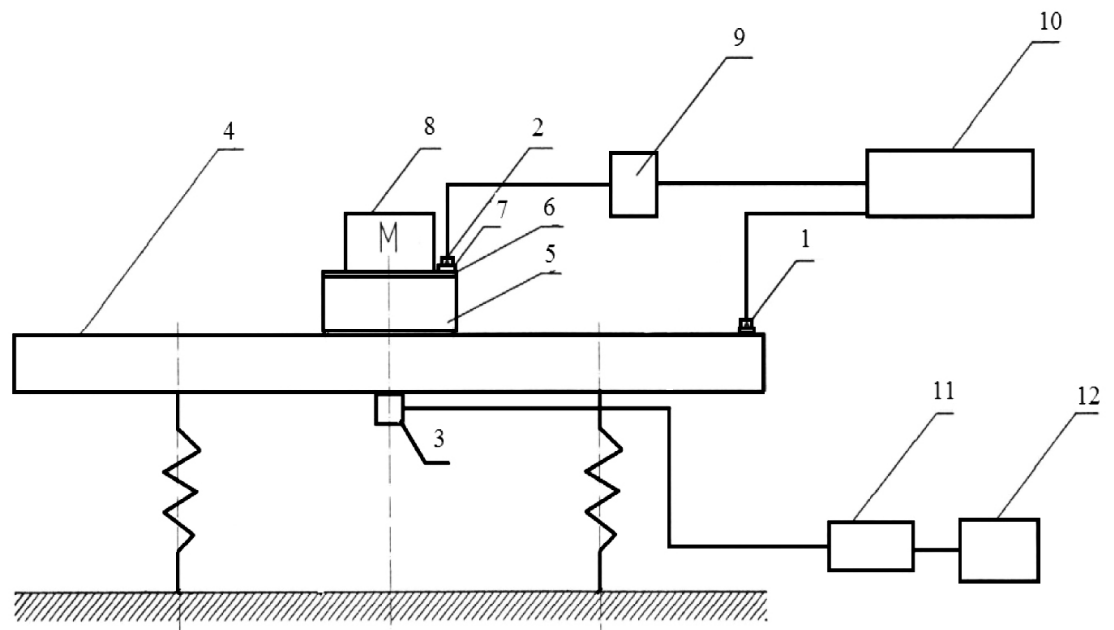

4.1 pav. Virpesių žadinimas naudojant vibratorių: 1 - seisminis akcelerometras 8318 ; 2 - seisminis akcelerometras 8306 ; 3 - vibratorius ; 4 - virpanti platforma; 5 - kvazinulinio (neigiamo) standžio virpesių izoliavimo sistema; 6 -tvirtinimo plokštė; 7 - orientavimo kaladèlè; 8 - masè - $200 \mathrm{~kg} ; 9$ - vibrometras $2511 ; 10$ - kilnojamoji matavimo rezultatu apdorojimo iranga „Machine Diagnostics Toolbox Type 9727“ su kompiuteriu DELL; 11 - stiprintuvas 2706; 12 - virpesiu generatorius 1027

Fig. 4.1. Excitation of vibrations by use of vibrator: 1 - seismic accelerometer 8318; 2 - seismic accelerometer 8306; 3 - vibrator; 4 - vibrating platform; 5 - vibration isolation system of quasi- zero (negative) stiffness; 6 - fixing plate; 7 - orienting log; 8 - mass $200 \mathrm{~kg} ; 9$ - vibrometer $2511 ; 10$ - movable equipment of result handling "Machine Diagnostics Toolbox Type 9727" with a computer DELL; 11 - amplyfier 2706; 12 - vibration generator 1027

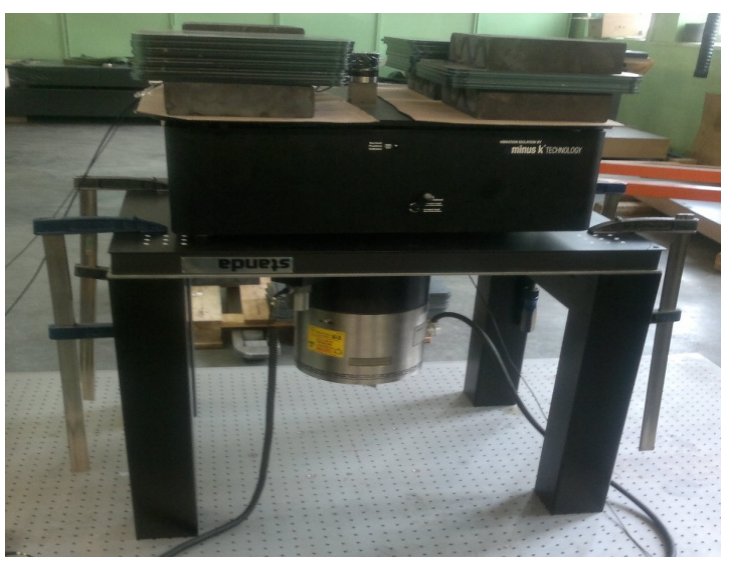

4.2 pav. Stendo nuotrauka

Fig. 4.2. Photo of a stand 


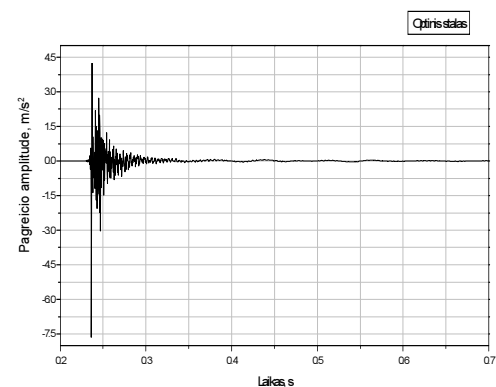

a

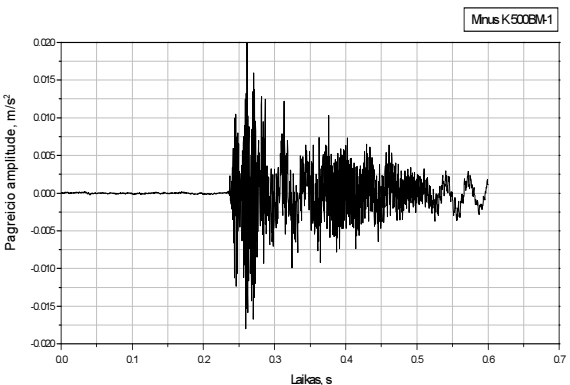

$\mathrm{b}$

4.3 pav. Išplèsti impulsiniai žadinimo signalai ant platformos (a) ir ant kvazinulinio standžio sistemos (b)

Fig. 4.3. Expanded impulce excitation signals on platform (a) and on a system of quasi-zero stiffness

4.3 pav., a, pateiktame išplèstame žadinimo signalo grafike didžiausia pagreičio amplitudès reikšmė laiko momentu $0,236 \mathrm{~s}$ lygi minus $7,64 \mathrm{~m} / \mathrm{s}^{2}$, o 4.3 pav., b, tuo pačiu laiko momentu nuslopinto signalo pagreičio amplitudès reikšmè lygi minus $0,00031 \mathrm{~m} / \mathrm{s}^{2}$.

Laikinès charakteristikos vaizdžiai rodo dinamines sistemos savybes natūralioje laiko $t$ srityje (4.4 pav., a, b, c, d, e, f, g, h, k).

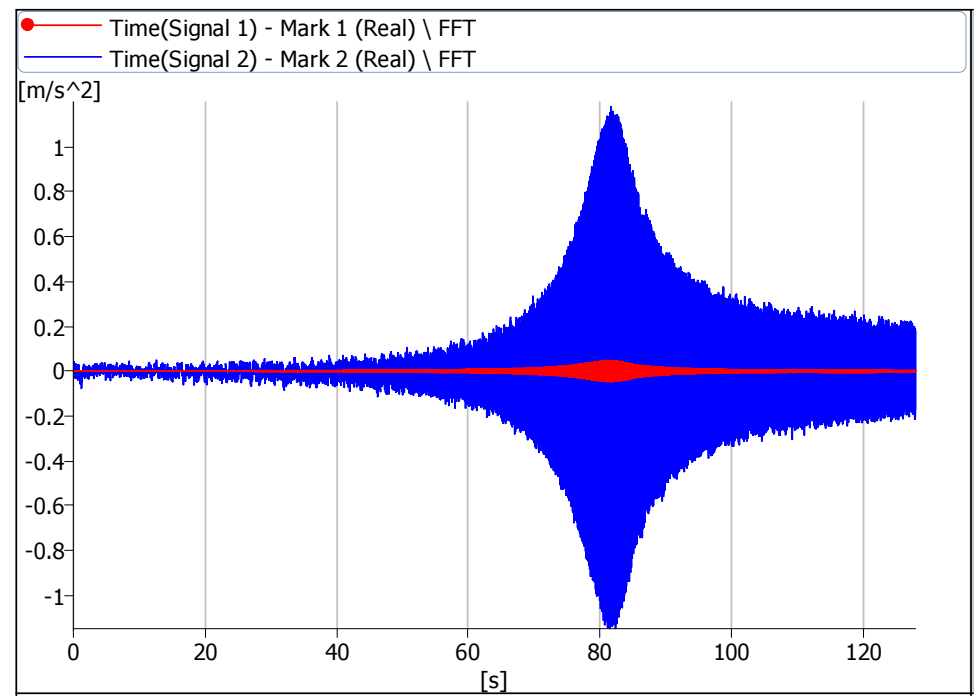




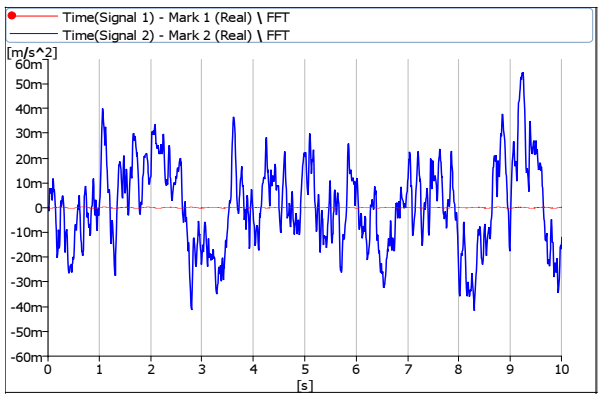

b

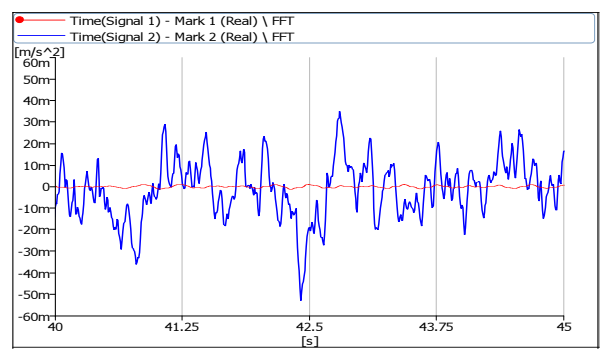

d

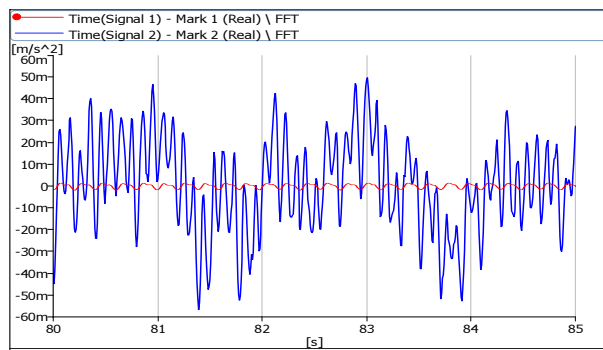

$\mathrm{f}$

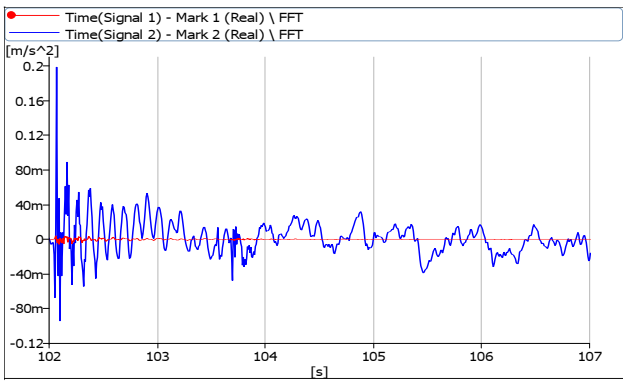

$\mathrm{h}$

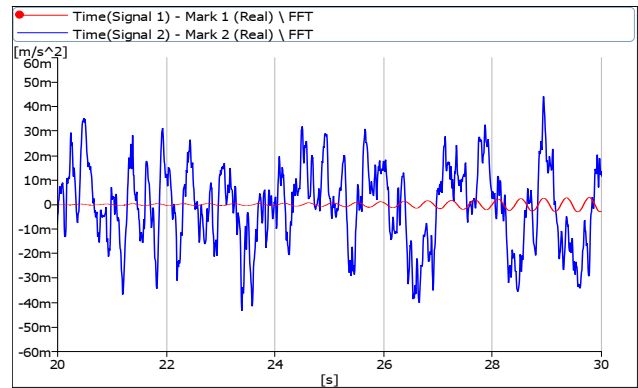

$\mathrm{C}$

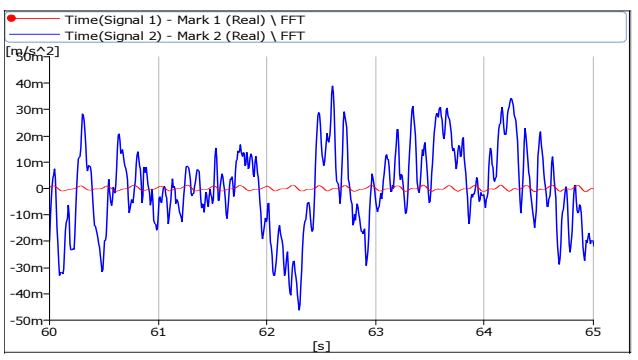

$\mathrm{e}$

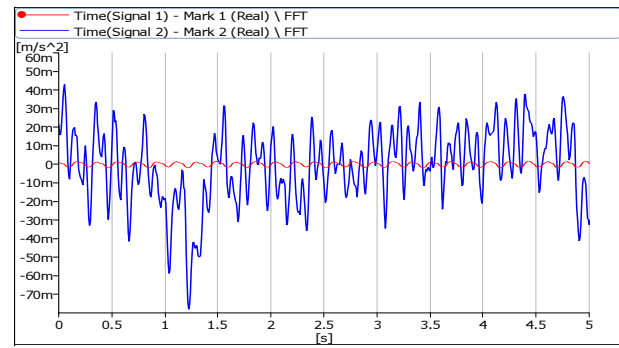

$\mathrm{g}$

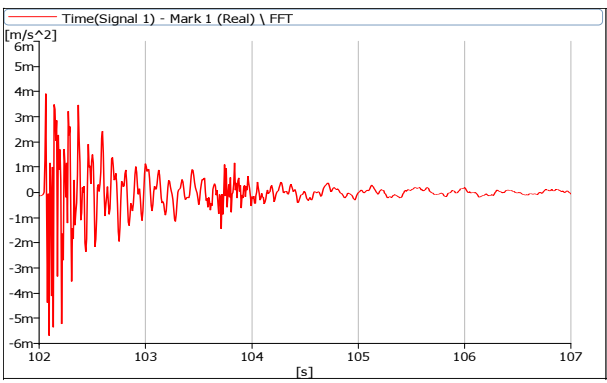

$\mathrm{k}$ 


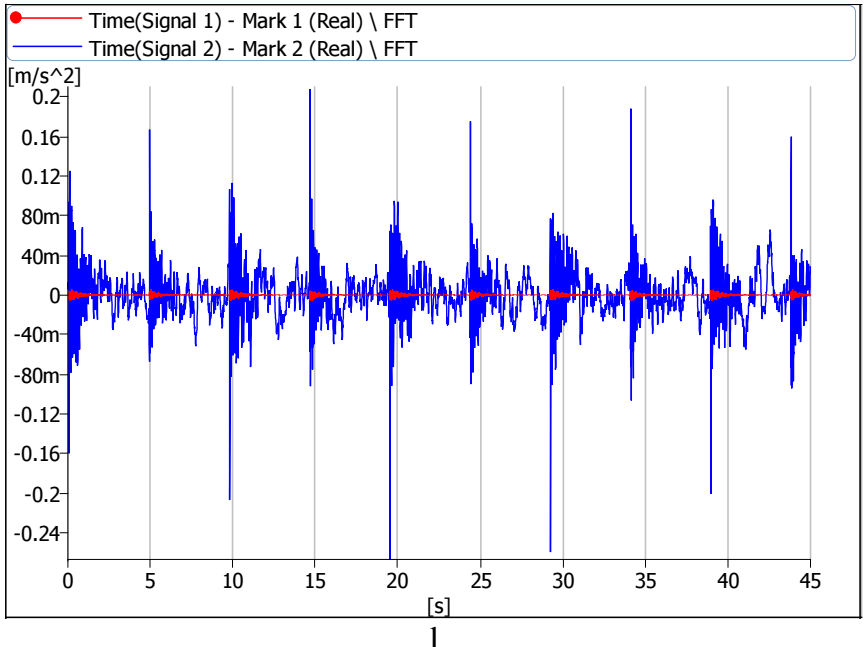

4.4 pav. Kvazinulinio (neigiamo) standžio virpesių izoliavimas (mèlynas signalas - platformos, raudonas - tiriamos sistemos):

$\mathrm{a}, \mathrm{b}, \mathrm{c}, \mathrm{d}, \mathrm{e}, \mathrm{f}, \mathrm{g}$ - harmoninis žadinimas; $\mathrm{h}, \mathrm{k}, \mathrm{l}$ - impulsinis žadinimas

Fig. 4.4. Isolation of vibrations of quasi-zero (negative) stiffness (blue signal - platform, red signal - of a researched system): a, b, c, d, e, f, g-harmonic excitation; $\mathrm{h}, \mathrm{k}, \mathrm{l}-$ impulse excitation

Kai žadinama $2 \mathrm{~Hz}$ dažnių platforma, virpesių amplitudė ant kvazinulinio (neigiamo) standžio sistemos sumažèja 18 kartų, žadinant $4 \mathrm{~Hz}$ dažniu virpesių amplitudè ant izoliavimo sistemos sumažèja 90 kartų, o žadinant $10 \mathrm{~Hz}$ dažniu, virpesių amplitudè sumažèja 100 kartų. Taigi žemieji dažniai izoliuojami efektyviai. Tokios sistemos perduodamumo grafikas, esant harmoniniam žadinimui, parodytas 4.5 pav.

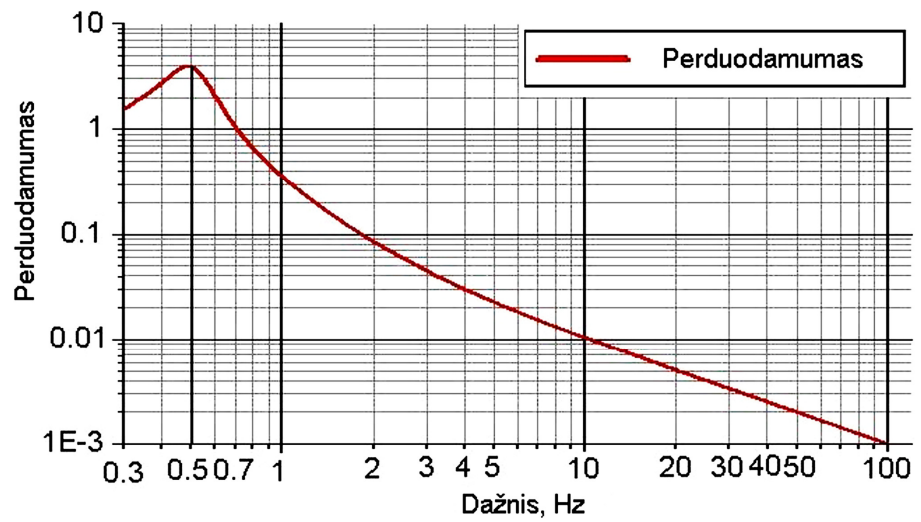

4.5 pav. Kvazinulinio standžio virpesių izoliavimo sistemos perduodamumo grafikas

Fig. 4.5. Transmissibility graphic of isolation system of quasi-zero stiffness 
Iš grafiko 4.5 pav. matyti, kad virpesių izoliavimas prasideda nuo $0,7 \mathrm{~Hz}, \mathrm{o}$ efektyviai pradeda virpesius izoliuoti $0,8-100 \mathrm{~Hz}$ dažnių ruože. Lyginant su teoriniu perduodamumu, matyti, kad kai slopinimo koeficientas yra tarp 0,1 ir 0,25, sutapimo paklaida ivvairiuose dažniuose svyruoja nuo 0,5 iki $1 \%$. Lyginant su neigiamo standžio sistemos perduodamumu, matyti, kad nuo 0,8 iki $3 \mathrm{~Hz}$ kvazinulinès sistemos izoliavimo galimybès yra geresnès, kituose dažniuose - panašios.

\subsection{Sudètinès virpesių izoliavimo sistemos dinaminių charakteristikų eksperimentiniai tyrimai}

Eksperimentiniams tyrimams buvo suprojektuota ir išbandyta speciali virpesių izoliavimo sistema, kurią sudaro virpanti platforma, optinis stalas su pneumatiniais virpesių izoliatoriais ir kvazinulinio (neigiamo) standžio sistema, apkrauta $330 \mathrm{~kg}$ apkrova. Tyrimo metodika ir matavimo priemonès aprašytos pirmiau.

Vibratoriumi buvo sukuriami harmoniniai, impulsiniai ir atsitiktiniai (baltaiss triukšmas) virpesiai $0,1-50 \mathrm{~Hz}$ dažnių diapazone vertikalia kryptimi.

Kompiuteriu matavimo signalai apdorojami naudojant „Origin 7.5“ programini paketa. Valdymo ir registravimo sistemos blokine schema pavaizduota 4.6 pav., a, b, c.

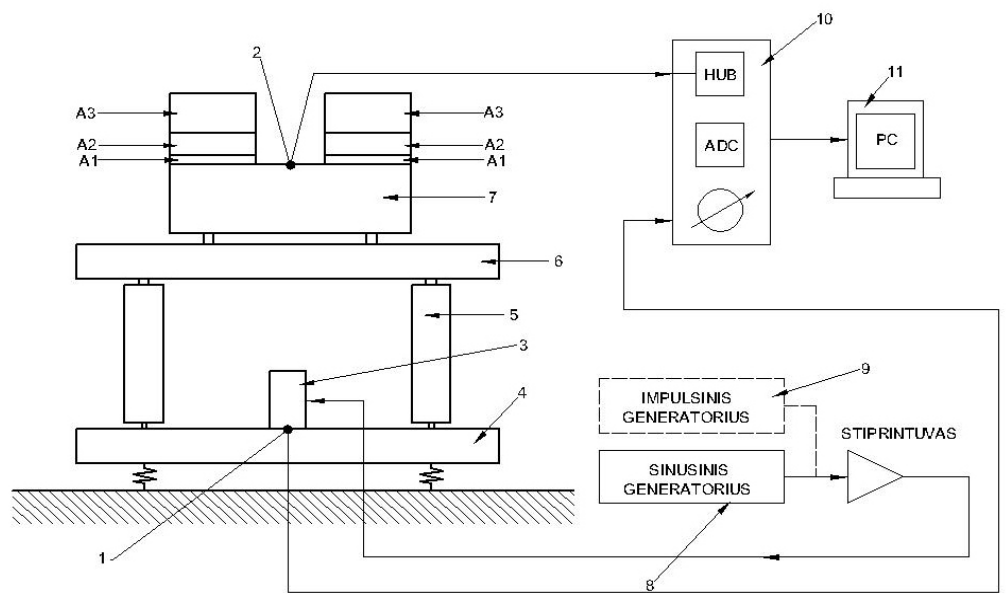



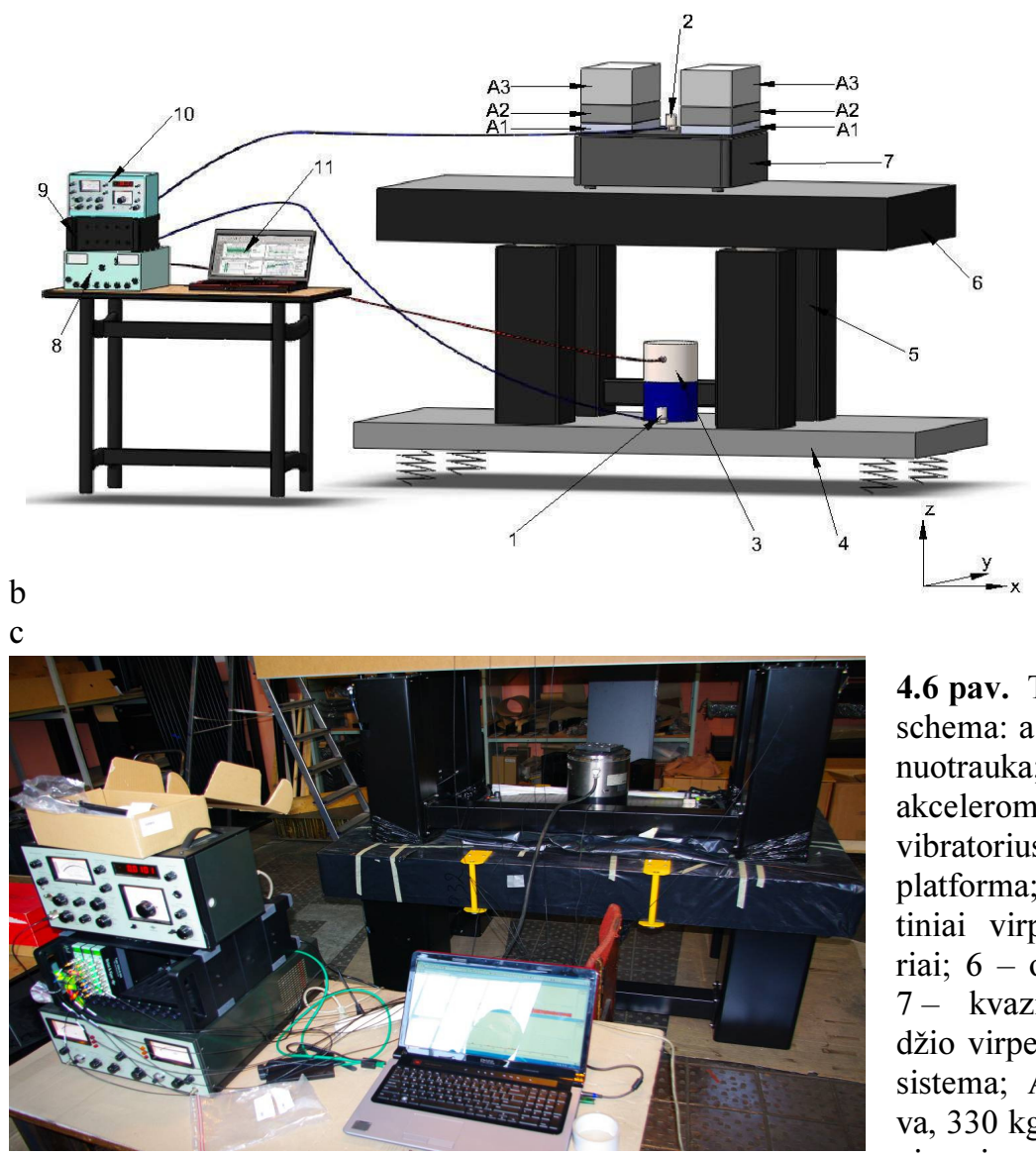

4.6 pav. Tyrimo stendo schema: $\mathrm{a}$ - vaizdas; $\mathrm{b}$ nuotrauka; c: $1-2 \quad-$ akcelerometrai; 3 vibratorius; 4 - virpanti platforma; 5 - pneumatiniai virpesių izoliatoriai; 6 - optinè plokštè; 7 - kvazinulinio standžio virpesių izoliavimo sistema; A1-A3 apkrova, $330 \mathrm{~kg} ; 8$ - sinusinis virpesiu generatorius; 9 - stiprintuvas su virpesių analizatoriumi; 10 - impulsinis virpesių generatorius; 11 matavimo rezultatų apdorojimo izranga „Machine Diagnostics Toolbox Type 9727“ su kompiuteriu DELL

Fig. 4.6. Scheme of a research stand (a), general view (b), photo (c): 1-2 - accelerometers; 3 - vibrator; 4 - vibrating platform; 5 - pneumatic isolators of vibration; 6 - optical plate; 7 - vibration isolation system of a quasi-zero stiffness; A1-A3 load $330 \mathrm{~kg} ; 8$ sinusoidal vibration generator; 9 - amplifier with vibration analyzer; 10 - impulse vibration generator; 11 - equipment of handling of measurement results "Machine Diagnostics Toolbox Type 9727" with computer DELL

Žemojo dažnio virpesių laikinès charakteristikos parodytos 4.7 pav., a, b, c, d. 


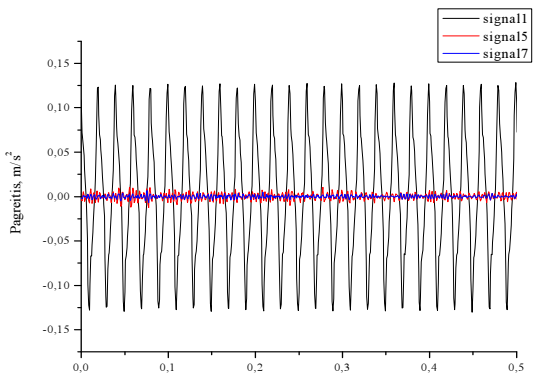

a

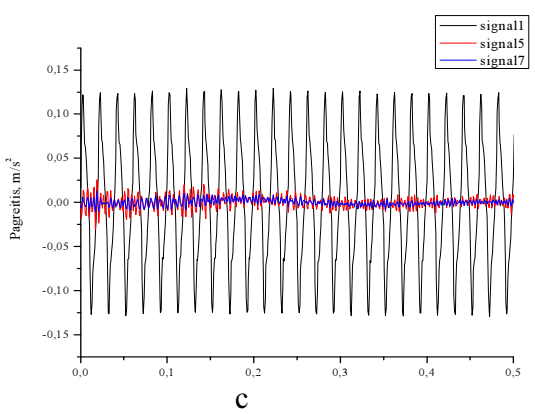

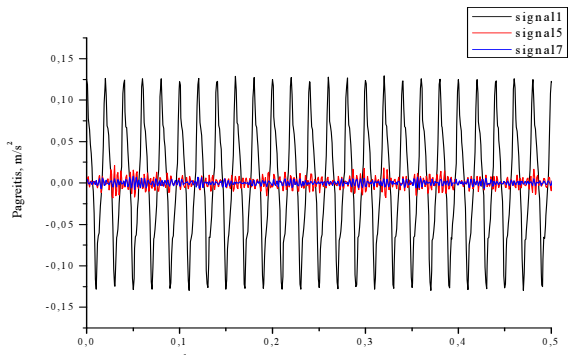

b

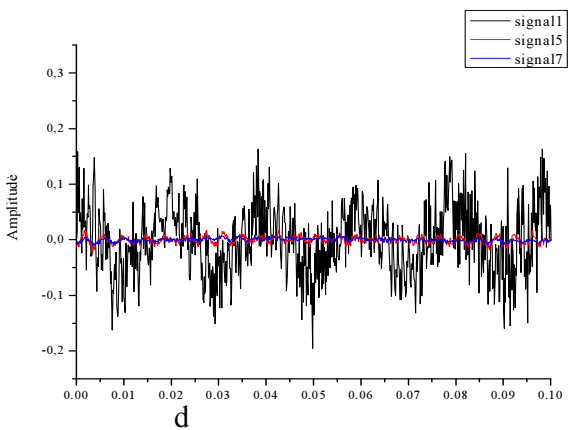

4.7 pav. Sudètinès sistemos žemjoo dažnio virpesių izoliavimas: a - harmoninis $0,8 \mathrm{~Hz}$ žadinimas; $\mathrm{b}$ - harmoninis $1 \mathrm{~Hz}$ žadinimas; $\mathrm{c}$ - harmoninis $2 \mathrm{~Hz}$ žadinimas; $\mathrm{d}-$ atsitiktinis (baltasis triukšmas) žadinimas

Fig. 4.7. Isolation of low frequency vibrations of a complex system: a - harmonic excitation of $0,8 \mathrm{~Hz} ; \mathrm{b}-$ harmonic excitation of $1 \mathrm{~Hz}$; $\mathrm{c}$ - harmonic excitation of $2 \mathrm{~Hz} ; \mathrm{d}$ - random excitation (white noise)

Gauti rezultatai rodo, kad žemieji $0,8-2 \mathrm{~Hz}$ dažniai izoliuojami efektyviai, o 3-10 Hz virpesiai izoliuojami neefektyviai, daugiau nei 10 iki $50 \mathrm{~Hz}$ dažnio virpesiai gerai izoliuojami. Tokios sudètinès sistemos tinkamos tik siaurame žemųjų 0,8-2 Hz dažnių ruože, aukštesniuose dažniuose daugiau nei $10 \mathrm{~Hz}$ virpesius gerai izoliuoja kvazinulinio standžio sistema ir optinis stalas, todèl nèra reikalo naudoti tokių sudètingų sistemų, nes sumažinti optinès plokštès masę ir išlaikyti reikiamą standumą yra problemiška. 

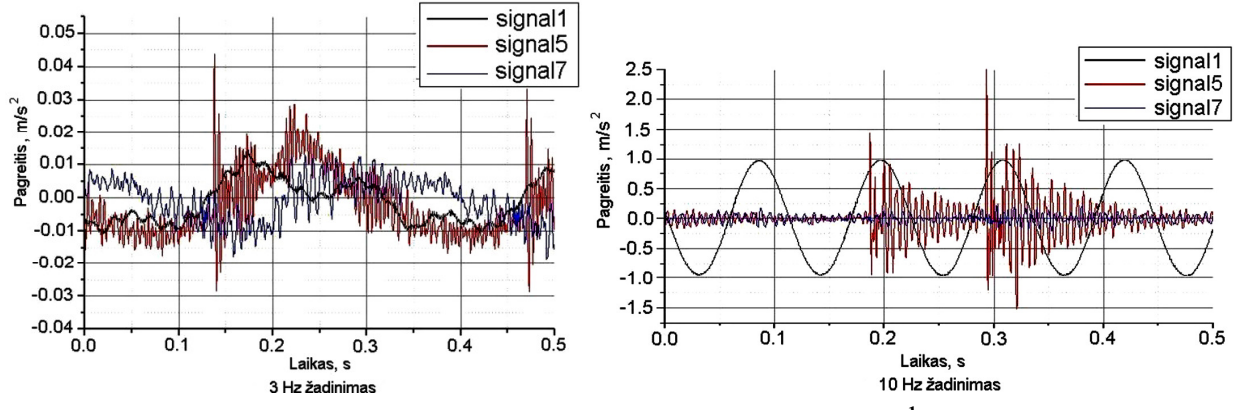

a

$\mathrm{b}$

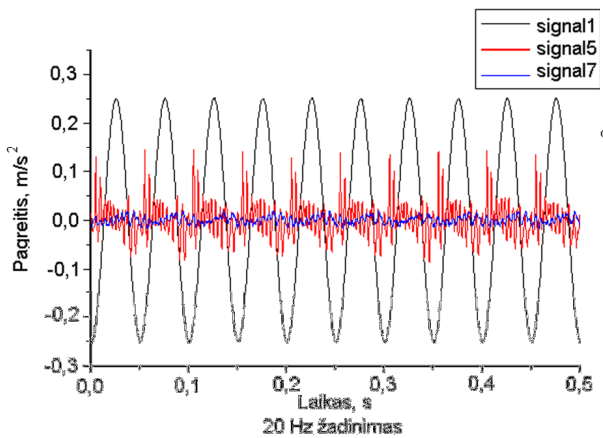

$\mathrm{c}$
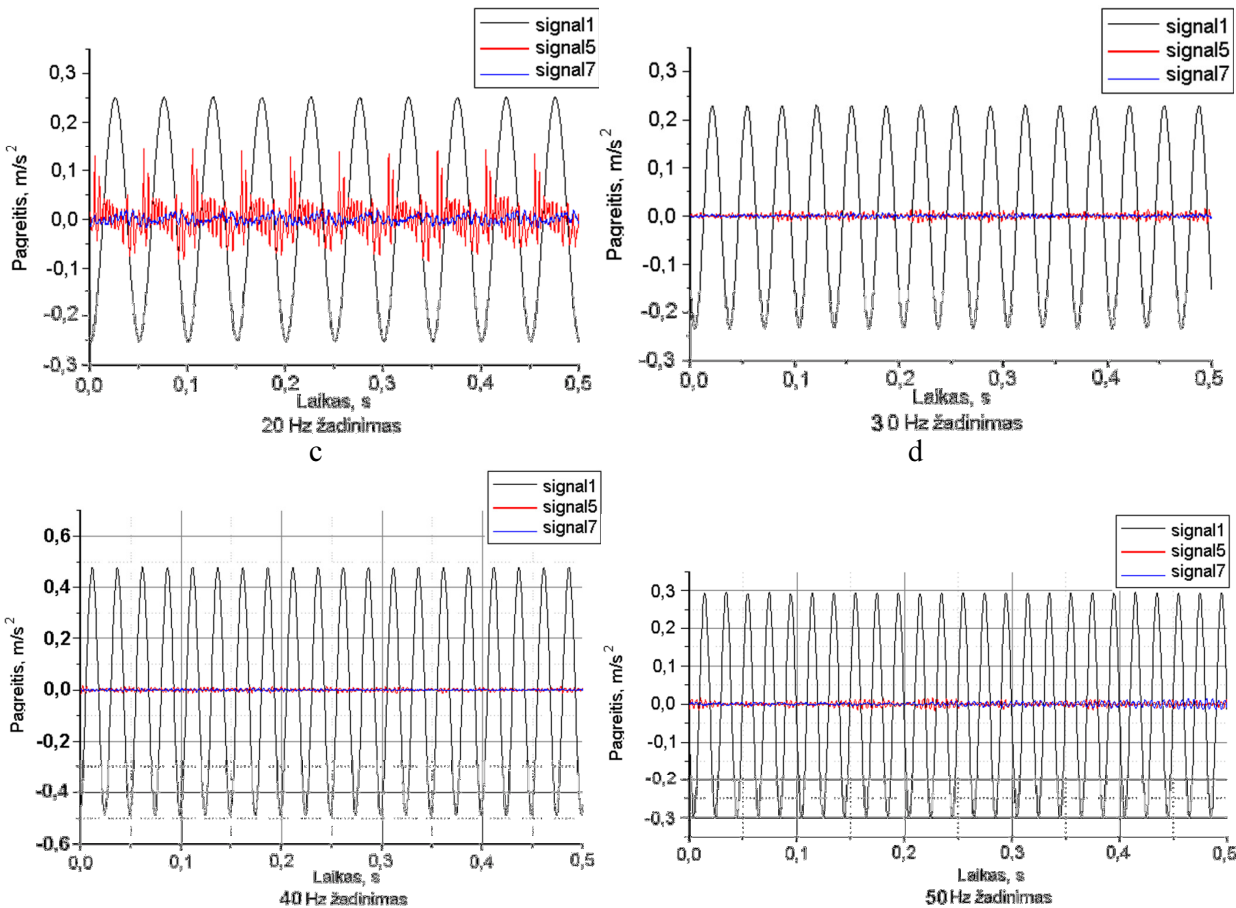

$\mathrm{e}$

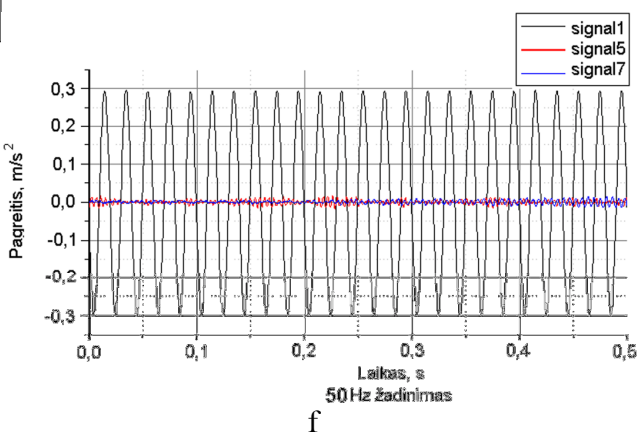

4.8 pav. Sudètinès sistemos harmoninių virpesių izoliavimo rezultatai:

a $-3 \mathrm{~Hz}$ žadinimas; $\mathrm{b}$ - $10 \mathrm{~Hz}$ žadinimas; $\mathrm{c}-20 \mathrm{~Hz}$ žadinimas; $\mathrm{d}-30 \mathrm{~Hz}$ žadinimas; e $-40 \mathrm{~Hz}$ žadinimas; $\mathrm{f}-50 \mathrm{~Hz}$ žadinimas

Fig. 4.8. Results of isolation of harmonic vibrations of a complex system: a - excitation of $3 \mathrm{~Hz}$; b - excitation of $10 \mathrm{~Hz}$; - excitation of $20 \mathrm{~Hz}$; d - excitation of $30 \mathrm{~Hz}$; $\mathrm{e}-$ excitation of $40 \mathrm{~Hz} ; \mathrm{f}$ - excitation of $50 \mathrm{~Hz}$

Sudètinès sistemos perduodamumo grafiko eksperimentiškai gauti nepavyko dèl pirmiau minètu priežasčių. Teoriškai tokios sistemos gali veikti, jeigu 
optinès plokštės masė, lyginant su krovinio mase, būtų labai maža. Praktiškai tokios sudètingos sistemos, lyginant su naujai sukurtomis, papildomų pranašumų nesuteiktų.

\subsection{Virpesių matavimo rezultatų neapibrèžties tyrimai}

Virpesių matavimo rezultatų patikimumas gali būti apibūdinamas matavimo neapibrezžties ịverčiu. Pavyzdžiui, kuo mažesnè matavimo rezultatų neapibrèžtis, tuo mažiau iškreipiama informacija ir tiksliau atvaizduojama reali techninè objekto būklè (Weise 1993).

Jei nagrinèsime paprasčiausią virpesių matavimo kanalą, šio kanalo matavimo neapibrežties itakos faktorių diagramą galima atvaizduoti taip, kaip pateikta 4.7 pav. (Kilikevičius 2009).

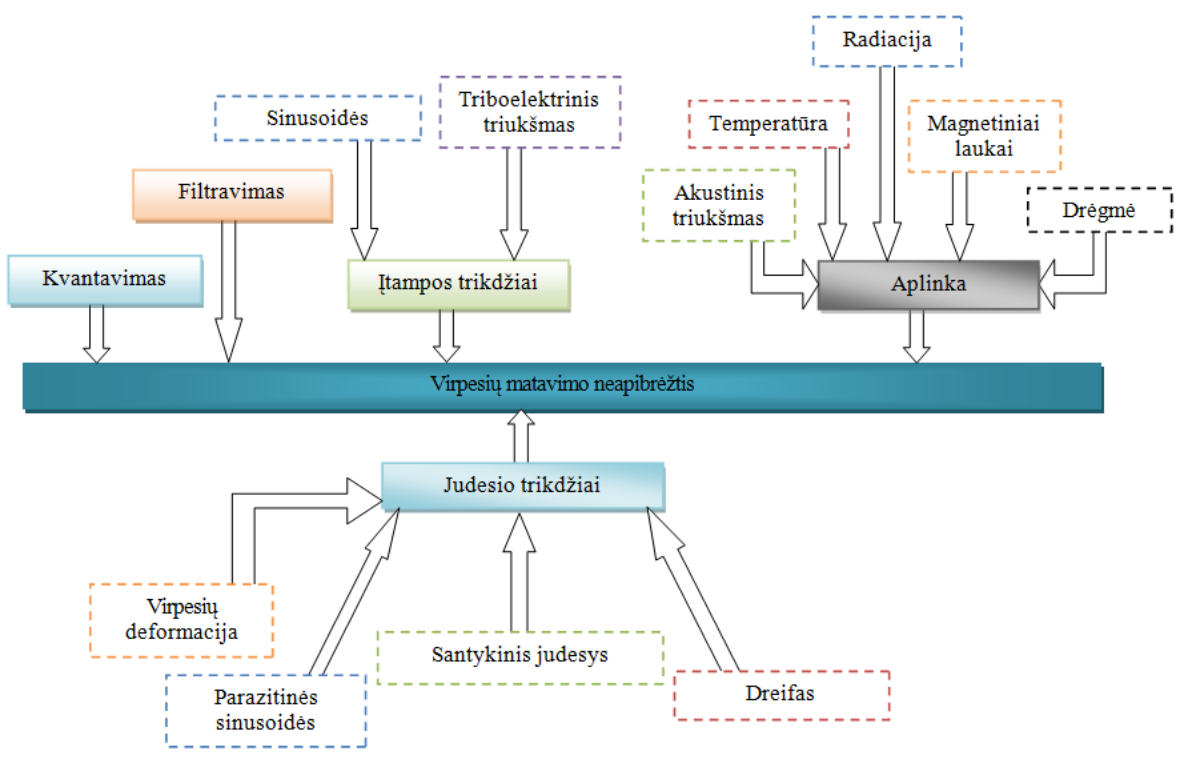

4.9 pav. Virpesių matavimo neapibrèžties įtakos faktorių išsidèstymas

(Kilikevičius 2009)

Fig. 4.9. The distribution of factors affecting the vibration measurement uncertainty

(Kilikevičius 2009)

Analizuojant daugiakanalę virpesių matavimo sistemą, daroma prielaida, kad tai yra matavimo sistemu aibé, sudaryta iš $n$ virpesių matavimo kanalų. Kiekvieno virpesių matavimo kanalo matavimo patikimumą galima apibūdinti atskiru neapibrèžties įverčiu. Daroma prielaida, kad kanalai, matuojantys tą pati 
virpesių parametra, veikia tomis pačiomis sąlygomis ir keitlių atsakas aplinkos poveikiui (4.9 pav.) yra vienodas, todèl teigiama, kad neapibrěžtis atskiriems kanalams yra vienoda, skiriasi tik statistinis atskiro kanalo matavimo neapibrèžties sandas (Eidukevičiūtė 2006, 2007).

Virpesių matavimo rezultatų neapibrèžties ịtakos faktorių analizė. Analizuojant virpesių matavimo rezultatų patikimumo problematiką, būtina ištirti virpesių matavimų neapibrěžties modelio įtakos faktorius. Virpesių matavimo neapibrèžties įtakos faktorių dedamosios pagal kilmę gali būti skirstomos ị:

- prietaiso paklaidu dedamosios: kiekvienam matavimo itaisui kalibravimo metu apskaičiuojama kalibravimo neapibrěžtis. Ši neapibrěžties dedamoji turi būti įtraukiama ị bendraji matavimo neapibréžties modelị;

- aplinkos poveikio dedamosios: virpesių matavimo sistemų tikslas - pagal išmatuotus virpesius ịvertinti mašinos būklę. Dauguma stebimų mašinų dirba nelaboratorinèmis sąlygomis, tad dèl aplinkos poveikio gali būti netikslumų išmatuotoje virpesių dydyje, kuris savo ruožtu daro įtaką galutiniam priimamam sprendimui ir jo pasekmėms (Giniotis et al. 2004).

Nors kiekvienas keitlys turi nurodytą savo kalibravimo neapibrèžtí ji nèra nekintama ir nepaveikiama. Todèl atsižvelgiant i matavimo posistemio atskirų prietaisų kalibravimo ir patikros periodiškumą, reikètų ivvertinti ir matavimo prietaisų i̇takos faktorius, kurie gali turèti įtakos virpesių matavimams. Literatūros analizè leidžia ivvardyti šiuos pagrindinius virpesių matavimų aparatūros, pvz., virpesių keitlio paklaidų šaltinius (4.10 pav.) (Quinn 1994; Brüel 1998):

- neteisingas keitlio perduodamumo koeficiento nustatymas;

- dažninès amplitudès charakteristikos netolygumas;

- amplitudès charakteristikos netiesiškumas;

- dažninès fazès charakteristikos netolygumas;

- keitlio skersinio jautrumo netikslumas;

- pakitęs keitlio jautrumas dèl deformacijos, atsirandančios keitlio tvirtinimo vietoje.

Virpesių matavimo prietaiso amplitudès dažnio charakteristikos netolygumas vertinamas pagal šią formulę (Isermann 1997; Eidukevičiūtè 2006; Eidukevičiūtė 2007):

$$
\gamma_{\text {mat }}=\frac{\Delta X_{\max }}{X_{\delta}},
$$

čia $\Delta X_{\max }-$ maksimalus prietaiso rodmens nuokrypis nuo reikšmès, gautos esant nustatytam dažniui; $X_{\delta}$ - prietaiso rodmuo, esant fiksuotam dažniui. 


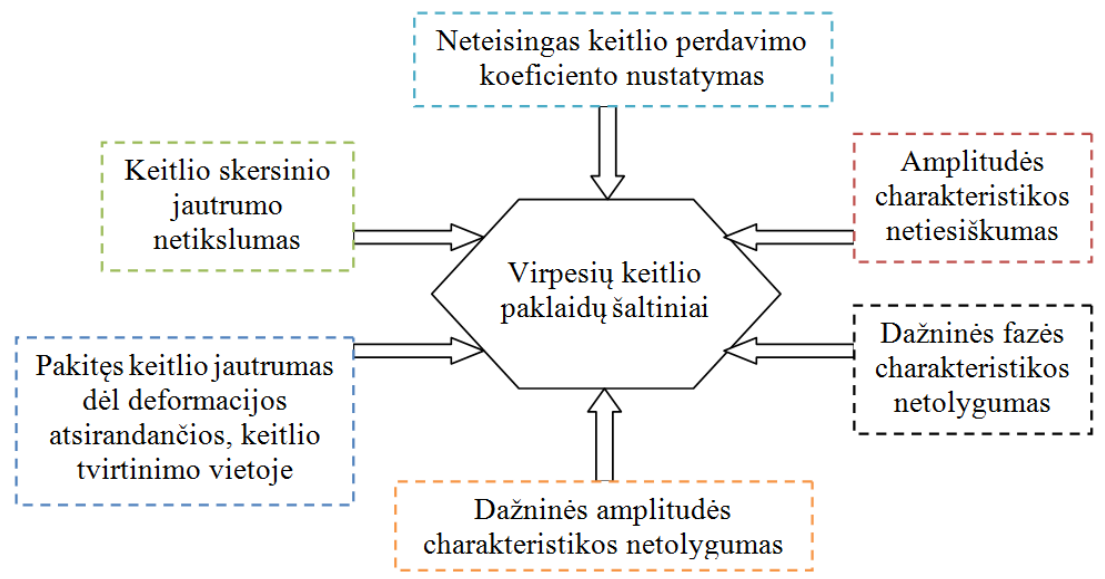

4.10 pav. Virpesių keitlio paklaidų šaltiniai (Quinn 1994; Bruel 1998)

Fig. 4.10. Vibration transducer errors sources (Quinn 1994,; Bruel 1998)

Prietaiso perduodamumo koeficientas $\hat{K}$ gali būti vertinamas pagal šią formulę:

$$
\hat{K}_{a}=\frac{V_{\delta}}{\gamma_{s} \cdot \bar{a}}
$$

arba

$$
\hat{K}_{v}=\frac{V_{\delta}}{\bar{v}},
$$

čia $V_{\delta}$ - itampos matavimo prietaiso rodmuo, esant pagrindiniam dažniui, $\mathrm{mV}$; $\hat{K}_{a}$ - perduodamumo koeficiento verte pagreičiui, $\mathrm{mV} / \mathrm{mm} \mathrm{s}^{-2} ; \hat{K}_{v}$ - perduodamumo koeficiento verte greičiui, $\mathrm{mV} / \mathrm{mm} \mathrm{s}^{-1} ; \bar{a}$ - vibracinio pagreičio vertè, $\mathrm{mm} / \mathrm{s}^{2} ; \bar{v}$ - vibracinio greičio verte, $\mathrm{mm} / \mathrm{s} ; \gamma_{\mathrm{s}}-$ stiprintuvo perduodamumo koeficientas (jei stiprintuvo nèra, $\gamma_{s}=1$ ).

Tada skersinio santykinio transformacijos $K_{s s}$ koeficientas apskaičiuojamas pagal šią formulę (Kilikevičius 2009):

$$
K_{s s}=\frac{V_{\max }}{\gamma_{s} \cdot \bar{a} \cdot \hat{K}_{a}},
$$

čia $V_{\max }-$ itampos matavimo prietaiso rodmuo. 
Amplitudès dažnio charakteristikos netolygumas apibūdinamas šiuo santykiu:

$$
\gamma=\frac{\left|V_{r}-V_{\delta}\right|_{\max }}{V_{\delta}}
$$

čia $V_{r}$ - itampos matavimo prietaiso maksimalus arba minimalus voltmetro rodmuo, $\mathrm{mV} ; V_{\delta}$ - prietaiso rodmuo, esant fiksuotam dažniui.

Amplitudès charakteristikos netiesiškumas aprašomas formule

$$
\delta_{a}=\frac{K_{i}-K_{v i d}}{K_{v i d}},
$$

čia $K_{i}$ - perduodamumo koeficientas $z$-tajai vibracinio pagreičio arba vibracinio greičio vertei; $K_{v i d}$ - vidutinè perduodamumo koeficiento vertè.

Dažninès amplitudès charakteristikos netolygumo charakteristika $\gamma_{\text {mat }}$ pasiskirsčiusi pagal trikampi tikimybini pasiskirstymo dèsnị. Šis skirstinys rodo, kad tikimybe $P$, jog charakteristika igis vidutinę reikšmę, yra didžiausia ir tolygiai mažèja kitose intervalo vietose. Neapibrèžties ịvertis skaičiuojamas pagal šią formulę (Eidukevičiūtè 2007):

$$
u_{m a t}^{2}=\frac{1}{6} \frac{\Delta X_{\max }\left(X_{\delta \max }-X_{\delta \min }\right)}{X_{\delta \min } X_{\delta \max }} .
$$

Vibrometro transformacijos koeficiento ịvertis pasiskirstęs pagal stačiakampi dèsni. Tai reiškia, kad tikimybè, jog koeficientas igis bet kurią reikšmę, iš paklaidos intervalo yra vienoda. Šio koeficiento standartinę neapibrèžti galima išreikšti taip:

$$
u_{\hat{K}_{a}}^{2}=\frac{V_{\delta \max }-V_{\delta \min }}{3 \gamma_{s} \bar{a}}
$$

arba (jei matuojamas greitis) -

$$
u_{\hat{K}_{v}}^{2}=\frac{V_{\delta \max }-V_{\delta \min }}{3 \bar{v}} .
$$

Skersinio santykinio transformacijos koeficiento paklaida pasiskirsčiusi pagal stačiakampi pasiskirstymo dèsnị: 


$$
u_{K_{s s}}^{2}=\frac{V_{\max }\left(\hat{K}_{a \max }-\hat{K}_{a \min }\right)}{\gamma_{s} \cdot \bar{a} \cdot \hat{K}_{a \min } \cdot \hat{K}_{a \max }} .
$$

Kai atliekami nuolatiniai virpesių matavimai, išauga matuojamujų dydžių imties tūris $N$, o statistinis neapibrěžties sandas, apskaičiuojamas pagal formulę $u_{\text {stat }}=\frac{S_{X}}{\sqrt{N}}$, yra priklausomas nuo dydžio $N$.

Šis dydis, tęsiant matavimus ir didejjant $N$ skaičiui, mažèja. Standartinis nuokrypis (Čekanavičius 2004, 2006), išreiškiamas formule $S_{X}^{2}=\frac{\sum_{j=1}^{N}\left(x_{j}-\bar{x}\right)^{2}}{N-1}$, savo ruožtu taip pat priklauso nuo imties tūrio, ir jam didèjant, artejja prie vieneto. Statistinio neapibrèžties sando $u_{\text {stat }}$ dydis lygus standartinio vidurkio nuokrypio $S_{\bar{x}}$ reikšmei (Vekteris 2000). Dar šią lygtị būtu galima užrašyti taip:

$$
u_{\text {stat }}=\sqrt{\frac{\sum_{i=1}^{N}\left(x_{i}-\bar{x}\right)^{2}}{N-1}} \cdot \frac{1}{\sqrt{N}} \approx \frac{\sqrt{\sum_{i=1}^{N}\left(x_{i}-\bar{x}\right)^{2}}}{N} .
$$

čia $x_{i}$ - imties narys; $\bar{x}-$ imties vidurkis.

Virpesių matavimo neapibrèžties įtakos faktorių aplinkos atžvilgiu dedamosios - temperatūros $T$ ir drègmès $H$ sandai, atitinkamai $u_{T}^{2}$ ir $u_{H}^{2}$. Šie faktoriai tarpusavyje koreliuoja ir gali paveikti matavimų neapibrèžti. Jų koreliacinè dedamoji:

$$
u_{\text {korel }}^{2}=2 \cdot u_{T} u_{H} r(T, H) .
$$

Tačiau virpesiai buvo matuojami patalpoje, kurioje palaikomi pastovūs drègmè ir temperatūra, tai ši koreliacija neapibrèžties modeliui įtakos neturi.

Neapibrèžties modelio tyrimas. Remiantis šiame skyriuje nurodytais itakos faktoriais, nuolatinio virpesių matavimo rezultatų neapibrežties įvertinimo pagrindiniai faktoriai pateikti 4.2 lenteleje (Vekteris 2000; Volkovas 2004).

Remiantis realiais duomenimis, apskaičiavus statistini neapibrèžties ịverti $u_{\text {stat }}^{2}$, pagal išmatuotus duomenis ir remiantis pirmiau pateiktomis prielaidomis (Eidukevičiūtè 2007; Volkovas 2004), virpesių matavimo sistemos rezultatų neapibrèžties modelis: 


$$
U_{V M S}=2 \cdot \sqrt{u_{\text {stat }}^{2}+u_{\text {mat }}^{2}+u_{\hat{K}}^{2}+u_{K_{s s}}^{2}+u_{T}^{2}+u_{H}^{2}+2 \cdot u_{T} u_{H} r(T, H)+u_{\text {stip }}^{2}+u_{\text {keit }}^{2}+u_{\text {mat,duom }}^{2}+u_{t r}^{2}},
$$

čia $u_{\text {stat }}$ - statistinis neapibrèžties sandas; $u_{\text {mat }}$ - matavimo prietaiso neapibrěžties sandas; $u_{\hat{K}}^{2}$ - prietaiso perduodamumo koeficiento neapibrèžties sandas; $u_{K_{s s}}^{2}-$ transformacijos koeficiento neapibrèžties sandas; $\boldsymbol{u}_{T}$ - temperatūros itakos neapibrèžties sandas; $u_{H}$ - drègmès įtakos neapibrěžties sandas; $u_{\text {stip }}$ - pirminio signalo stiprinimo neapibréžties sandas; $u_{\text {keit }}$ - analoginio signalo keitimo į skaitmenini kodą neapibrèžties sandas; $u_{\text {mat,duom }}$ - matavimo duomenų apdorojimo neapibrèžties sandas; $u_{t r}$ - triukšmo itakos neapibrèžties sandas.

4.1 lentelè. Pagrindiniai virpesių matavimo sistemos rezultatų neapibrèžties įvertinimo faktoriai

Table 4.1. Vibration measurements in the assessment of the uncertainty of main factors

\begin{tabular}{|c|c|c|}
\hline Žymuo & Aprašymas & $\begin{array}{l}\text { Neapibrèžties } \\
\text { ivertinimo metodas }\end{array}$ \\
\hline$u_{\text {stat }}$ & $\begin{array}{l}\text { Statistinis neapibrèžties sandas, apskaičiuojamas iš } \\
\text { matavimo duomenų }\end{array}$ & $A$ \\
\hline$u_{\text {mat }}$ & $\begin{array}{l}\text { Matavimo priemonės kalibravimo neapibrèžtis, nuro- } \\
\text { doma matavimo priemonès dokumentuose }\end{array}$ & $\boldsymbol{B}$ \\
\hline$u_{K}, u_{K s s}$ & $\begin{array}{l}\text { Neapibrèžties sandai, atsirandantys dèl besikeičiančiu } \\
\text { matavimo priemonès } \\
\text { charakteristikų }\end{array}$ & $\boldsymbol{B}$ \\
\hline$u_{T}, u_{H}$ & $\begin{array}{l}\text { Neapibrèžties sandai, atsirandantys dèl besikeičiančių } \\
\text { aplinkos sąlygų }\end{array}$ & $\boldsymbol{B}$ \\
\hline$u_{\text {stip }}$ & Pirminio signalo stiprinimo neapibrèžties sandas & $\boldsymbol{B}$ \\
\hline$u_{\text {keit }}$ & $\begin{array}{l}\text { Analoginio signalo keitimo ị skaitmenini kodą neapi- } \\
\text { bréžties sandas }\end{array}$ & $\boldsymbol{B}$ \\
\hline$u_{\text {mat,duom }}$ & Matavimo duomenų apdorojimo neapibrèžties sandas & $\boldsymbol{B}$ \\
\hline$u_{t r}$ & $\begin{array}{l}\text { Neapibrèžties sandas, atsirandantis dèl triukšmingos } \\
\text { aplinkos, } \\
\text { vertinamas iš turimų duomenų }\end{array}$ & $A$ \\
\hline
\end{tabular}


Naudojant šiame skyriuje pateiktą matavimo rezultatų neapibrèžties nustatymo metodika, virpesių matavimo rezultatų neapibrèžties įverčiai (ịvertinant imties standartinį nuokrypi kaip reikšminị dydị) pateikti (4.12) ir (4.13) formulèse. Virpesių matavimo rezultatų neapibrèžtis buvo vertinama, kai buvo matuojami harmoniniai, impulsiniai ir atsitiktiniai absoliutūs virpesiai $(3.1,3.8,3.13$, 4.1, 4.6 pav.). Buvo atlikti šeši matavimai ir įvertintos šių matavimų vidutinès parametrų reikšmès. Virpesių matavimo rezultatų ir neapibrèžties įvertinimas pateiktas 4.2 lentelèje.

4.2 lentelè. Virpesių matavimo rezultatų ir neapibrèžties ịvertinimas

Table 4.2. Results of the vibration measurements and the assessment of the uncertainty

\begin{tabular}{|l|c|c|c|}
\hline $\begin{array}{l}\text { Virpesių mata- } \\
\text { vimo rezultatai }\end{array}$ & $\begin{array}{c}\text { Aritmetinio } \\
\text { vidurkio } \\
\text { reikšmė } \bar{x}, \\
\boldsymbol{\mu m}\end{array}$ & $\begin{array}{c}\text { Standartinio } \\
\text { nuokrypio } \\
\text { iverčio } \boldsymbol{S}_{\boldsymbol{x}}, \\
\boldsymbol{\mu m}\end{array}$ & $\begin{array}{c}\text { Statistinio neapibrěžties } \\
\text { sando reikšmė } \boldsymbol{u}_{\text {stat }}, \boldsymbol{\mu \mathrm { m }}\end{array}$ \\
\hline $\begin{array}{l}\text { Absoliučių virpe- } \\
\text { sių }\end{array}$ & $-0,0993$ & 0,2039 & 0,00160 \\
\hline
\end{tabular}

Iš 4.2 lentelèje pateiktų rezultatų matyti, kad dèl didelio duomenų kiekio statistinè neapibrěžties dedamoji, nusakanti pagrindinị skirtumą tarp duomenų (kai matuojami absoliutūs virpesiai), yra nedidelè, tada neapibrèžties îvertis, laikant statistinį neapibrěžties sandą nereikšmingu, būtų toks:

$$
U_{V M S a}=2 \cdot \sqrt{u_{m a t}^{2}+u_{\hat{K}}^{2}+u_{K_{s s}}^{2}+u_{\text {stip }}^{2}+u_{k e i t}^{2}+u_{m a t, d u o m}^{2}} .
$$

Temperatūros ir drègmès neapibrèžties sandai prilyginami nuliui. Triukšmo dedamoji taip pat prilyginama nuliui, nes yra nykstamai maža, mat patalpa, kurioje atliekami matavimai, yra izoliuota nuo išorinių triukšmo šaltinių. Absoliučių virpesių matavimo rezultatų neapibrěžtis:

$$
U_{V M S a}=0,45 \% \text {. }
$$




\subsection{Ketvirtojo skyriaus išvados}

1. Nustatyta, kad kvazinulinio standžio virpesių izoliavimo sistema gerai izoliuoja žemojo dažnio virpesius $0,7-50 \mathrm{~Hz}$ dažnių juostoje.

2. Sudètinè virpesių izoliavimo sistema tinkama izoliuoti virpesius tik nuo 0,8 iki $2 \mathrm{~Hz}$ dažnių juostoje ir nuo 10 iki $50 \mathrm{~Hz}$ dažnių juostoje, o nuo 3 iki $10 \mathrm{~Hz}$ dažnio juostoje veikia kaip stiprintuvas ir virpesių neizoliuoja.

3. Sudarytas virpesių matavimo rezultatų neapibrèžties įvertinimo modelis, išnagrinèti matavimo neapibrèžties sandai.

4. Atliktas absoliučių virpesių amplitudžių apibrezžties ịvertinimas rodo matavimo kokybę. Nustatyta absoliučių virpesių matavimo rezultatų neapibrèžtis $-0,45 \%$. 



\section{Bendrosios išvados}

1. Literatūros šaltinių analizè rodo, kad pasyviujuc ir aktyviujų metodų taikymas žemojo dažnio virpesiams izoliuoti yra nepakankamas arba labai brangus, kai izoliavimo objektai, precizinès svarstyklès, optiniai mikroskopai ir kita jautri iranga, esanti palydovuose, orbitinèse stotyse, orbitiniuose teleskopuose, veikiama vakuumo, aukštos arba žemos temperatūros, smarkių virpesių arba radiacijos.

2. Mechaninès koncepcijos kvazinulinio standžio žemojo dažnio virpesių izoliavimo sistemos analitinis tyrimas parodè, kad virpesių izoliavimas prasideda nuo $0,7 \mathrm{~Hz}$ dažnio, dažniui didejjant izoliavimo efektyvumas dideja. Remiantis tyrimu gautas kvazinulinio standžio virpesių izoliavimo sistemos patentas.

3. Analitiškai ištirti sudètinès virpesių izoliavimo sistemos dinaminiai parametrai ir nustatyta, kad tokios sistemos gerai slopina žemojo dažnio virpesius nuo $0,8 \mathrm{~Hz}$, kai optinio stalo plokštès masé nevertinama, t. y. kai nagrinèjama vienmasè sistema.

4. Pasiūlyta ir aprobuota korinès konstrukcijos plokščių ir pneumatinių virpesių izoliatorių eksperimentinio tyrimo ir dinaminių parametrų nustatymo metodika. Pateikti tyrimo rezultatai rodo, kad korinès konstrukcijos optinių plokščiu ir platformos dinaminio slankio kreivès iki $80 \mathrm{~Hz}$ yra tiesès, tai 
reiškia, kad jos yra absoliučiai standžios, pirmas rezonansas prasideda nuo $199 \mathrm{~Hz}$, o dinaminio įlinkio koeficientai ir maksimalūs reliatyvūs plokščių judejjimai atitinka geriausių gamintojų reikalavimus, stalų pneumatinių izoliatoriu virpesiu perduodamumas vertikalia, horizontalia skersine ir horizontalia išilgine kryptimi nusako izoliavimo galimybes, kurios prasideda nuo $5 \mathrm{~Hz}$, o rezonansiniai dažniai, atsižvelgiant ị apkrovą, svyruoja nuo 3,1 iki $3,9 \mathrm{~Hz}$, tai atitinka teorinių tyrimų rezultatus su 1 proc. paklaida.

5. Sukurta virpesių izoliavimo sistemų dinaminiu parametrų nustatymo metodika gali būti taikoma optinių stalų ir kitų mechaninių žemojo dažnio virpesių izoliavimo sistemoms projektuoti, eksploatavimo metu randant efektyvias izoliatorių struktūras, jų parametrų vertes, kitimo dėsnius, optimizuojant tokių sistemu parametrus, kai yra nežinomos atsitiktiniu sistemą veikiančių virpesių dinaminès charakteristikos, kintančios laike.

6. Eksperimentiškai nustatyta, kad kvazinulinio standžio virpesių izoliavimo sistema gerai izoliuoja žemojo dažnio virpesius $0,7-50 \mathrm{~Hz}$ dažnių juostoje. Teorinio ir eksperimentinio virpesių perduodamumo nesutapimo paklaida, esant atskiriems dažniams, svyruoja nuo 0,5 iki 1 proc.

7. Eksperimentiškai ištirtos sudètinių sistemų dinaminès charakteristikos ir nustatyta, kad sudètinè virpesių izoliavimo sistema tinka izoliuoti virpesius tik nuo 0,8 iki $2 \mathrm{~Hz}$ dažnių juostoje ir nuo 10 iki $50 \mathrm{~Hz}$ dažnių juostoje, o nuo 3 iki $10 \mathrm{~Hz}$ dažnio juostoje veikia kaip stiprintuvas ir virpesių neizoliuoja. Taigi tokioms sistemoms kurti reikia papildomų tyrimų, siekiant gauti vienos masès sistemą. 


\section{Literatūra ir šaltiniai}

Alanoly, J.; Sankar, S. 1987. A new concept in semi-active vibration isolation, ASME Journal of Mechanisms, Transmissions, and Automation in Design 109: 242-247.

Anderson, E.; Donald, H.; Leo, L; Holcomb, M. D. 1996. Active system for vibration isolation of spacecraft instruments, in $19^{\text {th }}$ Annual AAS Quidance and Control Conference, February 7-11, 1996 Breckenridge, Colorado, 120-131.

Anderson, E.; John, H.; Fumo, P.; Scott Erwin, R. 2000. Satellite ultraquiet isolation technology experiment, in Proceedings of IEEE Aerospace Conference, 299-313.

Augustaitis, V. K. 2000. Mechaniniu virpesiu pagrindai: vadovèlis. Vilnius: Žiburio leidykla. $316 \mathrm{p}$.

Benaroya, H. 2004. Mechanical vibration. Marcel Dekker. New York. 712 p. ISBN: 08247-5380-1

Beranek, L. L.; Ver, I. L. 1992. Noise and vibration control engineering:principles and applications. John Wiley and Sons.

Bernhard, R. J.; Hall, H. R.; Jones, J. D. 1992. Adaptive-passive Noise Control. InterNoise. Toronto, Ontario, Canada.

Bies, D. A.; Hansen, C. H. 1996. Engineering noise control. 2nd Edition. UK: E \& FN Spon.

Bock, G. Schwingungsdamfung unter Ausnuzung der Werkstoff. ZAMM, 1932, Bd. 12. 
Bolotin, V. V. 1966. Broadband random vibration of elastic systems, Intern. Journ. Of solids and struct. 2(1): 105-124.

Brüel, K. 1998. Vibrations transducers and Signal Conditioning.

Cessaro, R. K. 1994. Bull. Seismol. Soc. Am. 84. 142 p.

Choi, S.-B.; Kim, W.-K. Vibration control of a semi-active suspension featuring electrorheological fluid dampers, Journal of Sound and Vibration.

Connolly, C. 2009. Vibration isolation theory and practice, Assembly Automation 29(1): 8-13.

Crandall, S. H.; Mark, W. D. 1963 Random vibration in mechanical systems. Academic Press.

Crosby, M. J.; Karnopp, D. C. 1973. The active damper: a new concept for shock and vibration control, Shock and Vibration Bulletin 43: 119-133.

Čekanavičius, V. Murauskas, G. 2006. Statistika. Vilnius: Technika. 239 p. ISBN 9986546-93-1.

Čekanavičius, V.; Murauskas, G. 2004. Statistika II. Vilnius: Technika. 272 p. ISBN 9955-491-16-7.

Čirkov, V. P. 1975. Slučainyje kolebanija tonkostennich konstrukcii, nesuščich sosredotočennije masi, Izv. AN SSSR, MTT 3: 159-164.

Eidukevičiūtè, M. 2007. Rotoriniu mašinu virpesiu monitoringo neapibréžčiu ir diagnostikos patikimumo tyrimas: daktaro disertacija. Kaunas: Technologija.

Eidukevičiūte, M.; Volkovas, V. 2006. On the impact of vibration measurement uncertainty to diagnostics in vibromonitoring systems, in Vibroengineering 2006: Proceedings of the 6th International Conference, Kaunas University of Technology, 116-120, ISSN 1822-1262.

Elliott, S. J.; Serrand, M.; Gardonio, P. 2001. Feedback stability limits for active isolation systems with reactive and inertial actuators, ASME Journal of Vibration and Acoustics 123: 250-162.

Ferry, D. K. 2007. Negative-stiffness vibration isolation improves reliability of nanoinstrumentation, Laser Focus Word, October 2007.

Firmos „Standa“ gaminių katalogas „Opto-Mechanical Products 2012“.

Franchek, M. A.; Ryan, M. W; Bernhard R. J. 1995. Adaptive passive vibration control, Journal of Sound and Vibration 189(5): 565-585.

Fuller, C. R.; Elliott, S. J.; Nelson, P. A. 1996. Active control of vibration. London: Academic Press.

Fundamentals of Vibration Isolation. 2009 [interaktyvus], [žiūrèta 2012-01-30]. Prieiga per internetą: <http://www.cvimellesgriot.com/products/Documents/TechnicalGuide/ Fundamentals-Vibration-Isolation.pdf $>$. 
Gican, V.; Augustaitis, V. K. 2010. Poligrafiniu mechatroniniu sistemu modeliavimas. Vilnius: Technika. 261p.

Giniotis, V.; Grattan, K. T. V.; Rybokas, M.; Kulvietienė, R. 2004. Uncertainty and inderterminacy of measurement data, Measurement 36: 195-202.

Gurecki, V. V. 1971. Ob optimalnich parametrob sistem amortizacini pri stacionarnych slučainych bozdeistvii. Mašinostroenie 5: 23-28.

Gurecki, V. V.; Mazin L. S. 1970. Ob optimalnoi omortizacii uprūgix tel, Mašinostroenie 3: 17-22.

Hamid, S. 2008. Vibration isolation in cleanrooms, Controlled environments, p. 1-3.

Harris, C. M. 1987. Shock and vibration handbook. McGRAW-HILL.

Hensly, J. M.; Achim, P.; Chu, S. 1999. Active low frequency vertical vibration isolation, Review of Schientific Instruments 70(6).

Isermann, R. 1997. Supervision, fault-detection and fault-diagnosis methods - Advanced methods and applications, XIV IMEKO World Congress New Measurements - Challenges and Visions, Finland, Tampere, 1(I): 1-28.

ISO 2041-:2009 Vibration and shock - Vocabulary.

Yang, J. N.; Wu, J. C.; Reinhorn, A. M.; Riley, M. 1996. Control of sliding-isolated buildings using sliding-mode control, J. Struct. Eng., ASCE 122: 179-186.

Yoshida, K.; Fujio, T. 2000. Semi-active base isolation for a building structure, International Journal of Computer Applications in Technology 13(1-2): 52-58.

Jalili, N. 2002. A comparative study and analysis of semi-active vibration-control systems, Journal of Vibration and Acoustics 124: 593-605.

Johnson, E. A.; Ramallo, J. C.; Spencer B. F. Jr.; Sain, M. K. 1999. Intiligent base isolation systems, in Proc. second World conf. Struct. Control, Kyoto, Japan, vol. 1, 367376.

Karnopp, D. 1989. Permanent-magnet linear motors used as variable mechanical dampers for vehicle suspensions, Vehicle System Dynamics 18(4): 187-200.

Karnopp, D. C. 1973. Active and passive isolation of random vibration, in J. C. Snowdon, E. E. Ungar (Eds.). Isolation of Mechanical Vibration, Impact and Noise. Bolt Beranek and Newman Inc: Cincinnati, Ohio, 64-86.

Karnopp, D. C. 1990. Design principles for vibration control systems using semi- active dampers, ASME Journal of Dynamic Systems, Measurement and Control 112: 448-455.

Karnopp, D. C. 1995. Active and semi-active vibration isolation, ASME Journal of Vibration and Acoustics, Special 50th Anniversary Design Issue 117: 177-185.

Karnopp, D. C.; Crosby, M. J.; Harwood, R. A. 1974. Vibration control using semiactive force generators, ASME Journal of Engineering for Industry 96(2): 619-626.

Kildišas, V.; Tekorius, T. 2003. Procesu valdymo uždaviniu sprendimas taikant MATLAB sistemq. Kaunas: Technologija. 
Kožešnik, J. 1961. Dinamika mašin. Moskva: Mašgiz, 166-168.

Krasnicki, E. J. 1980. Comparison of analytical and experimental results for a semiactive vibration isolator, Shock and Vibration Bulletin 50: 69-76.

Krasnicki, E. J. 1980. The experimental performance of an "on-off" active damper, in Proceedings of the 51st Shock and Vibration Symposium. San Diego, USA

Liu, Y.; Waters, T. P.; Brennan, M. J. 2005. A comparison of semi-active damping control strategies for vibration isolation of harmonic disturbances, Journal of Sound and Vibration 280(1): 21-39.

Luo Jun; Wu Caizhang. 1997. Ultra-low frequency active vertical vibration isolation system, Science in China 40(11): 132-139.

Makris, N. 1997. Rigidity-plasticity-viscosity:Can electrorheological dampers protect base-isolated structures from near-source ground motions, Earthquake Engng. Struct. Dyn. 26: 571-591.

McMahon, J. 2009. Gaining popularity as the need for refined imaging with laser/optical system increases.

McMahon, J. 2009. Negative stiffness a big positive for vibration isolation. Mechanical.

McMahon, J. 2011. Improving Nano-Scale Imaging of Integrated Micro-Raman/AFM Systems Using Negative-Stiffness Vibration Isolation. Nanotechnology Now Online.

McMahon, J.; Kushin, D. 2009. Shake, rattle, roll no more. Motion system design.

Mead, D. J. 1999. Passive vibration control. London: John Wiley \& Sons Ltd.

Ming-Chang Shih; Teng-Yen Wang. 2008. Active control of electro- rheological fluid embedded pneumatic vibration isolator, Integrated Computer-Aided Engineering 15: 267-276.

Naim, F.; Kelly, J. M. 1999. Design of seismic isolated structures: From theory to practice. John Wiley and Sons Ltd, Chichester, England.

Nakazava, H. 1994. Principles of Precision Engineering. Oxford University Press.

Nashif, A. D., Johnes, D. I. G.; Henderson, J. P. 1985. Vibration damping. John Wiley and Sons, New York Chichester Brisbane Toronto Singapore ISBN 0-471-867721,440 .

Nelson, F. C. 1994. Vibration isolation: a review, I. sinusoidal and randomexcitations, Shock and Vibration 1(5): 485-493.

Nelson, P. G. 2003. Understanding and Measuring Noise Sources in Vibration Isolation Systems. Technical Manufacturing Corporation.

Oueslati, F.; Sankar, S. 1994. A class of semi-active suspension schemes for vehicle vibration control, Journal of Sound and Vibration 172(3): 391-411.

Pan, G., et al. 1999. Adaptive vibration control policy of semi-active "on-off damper, in Proceedings of Pioneering International Symposium on Motion and Vibration Control in Mechatronics. Tokyo. 
Pan, G.; Matsuhisa, H.; Honda, Y. 2000. Smoothing of on-off damper force with the variable damping coefficient, Transaction of Japanese Society of Mechanical Engenderers (C) 66(644): 1158-1164.

Platus, D. L. 1991. Negative-Stiffness-Mechanism Vibration Isolation Systems, SPIE Vibration Control in Microelectronics, Optics, and Metrology 1619: 44-54.

Platus, D. L. 9931. Smoothing out Bad Vibes, Machine Design, February 26, p.123.

Quinn, T. J. 1994. Mise en Pratique of the Definition of the Metre, Metrologia 30: 523541.

Ramallo, J. C.; Johnson, E. A.; Spencer, B. F. Jr.; Sain, M. K. 2000. “Smart” base isolation systems. ASCE 2000 structures congress: Advenced Technology in Structural Engineering. Philadelphia, Pennsylvania, May 8-10, CD-ROM Proceedings, paper No 40492005-002.

Rao, S. S. 1995. Mechanical Vibrations. Third Edition. Addison-Wesley Publishing Company.

Sciulli, D. 1997. Dynamics and control for vibration isolation design, in Department of Engineering Mechanics. Virginia Polytechnic Institute and State University: Blacksburg, Virginia.

Symans, M. D.; Constantinou, M. C. 1999. Semi-active control systems for seismic protection of structures: a state-of-the-art review, Engineering Structures 21(6): 469 487.

Skiner, R. I.; Robinson, W. H.; McVerry, G. H. 1993. An introduction to seismic isolation. John Wiley and Sons Ltd. Chichester, England.

Snyder, S.; Hansen, C. H. 1997. Active Control of Noise and Vibration. Spon Press.

Snowdon, J. C. 1968. Vibration and Shock in Damped Mechanical Systems. John Wiley \& Sons.

Soong, T. T. 1990. Active Structural Control: Theory and Practice. New York: John Wiley \& Sons.

Sorokin, E. S. 1976. Chastotnonezavisimoje vnutrenneje trenije v materialakh I hipoteza voigta, Stroit. Mech. I raschiot soorusenij 2.

Spanos, J.; Rahman, Z.; Flotow, A. von. 1993. Activevibration isolation on an experimental flexible structure, Smart Structure and Intelligent Systeme, Albuquerque, 1917-60: 201-215.

Spencer, Jr. B. F., Johnson, E. A.; Ramallo, J. C. 1999. Smart isolation for seismic control, in Proceedings of the pioneering international symposium on motion and vibration control in mechatronics. Waseda University, Tokyo, Japan, April 6-7, 37-60.

Stöbener, Uwe. 2009. Active Vibration Isolation For Highly Sensitive Measurement Equipment.Controlled Environments, 1-5. 
Sun Hongling, Zhang Kun, Chen Haibo, Zhang Peiqiang, 2007. Improved Active Vibration Isolation Systems", Tsinghua science and technology 12(5).

Takeshi, M.; Toumiy, T; Takasaki, M. 2003. Vibration isolation system using negative stiffness, JSME international Journal 46(3): 7-15.

Thorlabs [interaktyvus] [žiūrèta 2012-05-10]. Prieiga per interneta: <http://www. thorlabs.com/newgrouppage9.cfm?objectgroup_id=1095>.

Vekteris, V.; Kasparaitis, A.; Kaušinis, S.; Kanapėnas, R. 2000. Matavimu teorija ir praktika. Vilnius: Žiburio 1-kla.

Vibration isolation is key to accuracy. A Minus K Technology product story. Ed. by the Engineeringtalk Editorial Team Nov 7, 2006

Vijayan, V.; Karthikeyan, T. 2009. Design and Analysis of Compliant Mechanism for Active Vibration Isolation Using FEA Technique, International Journal of Recent Trends in Engineering 1(5).

Voigt, W. 1892. Ann. Physs. Bd. 47, s. 671

Volkovas, V.; Eidukevičiūtè, M. 2004. Uncertainty in vibromonitoring systems of rotating machinery, in Vibroengineering: Proceedings of 5th International Conference, October 14-15, 111-113. ISSN 1392-8716.

Weise, K.; Wöger, W. A Bayesian. 1993. Theory of Measurement Uncertainty, Measurement Science Technology 4 (1): 1-11.

Zhang, Y. F.; Iwan, W. D. 2002. Active interaction control of civil structures. Part 1: SDOF systems, Earthquake Engineering \& Structural Dynamics 31(1): 161-178.

Zotov, A. N. 2005. The vibration absorber with the working quazinull rigidity range, Machin and Apparatus 3: 265-272.

Zotov, A. N. 2005. Vibroizoliatori s kvazinulevoi žoskostjų, Neftegazovoje delo 1: $1-11$.

Zuo Lei, Jean-Jacques, E. 2011. Slotine and Samir Nayfeh. Experimental Study of a Novel Adaptive Controller for Active Vibration Isolation. LIGO-P 040010-00-z. 


\section{Autoriaus mokslinių publikaciju disertacijos tema sąrašas}

\section{Straipsniai recenzuojamuose mokslo žurnaluose}

Kilikevičius, A.; Jurevičius, M; Berba, M. 2010. Research of dynamics of a vibration izoliation platform, Journal of Vibroengineering 12(3): 361-367. ISSN 1392-8716 (ISI Web of Science).

Jurevičius, M.; Kilikevičius A.; Berba, M. 2011. Impact of external excistations on the dynamic properties of negatyve stiffness vibration isoliation table, Journal of Vibroengineering 13(2): 352-357. ISSN 1392-8716 (ISI Web of Science).

\section{Straipsniai kituose leidiniuose}

Meškelyte, V.; Jurevičius, M.; Berba, M. 2011. Neigiamo standumo vibroizoliacinio staliuko „Minus K 500BM-1“ tyrimas, Mokslas - Lietuvos ateitis 3(6): 5660. ISSN 2029-2341.

Berba, M.; Jurevičius, M. 2012. Research of dynamic properties of a complex vibration isoliation system, in The $7^{\text {th }}$ International Symposium "Machine and Industrial Design in Mechanical Eengineering”: selected papers, Vol. 3, May 24-26, 2012 Balatonfured, Hungary, 381-384. ISBN 978-86-7892-399-9. 


\section{Patentas}

Berba, M.; Baranov, A.; Jurevičius, M. 2012. Mechanine kvazinulinio standžio vibroizoliaciné sistema. Lietuvos patentas LT 5883. 


\section{Priedai}

Priedai pateikti skaitmeninejje laikmenoje

A priedas. Kvazinulinio standžio virpesių izoliavimo sistemos virpesių matavimu rezultatai

B priedas. Patentas LT 5883 „Mechaninè kvazinulinio standžio vibroizoliacinè sistema“"

C priedas. Sudètinès sistemos virpesių matavimų rezultatai 
Michail BERBA

PASYVIUUJU ŽEMOJO DAŽNIO VIRPESIỤ IZOLIAVIMO SISTEMUৃ TYRIMAS

Daktaro disertacija

Technologijos mokslai, mechanikos inžinerija (09T)

Michail BERBA

RESEARCH OF PASSIVE LOW-FREQUENCY VIBRATION ISOLATION SYSTEMS

Doctoral Dissertation

Technological Sciences, Mechanical Engineering (09T)

201212 21. 11,5 sp. I. Tiražas 20 egz.

Vilniaus Gedimino technikos universiteto

leidykla „Technika“,

Saulètekio al. 11, 10223 Vilnius,

http://leidykla.vgtu.lt

Spausdino UAB "Ciklonas"

J. Jasinskio g. 15, 01111 Vilnius 